RAINFALL, RUNOFF, AND WATER-QUALITY DATA FOR THE URBAN STORM-WATER PROGRAM IN THE ALBUQUERQUE, NEW MEXICO, METROPOLITAN AREA, WATER YEAR 2004

U.S. DEPARTMENT OF THE INTERIOR U.S. GEOLOGICAL SURVEY

Open-File Report 2006-1105

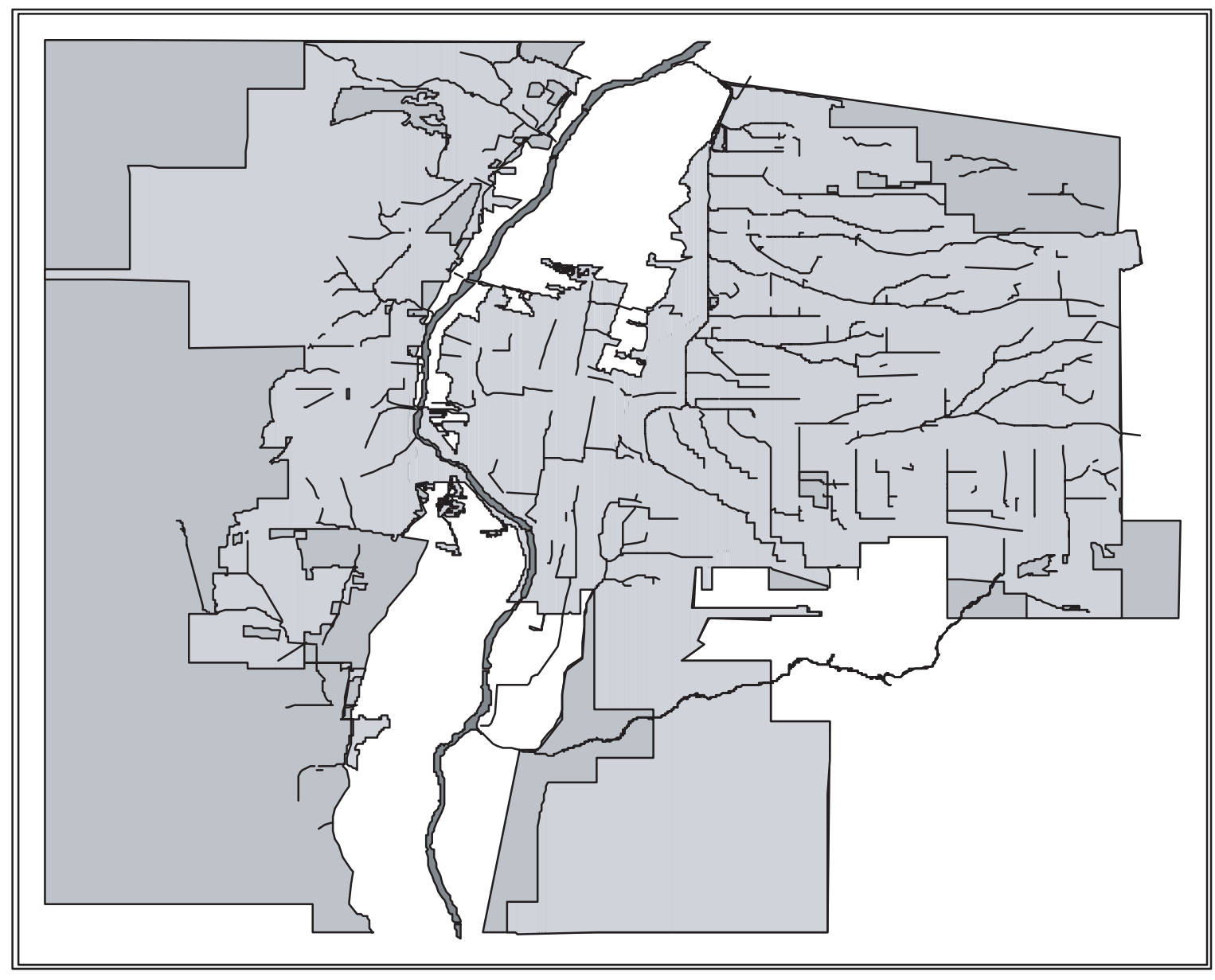

Prepared in cooperation with the ALBUQUERQUE METROPOLITAN ARROYO FLOOD CONTROL AUTHORITY and the CITY OF ALBUQUERQUE 
Blank Page 


\section{Rainfall, Runoff, and Water-Quality Data for the Urban Storm-Water Program in the Albuquerque, New Mexico, Metropolitan Area, Water Year 2004}

By Todd Kelly, Orlando Romero, and Mike Jimenez

Open-File Report 2006-1105

Prepared in cooperation with the

ALBUQUEROUE METROPOLITAN ARROYO

FLOOD CONTROL AUTHORITY

and the

CITY OF ALBUQUERQUE 


\section{U.S. Department of the Interior P. Lynn Scarlett, Acting Secretary}

\section{U.S. Geological Survey \\ P. Patrick Leahy, Acting Director}

U.S. Geological Survey, Reston, Virginia: 2006

For sale by U.S. Geological Survey, Information Services

Box 25286, Denver Federal Center

Denver, CO 80225

For more information about the USGS and its products:

Telephone: 1-888-ASK-USGS

World Wide Web: http://www.usgs.gov/

Any use of trade, product, or firm names in this publication is for descriptive purposes only and does not imply endorsement by the U.S. Government.

Although this report is in the public domain, permission must be secured from the individual copyright owners to reproduce any copyrighted materials contained within this report. 


\section{CONTENTS}

Abstract

Introduction

Purpose and Scope

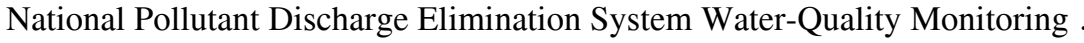

Rainfall and Runoff Data Collection

Annual Daily Mean Flow Hydrograph of the North Floodway Channel and the Rio Grande at Albuquerque

Gaging Stations

References Cited

Runoff Data Summary, Water Year 2004

Surface-Water Runoff Data for Water Year 2004

08329700 Campus Wash at Albuquerque, New Mexico

08329720 Embudo Arroyo at Albuquerque, New Mexico

08329835 North Floodway Channel at Albuquerque, New Mexico

08329840 Hahn Arroyo at Albuquerque, New Mexico

08329868 Bear Canyon Arroyo Near Albuquerque, New Mexico

08329870 Bear Arroyo at Jefferson St. at Albuquerque, New Mexico

08329882 Pino Arroyo at Jefferson St. at Albuquerque, New Mexico

08329888 La Cueva Arroyo Tributary (Upper) at Albuquerque, New Mexico

08329900 North Floodway Channel Near Alameda, New Mexico

08329911 North Camino Arroyo at Sunset Hills in Albuquerque, New Mexico ....

08329926 Calabacillas Arroyo Below Coors Boulevard at Albuquerque, New Mexico

08329935 Arroyo 19A at Albuquerque, New Mexico

083299375 Mariposa Diversion of San Antonio Arroyo at Albuquerque, New Mexico ...............................

08329938 Ladera Arroyo at Albuquerque, New Mexico

08330200 San Jose Drain at Woodward Road at Albuquerque, New Mexico .....

08330540 Tramway Floodway Channel at Albuquerque, New Mexico .....

08330600 Tijeras arroyo Near Albuquerque, New Mexico

08330775 South Diversion Channel Above Tijeras Arroyo Near Albuquerque, New Mexico

08331118 Amole Del Norte Channel at Albuquerque, New Mexico

Rainfall Data Summary, Water Year 2004

Precipitation for Water Year 2004

Precipitation Totals

Comparison to Historical Data ......

References Cited

08329880 Academy Acres Drain Rain Gage at Albuquerque, New Mexico

350448106390230, Albuquerque City Hall Rain Gage at Albuquerque, New Mexico

350627106364630, AMAFCA Headquarters Rain Gage Nr. Albuquerque, New Mexico

08329935, Arroyo 19A Rain Gage at Albuquerque, New Mexico

350859106274330, Bear Canyon Rain Gage in Albuquerque, New Mexico

350340106385230, Bernalillo County Building Rain Gage Near Albuquerque, New Mexico

350713106314230, Borland Rain Gage in Albuquerque, New Mexico

08329700, Campus Wash Rain Gage at Albuquerque, New Mexico

350400106465630, Crown Towers at Nine Mile Hill Rain Gage at Albuquerque, New Mexico .......................

350954106282330, Elena Gallegos Picnic Area Rain Gage at Albuquerque, New Mexico ................................

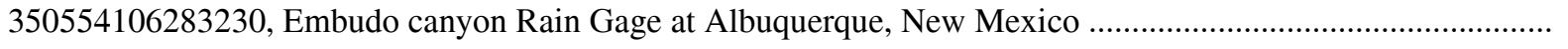

350348106453230, Emergency Dispatch Building Rain Gage at Albuquerque, New Mexico ............................. 91

350357106443030, Fire Station \#14 Rain Gage in Albuquerque, New Mexico ................................................ 92

350756106305430, Fire Station \#16 Rain Gage in Albuquerque, New Mexico ............................................. 93

08329840, Hahn Arroyo Rain Gage in Albuquerque, New Mexico ............................................................ 94

350310106320930, Kirtland Air Force Base Rain Gage at Eubank Gate, Albuquerque, New Mexico ................ 95

350912106455630, La Boca Negra Rain Gage Near Albuquerque, New Mexico .......................................... 96 
08329890, La Cueva Arroyo Tributary Rain Gage Near Albuquerque, New Mexico ........................................ 97

08329938, Ladera Arroyo Rain Gage at Albuquerque, New Mexico ................................................................ 98

350310106434930, Leavitt Pump Station Rain Gage at Albuquerque, New Mexico ............................................ 99

350722106325030, Leonard Rain Gage in Albuquerque, New Mexico ........................................................... 100

350540106333230, Love Pump Station Rain Gage at Albuquerque, New Mexico .............................................. 101

08329914, North Camino Arroyo Tributary at Wyoming Boulevard Rain Gage at Albuquerque, New Mexico .... 102

08329835, North Floodway Channel Rain Gage at Albuquerque, New Mexico .................................................. 103

08329900, North Floodway Channel Rain Gage Near Alameda, Albuquerque, New Mexico ............................... 104

350417106363330, Orlando Romero Rain Gage in Albuquerque, New Mexico ................................................ 105

350939106430930, Petroglyphs Park Rain Gage at Albuquerque, New Mexico ................................................. 106

351631106481230, Rio Rancho Well \#13 Rain Gage, Rio Rancho, New Mexico ............................................. 107

08329838, South Fork Hahn Arroyo Rain Gage in Albuquerque, New Mexico ................................................... 108

08330200, San Jose Drain Rain Gage at Albuquerque, New Mexico ................................................................. 109

351216106421330, Swinburn Dam Rain Gage at Paradise Hills, New Mexico .................................................. 110

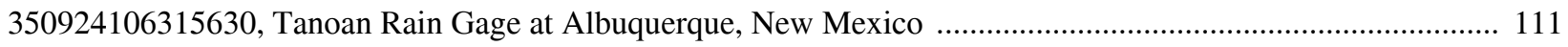

08329936, Taylor Ranch Drain Rain Gage at Albuquerque, New Mexico ...................................................... 112

350755106325830, Thomas Pump Station Rain Gage at Albuquerque, New Mexico ....................................... 113

08330580, Tijeras Arroyo at Montessa Park Rain Gage near Albuquerque, New Mexico ..................................... 114

351516106431430, Tm Kelly Rain Gage at Rio Rancho, New Mexico .......................................................... 115

08330540, Tramway Floodway Channel Rain Gage at Albuquerque, New Mexico ........................................... 116

350748106345830, USGS Office Rain Gage at Albuquerque, New Mexico ................................................... 117

351023106313930, Walker Pump Station Rain Gage at Albuquerque, New Mexico ............................................. 118

350119106394630, Wastewater Treatment Plant Rain Gage at Albuquerque, New Mexico ................................. 119

\section{FIGURES}

1. Map showing U.S. Geological Survey data-collection sites for 2004 Albuquerque Urban Runoff Program ...... 3

2. Photographs showing (A) La Cueva rain gage, (B) recorder next to rain gage, and (C) view inside of

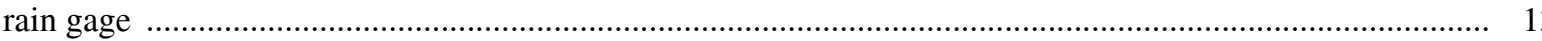

3. Hydrographs showing discharge at the North Floodway Channel near Alameda in comparision to discahrge at the Rio Grande at Albuquerque streamflow-gaging stations .................................................

4. Graphs showing precipitation totals for water year 2004 in comparison to totals for July through September 2004 at 39 U.S. Geological Survey rain gages 74

5. Comparison of total annual precipitation for water year 2004 to average historical total annual precipitation at selected U.S. Geological Survey rain-gage sites ................................................................. 76

6-9. Monthly precipitation at selected U.S. Geological Survey rain-gage sites:

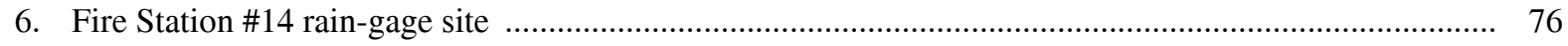

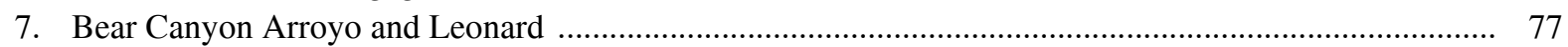

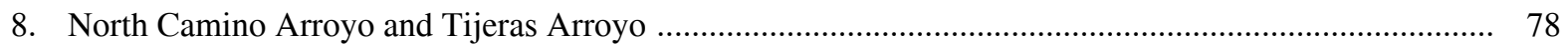

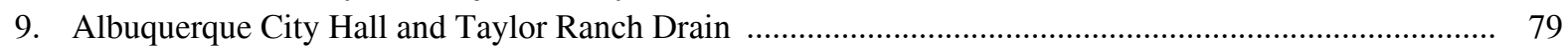

\section{TABLES}

1. Map locations and station identification numbers

2. Albuquerque Storm-Water Sampling Program - National Pollution Discharge Elimination System concentrations of 12 priority water-quality constituents plus bacteria for 2004 ............................................ 7

3. Period of record of digitally archived unit values for urban streamflow-gaging stations ................................. 11

4. Period of record of digitally archived unit values for urban rain-gage sites .................................................. 12

5. Maximum flood peak stage and discharge for water year 2004 and for the period of record ........................... 18 
CONVERSION FACTORS, DATUMS, AND ABBREVIATIONS

\begin{tabular}{rll}
\hline Multiply & By & To obtain \\
\hline cubic foot per second $\left(\mathrm{ft}^{3} / \mathrm{s}\right)$ & & \\
foot $(\mathrm{ft})$ & 0.02832 & cubic meter per second $\left(\mathrm{m}^{3} / \mathrm{s}\right)$ \\
inch $(\mathrm{in})$. & 0.3048 & meter $(\mathrm{m})$ \\
mile $(\mathrm{mi})$ & 2.54 & centimeter $(\mathrm{cm})$ \\
kilometer $(\mathrm{km})$ \\
square mile $\left(\mathrm{mi}^{2}\right)$ & 1.609 & hectare $($ ha) \\
square mile $\left(\mathrm{mi}^{2}\right)$ & 259.0 & square kilometer $\left(\mathrm{km}^{2}\right)$ \\
& 2.590 & \\
\hline
\end{tabular}

Vertical coordinate information is referenced to the North American Vertical Datum of 1988 (NAVD 88).

Vertical coordinate information is referenced to the National Geodetic Vertical Datum of 1929 (NGVD 29). 
Blank Page 


\title{
RAINFALL, RUNOFF, AND WATER-QUALITY DATA FOR THE URBAN STORM-WATER PROGRAM IN THE ALBUQUERQUE, NEW MEXICO, METROPOLITAN AREA, WATER YEAR 2004
}

\author{
By Todd Kelly, Orlando Romero, and Mike Jimenez
}

\begin{abstract}
Urbanization has dramatically increased precipitation runoff to the system of drainage channels and natural stream channels in the Albuquerque, New Mexico, metropolitan area. Rainfall and runoff data are important for planning and designing future storm-water conveyance channels in newly developing areas. Storm-water quality also is monitored in accordance with the National Pollutant Discharge Elimination System mandated by the U.S. Environmental Protection Agency. The Albuquerque Metropolitan Arroyo Flood Control Authority, the City of Albuquerque, and the U.S. Geological Survey began a cooperative program to collect hydrologic data to assist in assessing the quality and quantity of surface-water resources in the Albuquerque area. This report presents water-quality, streamflow, and rainfall data collected from October 1, 2003, to September 30, 2004 (water year 2004). Also provided is a station analysis for each of the 18 streamflow-gaging sites and 39 rainfall-gaging sites, which includes a description of monitoring equipment, problems associated with data collection during the year, and other information used to compute streamflow discharges or rainfall records. A hydrographic comparison shows the effects that the largest drainage channel in the metropolitan area, the North Floodway Channel, has on total flow in the Rio Grande.
\end{abstract}

\section{INTRODUCTION}

The system of drainage channels and natural stream channels in the Albuquerque, New Mexico, metropolitan area is a source of concern because of potential local flooding and waterquality problems. Rapid urbanization since 1970 has dramatically increased precipitation runoff to these channels, which in many instances returns flow to the Rio Grande. As an important element of the City of Albuquerque's water resources management, accurate hydrologic data are needed for designing storm drainage and addressing storm-water-quality regulations established by the U.S. Environmental Protection Agency's National Pollutant Discharge Elimination System (NPDES). The NPDES was initiated to monitor the quality of storm-water runoff that flows into natural bodies of water from metropolitan areas. To meet regulatory requirements, long-term streamflow data can be analyzed in conjunction with water-quality sampling to compute constituent loading over time. Rainfall and runoff data for watersheds of various land uses are important for planning and designing future storm-water conveyance channels in newly developing areas of Albuquerque. In addition, accurate hydrologic data are necessary to calibrate 
computer models that aid local engineers and city planners in the estimation of storm-water runoff.

With these needs in mind, the U.S. Geological Survey (USGS), in cooperation with the Albuquerque Metropolitan Arroyo Flood Control Authority (AMAFCA) and the City of Albuquerque, began a study in 1976 to collect hydrologic data to help assess surface-water resources in the Albuquerque area and to determine long-term trends. The information gained will better help AMAFCA and the City to manage and administer water resources. The program is reviewed and revised annually to meet AMAFCA's and the City's needs. Data collected also support digital modeling programs conducted by AMAFCA. Flood-frequency analyses of selected watersheds can be completed when sufficient data are available.

Historically, daily mean discharges at selected streamflow-gaging stations are published in the USGS annual Water-Data Report, but prior to the water year 2001 summary report (Kelly and Romero, 2003), no annual data summary report had been devoted exclusively to this study. Two previous reports (Fischer and others, 1984; Metzker and others, 1993) summarized rainfall and runoff data for selected storms during 1976-83 and 1984-88. Daily rainfall totals and intensities as well as annual water-quality sampling results are not included in the annual WaterData Report but are provided to the cooperators on request. Instantaneous maximum stages for secondary peaks and all gage-height or rainfall values recorded at 5-minute intervals are available from the USGS database. The purpose of this cooperative program is to obtain rainfall and surface-water (water quality and streamflow) data for an assessment of water resources (quantity and quality), for determination of long-term trends, and for water management and administration purposes.

\section{Purpose and Scope}

This report presents water-quality, streamflow, and rainfall data collected from October 1 , 2003, to September 30, 2004 (water year 2004). The report provides a station analysis for each data-collection site, which includes a description of monitoring equipment, problems associated with data collection during the year, and other information used to compute streamflow discharges or rainfall records. A daily values table showing daily mean discharge for gaging stations or daily total rainfall recorded at rain gages accompanies each station analysis. Detailed site descriptions, drainage-basin areas, and periods of record are also included in the daily values tables.

The locations of the current network of gaging stations, rain gages, and water-quality sampling sites in the Albuquerque area are shown in figure 1. Eleven of the 12 stations designated as water-quality sampling sites in figure 1 also have recording streamflow gages. Barelas pump station (\#52) does not record flow data. Information about the sites is listed in table 1.

\section{National Pollutant Discharge Elimination System Water-Quality Monitoring}

The water-quality sampling program began in fiscal year 1992 under a separate cooperative agreement between AMAFCA, the City of Albuquerque, and the USGS. Surfacewater-quality samples were collected at five gaging stations and two background sites in 1992. 


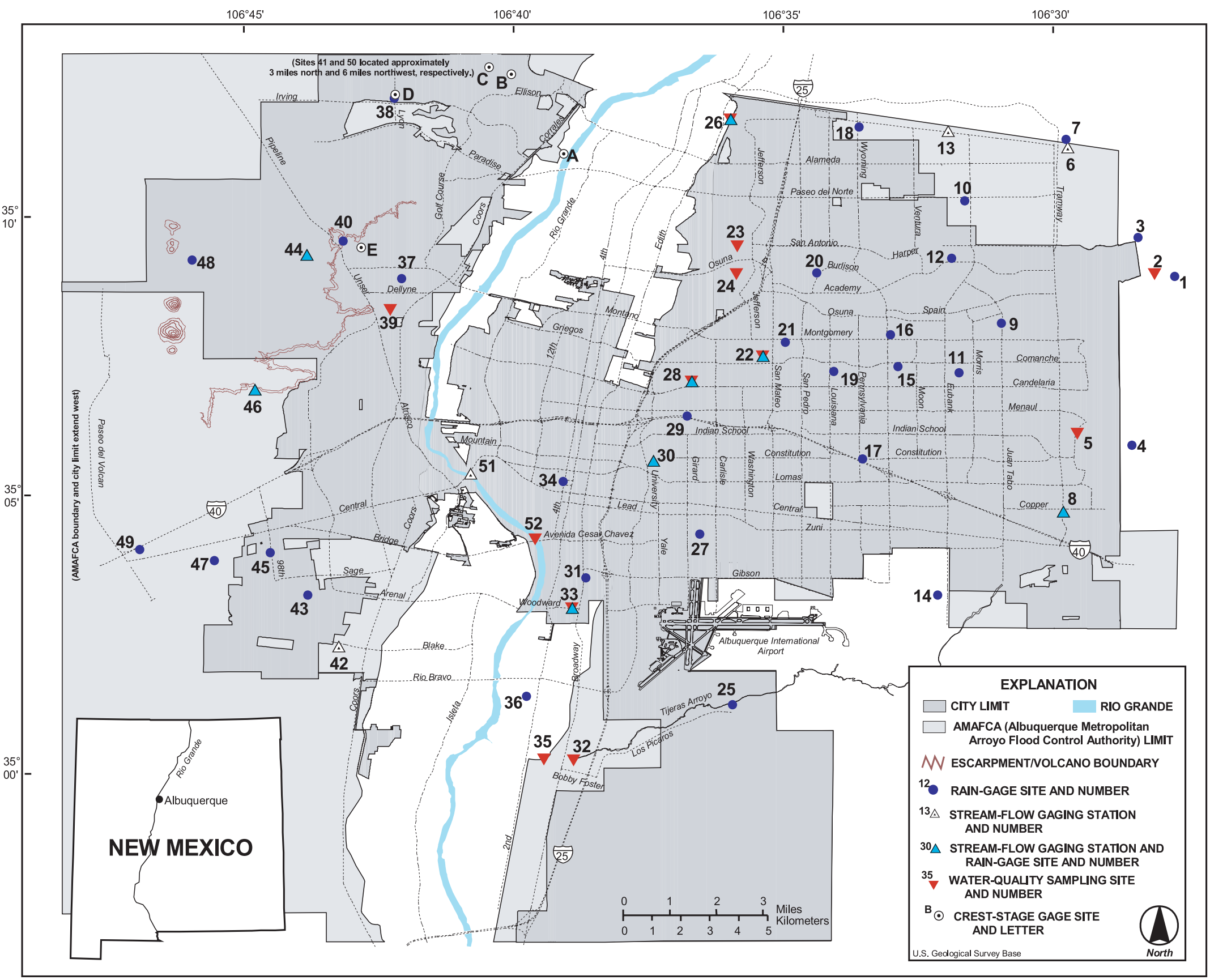

Figure 1. U.S. Geological Survey data-collection sites for 2004 Albuquerque Urban Runoff Program. Location numbers are in table 1. 
Table 1. Map locations and station identification numbers

\begin{tabular}{|c|c|c|c|c|c|}
\hline $\begin{array}{c}\text { Site } \\
\text { ID } \\
\text { (fig. 1) }\end{array}$ & Name & $\begin{array}{c}\text { U.S. Geological } \\
\text { Survey station } \\
\text { number }\end{array}$ & $\begin{array}{l}\text { Latitude } \\
\text { (degrees) }\end{array}$ & $\begin{array}{c}\text { Longitude } \\
\text { (degrees) }\end{array}$ & $\begin{array}{l}\text { Streamflow- } \\
\text { gaging } \\
\text { station }\end{array}$ \\
\hline 1 & Bear Canyon Rain Gage & 350859106274330 & 35.1500 & -106.4625 & $\mathrm{G} 30$ \\
\hline 2 & Bear Canyon Arroyo nr. Albq. & 08329868 & 35.1508 & -106.4686 & \\
\hline 3 & Elena Gallegos Picnic Area Rain Gage & 350954106282330 & 35.1619 & -106.4739 & G39 \\
\hline 4 & Embudo Canyon Rain Gage & 350554106283230 & 35.0986 & -106.4758 & G44 \\
\hline 5 & Embudo Arroyo @ Albq. & 08329720 & 35.1022 & -106.4925 & \\
\hline 6 & La Cueva Arroyo Trib. (upper) & 08329888 & 35.1894 & -106.4956 & \\
\hline 7 & La Cueva Arroyo Trib. Rain Gage & 08329890 & 35.1919 & -106.4961 & G9 \\
\hline 8 & Tramway Floodway Channel & 08330540 & 35.0783 & -106.4969 & G53 \\
\hline 9 & Fire Station \#16 Rain Gage & 350756106305430 & 35.1358 & -106.5161 & G1 \\
\hline 10 & Walker Pump Rain Gage & 351023106313930 & 35.1731 & -106.5274 & G55 \\
\hline 11 & Borland Rain Gage & 350713106314230 & 35.1206 & -106.5292 & G23 \\
\hline 12 & Tanoan Rain Gage & 350924106315630 & 35.1556 & -106.5314 & G34 \\
\hline 13 & N. Camino Arroyo at Sunset Hills & 08329911 & 35.1944 & -106.5325 & \\
\hline 14 & Kirtland AFB Rain Gage & 350310106320930 & 35.0528 & -106.5358 & G50 \\
\hline 15 & Leonard Rain Gage & 350722106325030 & 35.1225 & -106.5481 & $\mathrm{G} 22$ \\
\hline 16 & Thomas Pump Rain Gage & 350755106325830 & 35.1322 & -106.5503 & G36 \\
\hline 17 & Love Pump Rain Gage & 350540106333230 & 35.0944 & -106.5589 & G56 \\
\hline 18 & N. Camino Arroyo Trib. Rain Gage & 08329914 & 35.1956 & -106.56 & G11 \\
\hline 19 & South Fork Hahn Arroyo Rain Gage & 08329838 & 35.1211 & -106.5678 & G4 \\
\hline 20 & Academy Acres Drain Rain Gage & 08329880 & 35.1511 & -106.5731 & G8 \\
\hline 21 & USGS Office Rain Gage & 350748106345830 & 35.1300 & -106.5828 & G46 \\
\hline 22 & Hahn Arroyo@ Albq. & 08329840 & 35.1258 & -106.5897 & G5 \\
\hline 23 & Pino Arroyo @ Jefferson St. & 08329882 & 35.1594 & -106.5975 & \\
\hline 24 & Bear Arroyo @ Jefferson St. & 08329870 & 35.1508 & -106.5978 & \\
\hline 25 & Tijeras Arroyo Rain Gage & 08330580 & 35.0194 & -106.5992 & G32 \\
\hline 26 & N. Floodway Channel near Alameda & 08329900 & 35.1981 & -106.5997 & G40 \\
\hline 27 & Orlando Romero Rain Gage & 350417106363330 & 35.0714 & -106.6092 & G54 \\
\hline 28 & North Floodway Channel @ Albq. & 08329835 & 35.1181 & -106.6117 & G45 \\
\hline 29 & AMAFCA Headqtrs. Rain Gage & 350627106364630 & 35.1075 & -106.6131 & G43 \\
\hline 30 & Campus Wash@Albq. & 08329700 & 35.0939 & -106.6236 & G28 \\
\hline 31 & Bernalillo County Bldg. Rain Gage & 350340106385230 & 35.0581 & -106.6444 & G42 \\
\hline 32 & Tijeras Arroyo near Albq. & 08330600 & 35.0025 & -106.6481 & \\
\hline 33 & San Jose Drain@Woodward Road & 08330200 & 35.0489 & -106.6486 & $\mathrm{G} 38$ \\
\hline 34 & Albuquerque City Hall Rain Gage & 350448106390230 & 35.0875 & -106.6514 & G41 \\
\hline 35 & S. Diversion Channel abv. Tijeras Arr. & 08330775 & 35.0028 & -106.6572 & \\
\hline 36 & Wastewater Treatment Plant RG & 350119106394630 & 35.0219 & -106.6628 & G51 \\
\hline 37 & Taylor Ranch Drain Rain Gage & 08329936 & 35.1494 & -106.7014 & G15 \\
\hline 38 & Swinburn Dam Rain Gage & 351216106421330 & 35.2044 & -106.7036 & G49 \\
\hline 39 & Mariposa Div. of San Antonio Arroyo & 083299375 & 35.1400 & -106.7047 & \\
\hline 40 & Petroglyphs Park Rain Gage & 350939106430930 & 35.1608 & -106.7194 & G37 \\
\hline
\end{tabular}


Table 1. Map locations and station identification numbers--Concluded.

\begin{tabular}{cllrcc}
\hline $\begin{array}{c}\text { Site } \\
\text { ID } \\
\text { (fig. 1) }\end{array}$ & \multicolumn{1}{c}{ Name } & $\begin{array}{c}\text { U.S. Geological } \\
\text { Survey station } \\
\text { number }\end{array}$ & $\begin{array}{c}\text { Latitude } \\
\text { (degrees) }\end{array}$ & $\begin{array}{c}\text { Longitude } \\
\text { (degrees) }\end{array}$ & $\begin{array}{c}\text { Streamflow- } \\
\text { gaging } \\
\text { station }\end{array}$ \\
\hline 41 & Todd Kelly Rain Gage & 351516106431430 & 35.2544 & -106.7206 & G57 \\
42 & Amole del Norte Channel @ Albq. & 08331118 & 35.0372 & -106.7208 & \\
43 & Leavitt Pump Rain Gage & 350310106434930 & 35.0528 & -106.7303 & G47 \\
44 & Arroyo 19A @ Albq. & 08329935 & 35.1567 & -106.7306 & G13 \\
45 & Fire Station \#14 Rain Gage & 350357106443030 & 35.0658 & -106.7419 & G29 \\
& & & & \\
46 & Ladera Arroyo @ Albq. & 08329938 & 35.1156 & -106.7467 & G16 \\
47 & Emergency Dispatch Bldg. Rain Gage & 350348106453230 & 35.0633 & -106.7592 & G52 \\
48 & La Boca Negra Rain Gage & 350912106455630 & 35.1550 & -106.7661 & G12 \\
49 & Crown Towers Rain Gage & 350400106465630 & 35.0667 & -106.7822 & G48 \\
50 & Rio Rancho Well \#13 & 351631106481230 & 35.2753 & -106.7933 & G58 \\
& & & & \\
51 & Rio Grande at Albuquerque & 08330000 & 35.0835 & -106.6780 & \\
52 & Barelas Pump Station (UR400) & & 35.0700 & -106.6600 & \\
& & 2004 Urban Project Crest-Stage Gages & & \\
A & Calabacillas Arroyo below Coors Blvd. & 08329926 & 35.1875 & -106.6514 & \\
B & 7-Bar Arroyo above Black Arroyo & 083299238 & 35.2117 & -106.6675 & \\
C & Black Arroyo below Golf Course Road & 083299236 & 35.2139 & -106.6744 & \\
D & Calabacillas Arroyo @ Swinburn Dam & 08329921 & 35.2058 & -106.7036 & \\
E & Boca Negra below Petroglyphs Park & 08329937 & 35.1589 & -106.7139 & \\
\hline
\end{tabular}

Since 1994, the sampling program has been included as part of the urban storm-water datacollection program. Water-quality monitoring under the NPDES is now in a phase to better define the quality of storm-water runoff in individual drainage basins. To support this program, existing gaging stations may be moved or a specified drainage basin may be supplemented with new stations to provide the data necessary for constituent-loading computations. Eleven combination streamflow gages and water-quality sampling sites were operational in fiscal year 2004. The water-quality data collected at 10 of these stations during water year 2004, including mean concentrations for 12 priority constituents and bacteria concentrations, are summarized in table 2. Flow was not recorded at the eleventh site, Bear Canyon Arroyo near Albuquerque (08329868), during this time period. Three additional non-recording sites are also listed in the table; Barelas Pump Station, North Floodway Outfall, and the North Pino Arroyo Detention Pond.

A "complete" analysis for the 12 priority constituents is comprised of two types of samples - grab and composite - collected during each storm. A grab sample was collected within 20 minutes after the start of flow. Discrete storm-water samples were collected at intervals ranging from 5 to 20 minutes during the first 3 hours of runoff. The discrete samples were then mixed together; the volume of each discrete sample was added depending on the magnitude of discharge at the time of collection. The greater the discharge at the time of collection, the greater the volume of sample added to the mixture. This type of sample is referred to as a flow-weighted composite sample and represents flow during the first 3 hours of runoff (minus the grab sample). Grab and composite sample discharges are also shown in table 2. 
All "complete analysis" samples were analyzed for trace elements, phenolics, major ions, chemical oxygen demand, biochemical oxygen demand, bacteria, and cyanide by the City of Albuquerque Water Quality Laboratory; nutrients, volatile organic compounds, pesticides, and semivolatile base neutral acids were analyzed by the New Mexico State Laboratory in

Albuquerque. Two additional samples are collected as replicates at two random sites each fiscal year for quality assurance/quality control purposes and shipped to the USGS National Water Quality Laboratory in Denver, Colorado. 
Table 2. Albuquerque Storm-Water Sampling Program - National Pollution Discharge Elimination System concentrations of 12 priority water-quality constituents plus bacteria for 2004.

[NPDES, National Pollutant Discharge Elimination System; $\mathrm{ft}^{3} / \mathrm{s}$, cubic feet per second; $\mathrm{mg} / \mathrm{L}$, milligrams per liter; $\mu \mathrm{g} / \mathrm{L}$, micrograms per liter; cols/100 ml, colonies per 100 milliliters; --, no data; <, less than; mpn, most probable numbers]

\begin{tabular}{|c|c|c|c|c|c|c|c|c|c|}
\hline $\begin{array}{l}\text { Sampling site and } \\
\text { USGS number } \\
\text { (cooperator } \\
\text { number) }\end{array}$ & $\begin{array}{c}\text { Date } \\
\text { sampled }\end{array}$ & $\begin{array}{c}\text { Grab } \\
\text { sample } \\
\text { discharge }^{1} \\
\left(\mathbf{f t}^{3} / \mathbf{s}\right)\end{array}$ & $\begin{array}{c}\text { Composite } \\
\text { sample } \\
\text { discharge }^{2} \\
\left(\mathrm{ft}^{3} / \mathrm{s}\right)\end{array}$ & $\begin{array}{l}\text { Dissolved } \\
\text { solids } \\
(\mathrm{mg} / \mathrm{L})\end{array}$ & $\begin{array}{l}\text { Suspended } \\
\text { solids } \\
(\mathrm{mg} / \mathrm{L})\end{array}$ & $\begin{array}{c}\text { Nitrogen, } \\
\text { total } \\
\text { Kehldahl } \\
(\mathrm{mg} / \mathrm{L})\end{array}$ & $\begin{array}{l}\text { Nitrogen, } \\
\text { total } \\
(\mathrm{mg} / \mathrm{L})\end{array}$ & $\begin{array}{l}\text { Phos- } \\
\text { phorus, } \\
\text { dissolved } \\
(\mathrm{mg} / \mathrm{L})\end{array}$ & $\begin{array}{c}\text { Phos- } \\
\text { phorus, } \\
\text { total } \\
\text { (mg/L) }\end{array}$ \\
\hline $\begin{array}{l}\text { North Floodway nr. } \\
\text { Alameda } 08329900 \\
\text { (UR9900) }\end{array}$ & $\begin{array}{l}10 / 7 / 2003 \\
11 / 12 / 2003 \\
3 / 4 / 2004 \\
4 / 8 / 2004 \\
7 / 12 / 2004\end{array}$ & $\begin{array}{c}42.4 \\
342 \\
440 \\
245 \\
1,790\end{array}$ & $\begin{array}{r}1,310 \\
408 \\
744 \\
464 \\
1,088\end{array}$ & $\begin{array}{r}105 \\
170 \\
60 \\
80 \\
24\end{array}$ & $\begin{array}{r}1,040 \\
1,548 \\
852 \\
710 \\
1,812\end{array}$ & $\begin{array}{l}3.17 \\
4.6 \\
1.5 \\
1.85 \\
3.86\end{array}$ & $\begin{array}{l}3.72 \\
5.47 \\
1.75 \\
2.19 \\
4.61\end{array}$ & $\begin{array}{r}0.206 \\
.384 \\
.116 \\
.125 \\
.208\end{array}$ & $\begin{array}{r}5.45 \\
1.04 \\
.92 \\
.73 \\
1.92\end{array}$ \\
\hline $\begin{array}{l}\text { South Diversion Channel } \\
\text { nr. Albq. } 08330775 \\
\text { (UR200) }\end{array}$ & $\begin{array}{l}10 / 7 / 2003 \\
11 / 12 / 2003 \\
3 / 4 / 2004 \\
7 / 12 / 2004 \\
7 / 15 / 2004\end{array}$ & $\begin{array}{r}63.3 \\
15.4 \\
5.8 \\
14.9 \\
24.1\end{array}$ & $\begin{array}{l}69.3 \\
19.2 \\
90 \\
17.1 \\
30.4\end{array}$ & $\begin{array}{r}142 \\
202 \\
92 \\
148 \\
----\end{array}$ & $\begin{array}{r}1,140 \\
140 \\
776 \\
632 \\
----\end{array}$ & $\begin{array}{l}3.75 \\
1.3 \\
2.26 \\
3.5 \\
3.95\end{array}$ & $\begin{array}{l}4.41 \\
1.83 \\
2.67 \\
4.5 \\
4.95\end{array}$ & $\begin{array}{l}.153 \\
.15 \\
.064 \\
.043 \\
.265\end{array}$ & $\begin{array}{l}1.4 \\
.306 \\
.82 \\
.726 \\
.965\end{array}$ \\
\hline $\begin{array}{l}\text { San Jose Drain@ } \\
\text { Woodward Rd.@Albq. } \\
08330200 \text { (UR500) }\end{array}$ & $\begin{array}{l}10 / 7 / 2003 \\
11 / 12 / 2003 \\
2 / 23 / 2004 \\
3 / 4 / 2004 \\
6 / 29 / 2004 \\
7 / 12 / 2004\end{array}$ & $\begin{array}{r}3.8 \\
4.9 \\
2.3 \\
6.5 \\
13.7 \\
10.7\end{array}$ & $\begin{array}{r}18.4 \\
6.6 \\
8.3 \\
11.9 \\
20.3 \\
28.2\end{array}$ & $\begin{array}{r}138 \\
200 \\
206 \\
78 \\
308 \\
60\end{array}$ & $\begin{array}{l}456 \\
176 \\
560 \\
464 \\
600 \\
532\end{array}$ & $\begin{array}{c}3.65 \\
3.95 \\
5.03 \\
2.27 \\
11 \\
5.28\end{array}$ & $\begin{array}{c}4.4 \\
4.94 \\
5.75 \\
2.85 \\
12.8 \\
6.48\end{array}$ & $\begin{array}{l}.26 \\
.411 \\
.223 \\
.144 \\
.693 \\
.404\end{array}$ & $\begin{array}{c}1.22 \\
.742 \\
1.19 \\
.654 \\
1.82 \\
1.25\end{array}$ \\
\hline $\begin{array}{l}\text { Mariposa Diversion of } \\
\text { San Antonio Arroyo @ } \\
\text { Albq. 083299375 } \\
\text { (UR300) }\end{array}$ & $\begin{array}{l}10 / 7 / 2003 \\
9 / 29 / 2004\end{array}$ & $\begin{array}{l}12.4 \\
11.9\end{array}$ & $\begin{array}{l}16.3 \\
21.6\end{array}$ & $\begin{array}{r}100 \\
74\end{array}$ & $\begin{array}{l}136 \\
176\end{array}$ & $\begin{array}{l}1.3 \\
1.4\end{array}$ & $\begin{array}{l}1.74 \\
1.85\end{array}$ & $\begin{array}{l}.24 \\
.184\end{array}$ & $\begin{array}{l}.335 \\
.385\end{array}$ \\
\hline $\begin{array}{l}\text { Barelas Pump Station } \\
\text { (UR400) }\end{array}$ & $\begin{array}{l}10 / 7 / 2003 \\
9 / 19 / 2004\end{array}$ & $\begin{array}{l}\text { N/A } \\
\text { N/A }\end{array}$ & $\begin{array}{l}\text { N/A } \\
\text { N/A }\end{array}$ & $\begin{array}{r}190 \\
92\end{array}$ & $\begin{array}{l}652 \\
120\end{array}$ & $\begin{array}{l}4.7 \\
2.7\end{array}$ & $\begin{array}{l}5.66 \\
3.42\end{array}$ & $\begin{array}{l}.289 \\
.212\end{array}$ & $\begin{array}{l}1.51 \\
.507\end{array}$ \\
\hline $\begin{array}{l}\text { North Floodway Outfall } \\
\text { (UR9901) }\end{array}$ & $10 / 7 / 2003$ & $\mathrm{~N} / \mathrm{A}$ & $\mathrm{N} / \mathrm{A}$ & 110 & 348 & 2.60 & 3.17 & .213 & .21 \\
\hline $\begin{array}{l}\text { North Pino Arroyo } \\
\text { Detention Pond } \\
\text { (UR9884) }\end{array}$ & $11 / 14 / 2003$ & N/A & N/A & 76 & 74 & 1.04 & 1.54 & .177 & .224 \\
\hline
\end{tabular}


Table 2. Albuquerque Storm-Water Sampling Program - National Pollution Discharge Elimination System concentrations of 12 priority water-quality constituents plus bacteria for 2004--Continued.

\begin{tabular}{|c|c|c|c|c|c|c|c|c|}
\hline $\begin{array}{l}\text { Sampling site and } \\
\text { USGS number } \\
\text { (cooperator } \\
\text { number) }\end{array}$ & $\begin{array}{l}\text { Biochem. } \\
\text { oxygen } \\
\text { demand } \\
(\mathrm{mg} / \mathrm{L})\end{array}$ & $\begin{array}{l}\text { Chemical } \\
\text { oxygen } \\
\text { demand } \\
(\mathrm{mg} / \mathrm{L})\end{array}$ & $\begin{array}{c}\text { Cadmium, } \\
\text { total } \\
(\mu \mathrm{g} / \mathrm{L})\end{array}$ & $\begin{array}{c}\text { Lead, } \\
\text { total } \\
(\mu \mathrm{g} / \mathrm{L})\end{array}$ & $\begin{array}{l}\text { Copper, } \\
\text { total } \\
(\mu \mathrm{g} / \mathrm{L})\end{array}$ & $\begin{array}{c}\text { Zinc } \\
(\mu \mathrm{g} / \mathrm{L})\end{array}$ & $\begin{array}{l}\text { Coliform, } \\
\text { fecal } \\
(\text { cols } / 100 \text { ml) }\end{array}$ & $\begin{array}{c}\text { E. coli } \\
(\mathrm{mpn} / \mathbf{1 0 0} \mathrm{ml})\end{array}$ \\
\hline $\begin{array}{l}\text { North Floodway nr. } \\
\text { Alameda 08329900 } \\
\text { (UR9900) }\end{array}$ & $\begin{array}{l}19 \\
60 \\
--- \\
16.1 \\
13\end{array}$ & $\begin{array}{r}202 \\
245 \\
220 \\
66 \\
480\end{array}$ & $\begin{array}{r}3.16 \\
.81 \\
.33 \\
.48 \\
1.13\end{array}$ & $\begin{array}{l}60.8 \\
36.1 \\
37.6 \\
25.3 \\
94.5\end{array}$ & $\begin{array}{l}40 \\
38.8 \\
29.8 \\
22.6 \\
56.7\end{array}$ & $\begin{array}{l}333.5 \\
145 \\
250 \\
187 \\
345\end{array}$ & $\begin{array}{r}270,000 \\
4,570 \\
1,160 \\
584 \\
27,124\end{array}$ & $\begin{array}{r}900 \\
19,000 \\
6,010 \\
1,900 \\
18,983\end{array}$ \\
\hline $\begin{array}{l}\text { South Diversion Channel } \\
\text { nr. Albq. } 08330775 \\
\text { (UR200) }\end{array}$ & $\begin{array}{c}14 \\
180 \\
22.4 \\
25 \\
----\end{array}$ & $\begin{array}{l}210 \\
303 \\
250 \\
560 \\
240\end{array}$ & $\begin{array}{r}4.69 \\
.19 \\
.55 \\
.63 \\
.62\end{array}$ & $\begin{array}{l}77.2 \\
13.7 \\
90.4 \\
57.7 \\
62.8\end{array}$ & $\begin{array}{l}57.3 \\
24.1 \\
38.7 \\
25.3 \\
27.9\end{array}$ & $\begin{array}{l}495.5 \\
.01 \\
346 \\
139 \\
164\end{array}$ & $\begin{array}{r}19,000 \\
1,480 \\
273 \\
43,840 \\
9,492\end{array}$ & $\begin{array}{r}900 \\
4,570 \\
45 \\
9,492 \\
9,492\end{array}$ \\
\hline $\begin{array}{l}\text { San Jose Drain@ } \\
\text { Woodward Rd. @ Albq. } \\
08330200 \text { (UR500) }\end{array}$ & $\begin{array}{l}20 \\
60 \\
29.7 \\
14.8 \\
80 \\
23\end{array}$ & $\begin{array}{l}226 \\
256 \\
150 \\
290 \\
460 \\
480\end{array}$ & $\begin{array}{r}3.69 \\
.65 \\
.93 \\
.44 \\
.92 \\
1.07\end{array}$ & $\begin{array}{c}95.2 \\
44 \\
118 \\
54.6 \\
108 \\
96.4\end{array}$ & $\begin{array}{l}43.7 \\
35.1 \\
57 \\
35.3 \\
52 \\
40.5\end{array}$ & $\begin{array}{l}409 \\
103 \\
478 \\
339 \\
331 \\
278\end{array}$ & $\begin{array}{r}19,000 \\
7,600 \\
230 \\
1,160 \\
43,800 \\
27,124\end{array}$ & $\begin{array}{r}27,100 \\
7,600 \\
220 \\
522 \\
27,100 \\
43,840\end{array}$ \\
\hline $\begin{array}{l}\text { Mariposa Diversion of } \\
\text { San Antonio Arroyo @ } \\
\text { Albq. 083299375 } \\
\text { (UR300) }\end{array}$ & 12 & $\begin{array}{r}92 \\
100\end{array}$ & $\begin{array}{l}<2 \\
.2\end{array}$ & $\begin{array}{l}4.31 \\
8.54\end{array}$ & $\begin{array}{l}7.74 \\
13.2\end{array}$ & $\begin{array}{l}40.7 \\
40.9\end{array}$ & $\begin{array}{r}7,600 \\
500\end{array}$ & $\begin{array}{r}7,600 \\
500\end{array}$ \\
\hline $\begin{array}{l}\text { Barelas Pump Station } \\
\text { (UR400) }\end{array}$ & $\begin{array}{l}34 \\
15.6\end{array}$ & $\begin{array}{l}303 \\
123\end{array}$ & $\begin{array}{r}4.41 \\
.31\end{array}$ & $\begin{array}{r}108.4 \\
20.8\end{array}$ & $\begin{array}{l}74 \\
19.5\end{array}$ & $\begin{array}{l}645 \\
144\end{array}$ & $\begin{array}{r}270,000 \\
1,600\end{array}$ & $\begin{array}{r}900 \\
1,600\end{array}$ \\
\hline $\begin{array}{l}\text { North Floodway Outfall } \\
\text { (UR9901) }\end{array}$ & 17 & 161 & 2.57 & 28.1 & 22.5 & 137 & 19,000 & 27,100 \\
\hline $\begin{array}{l}\text { North Pino Arroyo } \\
\text { Detention Pond } \\
\text { (UR9884) }\end{array}$ & 14 & 130 & .08 & 3.08 & 9.34 & .01 & 2,860 & 300 \\
\hline
\end{tabular}


Table 2. Albuquerque Storm-Water Sampling Program - National Pollution Discharge Elimination System concentrations of 12 priority water-quality constituents plus bacteria for 2004--Continued.

\begin{tabular}{|c|c|c|c|c|c|}
\hline $\begin{array}{c}\text { Sampling site } \\
\text { and USGS } \\
\text { number } \\
\text { (cooperator number) }\end{array}$ & $\begin{array}{c}\text { Date } \\
\text { sampled }\end{array}$ & Time & $\begin{array}{c}\text { Grab } \\
\text { sample } \\
\text { discharge } \\
\left(\mathrm{ft}^{3} / \mathrm{s}\right)\end{array}$ & $\begin{array}{c}\text { Coliform, } \\
\text { fecal } \\
(\text { cols } / 100 \mathrm{ml})\end{array}$ & $\begin{array}{c}\text { E. coli } \\
(\mathrm{mpn} / 100 \mathrm{ml})\end{array}$ \\
\hline $\begin{array}{l}\text { Pino Arroyo at Jefferson St. } 08329882 \\
\text { (UR2020) }\end{array}$ & $\begin{array}{l}10 / 7 / 2003 \\
11 / 12 / 2003\end{array}$ & $\begin{array}{l}16: 10 \\
19: 40\end{array}$ & $\begin{array}{l}90.1 \\
34.7\end{array}$ & $\begin{array}{l}12,400 \\
44,000\end{array}$ & $\begin{array}{r}27,100 \\
950\end{array}$ \\
\hline $\begin{array}{l}\text { Embudo Arroyo at Albq. } 08329720 \\
\text { (UR650) }\end{array}$ & $\begin{array}{l}10 / 7 / 2003 \\
3 / 4 / 2004 \\
6 / 28 / 2004 \\
7 / 27 / 2004\end{array}$ & $\begin{array}{r}19: 55 \\
7: 05 \\
16: 25 \\
20: 35\end{array}$ & $\begin{array}{l}.41 \\
.85 \\
3.9 \\
1.5\end{array}$ & $\begin{array}{r}19,000 \\
6,010 \\
950 \\
43,840\end{array}$ & $\begin{array}{r}900 \\
73 \\
359 \\
43,840\end{array}$ \\
\hline $\begin{array}{l}\text { North Floodway Channel @ Albq. } 08329835 \\
\text { (UR329835) }\end{array}$ & $10 / 7 / 2003$ & $15: 05$ & 1,120 & 270,000 & 900 \\
\hline $\begin{array}{l}\text { Hahn Arroyo 08329840 } \\
\text { (UR08329840) }\end{array}$ & $\begin{array}{l}10 / 7 / 2003 \\
11 / 12 / 2003 \\
7 / 12 / 2004 \\
7 / 23 / 2004\end{array}$ & $\begin{array}{l}14: 40 \\
16: 45 \\
17: 55 \\
16: 42\end{array}$ & $\begin{array}{c}58.3 \\
71.5 \\
337 \\
52.1\end{array}$ & $\begin{array}{r}270,000 \\
950 \\
7,599 \\
2,862\end{array}$ & $\begin{array}{r}900 \\
4,570 \\
3,875 \\
4,571\end{array}$ \\
\hline $\begin{array}{l}\text { Tijeras Arroyo nr. Albq. } \\
08330600 \\
\text { (UR330600) }\end{array}$ & $\begin{array}{l}10 / 7 / 2003 \\
3 / 4 / 2004 \\
7 / 22 / 2004\end{array}$ & $\begin{array}{l}15: 50 \\
10: 35 \\
19: 25\end{array}$ & $\begin{array}{r}101 \\
91.8 \\
2.5\end{array}$ & $\begin{array}{r}4,570 \\
23 \\
5,842\end{array}$ & $\begin{array}{r}4,570 \\
273 \\
2,862\end{array}$ \\
\hline $\begin{array}{l}\text { Bear Arroyo at Jefferson } \\
\text { Street (08329870) } \\
\text { (UR329870) }\end{array}$ & $\begin{array}{l}11 / 12 / 2003 \\
2 / 23 / 2004 \\
4 / 8 / 2004 \\
6 / 29 / 2004 \\
7 / 12 / 2004 \\
7 / 22 / 2004\end{array}$ & $\begin{array}{r}21: 52 \\
18: 30 \\
10: 45 \\
6: 20 \\
18: 15 \\
20: 15\end{array}$ & $\begin{array}{r}10.5 \\
1.7 \\
3.6 \\
1.5 \\
2.7 \\
16.2\end{array}$ & $\begin{array}{r}7,600 \\
230 \\
3,840 \\
43,500 \\
4,571 \\
359\end{array}$ & $\begin{array}{r}950 \\
500 \\
2,710 \\
4,570 \\
4,571 \\
359\end{array}$ \\
\hline
\end{tabular}

${ }^{1}$ Grab sample is collected within the first 20 minutes of stormflow.

${ }^{2}$ See composite sample definition on page 5 . 


\section{RAINFALL AND RUNOFF DATA COLLECTION}

During water year 2004, 18 streamflow-gaging stations, 39 rain gages, and 5 crest-stage gages were operational in the Albuquerque urban-data collection program. Five gaging stations measure runoff from undeveloped drainage basins, and the remaining 13 stations monitor runoff from urbanized watersheds. The streamflow gages at Academy Acres Drain, North Fork Hahn Arroyo, and South Fork Hahn Arroyo, all in urbanized watersheds, were discontinued in July 2003. Eleven gaging stations also are water-quality sampling sites. All data are recorded at 5minute intervals and transferred from the field recorders to the USGS electronic database approximately every month. The period of record for data (unit values) digitally archived in electronic format and stored in the USGS database is listed in table 3. Data collected prior to the dates listed in table 3 are archived in paper-tape form at the USGS New Mexico Water Science Center in Albuquerque and can be converted to electronic format if needed. A similar periodof-record tabulation is available for rain gages and is listed in table 4. In the station analyses for rain-gage sites that are presented later in this report, the period of record refers only to data readily available in electronic format.

Six gaging stations were operated only from approximately October 1 to November 30, 2003, and March 1 to September 30, 2004, when the probability of rainfall is higher. These six seasonal sites are: EmbudoArroyo at Monte Largo, Ladera Arroyo, Arroyo 19A, Pino Arroyo at Jefferson St., La Cueva Arroyo Tributary, and North Camino Arroyo at Sunset Hills. Rainfall data are collected annually using tipping-bucket rain gages. A typical rainfall collection site and tipping-bucket rain gage are shown in figure 2 .

Four of the five crest-stage gages only document the highest water level that had occurred between site visits. The Calabacillas Arroyo below Coors Blvd. crest-stage gage pipe shelter actually houses a small pressure transducer that also records water levels every 5 minutes. Only the peak flows for the 2004 water year are displayed in this report for each crest-stage gage.

\section{ANNUAL DAILY MEAN FLOW HYDROGRAPH OF THE NORTH FLOODWAY CHANNEL AND THE RIO GRANDE AT ALBUQUERQUE GAGING STATIONS}

The North Floodway Channel (not shown on map) drains the northeast quadrant of Albuquerque and is the largest of the concrete-lined drainage channels in the metropolitan area. Its confluence with the Rio Grande is located immediately north of the Albuquerque city limits near the small community of Alameda. North Floodway Channel discharges into the Rio Grande are measured at the North Floodway Channel near Alameda gaging station (08329900). A hydrographic comparison showing the effects of North Floodway flows on Rio Grande mean daily discharges measured at the Rio Grande at Albuquerque gaging station (08330000) is shown in figure 3. The Rio Grande gaging station is approximately 10 miles downstream from the confluence with the North Floodway Channel. The snowmelt runoff period from April through June, during which peak flows typically occur in any given year, was below normal in water year 2004. Average annual flow at the Rio Grande at Albuquerque gaging station was 683 cubic feet per second and at the North Floodway gaging station was 11.4 cubic feet per second, or slightly more than 1 percent of annual riverflow in water year 2004. The hydrograph shows that large stormflows from the North Floodway are usually reflected in the Rio Grande and that 
the effects of North Floodway flows are more pronounced when total river discharge is low. Most North Floodway peaks occur during the summer thunderstorm season (July-October) when flow in the Rio Grande is typically at its lowest level. Therefore, the larger Albuquerque urban stormflows usually are a significant percentage of the mean daily discharge of the Rio Grande. The water year 2004 instantaneous peak discharge at the North Floodway gaging station was 5,700 cubic feet per second on July 23, 2004. The daily mean discharge of the North Floodway on that day was 371 cubic feet per second or approximately 59 percent of flow of the Rio Grande at Albuquerque gaging station. The water year 2004 maximum daily mean discharge for the North Floodway during the snowmelt period (April-May) was 309 cubic feet per second, which occurred on April 3. On that day, the North Floodway flow was only approximately 13 percent of the 2,310 cubic feet per second recorded at the Rio Grande at Albuquerque gage.

Table 3. Period of record of digitally archived unit values for urban streamflow-gaging stations.

[*, Unit values recorded only during water-quality sampling events prior to 1999]

\begin{tabular}{rlcc}
\hline $\begin{array}{r}\text { Site ID } \\
\text { (fig. 1) }\end{array}$ & \multicolumn{1}{c}{ Station name } & $\begin{array}{c}\text { Station } \\
\text { number }\end{array}$ & $\begin{array}{c}\text { Period of } \\
\text { record }\end{array}$ \\
\hline 30 & Campus Wash @ Albq. & 08329700 & $03 / 90-09 / 04$ \\
5 & Embudo Arroyo @ Albq. & 08329720 & $10 / 98-09 / 04$ \\
28 & North Floodway Channel @ Albq. & 08329835 & $03 / 90-09 / 04$ \\
19 & South Fork Hahn Arroyo @ Albq. & 08329838 & $06 / 92-07 / 03$ \\
not shown & North Fork Hahn Arroyo @ Albq. & 08329839 & $06 / 92-07 / 03$ \\
& & & \\
22 & Hahn Arroyo @ Albq. & 08329840 & $06 / 92-09 / 04$ \\
not shown & Grant Line Arroyo @ Villa del Oso @ Albq. & 08329860 & $03 / 84-07 / 98$ \\
2 & Bear Canyon Arroyo near Albq. & 08329868 & $10 / 99-09 / 04$ \\
24 & Bear Arroyo at Jefferson St. & 08329870 & $06 / 03-09 / 04$ \\
20 & Academy Acres Drain @ Albq. & 08329880 & $10 / 84-07 / 03$ \\
23 & Pino Arroyo @ Jefferson St. @ Albq. & 08329882 & $05 / 00-09 / 04$ \\
& & & \\
7 & La Cueva Arroyo Tributary @, Albq. & 08329888 & $05 / 99-09 / 04$ \\
26 & La Cueva Arroyo Trib. near Albq. @@ Tramway Rd.) & 08329890 & $09 / 90-07 / 95$ \\
13 & N. Floodway Channel near Alameda & 08329900 & $10 / 88-09 / 04$ \\
18 & North Camino Arroyo @, Sunset Hills in Albq. & 08329911 & $08 / 97-09 / 04$ \\
& North Camino Arroyo Trib. @ Albq. & 08329914 & $10 / 93-09 / 97$ \\
44 & Arroyo 19A @ Albq. & & \\
37 & Taylor Ranch Drain @ Albq. & 08329935 & $10 / 91-09 / 04$ \\
39 & Mariposa Diversion of San Antonio Arroyo @ Albq. & 083299375 & $* 10 / 94-09 / 04$ \\
46 & Ladera Arroyo @ Albq. & 08329938 & $10 / 91-09 / 04$ \\
33 & San Jose Drain @ Woodward Road @ Albq. & 08330200 & $* 09 / 99-09 / 04$ \\
& & & \\
32 & Tramway Floodway Channel @ Albq & 08330540 & $10 / 94-09 / 04$ \\
35 & Sijeras Arroyo near Albq. & 08330600 & $03 / 96-09 / 04$ \\
42 & Amole del Norte Channel @ Albq. & 08330775 & $10 / 94-09 / 04$ \\
& & 08331118 & $04 / 00-09 / 04$ \\
\hline
\end{tabular}

\footnotetext{
${ }^{1}$ Data collected prior to dates listed are archived in paper-tape format.
} 
Table 4. Period of record of digitally archived unit values for urban rain-gage sites.

\begin{tabular}{|c|c|c|c|}
\hline $\begin{array}{l}\text { Site ID } \\
\text { (fig. 1) }\end{array}$ & Station name & $\begin{array}{c}\text { Station } \\
\text { number }\end{array}$ & $\begin{array}{l}\text { Period of } \\
\text { record }^{1}\end{array}$ \\
\hline 1 & Bear Canyon in Albuquerque & 350859106274330 & $10 / 84-09 / 04$ \\
\hline 3 & Elena Gallegos Picnic Area@ Albq. & 350954106282330 & $10 / 94-09 / 04$ \\
\hline 4 & Embudo Canyon@, Albuquerque & 350554106283230 & $06 / 99-09 / 04$ \\
\hline 7 & La Cueva Arroyo Trib.nr. Albuquerque (@,Tramway Rd.) & 08329890 & $07 / 77-09 / 04$ \\
\hline 8 & Tramway Floodway Channel @ Albq. & 08330540 & $04 / 01-09 / 04$ \\
\hline 9 & Fire Station \#16 in Albuquerque & 350756106305430 & $10 / 84-09 / 04$ \\
\hline 10 & Walker Pump Station & 351023106313930 & $04 / 02-09 / 04$ \\
\hline 11 & Borland Rain Gage in Albuquerque & 350713106314230 & $10 / 84-09 / 04$ \\
\hline 12 & Tanoan Rain Gage@Albuquerque & 350924106315630 & $04 / 91-09 / 04$ \\
\hline 14 & Kirtland Air Force Base @ Eubank Gate, Albq. & 350310106320930 & $06 / 01-09 / 04$ \\
\hline 15 & Leonard Rain Gage in Albuquerque & 350722106325030 & $04 / 84-09 / 04$ \\
\hline 16 & Thomas Pump Station@ Albuquerque & 350755106325830 & $10 / 94-09 / 04$ \\
\hline 17 & Love Pump Station@ Albq. & 350540106333230 & $09 / 02-09 / 04$ \\
\hline 18 & North Camino Arroyo Trib. @ Albuquerque & 08329914 & $06 / 79-09 / 04$ \\
\hline 19 & South Fork Hahn Arroyo@ Albuquerque & 08329838 & $10 / 78-09 / 04$ \\
\hline not shown & North Fork Hahn Arroyo@ Albuquerque & 08329839 & $06 / 79-07 / 03$ \\
\hline not shown & Grant Line Arroyo@ Villa del Oso@ Albq. & 08329860 & $06 / 76-07 / 03$ \\
\hline 20 & Academy Acres Drain@ Albuquerque & 08329880 & $07 / 76-09 / 04$ \\
\hline 21 & USGS Office at Albq. & 350748106345830 & $08 / 00-09 / 04$ \\
\hline 22 & Hahn Arroyo@Albuquerque & 08329840 & $10 / 78-09 / 04$ \\
\hline 26 & North Floodway Channel near Alameda & 08329900 & $12 / 01-09 / 04$ \\
\hline 25 & Tijeras Arroyo@ Montessa Park near Albq. & 08330580 & $10 / 95-09 / 04$ \\
\hline 27 & Orlando Romero Rain Gage in Albq. & 350417106363330 & $03 / 01-09 / 04$ \\
\hline 28 & North Floodway Channel @ Albuquerque & 08329835 & $07 / 99-09 / 04$ \\
\hline 29 & AMAFCA Headquarters near Albuquerque & 350627106364630 & $09 / 97-09 / 04$ \\
\hline 30 & Campus Wash@Albuquerque & 08329700 & $10 / 84-09 / 04$ \\
\hline 31 & Bernalillo County Building near Albq. & 350340106385230 & 09/97 - 09/04 \\
\hline 33 & San Jose Drain@ WoodwardRoad@ Albq. & 08330200 & $12 / 94-09 / 04$ \\
\hline 34 & Albuquerque City Hall@ Albuquerque & 350448106390230 & $10 / 94-09 / 04$ \\
\hline 36 & Wastewater Treatment Plant @ Albq. & 350119106394630 & $08 / 00-09 / 04$ \\
\hline 37 & Taylor Ranch Drain@ Albuquerque & 08329936 & $08 / 78-09 / 04$ \\
\hline 38 & Swinburn Dam Rain Gage @ Paradise Hills & 351216106421330 & $08 / 00-09 / 04$ \\
\hline 40 & PetroglyphsPark@Albuquerque & 350939106430930 & $02 / 95-09 / 04$ \\
\hline 41 & Todd Kelly Rain Gage @ Rio Rancho & 351516106431430 & $10 / 02-09 / 04$ \\
\hline 43 & Leavitt Pump Station@ Albuquerque & 350310106434930 & $08 / 00-09 / 04$ \\
\hline 44 & Arroyo19A@ Albuquerque & 08329935 & $06 / 77-09 / 04$ \\
\hline 45 & Fire Station \#14 in Albuquerque & 350357106434930 & $10 / 84-09 / 04$ \\
\hline 46 & Ladera Arroyo@ Albuquerque & 08329938 & $05 / 87-09 / 04$ \\
\hline 47 & Emergency Dispatch Bldg.@ Albq. & 350348106453230 & $10 / 00-09 / 04$ \\
\hline 48 & La Boca Negra near Albuquerque & 350912106455630 & $10 / 90-09 / 04$ \\
\hline 49 & Crown Towers@ Nine Mile Hill@ Albq. & 350400106465630 & $08 / 00-09 / 04$ \\
\hline 50 & Rio Rancho Well \#13 & 351631106481230 & $07 / 04-09 / 04$ \\
\hline
\end{tabular}

${ }^{1}$ Data collected prior to dates listed are archived in paper-tape format. 
A

$\vec{\omega}$

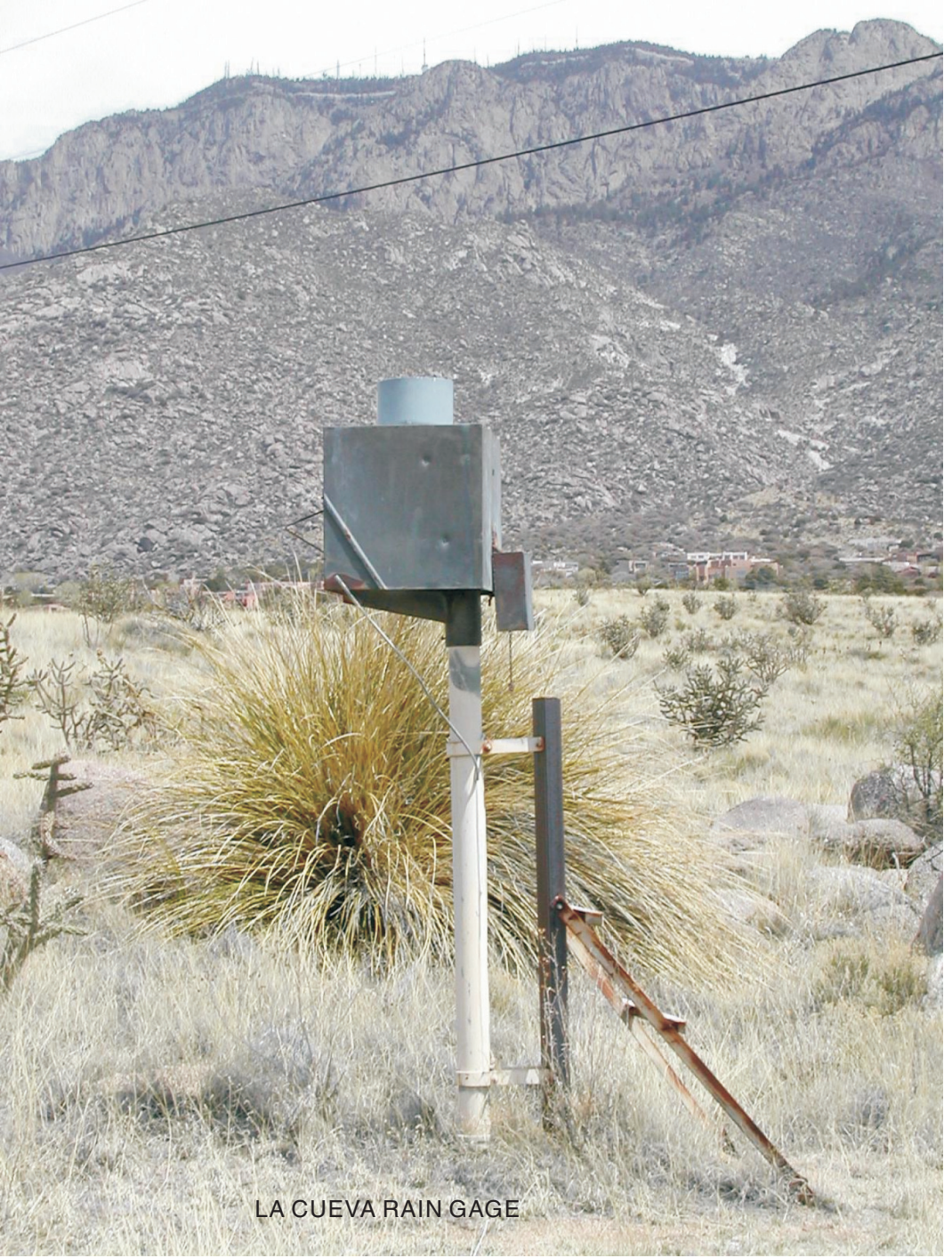

\section{B}
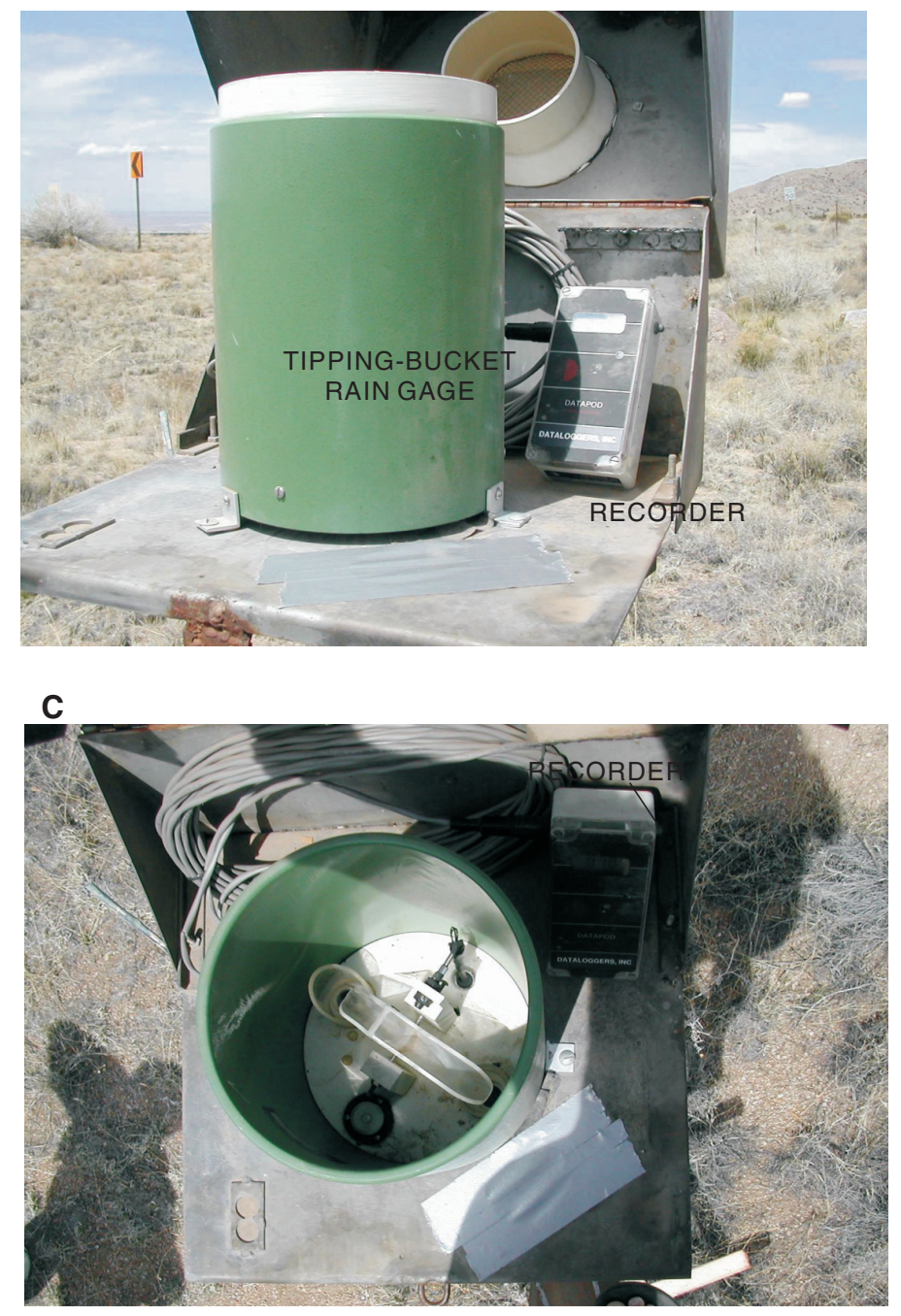

CLOSE UP OF TIPPING MECHANISM INSIDE RAIN GAGE

Figure 2. (A) La Cueva rain gage, (B) recorder next to rain gage, and (C) view inside of rain gage. 


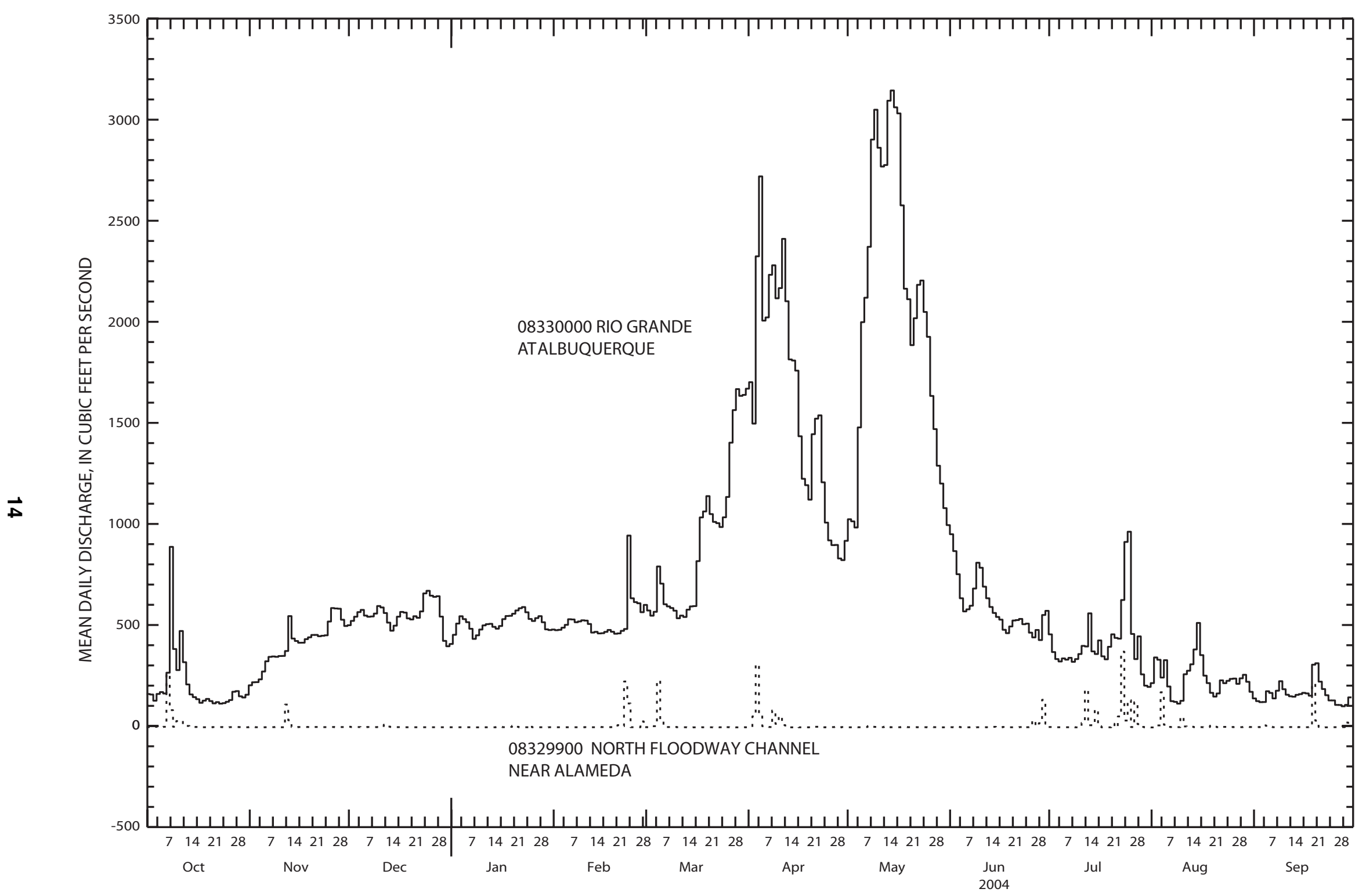

Figure 3. Discharge at the North Floodway Channel near Alameda in comparision to discahrge at the Rio Grande at Albuquerque streamflow-gaging stations. 


\section{REFERENCES CITED}

Fischer, E.E., Rote, J.J., and Borland, J.P., 1984, Rainfall-runoff data in the Albuquerque, New Mexico, metropolitan area, 1976-83: U.S. Geological Survey Open-File Report 84-448, $306 \mathrm{p}$.

Kelly, Todd, and Romero, Orlando, 2003, Rainfall, runoff, and water-quality data for the urban storm-water program in the Albuquerque, New Mexico, metropolitan area, water year 2001: U.S. Geological Survey Open-File Report 03-169, 153 p.

Kelly, Todd, and Romero, Orlando, 2004, Rainfall, runoff, and water-quality data for the urban storm-water program in the Albuquerque, New Mexico, metropolitan area, water year 2002: U.S. Geological Survey Open-File Report 2004-1347, 119 p.

Kelly, Todd, and Romero, Orlando, 2005, Rainfall, runoff, and water-quality data for the urban storm-water program in the Albuquerque, New Mexico, metropolitan area, water year 2003 U.S. Geological Survey Open-File Report 2005-1266, 120 p.

Metzker, K.D., Gold, R.L., and Thomas, R.P., 1993, Rainfall and runoff data for the Albuquerque, New Mexico, metropolitan area, 1984-88: U.S. Geological Survey Open-File Report 92-653, 388 p.

National Oceanic and Atmospheric Administration, www.cdc.noaa.gov/usclimate, accessed April 8, 2002. 
RUNOFF DATA SUMMARY, WATER YEAR 2004

\section{(arranged by station number)}




\section{SURFACE-WATER RUNOFF DATA FOR WATER YEAR 2004}

This section presents the daily mean discharge tables for the 18 streamflow-gaging stations operating in water year 2004. Detailed location descriptions, drainage areas, periods of record, and statistical summaries are included in each table. No statistical analysis is computed for the gaging stations not operated continuously during water years 2003 and 2004. A stationspecific analysis supplements each daily values table and includes a description of monitoring equipment, problems associated with data collection during the water year, and other information used to compute streamflow discharge. The annual maximum peak stage and annual maximum peak discharge for water year 2004 and for the period of record for all gaging stations are listed in table 5. 
Table 5. Maximum flood peak stage and discharge for water year 2004 and for the period of record.

\begin{tabular}{|c|c|c|c|c|c|c|c|c|c|}
\hline \multirow[b]{2}{*}{$\begin{array}{l}\text { Station } \\
\text { number }\end{array}$} & \multirow[b]{2}{*}{ Station name } & \multirow[b]{2}{*}{$\begin{array}{c}\text { Date station } \\
\text { was established }\end{array}$} & \multicolumn{3}{|c|}{ Water year 2004} & \multicolumn{3}{|c|}{ Period of record } & \multirow[b]{2}{*}{ Remarks } \\
\hline & & & $\begin{array}{c}\text { Date of } \\
\text { peak }\end{array}$ & $\begin{array}{c}\text { Maximum } \\
\text { stage } \\
\text { (ft) }\end{array}$ & $\begin{array}{c}\text { Maximum } \\
\text { peak } \\
\left(\mathbf{f t}^{3} / \mathbf{s}\right) \\
\end{array}$ & $\begin{array}{c}\text { Date of } \\
\text { peak }\end{array}$ & $\begin{array}{c}\text { Maximum } \\
\text { stage } \\
\text { (ft) } \\
\end{array}$ & $\begin{array}{l}\text { Maximum } \\
\text { peak }\left(\mathrm{ft}^{3} / \mathbf{s}\right)\end{array}$ & \\
\hline 08329700 & Campus Wash@Albq. & Apr-82 & $7 / 23 / 2004$ & 3.61 & 866 & $7 / 14 / 1990$ & 4.50 & 1,230 & \\
\hline 08329720 & Embudo Arroyo@Albq. & Oct-98 & $8 / 4 / 2004$ & 3.31 & 16 & $8 / 4 / 2004$ & 3.31 & 16 & \\
\hline 08329835 & N. Floodway Channel @ Albq. & May-82 & $7 / 23 / 2004$ & 9.30 & 4,880 & 7/9/1988 & 12.10 & 8,180 & \\
\hline 08329839 & North Fork Hahn Arroyo & June-92 & ---- & ---- & ---- & $8 / 1 / 1993$ & 1.90 & 219 & Discontinued 7/03 \\
\hline 08329838 & South Fork Hahn Arroyo & June-92 & ---- & ---- & ---- & $6 / 16 / 1999$ & 4.72 & 1,300 & Discontinued 7/03 \\
\hline 08329840 & Hahn Arroyo@Albq. & June-78 & $7 / 12 / 2004$ & 2.33 & 676 & $6 / 16 / 1999$ & 5.98 & 6,230 & \\
\hline 08329868 & Bear Canyon Arroyo nr. Albq. & Oct-99 & ---- & ---- & ---- & ---- & 0.00 & 0 & No flows in 2004 \\
\hline 08329870 & Bear Arroyo at Jefferson Street & June-05 & $7 / 12 / 2004$ & 4.66 & 567 & $7 / 12 / 2004$ & 4.66 & 567 & Discontinued 7/03 \\
\hline 08329882 & Pino Arroyo at Jefferson St. & May-00 & $7 / 12 / 2004$ & 3.55 & 728 & $7 / 12 / 2004$ & 3.55 & 728 & \\
\hline 08329888 & La Cueva Arroyo Trib. @ Albq. & May-99 & $8 / 14 / 2004$ & 1.45 & 6.1 & $8 / 14 / 2001$ & 1.56 & 12 & \\
\hline 08329900 & N. Floodway Channel nr. Alameda & July-68 & $7 / 23 / 2004$ & 7.00 & 5,700 & $8 / 14 / 1980$ & 10.40 & 12,300 & \\
\hline 08329911 & N. Camino Arroyo@Sunset Hills & Aug-97 & $6 / 29 / 2004$ & 1.20 & 10 & $7 / 23 / 2001$ & 1.38 & 39 & \\
\hline 08329935 & Arroyo 19A@Albq. & June-77 & $9 / 29 / 2004$ & 1.08 & 0.11 & $8 / 2 / 1999$ & 2.93 & 234 & No flows in 2003 \\
\hline 083299375 & 5 Mariposa Div. of San Antonio Arr. & June-92 & $4 / 3 / 2004$ & 2.67 & 51 & $8 / 4 / 1999$ & 4.80 & 251 & \\
\hline 08329938 & Ladera Arroyo@Albq. & May-81 & $7 / 25 / 2004$ & 2.43 & 4.8 & 8/2/1999 & 4.12 & 195 & No flows in 2003 \\
\hline 08330200 & San Jose Drain at Woodward Rd. & Oct-93 & $7 / 23 / 2004$ & 6.26 & 96 & 8/14/1994 & 6.57 & 99 & \\
\hline 08330540 & Tramway Floodway Channel & July-87 & $8 / 4 / 2004$ & 2.58 & 233 & $7 / 9 / 1988$ & 8.62 & 3,250 & \\
\hline 08330600 & Tijeras Arroyo near Albq. & Oct-51 & $8 / 4 / 2004$ & 6.49 & 929 & $7 / 9 / 1988$ & 9.60 & 2,930 & \\
\hline 08330775 & South Diversion Channel & June-88 & $7 / 23 / 2004$ & 6.70 & 1,300 & $7 / 14 / 1990$ & 6.30 & 1,960 & \\
\hline 08331118 & Amole del Norte Channel @ Albq. & Apr-00 & $7 / 22 / 2004$ & 4.29 & 259 & $7 / 20 / 2003$ & 4.81 & 366 & \\
\hline \multicolumn{10}{|c|}{ Urban Crest-Stage Gages } \\
\hline 8329921 & Calabacillas at Swinburne Dam & Oct-91 & $4 / 3 / 2004$ & approx.0.94 & approx.40 & $6 / 14 / 2002$ & 3.89 & 319 & \\
\hline 8329926 & Calabacillas Arroyo below Coors Blvd. & Jul-05 & $8 / 20 / 2004$ & 1.09 & 363 & $8 / 20 / 2004$ & 1.09 & 363 & \\
\hline 83299236 & Black Arroyo below Golf Course Rd. & Jul-92 & $4 / 3 / 2004$ & 1.66 & 324 & $11 / 13 / 1993$ & 5.36 & 2310 & \\
\hline 83299238 & Seven-Bar Arroyo abv Black Arroyo & Jul-92 & $4 / 3 / 2004$ & .89 & 91 & $11 / 13 / 1993$ & 3.26 & 838 & Peak possibly $5 / 25 / 94$ \\
\hline 8329937 & Boca Negra below Petroglyphs Park & Jul-93 & $4 / 3 / 2004$ & $<.36$ & $<8.5$ & $8 / 2 / 1999$ & .78 & 74 & Discontinued 12/8/04 \\
\hline
\end{tabular}




\section{CAMPUS WASH AT ALBUQUERQUE, NEW MEXICO}

\section{STATION ANALYSIS}

\section{WATER YEAR 2004}

Equipment.--An electronic datalogger, recording stage and rainfall on 5-minute intervals, and a pressure transducer are housed in a metal 5-foot by 5-foot walk-in shelter on the right bank of the concretelined channel. The reference gage is an outside staff gage painted on both sidewalls of the channel. High-water measurements can be made from a bridge located 600 feet upstream, but flow velocities are extrememly fast, so discharges computed from the theoretical rating is considered more accurate than measurements. A tipping-bucket rain gage is also located at this site. The datalogger was installed on July 22, 1996, and the pressure transducer on September 12, 1996. A crest-stage gage (CSG) was installed on the left bank, directly across from the gage house, on October 8, 1998. The elevation of the lower CSG cap is $1.75 \mathrm{ft}$. The pipe is mounted on the side-slope of the channel at an angle of 26.5 degrees from horizontal.

Gage-Height Record.-- The recorder, which is referenced to the outside staff gage, gave a complete and satisfactory record for water year 2004, except for the following time periods. Ice formed over the orifice tubing and affected gage height readings on November 27-29, December 10-11, 13, 16-20, 23-25, 27, and 30-31, 2003, and January 1, 6-10, 22-24, 26-30, and February 3-7, 2004. These estimated daily mean discharges were based on precipitation received at this site and base flows before and after each affected day. No comparison gage is located upstream from this gage and the downstream gage at the North Floodway Channel at Albuquerque (08329835) does not correlate well because most of its flow originates from an ungaged tributary. This gage is operational the entire year.

Rating.--The control for this station is the concrete-lined channel. The bottom width of the channel is 10 feet. The slope of the sides is 26.5 degrees from horizontal. The depth of the channel at this point is about 20 feet. The Point of Zero Flow (PZF) is 0.00 foot (1.00-foot recorded gage height because of the +1.00 foot datum added to true depths).

Rating No. 1 was developed in water year 1982. It was based on a step-backwater analysis of the concrete-lined channel using the software package WSPRO (Water Surface Profile Computations). Rating 1.0 did not compute any flow below a gage height of 0.15 foot, which corresponded to 3.29 cubic feet per second. This "nuisance flow" was not evaluated prior to October 1, 1996.

Beginning in water year 1997, the low end of rating 1.0 was extended and values of discharge were calculated for all gage heights above 0.00 foot. The resulting rating 2.0 also differs slightly from rating 1.0 in that a straight line, best-fit rating line was drawn as close as possible to the theoretical computed values. In rating 1.0, the theoretical values were actually used as input points, which do not plot as a straight line on a log-log scale. For a concrete-lined, trapezoidalshaped channel such as this, the stage versus discharge relationship should plot as a straight line.

Discharge.--Discharge was computed from rating curve 2.0 directly. The channel in this reach creates extreme velocities which keep the channel bottom completely clean. For this reason, no shifting should occur in this uniformly-shaped channel. The rating curve discharges are considered to be more reliable than any individual measurement.

During water year 2004, 21 visits were made to the gaging station. The peak gage height for the water year occurred on July 23 and was 3.61 feet (4.61 on recorder), correlating to a maximum discharge of 866 cubic feet per second. 
Remarks.--Records are good, except those that were estimated due to ice or recorder malfunctions, which are rated poor. Any estimated mean daily discharges are based on precipitation records from this site and base flows typical for the time of year. In recent years, low flow drainage has been increasing and some water is nearly always present in the channel that is not rainfall related ("nuisance flows"). Prior to water year 1997, all days with discharges determined to be only nuisance flow were labeled days of zero flow (gage heights less than 0.15 feet and less than 3.3 cubic feet per second on rating 1.0). Since October 1, 1996, all low-end flow has been calculated using the new rating 2.0 directly. 
RIO GRANDE BASIN

08329700 CAMPUS WASH AT ALBUQUERQUE, NM

LOCATION.--Lat $35^{\circ} 05^{\prime} 38^{\prime \prime}$, long $106^{\circ} 37^{\prime 2} 25^{\prime \prime}$, in SE $1 / 4$ sec.16, T.10 N., R.3 E., Bernalillo County, Hydrologic Unit 13020203 , on right bank 100 ft west of southwest corner of University of New Mexico North Golf Course, $200 \mathrm{ft}$ downstream from Barelas Stormwater Pumping Station outfall, $600 \mathrm{ft}$ downstream from Tucker Road bridge, and 1,500 ft northeast of intersection of Lomas and University Boulevards, in Albuquerque.

DRAINAGE AREA.--3.80 $\mathrm{mi}^{2}$.

PERIOD OF RECORD.--April 1982 to September 1996 (seasonal records). October 1996 to current year.

GAGE.--Water-stage and rainfall recorder and concrete-lined channel. Elevation of gage is 5,143 ft above National Geodetic Vertical Datum of 1929 , from topographic map.

REMARKS.--Records good except for those estimated, which are poor. Recording rain gage at station. Prior to water year 1997, some minor streamflow may exist on days when daily mean discharges have been recorded as zero due to the sensitivity limits of the streamflow monitoring equipment. See tabulation below for monthly precipitation, in inches.

DISCHARGE, CUBIC FEET PER SECOND

WATER YEAR OCTOBER 2003 TO SEPTEMBER 2004 DAILY MEAN VALUES

\begin{tabular}{|c|c|c|c|c|c|c|c|c|c|c|c|c|}
\hline DAY & OCT & NOV & DEC & JAN & FEB & MAR & APR & MAY & JUN & JUL & AUG & SEP \\
\hline $\begin{array}{l}1 \\
2 \\
3 \\
4 \\
5\end{array}$ & $\begin{array}{l}0.45 \\
0.45 \\
0.85 \\
0.60 \\
0.34\end{array}$ & $\begin{array}{l}0.49 \\
0.05 \\
0.14 \\
0.22 \\
0.22\end{array}$ & $\begin{array}{l}0.22 \\
0.25 \\
0.26 \\
0.19 \\
0.25\end{array}$ & $\begin{array}{r}\mathrm{e} 0.10 \\
0.09 \\
0.17 \\
0.00 \\
0.09\end{array}$ & $\begin{array}{r}0.37 \\
0.13 \\
\mathrm{e} 0.10 \\
\mathrm{e} 0.10 \\
\mathrm{e} 0.10\end{array}$ & $\begin{array}{c}0.33 \\
0.80 \\
0.44 \\
13 \\
1.2\end{array}$ & $\begin{array}{l}0.23 \\
4.1 \\
31 \\
1.3 \\
0.24\end{array}$ & $\begin{array}{l}0.15 \\
0.00 \\
0.24 \\
0.22 \\
0.27\end{array}$ & $\begin{array}{l}0.28 \\
0.23 \\
0.27 \\
0.41 \\
0.34\end{array}$ & $\begin{array}{l}0.30 \\
0.28 \\
0.15 \\
0.26 \\
0.31\end{array}$ & $\begin{array}{l}0.37 \\
0.74 \\
0.40 \\
0.84 \\
0.37\end{array}$ & $\begin{array}{l}0.27 \\
0.21 \\
0.24 \\
1.1 \\
0.23\end{array}$ \\
\hline $\begin{array}{r}6 \\
7 \\
8 \\
9 \\
10\end{array}$ & $\begin{array}{l}0.52 \\
19 \\
3.1 \\
0.33 \\
3.4\end{array}$ & $\begin{array}{l}0.33 \\
0.22 \\
0.11 \\
0.03 \\
0.11\end{array}$ & $\begin{array}{r}0.16 \\
0.03 \\
0.21 \\
0.38 \\
\mathrm{e} 0.20\end{array}$ & $\begin{array}{l}\text { e } 0.10 \\
\text { e } 0.10 \\
\text { e } 0.10 \\
\text { e } 0.10 \\
\text { e } 0.10\end{array}$ & $\begin{array}{r}\mathrm{e} 0.10 \\
\mathrm{e} 0.10 \\
0.06 \\
0.08 \\
0.06\end{array}$ & $\begin{array}{l}0.08 \\
0.00 \\
0.15 \\
0.16 \\
0.17\end{array}$ & $\begin{array}{l}0.19 \\
0.16 \\
4.5 \\
0.40 \\
2.0\end{array}$ & $\begin{array}{l}0.28 \\
0.27 \\
0.21 \\
0.13 \\
0.17\end{array}$ & $\begin{array}{l}0.29 \\
0.46 \\
0.30 \\
0.52 \\
0.27\end{array}$ & $\begin{array}{l}0.21 \\
0.24 \\
0.22 \\
0.21 \\
0.17\end{array}$ & $\begin{array}{l}0.26 \\
0.23 \\
0.40 \\
0.36 \\
2.6\end{array}$ & $\begin{array}{l}0.15 \\
0.25 \\
0.26 \\
0.35 \\
0.28\end{array}$ \\
\hline $\begin{array}{l}11 \\
12 \\
13 \\
14 \\
15\end{array}$ & $\begin{array}{l}0.67 \\
0.27 \\
0.38 \\
0.25 \\
0.29\end{array}$ & $\begin{array}{l}0.27 \\
4.6 \\
2.2 \\
0.20 \\
0.09\end{array}$ & $\begin{array}{r}\mathrm{e} 0.20 \\
0.94 \\
\mathrm{e} 0.20 \\
0.10 \\
0.20\end{array}$ & $\begin{array}{l}0.00 \\
0.06 \\
0.16 \\
0.17 \\
0.39\end{array}$ & $\begin{array}{l}0.17 \\
0.19 \\
0.00 \\
0.11 \\
0.00\end{array}$ & $\begin{array}{l}0.18 \\
0.14 \\
0.32 \\
0.25 \\
0.28\end{array}$ & $\begin{array}{l}0.14 \\
0.05 \\
0.19 \\
0.24 \\
0.18\end{array}$ & $\begin{array}{l}0.21 \\
0.14 \\
0.17 \\
0.23 \\
0.09\end{array}$ & $\begin{array}{l}0.30 \\
0.23 \\
0.22 \\
0.29 \\
0.20\end{array}$ & $\begin{array}{l}0.95 \\
5.6 \\
0.26 \\
0.24 \\
6.9\end{array}$ & $\begin{array}{l}0.47 \\
0.24 \\
0.24 \\
0.17 \\
0.26\end{array}$ & $\begin{array}{l}0.73 \\
0.46 \\
0.27 \\
0.22 \\
0.22\end{array}$ \\
\hline $\begin{array}{l}16 \\
17 \\
18 \\
19 \\
20\end{array}$ & $\begin{array}{l}0.36 \\
0.48 \\
0.10 \\
0.08 \\
0.22\end{array}$ & $\begin{array}{l}0.20 \\
0.15 \\
0.20 \\
0.18 \\
0.13\end{array}$ & $\begin{array}{l}\text { e } 0.20 \\
\text { e } 0.20 \\
\text { e } 0.20 \\
\text { e } 0.10 \\
\text { e } 0.10\end{array}$ & $\begin{array}{l}0.16 \\
0.09 \\
0.00 \\
0.18 \\
0.65\end{array}$ & $\begin{array}{l}0.00 \\
0.12 \\
0.19 \\
0.38 \\
0.12\end{array}$ & $\begin{array}{l}0.41 \\
0.31 \\
0.28 \\
0.22 \\
0.19\end{array}$ & $\begin{array}{l}0.17 \\
0.09 \\
0.01 \\
0.06 \\
0.27\end{array}$ & $\begin{array}{l}0.01 \\
0.22 \\
0.71 \\
0.21 \\
0.26\end{array}$ & $\begin{array}{l}0.18 \\
0.24 \\
0.22 \\
0.24 \\
0.40\end{array}$ & $\begin{array}{l}0.35 \\
0.17 \\
0.50 \\
0.67 \\
0.41\end{array}$ & $\begin{array}{l}0.33 \\
0.19 \\
0.27 \\
0.35 \\
0.34\end{array}$ & $\begin{array}{c}0.27 \\
0.23 \\
0.34 \\
14 \\
1.5\end{array}$ \\
\hline $\begin{array}{l}21 \\
22 \\
23 \\
24 \\
25\end{array}$ & $\begin{array}{l}0.23 \\
0.23 \\
0.19 \\
0.18 \\
0.24\end{array}$ & $\begin{array}{l}0.25 \\
0.08 \\
0.08 \\
0.12 \\
0.24\end{array}$ & $\begin{array}{r}0.01 \\
0.21 \\
\mathrm{e} 0.20 \\
\mathrm{e} 0.20 \\
\mathrm{e} 0.20\end{array}$ & $\begin{array}{r}0.16 \\
\mathrm{e} 0.10 \\
\mathrm{e} 0.10 \\
\mathrm{e} 0.10 \\
0.35\end{array}$ & $\begin{array}{c}0.73 \\
0.06 \\
18 \\
5.0 \\
0.10\end{array}$ & $\begin{array}{l}0.17 \\
0.51 \\
0.63 \\
0.30 \\
0.16\end{array}$ & $\begin{array}{l}0.18 \\
0.18 \\
0.28 \\
0.08 \\
0.08\end{array}$ & $\begin{array}{l}0.17 \\
0.10 \\
0.14 \\
0.22 \\
0.22\end{array}$ & $\begin{array}{l}0.35 \\
0.35 \\
0.39 \\
0.31 \\
0.41\end{array}$ & $\begin{array}{l}0.33 \\
5.5 \\
47 \\
2.2 \\
10\end{array}$ & $\begin{array}{l}0.19 \\
0.36 \\
0.24 \\
0.28 \\
0.35\end{array}$ & $\begin{array}{l}0.34 \\
0.24 \\
0.23 \\
0.27 \\
0.14\end{array}$ \\
\hline $\begin{array}{l}26 \\
27 \\
28 \\
29 \\
30 \\
31\end{array}$ & $\begin{array}{l}0.11 \\
0.23 \\
0.25 \\
0.24 \\
0.18 \\
0.26\end{array}$ & $\begin{array}{r}0.20 \\
\mathrm{e} 0.10 \\
\mathrm{e} 0.10 \\
\mathrm{e} 0.10 \\
0.02 \\
---\end{array}$ & $\begin{array}{r}0.21 \\
\mathrm{e} 0.10 \\
0.00 \\
0.05 \\
\mathrm{e} 0.10 \\
\mathrm{e} 0.10\end{array}$ & $\begin{array}{r}\text { e0.20 } \\
\text { e } 0.10 \\
\text { e0.10 } \\
\text { e } 0.10 \\
\text { e0.10 } \\
0.10\end{array}$ & $\begin{array}{l}0.07 \\
0.07 \\
1.4 \\
0.04 \\
--- \\
---\end{array}$ & $\begin{array}{l}0.70 \\
0.13 \\
0.07 \\
0.20 \\
0.17 \\
0.23\end{array}$ & $\begin{array}{l}0.23 \\
0.18 \\
0.17 \\
0.22 \\
0.22 \\
---\end{array}$ & $\begin{array}{l}0.27 \\
0.21 \\
0.24 \\
0.13 \\
0.02 \\
0.25\end{array}$ & $\begin{array}{c}0.27 \\
0.49 \\
1.0 \\
12 \\
0.34 \\
---\end{array}$ & $\begin{array}{l}0.34 \\
2.1 \\
0.45 \\
0.36 \\
0.25 \\
0.30\end{array}$ & $\begin{array}{l}0.23 \\
0.25 \\
0.24 \\
0.27 \\
0.33 \\
0.24\end{array}$ & $\begin{array}{l}0.20 \\
0.17 \\
0.26 \\
0.27 \\
0.42 \\
---\end{array}$ \\
\hline $\begin{array}{l}\text { TOTAL } \\
\text { MEAN } \\
\text { MAX } \\
\text { MIN } \\
\text { AC-FT }\end{array}$ & $\begin{array}{c}34.48 \\
1.11 \\
19 \\
0.08 \\
68\end{array}$ & $\begin{array}{c}11.43 \\
0.38 \\
4.6 \\
0.02 \\
23\end{array}$ & $\begin{array}{c}5.97 \\
0.19 \\
0.94 \\
0.00 \\
12\end{array}$ & $\begin{array}{l}4.32 \\
0.14 \\
0.65 \\
0.00 \\
8.6\end{array}$ & $\begin{array}{c}27.95 \\
0.96 \\
18 \\
0.00 \\
55\end{array}$ & $\begin{array}{c}22.18 \\
0.72 \\
13 \\
0.00 \\
44\end{array}$ & $\begin{array}{c}47.34 \\
1.58 \\
31 \\
0.01 \\
94\end{array}$ & $\begin{array}{c}6.16 \\
0.20 \\
0.71 \\
0.00 \\
12\end{array}$ & $\begin{array}{c}21.80 \\
0.73 \\
12 \\
0.18 \\
43\end{array}$ & $\begin{array}{c}87.23 \\
2.81 \\
47 \\
0.15 \\
173\end{array}$ & $\begin{array}{c}12.41 \\
0.40 \\
2.6 \\
0.17 \\
25\end{array}$ & $\begin{array}{c}24.12 \\
0.80 \\
14 \\
0.14 \\
48\end{array}$ \\
\hline \multicolumn{13}{|c|}{ STATISTICS OF MONTHLY MEAN DATA FOR WATER YEARS 1997 - 2004, BY WATER YEAR (WY) } \\
\hline $\begin{array}{l}\text { MEAN } \\
\text { MAX } \\
\text { (WY) } \\
\text { MIN } \\
\text { (WY) }\end{array}$ & $\begin{array}{r}1.20 \\
2.39 \\
(2001) \\
0.54 \\
(1998)\end{array}$ & $\begin{array}{r}0.57 \\
0.76 \\
(2001) \\
0.38 \\
(2004)\end{array}$ & $\begin{array}{r}0.36 \\
0.58 \\
(2002) \\
0.10 \\
(1997)\end{array}$ & $\begin{array}{r}0.33 \\
0.52 \\
(2002) \\
0.14 \\
(2004)\end{array}$ & $\begin{array}{r}0.53 \\
0.96 \\
(2004) \\
0.15 \\
(1997)\end{array}$ & $\begin{array}{r}0.93 \\
1.97 \\
(1998) \\
0.26 \\
(1997)\end{array}$ & $\begin{array}{r}0.86 \\
1.58 \\
(2004) \\
0.43 \\
(2003)\end{array}$ & $\begin{array}{r}0.59 \\
1.06 \\
(1998) \\
0.20 \\
(2004)\end{array}$ & $\begin{array}{r}0.90 \\
1.65 \\
(2000) \\
0.35 \\
(2003)\end{array}$ & $\begin{array}{r}1.54 \\
2.81 \\
(2004) \\
0.25 \\
(2003)\end{array}$ & $\begin{array}{r}1.35 \\
2.49 \\
(1999) \\
0.40 \\
(2004)\end{array}$ & $\begin{array}{r}1.04 \\
2.44 \\
(1997) \\
0.51 \\
(2003)\end{array}$ \\
\hline
\end{tabular}

\section{SUMMARY STATISTICS}

ANNUAL TOTAL

ANNUAL MEAN

HIGHEST ANNUAL MEAN

LOWEST ANNUAL MEAN

HIGHEST DAILY MEAN

LOWEST DAILY MEAN

MAXIMUM PEAK FLOW

MAXIMUM PEAK STAGE

ANNUAL RUNOFF (AC-FT)

10 PERCENT EXCEEDS

50 PERCENT EXCEEDS

EXCEEDS

\section{FOR 2003 CALENDAR YEAR}

$\begin{array}{cc}203.65 & \\ 0.56 & \\ & \\ 19 & \text { Oct 7 } \\ 0.00 & \text { Dec 28 } \\ 0.08 & \text { Jan 29 } \\ & \\ 404 & \\ 0.75 & \\ 0.29 & \\ 0.10 & \end{array}$

\section{FOR 2004 WATER YEAR}

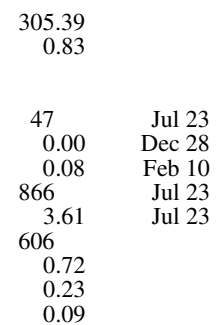

WATER YEARS 1997 - 2004

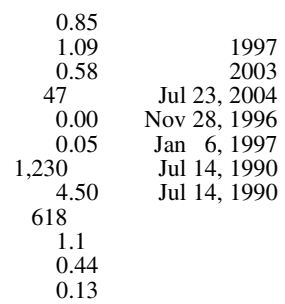

(+)Total precipitation accumulation, in inches.

e Estimated 


\section{EMBUDO ARROYO AT ALBUQUERQUE, NEW MEXICO}

\section{STATION ANALYSIS}

\section{WATER YEAR 2004}

Equipment.--This station was established on October 2, 1998. An electronic datalogger and pressure transducer is housed in a metal 2.5- X 2.5- X 6-foot shelter anchored to a concrete pad on the left bank of the concrete-lined portion of the channel, approximately 90 feet upstream from the Monte Largo bridge. On September 12, 2001, an ISCO model 6712 automatic water-quality sampler was installed and housed in a separate metal shelter immediately adjacent to the gage shelter. The site is located east of Tramway Boulevard, between Indian School Road and Rover Street, on Albuquerque's far east side. The 30-foot-long orifice line is anchored immediately upstream from the 1-foot-wide, 26-inch-high concrete wall that spans the entire channel. A 12-inch-wide, Ushaped notch cut into the concrete wall acts as the low-flow control. An outside staff gage, with an attached crest-stage gage, is mounted approximately 24 inches upstream from the orifice and is the reference gage. The elevation of the crest-stage gage lower cap is 1.66 feet above the point of zero flow (PZF). High-water measurements are computed by indirect methods. Low-water wading measurements are made in the vicinity of the gage.

Gage-Height Record.-- The recorder gave a complete and satisfactory record during water year 2004. The recorder will only sense water levels above a stage of 1.05 feet, because the orifice is mounted 0.05 foot above the PZF. This prevents sediment from covering the orifice during flow events. At a stage of 1.05 feet, the computed discharge is 0.05 ccubic feet per second. The gage was shut down during the winter period December 5, 2003 to March 4, 2004. A few hours before the recorder was started up on March 4, a flow event occurred which left a high-water mark on the outside staff. This peak gage height was the basis for an estimated hydrograph that was graphed in the database and used to compute an estimated daily mean discharge.

Rating.--The channel below the gage orifice is trapezoidal shaped and concrete-lined. The bottom width is 39 feet. The channel continues straight downstream for 120 feet before gently bending toward the left bank after passing under the Monte Largo bridge. Upstream from the gage orifice, the channel consists of a wide, flat slope for approximately 50 feet and its bottom material is coarse sand. This approach immediately upstream from the gage is a settling area for stream sediments after passing over a 10-foot-high, concrete, stair-stepped wall. A 26-inch-high concrete wall separates the concrete-lined portion of the channel downstream and the natural channel upstream. A 1-foot wide notch cut into the concrete wall is the low-flow control. The concrete wall is 12 inches thick and flat-topped, so flows breaching this wall are effectively controlled by this broad-crested weir. For rating development purposes, the 1-foot-wide notch was treated as a one-foot-long box culvert in theoretical discharge computations. The rating breaks sharply to the right, at gage heights exceeding 3.17 feet, when flows begin to breach the entire concrete wall. Broad-crested weir flow equations were used to compute this portion of the rating. An offset of 2.5 was used for this middle section.

When flow depths exceed 1.5 feet above the wall, or gage heights over approximately 4.77 feet, the concrete wall acts as a sharp-crested weir, because the turbulence caused by the upstream face 
of the vertical wall clears the downstream face, effectively converting flows to sharpcrested weir type. The upper section of the rating breaks even further to the right than the middle portion. Flows downstream from the concrete control wall are supercritical, but are subcritical in the approach section.

The extremely flashy nature of this stream makes it difficult to obtain discharge measurements, so the theoretical rating is most reliable until more measurements are available. In water year 2004, 21 site inspections were made; none during a time of flow. The peak stage and discharge recorded for water year 2004 was 3.31 feet and 16 cubic feet per second, respectively, on August4.

Discharge.--Discharges were calculated by applying rating 1.0 directly. The point of zero flow (PZF) is a gage height of 1.00 feet, but zero flow is also computed for any gage heights below 1.06 feet because the orifice is mounted 0.05 feet above the PZF.

No stations are available for comparison purposes. 
RIO GRANDE BASIN

08329720 EMBUDO ARROYO AT ALBUQUERQUE, NM

LOCATION.--Lat $35^{\circ} 06^{\prime} 08^{\prime \prime}$, long 106 $29^{\prime} 33^{\prime \prime}$, in NW $1 /{ }_{4} \mathrm{NE}^{1 /}{ }_{4}$ sec.14, T.10 N., R.4 E., Bernalillo County, Hydrologic Unit 13020203 , on left bank of concrete-lined channel, approximately $90 \mathrm{ft}$ upstream from Monte Largo bridge over Embudo Arroyo, between Indian School Rd to the south and Rover St to the north in Albuquerque.

DRAINAGE AREA.--3.8 $\mathrm{mi}^{2}$.

PERIOD OF RECORD.--October 1998 to current year.

GAGE.--Water-stage recorder, crest-stage gage, and concrete weir control. Elevation of gage is 5,925 ft above National Geodetic Vertical Datum of 1929 , from topographic map.

REMARKS.--Records good. Recording rain gage located in drainage basin, approximately 1 mi upstream. Site used for gathering water-quality data for undeveloped upper drainage basin, which represents undeveloped foothill east of Albuquerque.

DISCHARGE, CUBIC FEET PER SECOND

WATER YEAR OCTOBER 2003 TO SEPTEMBER 2004

\begin{tabular}{|c|c|c|c|c|c|c|c|c|c|c|c|c|}
\hline DAY & OCT & NOV & DEC & JAN & FEB & MAR & APR & MAY & JUN & JUL & AUG & SEP \\
\hline $\begin{array}{l}1 \\
2 \\
3 \\
4 \\
5\end{array}$ & $\begin{array}{l}0.00 \\
0.00 \\
0.00 \\
0.00 \\
0.00\end{array}$ & $\begin{array}{l}0.00 \\
0.00 \\
0.00 \\
0.00 \\
0.00\end{array}$ & $\begin{array}{l}0.00 \\
0.00 \\
0.00 \\
0.00 \\
0.00\end{array}$ & $\begin{array}{l}--- \\
--- \\
-- \\
--- \\
---\end{array}$ & $\begin{array}{l}--- \\
--- \\
--- \\
--- \\
--\end{array}$ & $\begin{array}{r}--- \\
--- \\
--- \\
\mathrm{e} 0.13 \\
0.03\end{array}$ & $\begin{array}{l}0.00 \\
0.00 \\
0.12 \\
0.01 \\
0.00\end{array}$ & $\begin{array}{l}0.00 \\
0.00 \\
0.00 \\
0.00 \\
0.00\end{array}$ & $\begin{array}{l}0.00 \\
0.00 \\
0.00 \\
0.00 \\
0.00\end{array}$ & $\begin{array}{l}0.00 \\
0.00 \\
0.00 \\
0.00 \\
0.00\end{array}$ & $\begin{array}{l}0.00 \\
0.00 \\
0.00 \\
0.41 \\
0.00\end{array}$ & $\begin{array}{l}0.00 \\
0.00 \\
0.00 \\
0.00 \\
0.00\end{array}$ \\
\hline $\begin{array}{r}6 \\
7 \\
8 \\
9 \\
10\end{array}$ & $\begin{array}{l}0.00 \\
0.01 \\
0.00 \\
0.00 \\
0.01\end{array}$ & $\begin{array}{l}0.00 \\
0.00 \\
0.00 \\
0.00 \\
0.00\end{array}$ & $\begin{array}{l}--- \\
--- \\
--- \\
--- \\
--\end{array}$ & $\begin{array}{l}--- \\
--- \\
--- \\
--- \\
---\end{array}$ & $\begin{array}{l}--- \\
--- \\
--- \\
--- \\
---\end{array}$ & $\begin{array}{l}0.00 \\
0.00 \\
0.00 \\
0.00 \\
0.00\end{array}$ & $\begin{array}{l}0.00 \\
0.00 \\
0.00 \\
0.00 \\
0.00\end{array}$ & $\begin{array}{l}0.00 \\
0.00 \\
0.00 \\
0.00 \\
0.00\end{array}$ & $\begin{array}{l}0.00 \\
0.00 \\
0.00 \\
0.00 \\
0.00\end{array}$ & $\begin{array}{l}0.00 \\
0.00 \\
0.00 \\
0.00 \\
0.00\end{array}$ & $\begin{array}{l}0.00 \\
0.00 \\
0.00 \\
0.00 \\
0.00\end{array}$ & $\begin{array}{l}0.00 \\
0.00 \\
0.00 \\
0.00 \\
0.00\end{array}$ \\
\hline $\begin{array}{l}11 \\
12 \\
13 \\
14 \\
15\end{array}$ & $\begin{array}{l}0.00 \\
0.00 \\
0.00 \\
0.00 \\
0.00\end{array}$ & $\begin{array}{l}0.00 \\
0.00 \\
0.00 \\
0.00 \\
0.00\end{array}$ & $\begin{array}{l}--- \\
-- \\
--- \\
--- \\
--\end{array}$ & $\begin{array}{l}--- \\
-- \\
-- \\
--- \\
---\end{array}$ & $\begin{array}{l}--- \\
--- \\
--- \\
--- \\
---\end{array}$ & $\begin{array}{l}0.00 \\
0.00 \\
0.00 \\
0.00 \\
0.00\end{array}$ & $\begin{array}{l}0.00 \\
0.00 \\
0.00 \\
0.00 \\
0.00\end{array}$ & $\begin{array}{l}0.00 \\
0.00 \\
0.00 \\
0.00 \\
0.00\end{array}$ & $\begin{array}{l}0.00 \\
0.00 \\
0.00 \\
0.00 \\
0.00\end{array}$ & $\begin{array}{l}0.00 \\
0.00 \\
0.00 \\
0.02 \\
0.00\end{array}$ & $\begin{array}{l}0.00 \\
0.00 \\
0.00 \\
0.00 \\
0.00\end{array}$ & $\begin{array}{l}0.00 \\
0.00 \\
0.00 \\
0.00 \\
0.00\end{array}$ \\
\hline $\begin{array}{l}16 \\
17 \\
18 \\
19 \\
20\end{array}$ & $\begin{array}{l}0.00 \\
0.00 \\
0.00 \\
0.00 \\
0.00\end{array}$ & $\begin{array}{l}0.00 \\
0.00 \\
0.00 \\
0.00 \\
0.00\end{array}$ & $\begin{array}{l}--- \\
-- \\
--- \\
--- \\
--\end{array}$ & $\begin{array}{l}--- \\
-- \\
--- \\
--- \\
---\end{array}$ & $\begin{array}{l}--- \\
--- \\
--- \\
--- \\
---\end{array}$ & $\begin{array}{l}0.00 \\
0.00 \\
0.00 \\
0.00 \\
0.00\end{array}$ & $\begin{array}{l}0.00 \\
0.00 \\
0.00 \\
0.00 \\
0.00\end{array}$ & $\begin{array}{l}0.00 \\
0.00 \\
0.00 \\
0.00 \\
0.00\end{array}$ & $\begin{array}{l}0.00 \\
0.00 \\
0.00 \\
0.00 \\
0.00\end{array}$ & $\begin{array}{l}0.00 \\
0.00 \\
0.00 \\
0.00 \\
0.00\end{array}$ & $\begin{array}{l}0.00 \\
0.00 \\
0.00 \\
0.00 \\
0.00\end{array}$ & $\begin{array}{l}0.00 \\
0.00 \\
0.00 \\
0.00 \\
0.00\end{array}$ \\
\hline $\begin{array}{l}21 \\
22 \\
23 \\
24 \\
25\end{array}$ & $\begin{array}{l}0.00 \\
0.00 \\
0.00 \\
0.00 \\
0.00\end{array}$ & $\begin{array}{l}0.00 \\
0.00 \\
0.00 \\
0.00 \\
0.00\end{array}$ & $\begin{array}{l}--- \\
--- \\
--- \\
-- \\
--\end{array}$ & $\begin{array}{l}--- \\
--- \\
--- \\
-- \\
--\end{array}$ & $\begin{array}{l}--- \\
--- \\
--- \\
--- \\
---\end{array}$ & $\begin{array}{l}0.00 \\
0.00 \\
0.00 \\
0.00 \\
0.00\end{array}$ & $\begin{array}{l}0.00 \\
0.00 \\
0.00 \\
0.00 \\
0.00\end{array}$ & $\begin{array}{l}0.00 \\
0.00 \\
0.00 \\
0.00 \\
0.00\end{array}$ & $\begin{array}{l}0.00 \\
0.00 \\
0.00 \\
0.00 \\
0.00\end{array}$ & $\begin{array}{l}0.00 \\
0.00 \\
0.00 \\
0.00 \\
0.00\end{array}$ & $\begin{array}{l}0.00 \\
0.00 \\
0.00 \\
0.00 \\
0.00\end{array}$ & $\begin{array}{l}0.00 \\
0.00 \\
0.00 \\
0.00 \\
0.00\end{array}$ \\
\hline $\begin{array}{l}26 \\
27 \\
28 \\
29 \\
30 \\
31\end{array}$ & $\begin{array}{l}0.00 \\
0.00 \\
0.00 \\
0.00 \\
0.00 \\
0.00\end{array}$ & $\begin{array}{l}0.00 \\
0.00 \\
0.00 \\
0.00 \\
0.00 \\
---\end{array}$ & $\begin{array}{l}--- \\
--- \\
--- \\
--- \\
--- \\
---\end{array}$ & $\begin{array}{l}--- \\
--- \\
--- \\
--- \\
--- \\
---\end{array}$ & $\begin{array}{l}--- \\
--- \\
--- \\
-- \\
--- \\
---\end{array}$ & $\begin{array}{l}0.00 \\
0.00 \\
0.00 \\
0.00 \\
0.00 \\
0.00\end{array}$ & $\begin{array}{l}0.00 \\
0.00 \\
0.00 \\
0.00 \\
0.00 \\
---\end{array}$ & $\begin{array}{l}0.00 \\
0.00 \\
0.00 \\
0.00 \\
0.00 \\
0.00\end{array}$ & $\begin{array}{c}0.00 \\
0.00 \\
0.03 \\
0.00 \\
0.00 \\
---\end{array}$ & $\begin{array}{l}0.00 \\
0.01 \\
0.00 \\
0.00 \\
0.00 \\
0.00\end{array}$ & $\begin{array}{l}0.00 \\
0.00 \\
0.00 \\
0.00 \\
0.00 \\
0.00\end{array}$ & $\begin{array}{c}0.00 \\
0.00 \\
0.00 \\
0.00 \\
0.00 \\
---\end{array}$ \\
\hline $\begin{array}{l}\text { TOTAL } \\
\text { MEAN } \\
\text { MAX } \\
\text { MIN } \\
\text { AC-FT }\end{array}$ & $\begin{array}{l}0.02 \\
0.00 \\
0.01 \\
0.00 \\
0.04\end{array}$ & $\begin{array}{l}0.00 \\
0.00 \\
0.00 \\
0.00 \\
0.00\end{array}$ & $\begin{array}{l}--- \\
--- \\
--- \\
--- \\
---\end{array}$ & $\begin{array}{l}--- \\
-- \\
--- \\
--- \\
---\end{array}$ & $\begin{array}{l}--- \\
--- \\
-- \\
-- \\
---\end{array}$ & $\begin{array}{l}--- \\
--- \\
--- \\
-- \\
--\end{array}$ & $\begin{array}{l}0.13 \\
0.00 \\
0.12 \\
0.00 \\
0.3\end{array}$ & $\begin{array}{l}0.00 \\
0.00 \\
0.00 \\
0.00 \\
0.00\end{array}$ & $\begin{array}{l}0.03 \\
0.00 \\
0.03 \\
0.00 \\
0.06\end{array}$ & $\begin{array}{l}0.03 \\
0.00 \\
0.02 \\
0.00 \\
0.06\end{array}$ & $\begin{array}{l}0.41 \\
0.01 \\
0.41 \\
0.00 \\
0.8\end{array}$ & $\begin{array}{l}0.00 \\
0.00 \\
0.00 \\
0.00 \\
0.00\end{array}$ \\
\hline \multicolumn{13}{|c|}{ STATISTICS OF MONTHLY MEAN DATA FOR WATER YEARS 1999 - 2004, BY WATER YEAR (WY) } \\
\hline $\begin{array}{l}\text { MEAN } \\
\text { MAX } \\
\text { (WY) } \\
\text { MIN } \\
\text { (WY) }\end{array}$ & $\begin{array}{r}0.00 \\
0.01 \\
(2001) \\
0.00 \\
(2000)\end{array}$ & $\begin{array}{r}0.00 \\
0.00 \\
(2001) \\
0.00 \\
(1999)\end{array}$ & $\begin{array}{r}0.00 \\
0.00 \\
(1999) \\
0.00 \\
(1999)\end{array}$ & $\begin{array}{r}0.00 \\
0.00 \\
(1999) \\
0.00 \\
(1999)\end{array}$ & $\begin{array}{r}0.00 \\
0.00 \\
(1999) \\
0.00 \\
(1999)\end{array}$ & $\begin{array}{r}0.00 \\
0.00 \\
(2003) \\
0.00 \\
(1999)\end{array}$ & $\begin{array}{r}0.00 \\
0.00 \\
(2004) \\
0.00 \\
(1999)\end{array}$ & $\begin{array}{r}0.00 \\
0.00 \\
(1999) \\
0.00 \\
(1999)\end{array}$ & $\begin{array}{r}0.00 \\
0.00 \\
(2000) \\
0.00 \\
(1999)\end{array}$ & $\begin{array}{r}0.00 \\
0.00 \\
(2000) \\
0.00 \\
(2002)\end{array}$ & $\begin{array}{r}0.01 \\
0.01 \\
(1999) \\
0.00 \\
(2002)\end{array}$ & $\begin{array}{r}0.00 \\
0.00 \\
(2001) \\
0.00 \\
(1999)\end{array}$ \\
\hline
\end{tabular}

SUMMARY STATISTICS

WATER YEARS 1999 - 2004

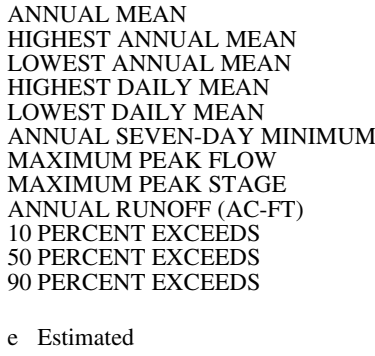




\section{NORTH FLOODWAY CHANNEL AT ALBUQUERQUE, NEW MEXICO}

\section{STATION ANALYSIS}

\section{WATER YEAR 2004}

Equipment.--A pressure transducer and electronic datalogger with a speech/telephone modem were installed on July 22, 1999 and are housed in a metal 5- x 5-foot walk-in shelter on the right bank of the concrete-lined channel. A tipping-bucket rain gage was installed on the roof of the shelter on July 23, 1999 and is also recorded by the datalogger. Both water-stage and rainfall data are recorded on 5-minute intervals. An outside staff gage is painted on the inclined, channel side-slopes and is the reference gage. Since July 26, 2001, this site has been a test location for a prototype radar stage sensor developed by the USGS Hydrologic Instrumentation Facility (HIF). The radar is housed in a metal shelter mounted to the hand railing of the Candelaria Boulevard bridge and transmits data by radio to the gage house and datalogger.

Gage-height record.--The recorder, referenced to the outside staff gage, gave a complete and satisfactory record for water year 2004, except when the orifice was covered with ice on November 22-25, December 9-11, and 13-31, 2003, and January 1-11, 22-28, and February 115,2004 . All estimated mean daily discharges were based on flows before and after the affected period, flow records at the downstream Alameda gage (08329900) and upstream Campus Wash gage (08329700), and precipitation records. Instantaneous discharges remained near base flow (1.0 to 2.0 cubic feet per second) for all estimates except the rainy day of January 25 , so mean daily discharges were not significantly affected. This station had previously been closed for winter months, but since water year 2000 has been operated all year.

Rating.--The control for the station is the concrete-lined channel. The bottom width of the channel is 30 feet. The slope of the sidewalls is approximatley 27 degrees from horizontal. The depth of the channel at this location is about 30 feet and its top width is $137 \mathrm{feet}$. The channel slope at this site is much less (0.0009 foot per foot) than the downstream gage near Alameda (approximately 0.0047 foot per foot). Flows are subcritical for all stages at this location, but the Alameda gage has supercritical flows at most gage heights.

During water year 2004, 37 inspections were made at the gaging station. Only extremely lowflow measurements are attempted at this location due to the dangers of floating debris during most flows. The theoretical rating for this uniformly-shaped, concrete-lined channel is considered more accurate than individual measurements.

Rating 1.0, effective in previous years, was replaced by a new rating, 2.0, in water year 2001. The old rating appeared to have been based on four low-flow discharge measurements. The channel was re-surveyed in December, 2001 and a step-backwater analysis was completed for this site using the USGS Water Surface Profile (WSPRO) software. The analysis assumed a Manning's n-value of 0.016 for channel bottom roughness, prorated to 0.014 over 4 feet of depth. Slight differences between the two ratings are apparent, especially at higher discharges. The old rating did not compute discharges for gage heights under 0.30 foot $(11.4$ cubic feet per second), whereas the new rating, 2.0, computes a discharge for all stages above the point of zero flow (0.00-foot gage height). Because the base flow at this location is approximately 0.5 to $3.0 \mathrm{cfs}$. year-round, the new rating computes a significantly larger volume of base-flow passing this gage each year and returning to the Rio Grande. All previous years' records (since 1982) containing have been revised using the new rating.

Discharge--Discharges were computed for water year 2004 using the new rating curve 2.0. The channel in this reach creates velocities that keep the channel bottom fairly clean, and for this reason, no shifting should occur. Discharges less than 11.4 cubic feet per second (gage heights 
less than 0.30 foot) were reported as zero flow prior to water year 2001 and are generally not the result of rainfall runoff. Beginning in water year 2001, all discharges above the PZF have been computed. The maximum stage during water year 2004 was 9.30 feet, corresponding to a discharge of 4,880 cubic feet per second on July 23. 
LOCATION.--Lat $35^{\circ} 07^{\prime} 03^{\prime \prime}$, long $106^{\circ} 36^{\prime} 42^{\prime \prime}$, in SE $1 / \quad{ }_{4}$ sec.3, T.10 N., R.3 E., Bernalillo County, Hydrologic Unit 13020203 , on right bank of concrete lined drainage channel, $300 \mathrm{ft}$ downstream (north) of bridge on Candelaria Boulevard NE, and 3,000 ft downstream from confluence of Campus Wash and Embudo Arroyo in Albuquerque.

DRAINAGE AREA.--40.0 $\mathrm{mi}^{2}$.

PERIOD OF RECORD.--May 1982 to September 1999 (seasonal records). October 1999 to current year.

GAGE.--Water-stage recorder and recording tipping-bucket rain gage with 0.01-in. increment, and concrete lined channel. Elevation of gage is $5,110 \mathrm{ft}$ above National Geodetic Vertical Datum of 1929, from topographic map.

REMARKS.--Records good except for those estimated, which are poor. Prior to water year 2001, some minor streamflow may exist on days when daily mean discharges have been recorded as zero due to the sensitivity limits of the streamflow monitoring equipment. See tabulation below for monthly precipitation, in inches.

DISCHARGE, CUBIC FEET PER SECOND

WATER YEAR OCTOBER 2003 TO SEPTEMBER 2004 DAILY MEAN VALUES

\begin{tabular}{|c|c|c|c|c|c|c|c|c|c|c|c|c|}
\hline DAY & OCT & NOV & DEC & JAN & FEB & MAR & APR & MAY & JUN & JUL & AUG & SEP \\
\hline $\begin{array}{l}1 \\
2 \\
3 \\
4 \\
5\end{array}$ & $\begin{array}{l}0.81 \\
0.92 \\
1.6 \\
2.4 \\
1.3\end{array}$ & $\begin{array}{l}3.4 \\
2.9 \\
2.0 \\
2.5 \\
2.2\end{array}$ & $\begin{array}{l}2.0 \\
2.0 \\
2.3 \\
2.5 \\
2.4\end{array}$ & $\begin{array}{l}\mathrm{e} 1.5 \\
\mathrm{e} 1.5 \\
\mathrm{e} 1.5 \\
\mathrm{e} 1.5 \\
\mathrm{e} 1.5\end{array}$ & $\begin{array}{l}\mathrm{e} 1.5 \\
\mathrm{e} 1.5 \\
\mathrm{e} 1.5 \\
\mathrm{e} 1.5 \\
\mathrm{e} 1.5\end{array}$ & $\begin{array}{r}1.5 \\
2.6 \\
3.6 \\
144 \\
13\end{array}$ & $\begin{array}{c}1.4 \\
27 \\
255 \\
39 \\
1.7\end{array}$ & $\begin{array}{l}1.4 \\
1.2 \\
1.1 \\
1.5 \\
0.90\end{array}$ & $\begin{array}{l}1.0 \\
1.1 \\
1.2 \\
1.3 \\
1.4\end{array}$ & $\begin{array}{l}1.6 \\
1.3 \\
1.2 \\
1.4 \\
1.3\end{array}$ & $\begin{array}{c}1.2 \\
6.1 \\
3.0 \\
145 \\
2.8\end{array}$ & $\begin{array}{l}1.2 \\
1.2 \\
0.98 \\
6.8 \\
1.5\end{array}$ \\
\hline $\begin{array}{r}6 \\
7 \\
8 \\
9 \\
10\end{array}$ & $\begin{array}{c}1.2 \\
193 \\
39 \\
2.2 \\
24\end{array}$ & $\begin{array}{l}2.3 \\
2.1 \\
2.9 \\
3.1 \\
2.2\end{array}$ & $\begin{array}{r}2.5 \\
2.7 \\
2.1 \\
\mathrm{e} 2.0 \\
\mathrm{e} 2.0\end{array}$ & $\begin{array}{l}\mathrm{e} 1.5 \\
\mathrm{e} 1.5 \\
\mathrm{e} 1.5 \\
\mathrm{e} 1.5 \\
\mathrm{e} 1.5\end{array}$ & $\begin{array}{l}\mathrm{e} 1.5 \\
\mathrm{e} 1.5 \\
\mathrm{e} 1.5 \\
\mathrm{e} 1.5 \\
\mathrm{e} 1.5\end{array}$ & $\begin{array}{l}2.3 \\
1.8 \\
1.3 \\
2.0 \\
1.3\end{array}$ & $\begin{array}{c}1.4 \\
1.4 \\
56 \\
7.8 \\
23\end{array}$ & $\begin{array}{l}3.7 \\
4.4 \\
1.5 \\
1.3 \\
1.8\end{array}$ & $\begin{array}{l}1.2 \\
1.2 \\
1.1 \\
1.4 \\
1.2\end{array}$ & $\begin{array}{l}1.1 \\
1.3 \\
2.2 \\
1.4 \\
1.0\end{array}$ & $\begin{array}{l}1.7 \\
1.7 \\
0.98 \\
1.1 \\
40\end{array}$ & $\begin{array}{l}0.89 \\
0.83 \\
0.91 \\
0.90 \\
0.86\end{array}$ \\
\hline $\begin{array}{l}11 \\
12 \\
13 \\
14 \\
15\end{array}$ & $\begin{array}{l}7.6 \\
3.8 \\
2.3 \\
2.0 \\
1.9\end{array}$ & $\begin{array}{c}2.3 \\
72 \\
27 \\
2.3 \\
2.6\end{array}$ & $\begin{array}{r}\text { e2.0 } \\
7.6 \\
\text { e2.0 } \\
\text { e2.0 } \\
\text { e2.0 }\end{array}$ & $\begin{array}{r}\mathrm{e} 2.0 \\
1.8 \\
2.0 \\
2.0 \\
2.3\end{array}$ & $\begin{array}{l}\mathrm{e} 2.0 \\
\mathrm{e} 1.5 \\
\mathrm{e} 1.5 \\
\mathrm{e} 1.5 \\
\mathrm{e} 2.0\end{array}$ & $\begin{array}{l}1.3 \\
1.8 \\
1.7 \\
1.6 \\
1.2\end{array}$ & $\begin{array}{l}3.2 \\
1.4 \\
1.1 \\
1.4 \\
3.0\end{array}$ & $\begin{array}{l}1.1 \\
2.9 \\
1.1 \\
1.2 \\
1.3\end{array}$ & $\begin{array}{l}1.2 \\
1.4 \\
1.6 \\
3.5 \\
1.2\end{array}$ & $\begin{array}{c}15 \\
54 \\
2.1 \\
9.3 \\
75\end{array}$ & $\begin{array}{l}1.4 \\
1.9 \\
1.5 \\
1.1 \\
0.98\end{array}$ & $\begin{array}{l}1.1 \\
1.4 \\
0.94 \\
1.1 \\
0.87\end{array}$ \\
\hline $\begin{array}{l}16 \\
17 \\
18 \\
19 \\
20\end{array}$ & $\begin{array}{l}2.8 \\
2.3 \\
2.3 \\
2.7 \\
2.0\end{array}$ & $\begin{array}{l}3.6 \\
3.1 \\
2.7 \\
2.8 \\
2.4\end{array}$ & $\begin{array}{l}\text { e2.0 } \\
\text { e2.0 } \\
\text { e2.0 } \\
\text { e2.0 } \\
\text { e1.5 }\end{array}$ & $\begin{array}{l}2.0 \\
2.2 \\
2.7 \\
2.3 \\
6.1\end{array}$ & $\begin{array}{l}1.9 \\
1.7 \\
1.5 \\
1.7 \\
1.6\end{array}$ & $\begin{array}{l}1.4 \\
1.5 \\
1.5 \\
1.4 \\
1.7\end{array}$ & $\begin{array}{l}1.4 \\
1.3 \\
1.3 \\
1.1 \\
1.4\end{array}$ & $\begin{array}{l}1.2 \\
1.2 \\
1.5 \\
1.1 \\
1.0\end{array}$ & $\begin{array}{l}1.7 \\
2.1 \\
1.3 \\
1.2 \\
1.3\end{array}$ & $\begin{array}{l}3.6 \\
1.9 \\
2.4 \\
2.4 \\
9.7\end{array}$ & $\begin{array}{l}1.3 \\
0.96 \\
1.1 \\
1.7 \\
1.4\end{array}$ & $\begin{array}{c}0.93 \\
0.93 \\
1.4 \\
122 \\
16\end{array}$ \\
\hline $\begin{array}{l}21 \\
22 \\
23 \\
24 \\
25\end{array}$ & $\begin{array}{l}1.9 \\
1.9 \\
2.1 \\
2.1 \\
2.7\end{array}$ & $\begin{array}{r}2.0 \\
\mathrm{e} 2.0 \\
\mathrm{e} 2.0 \\
\mathrm{e} 2.0 \\
\mathrm{e} 2.0\end{array}$ & $\begin{array}{l}\mathrm{e} 1.5 \\
\mathrm{e} 1.5 \\
\mathrm{e} 1.5 \\
\mathrm{e} 1.5 \\
\mathrm{e} 1.5\end{array}$ & $\begin{array}{r}2.2 \\
\mathrm{e} 2.0 \\
\mathrm{e} 2.0 \\
\mathrm{e} 2.0 \\
\mathrm{e} 5.0\end{array}$ & $\begin{array}{c}8.4 \\
3.7 \\
185 \\
59 \\
1.3\end{array}$ & $\begin{array}{l}1.5 \\
1.3 \\
2.0 \\
2.6 \\
1.4\end{array}$ & $\begin{array}{l}3.0 \\
0.86 \\
1.1 \\
1.5 \\
1.1\end{array}$ & $\begin{array}{l}1.4 \\
1.3 \\
1.1 \\
1.2 \\
1.1\end{array}$ & $\begin{array}{l}1.1 \\
2.9 \\
1.7 \\
1.5 \\
1.4\end{array}$ & $\begin{array}{c}1.9 \\
51 \\
261 \\
8.2 \\
91\end{array}$ & $\begin{array}{l}1.8 \\
1.8 \\
1.1 \\
1.1 \\
1.0\end{array}$ & $\begin{array}{l}1.4 \\
1.5 \\
1.2 \\
1.1 \\
1.3\end{array}$ \\
\hline $\begin{array}{l}26 \\
27 \\
28 \\
29 \\
30 \\
31\end{array}$ & $\begin{array}{l}2.9 \\
2.2 \\
2.3 \\
2.1 \\
2.0 \\
2.0\end{array}$ & $\begin{array}{l}2.5 \\
2.4 \\
2.2 \\
2.7 \\
3.2 \\
---\end{array}$ & $\begin{array}{l}\text { e1.5 } \\
\text { e1.5 } \\
\text { e1.5 } \\
\text { e1.5 } \\
\text { e1.5 } \\
\text { e1.5 }\end{array}$ & $\begin{array}{r}\mathrm{e} 2.0 \\
\mathrm{e} 2.0 \\
\mathrm{e} 2.0 \\
1.4 \\
2.2 \\
2.2\end{array}$ & $\begin{array}{c}1.2 \\
1.1 \\
15 \\
1.7 \\
--- \\
---\end{array}$ & $\begin{array}{l}1.5 \\
1.4 \\
1.6 \\
1.5 \\
1.3 \\
1.3\end{array}$ & $\begin{array}{l}0.98 \\
0.95 \\
1.2 \\
0.86 \\
1.0 \\
---\end{array}$ & $\begin{array}{l}1.2 \\
1.2 \\
1.1 \\
0.98 \\
1.4 \\
1.1\end{array}$ & $\begin{array}{l}19 \\
2.1 \\
20 \\
87 \\
2.5 \\
---\end{array}$ & $\begin{array}{c}2.5 \\
62 \\
3.6 \\
1.7 \\
1.3 \\
1.2\end{array}$ & $\begin{array}{l}0.87 \\
1.0 \\
1.1 \\
1.2 \\
1.2 \\
1.2\end{array}$ & $\begin{array}{l}1.7 \\
1.2 \\
1.3 \\
2.3 \\
1.2 \\
---\end{array}$ \\
\hline $\begin{array}{l}\text { TOTAL } \\
\text { MEAN } \\
\text { MAX } \\
\text { MIN } \\
\text { AC-FT }\end{array}$ & $\begin{array}{c}320.33 \\
10.3 \\
193 \\
0.81 \\
635\end{array}$ & $\begin{array}{c}169.4 \\
5.65 \\
72 \\
2.0 \\
336\end{array}$ & $\begin{array}{c}64.1 \\
2.07 \\
7.6 \\
1.5 \\
127\end{array}$ & $\begin{array}{c}65.4 \\
2.11 \\
6.1 \\
1.4 \\
130\end{array}$ & $\begin{array}{c}308.3 \\
10.6 \\
185 \\
1.1 \\
612\end{array}$ & $\begin{array}{c}205.9 \\
6.64 \\
144 \\
1.2 \\
408\end{array}$ & $\begin{array}{c}442.85 \\
14.8 \\
255 \\
0.86 \\
878\end{array}$ & $\begin{array}{c}45.48 \\
1.47 \\
4.4 \\
0.90 \\
90\end{array}$ & $\begin{array}{c}167.8 \\
5.59 \\
87 \\
1.0 \\
333\end{array}$ & $\begin{array}{c}674.6 \\
21.8 \\
261 \\
1.0 \\
1,340\end{array}$ & $\begin{array}{c}230.29 \\
7.43 \\
145 \\
0.87 \\
457\end{array}$ & $\begin{array}{c}176.94 \\
5.90 \\
122 \\
0.83 \\
351\end{array}$ \\
\hline
\end{tabular}

STATISTICS OF MONTHLY MEAN DATA FOR WATER YEARS 2000 - 2004, BY WATER YEAR (WY)

$\begin{array}{lcrrrrrrrrrrr}\text { MEAN } & 9.54 & 5.06 & 2.52 & 2.48 & 5.01 & 7.43 & 5.92 & 2.52 & 4.68 & 8.95 & 8.47 & 5.28 \\ \text { MAX } & 26.2 & 8.68 & 3.25 & 3.88 & 10.6 & 12.5 & 14.8 & 4.07 & 7.95 & 21.8 & 11.7 & 10.0 \\ \text { (WY) } & (2001) & (2001) & (2001) & (2001) & (2004) & (2000) & (2004) & (2001) & (2000) & (2004) & (2001) & (2002) \\ \text { MIN } & 2.25 & 2.94 & 1.92 & 0.92 & 0.93 & 0.75 & 1.83 & 1.06 & 2.36 & 1.25 & 3.26 & 2.79 \\ \text { (WY) } & (2002) & (2000) & (2003) & (2003) & (2002) & (2002) & (2000) & (2002) & (2003) & (2003) & (2003) & (2003)\end{array}$

\section{SUMMARY STATISTICS}

ANNUAL TOTAL

ANNUAL MEAN

HIGHEST ANNUAL MEAN

LOWEST ANNUAL MEAN

HIGHEST DAILY MEAN

LOWEST DAILY MEAN

MAXIMUM PEAK FLOW

MAXIMUM PEAK STAGE

ANNUAL RUNOFF (AC-FT)

10 PERCENT EXCEEDS

50 PERCENT EXCEEDS

90 PERCENT EXCEEDS

\section{FOR 2003 CALENDAR YEAR}

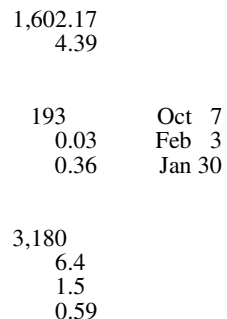

FOR 2004 WATER YEAR

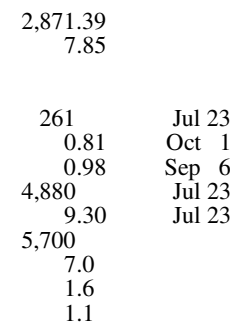

WATER YEARS 2000 - 2004

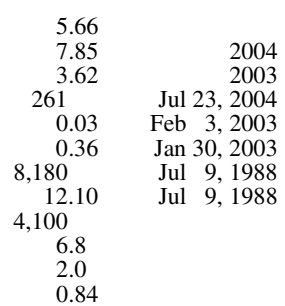

(+)Total precipitation accumulation, in inches.

e Estimated 


\section{HAHN ARROYO AT ALBUQUERQUE, NEW MEXICO}

\section{STATION ANALYSIS}

\section{WATER YEAR 2004}

Equipment.--An electronic datalogger, recording stage and precipitation on 5-minute intervals, and pressure transducer was installed on September 11, 1996. An ISCO automatic pump sampler was installed in the same shelter in October, 2001. All recorders are housed in a metal 4- by 4by 6-foot walk-in building anchored to a concrete pad on the right bank of the concrete-lined channel and all are solar powered. A roof-mounted, tipping-bucket rain gage has been operational since July 20, 1992. The reference gage is a staff gage painted on the channel sidewall near the orifice line. Water-depth measurements may be obtained near the orifice sump during low flows. A crest-stage gage with a lower cap elevation of 1.10 feet was installed on the right bank on October 8, 1998. The pipe is mounted 34 degrees from horizontal.

Gage-Height Record.-- The recorder, referenced to the outside staff gage or referenced to a direct measure-up from the bottom of the channel, gave a complete and satisfactory record for water year 2004 except for the following periods. Ice-affected gage heights occured on November 2225, 28-29, December 16-20, and 28-31, 2003, and on January 1-7, 9-11, 22-23, 26-29, February $1-5$, and 10-14, 2004. No precipition fell during these time periods except 0.04 inches on February 1. Estimated discharge values for this period of missing record only apply to base flows and were determined by averaging discharges recorded before and after the affected period. Two upstream gages, the North Fork and South Fork Hahn Arroyo (08329838 and 08329839), were discontinued in water year 2003, so they can no longer be used to estimate discharges at the Main Hahn gage. Storm-flows from the two upstream gages were previously combined and used as an approximation for this site. Since water year 1997, this station has been operated the entire year.

Rating.-- The control for this station is the concrete-lined channel. Rating 2.0 was developed by theoretical step-backwater computations after the gage was moved to its present location on July 20, 1992. After review of rating 2.0 in water year 1998, an error was discovered in the computations, resulting in a re-run of the step-backwater analysis and new rating 3.0. Water year records 1992-97 were revised using rating 3.0 and published in the water year 1999 USGS Annual Water-Data Report. In water year 2001, after further investigation of the theoretical rating analysis, a lower Manning's n-value of 0.015 was determined to be more accurate for the channel bottom roughness than the 0.018 used in the rating 3.0 analysis. The same survey points were used from ratings 2.0 and 3.0; only the Manning's n-value was changed in the theoretical computations. The resulting rating, 4.0, is retroactive to June 1992, requiring another slight revision to water years 1992-2000. Rating 4.0 computes approximately 10 percent more water than rating 3.0 for equivalent gage heights in the middle flow range.

Discharge.--Discharges were computed using the new rating 4.0 directly with no shifts. The curve is considered more reliable than any measurements. Significant flow in the channel is very swift and, therefore, nearly impossible to measure with conventional current meters. During water year 2004, 25 site visits were made. The instantaneous peak stage and discharge for the water year occurred on July 12, 2004, and were 2.33 feet and 676 cubic feet per second, respectively. Mean daily discharges were estimated for days mentioned in the "Gage Height Record" 
paragraph, when ice affected gage height readings.

Remarks.--Record is good, except estimated days which are poor. The Hahn Arroyo is a drainage canal, nearly always containing small flows which are not rainfall related ("nuisance flows"). Prior to rating 4.0, all days with discharges determined to be only nuisance flow (gage heights less than 1.04 feet and discharge less than 2.0 cubic feet per second), were called days of zero flow. Now all flows above zero flow are computed. Nearly every day of the year shows a pulse of water usually occurring in the early morning and late evening. probably due to lawn irrigation runoff. 
LOCATION.--Lat 3507'33", long 106³5'23", in SE 1/ ${ }_{4}$ NE 1/ ${ }_{4}$ sec.2, T.10 N., R.3 E., Bernalillo County, Hydrologic Unit 13020203 , 860 ft below San Mateo Boulevard bridge on right bank, $750 \mathrm{ft}$ north of Comanche Road, and 2,050 ft south of Montgomery Boulevard in Albuquerque.

DRAINAGE AREA.--4.23 $\mathrm{mi}^{2}$.

PERIOD OF RECORD.--June 1978 to September 1996 (seasonal records), October 1996 to current year.

REVISED RECORD.--WDR NM-99-1: 1992-98(M) (mean daily values).

GAGE.--Water-stage and recording tipping-bucket rain gage with 0.01-in. increment and concrete-lined channel. Elevation of gage is 5,190 ft above National Geodetic Vertical Datum of 1929, from topographic map. Prior to 1992, at site on downstream side of San Mateo Boulevard bridge, at different datum.

REMARKS.--Records good except for those estimated, which are poor. Some minor streamflow may exist on days when daily mean discharges have been recorded as zero due to the sensitivity limits of the streamflow-monitoring equipment. Recording rain gage at station. Development within basin is predominantly residential, but there are some commercial areas. See tabulation below for monthly precipitation, in inches.

DISCHARGE, CUBIC FEET PER SECOND

WATER YEAR OCTOBER 2003 TO SEPTEMBER 2004

\begin{tabular}{|c|c|c|c|c|c|c|c|c|c|c|c|c|}
\hline DAY & OCT & NOV & DEC & JAN & FEB & MAR & APR & MAY & JUN & JUL & AUG & SEP \\
\hline $\begin{array}{l}1 \\
2 \\
3 \\
4 \\
5\end{array}$ & $\begin{array}{l}1.2 \\
1.9 \\
3.1 \\
4.3 \\
2.5\end{array}$ & $\begin{array}{l}1.2 \\
0.72 \\
0.95 \\
0.51 \\
0.45\end{array}$ & $\begin{array}{l}2.2 \\
2.2 \\
1.4 \\
0.94 \\
0.80\end{array}$ & $\begin{array}{l}\text { e1.0 } \\
\text { e1.0 } \\
\text { e1.0 } \\
\text { e1.0 } \\
\text { e1.0 }\end{array}$ & $\begin{array}{l}\text { e } 1.5 \\
\text { e } 1.5 \\
\text { e1.5 } \\
\text { e } 1.5 \\
\text { e } 1.5\end{array}$ & $\begin{array}{c}1.8 \\
5.9 \\
4.0 \\
32 \\
9.4\end{array}$ & $\begin{array}{c}4.8 \\
12 \\
29 \\
10 \\
4.2\end{array}$ & $\begin{array}{l}1.4 \\
2.8 \\
3.4 \\
2.0 \\
1.7\end{array}$ & $\begin{array}{l}0.91 \\
1.3 \\
1.8 \\
1.2 \\
0.19\end{array}$ & $\begin{array}{l}2.0 \\
2.0 \\
0.57 \\
0.27 \\
1.2\end{array}$ & $\begin{array}{l}0.61 \\
5.5 \\
2.5 \\
9.7 \\
2.2\end{array}$ & $\begin{array}{l}2.0 \\
1.2 \\
1.3 \\
4.4 \\
0.85\end{array}$ \\
\hline $\begin{array}{r}6 \\
7 \\
8 \\
9 \\
10\end{array}$ & $\begin{array}{l}2.5 \\
20 \\
14 \\
1.9 \\
6.0\end{array}$ & $\begin{array}{l}0.59 \\
0.90 \\
0.80 \\
0.35 \\
0.75\end{array}$ & $\begin{array}{l}1.5 \\
0.94 \\
0.88 \\
1.2 \\
0.68\end{array}$ & $\begin{array}{r}\mathrm{e} 1.0 \\
\mathrm{e} 1.0 \\
1.1 \\
\mathrm{e} 1.0 \\
\mathrm{e} 1.0\end{array}$ & $\begin{array}{r}1.4 \\
1.0 \\
1.5 \\
1.1 \\
\mathrm{e} 1.5\end{array}$ & $\begin{array}{l}2.5 \\
1.4 \\
0.63 \\
1.5 \\
1.6\end{array}$ & $\begin{array}{c}2.6 \\
2.7 \\
13 \\
6.0 \\
9.9\end{array}$ & $\begin{array}{l}1.7 \\
1.5 \\
3.0 \\
0.31 \\
2.5\end{array}$ & $\begin{array}{l}0.29 \\
2.0 \\
1.7 \\
1.9 \\
2.2\end{array}$ & $\begin{array}{l}1.1 \\
0.65 \\
0.77 \\
1.3 \\
0.87\end{array}$ & $\begin{array}{l}1.5 \\
1.1 \\
0.45 \\
1.3 \\
5.7\end{array}$ & $\begin{array}{l}1.8 \\
1.4 \\
1.4 \\
1.3 \\
1.7\end{array}$ \\
\hline $\begin{array}{l}11 \\
12 \\
13 \\
14 \\
15\end{array}$ & $\begin{array}{l}4.2 \\
2.4 \\
1.7 \\
1.1 \\
1.3\end{array}$ & $\begin{array}{l}0.40 \\
18 \\
14 \\
2.2 \\
0.87\end{array}$ & $\begin{array}{l}1.2 \\
2.6 \\
1.2 \\
0.43 \\
0.42\end{array}$ & $\begin{array}{r}\text { e } 1.0 \\
1.1 \\
1.4 \\
1.2 \\
3.9\end{array}$ & $\begin{array}{r}\mathrm{e} 1.5 \\
\mathrm{e} 1.5 \\
\mathrm{e} 1.5 \\
\mathrm{e} 1.5 \\
1.6\end{array}$ & $\begin{array}{l}2.1 \\
2.0 \\
1.3 \\
1.4 \\
1.3\end{array}$ & $\begin{array}{l}2.1 \\
0.83 \\
1.3 \\
2.7 \\
2.4\end{array}$ & $\begin{array}{l}1.7 \\
1.7 \\
2.9 \\
1.6 \\
1.2\end{array}$ & $\begin{array}{l}1.9 \\
0.23 \\
0.37 \\
2.0 \\
1.8\end{array}$ & $\begin{array}{c}3.4 \\
16 \\
2.2 \\
4.0 \\
4.7\end{array}$ & $\begin{array}{l}1.6 \\
1.3 \\
1.1 \\
0.39 \\
0.20\end{array}$ & $\begin{array}{l}0.75 \\
0.83 \\
7.6 \\
2.4 \\
1.8\end{array}$ \\
\hline $\begin{array}{l}16 \\
17 \\
18 \\
19 \\
20\end{array}$ & $\begin{array}{l}0.69 \\
0.99 \\
0.36 \\
1.8 \\
1.3\end{array}$ & $\begin{array}{l}2.2 \\
1.1 \\
0.70 \\
1.1 \\
1.1\end{array}$ & $\begin{array}{l}\mathrm{e} 1.0 \\
\mathrm{e} 1.0 \\
\mathrm{e} 1.0 \\
\mathrm{e} 1.0 \\
\mathrm{e} 1.0\end{array}$ & $\begin{array}{l}3.6 \\
1.2 \\
0.91 \\
0.54 \\
3.5\end{array}$ & $\begin{array}{l}0.93 \\
1.5 \\
2.6 \\
1.9 \\
2.2\end{array}$ & $\begin{array}{l}2.0 \\
7.0 \\
6.2 \\
2.1 \\
1.0\end{array}$ & $\begin{array}{l}1.0 \\
0.37 \\
1.7 \\
1.1 \\
1.2\end{array}$ & $\begin{array}{l}2.3 \\
2.9 \\
1.6 \\
1.9 \\
1.9\end{array}$ & $\begin{array}{l}1.5 \\
2.1 \\
2.2 \\
0.72 \\
1.2\end{array}$ & $\begin{array}{l}3.0 \\
0.15 \\
0.31 \\
2.5 \\
6.5\end{array}$ & $\begin{array}{l}1.6 \\
0.92 \\
1.3 \\
2.5 \\
1.3\end{array}$ & $\begin{array}{c}2.2 \\
2.3 \\
2.3 \\
31 \\
8.4\end{array}$ \\
\hline $\begin{array}{l}21 \\
22 \\
23 \\
24 \\
25\end{array}$ & $\begin{array}{l}1.1 \\
1.2 \\
1.3 \\
1.9 \\
0.18\end{array}$ & $\begin{array}{r}1.5 \\
\text { e } 1.5 \\
\text { e1.5 } \\
\text { e } 1.5 \\
\text { e1.5 }\end{array}$ & $\begin{array}{l}1.3 \\
0.96 \\
1.2 \\
1.2 \\
1.3\end{array}$ & $\begin{array}{r}1.8 \\
\mathrm{e} 1.5 \\
\mathrm{e} 1.5 \\
1.8 \\
3.0\end{array}$ & $\begin{array}{c}5.9 \\
0.79 \\
24 \\
14 \\
3.0\end{array}$ & $\begin{array}{c}1.1 \\
2.7 \\
3.2 \\
10 \\
11\end{array}$ & $\begin{array}{l}0.83 \\
0.79 \\
0.99 \\
0.10 \\
0.85\end{array}$ & $\begin{array}{l}1.9 \\
1.3 \\
0.62 \\
1.1 \\
0.95\end{array}$ & $\begin{array}{l}3.5 \\
3.6 \\
2.5 \\
2.6 \\
3.1\end{array}$ & $\begin{array}{c}1.7 \\
2.7 \\
18 \\
5.4 \\
13\end{array}$ & $\begin{array}{l}1.7 \\
1.7 \\
1.9 \\
1.1 \\
1.3\end{array}$ & $\begin{array}{l}1.3 \\
1.4 \\
1.1 \\
1.6 \\
0.54\end{array}$ \\
\hline $\begin{array}{l}26 \\
27 \\
28 \\
29 \\
30 \\
31\end{array}$ & $\begin{array}{l}0.51 \\
0.57 \\
0.47 \\
2.1 \\
1.5 \\
1.6\end{array}$ & $\begin{array}{r}1.5 \\
1.7 \\
\mathrm{e} 1.5 \\
\mathrm{e} 1.5 \\
1.9 \\
---\end{array}$ & $\begin{array}{l}1.1 \\
0.64 \\
\mathrm{e} 1.0 \\
\mathrm{e} 1.0 \\
\mathrm{e} 1.0 \\
\mathrm{e} 1.0\end{array}$ & $\begin{array}{r}\mathrm{e} 1.5 \\
\mathrm{e} 1.5 \\
\mathrm{e} 1.5 \\
\mathrm{e} 1.5 \\
1.8 \\
1.3\end{array}$ & $\begin{array}{l}2.1 \\
3.6 \\
8.8 \\
0.64 \\
--- \\
---\end{array}$ & $\begin{array}{l}2.2 \\
0.78 \\
1.7 \\
3.8 \\
2.1 \\
2.2\end{array}$ & $\begin{array}{l}2.1 \\
1.6 \\
0.98 \\
1.8 \\
1.6 \\
---\end{array}$ & $\begin{array}{l}1.3 \\
1.2 \\
0.99 \\
0.13 \\
0.77 \\
2.0\end{array}$ & $\begin{array}{c}8.2 \\
0.84 \\
2.1 \\
14 \\
2.5 \\
---\end{array}$ & $\begin{array}{c}3.0 \\
18 \\
7.5 \\
1.6 \\
2.2 \\
0.39\end{array}$ & $\begin{array}{l}1.1 \\
1.4 \\
0.44 \\
0.74 \\
1.6 \\
1.2\end{array}$ & $\begin{array}{l}2.9 \\
2.6 \\
1.1 \\
1.9 \\
1.3 \\
---\end{array}$ \\
\hline $\begin{array}{l}\text { OTAL } \\
\text { IEAN } \\
\text { IAX } \\
\text { IIN } \\
\text { C-FT } \\
\end{array}$ & $\begin{array}{c}85.67 \\
2.76 \\
20 \\
0.18 \\
170 \\
1.32\end{array}$ & $\begin{array}{c}64.49 \\
2.15 \\
18 \\
0.35 \\
128 \\
0.87\end{array}$ & $\begin{array}{c}35.29 \\
1.14 \\
2.6 \\
0.42 \\
70 \\
0.14\end{array}$ & $\begin{array}{c}47.15 \\
1.52 \\
3.9 \\
0.54 \\
94 \\
0.14\end{array}$ & $\begin{array}{c}93.56 \\
3.23 \\
24 \\
0.64 \\
186 \\
1.47\end{array}$ & $\begin{array}{c}127.91 \\
4.13 \\
32 \\
0.63 \\
254 \\
0.87\end{array}$ & $\begin{array}{c}120.54 \\
4.02 \\
29 \\
0.10 \\
239 \\
1.86\end{array}$ & $\begin{array}{c}52.27 \\
1.69 \\
3.4 \\
0.13 \\
104 \\
0.00\end{array}$ & $\begin{array}{c}70.45 \\
2.35 \\
14 \\
0.19 \\
140 \\
0.66\end{array}$ & $\begin{array}{c}126.98 \\
4.10 \\
18 \\
0.15 \\
252 \\
3.13\end{array}$ & $\begin{array}{c}56.95 \\
1.84 \\
9.7 \\
0.20 \\
113 \\
0.94\end{array}$ & $\begin{array}{c}92.67 \\
3.09 \\
31 \\
0.54 \\
184 \\
1.18\end{array}$ \\
\hline
\end{tabular}

STATISTICS OF MONTHLY MEAN DATA FOR WATER YEARS 1997 - 2004, BY WATER YEAR (WY)

\begin{tabular}{|c|c|c|c|c|c|c|c|c|c|c|c|c|}
\hline MEAN & 2.25 & 1.46 & 1.30 & 1.51 & 1.78 & 2.62 & 2.08 & 1.33 & 2.38 & 3.07 & 3.21 & 1.9 \\
\hline MAX & 5.26 & 2.32 & 2.59 & 3.76 & 3.52 & 4.13 & 4.02 & 2.90 & 6.94 & 4.95 & 5.37 & 3. \\
\hline (WY) & (2001) & (2002) & (1998) & (2002) & (2001) & (2004) & (2004) & (2001) & (1999) & (1997) & (2001) & 200 \\
\hline MIN & 0.82 & 0.21 & 0.08 & 0.58 & 0.43 & 1.00 & 1.09 & 0.73 & 0.68 & 1.44 & 1.84 & 0. \\
\hline (WY) & (1998) & (2000) & (2000) & (2003) & (1997) & (1997) & (2003) & (1998) & (1998) & (2000) & (2004) & (199 \\
\hline
\end{tabular}

SUMMARY STATISTICS

ANNUAL TOTAL

ANNUAL MEAN

HIGHEST ANNUAL MEAN

LOWEST ANNUAL MEAN

HIGHEST DAILY MEAN

ANNUAL SEVEN-DAY MINIMUM

MAXIMUM PEAK FLOW

MAXIMUM PEAK STAGE

ANNUAL RUNOFF (AC-FT)

10 PERCENT EXCEEDS

50 PERCENT EXCEEDS

90 PERCENT EXCEEDS

(+) Total precipitation accumulation, in inches

e Estimated
FOR 2003 CALENDAR YEAR

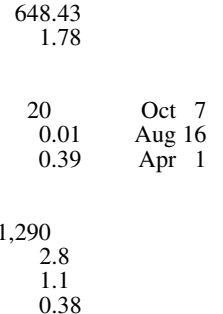

FOR 2004 WATER YEAR

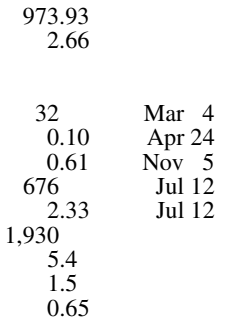

WATER YEARS 1997 - 2004

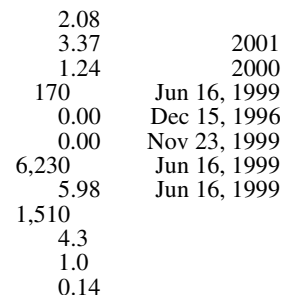




\section{BEAR CANYON ARROYO NEAR ALBUQUERQUE, NEW MEXICO}

\section{STATION ANALYSIS}

\section{WATER YEAR 2004}

Equipment.--An electronic datalogger, recording on 5-minute intervals, and a pressure transducer and self-contained air compressor, are housed in a metal 2.5- by 2.5 - by 6-foot shelter anchored to a concrete slab on the right bank of the channel. An outside staff gage is mounted on the right bank for reference. A crest-stage gage is mounted to the outside staff support and its bottom cap lip elevation is 3.90 feet referenced to the gage datum. A concrete control was constructed at the time of the gage installation on September 30, 1999. The point of zero flow (PZF) is the low point in this concrete control structure and is at an elevation of 3.47 feet. An ISCO model 3700 automatic sampler is housed in a separate metal shelter adjacent to the water-stage recorder enclosure. All instruments are powered by 12 -volt batteries charged by solar panels.

Gage-Height Record.-- The water-stage recorder, referenced to the PZF or outside staff, gave a complete and satisfactory record for the entire water year.

Rating.--This natural channel is straight for approximately 50 feet upstream and 100 feet downstream from the gage. The channel bottom is composed of coarse-grained sand and pea-sized gravel which has eroded from nearby granite exposures of the Sandia Mountains foothills. A narrow, $\mathrm{V}$-shaped main channel has incised approximately 6 to 8 feet into the terraced floodplain sediments. Large boulders are exposed in portions of both banks. The width of the main channel varies from approximately 6 feet immediately upstream from the gage to nearly 20 feet immediately downstream from the control. A mountain spring discharges into the stream nearly year-round, but the flow seeps into the unconsolidated, coarse-grained sediment before reaching the gage site.

Rating 1.0 was developed by a theoretical step-backwater analysis using HEC-RAS software model.

Discharge.-- During water year 2004, 15 no-flow inspections were made. No flows have occurred at this site since gage installation on September 30, 1999.

Remarks.-- Record is good. No flows occurred in water year 2004. 
RIO GRANDE BASIN

08329868 BEAR CANYON ARROYO NEAR ALBUQUERQUE, NM

LOCATION.--Lat $35^{\circ} 09^{\prime} 02^{\prime \prime}$, long $106^{\circ} 28^{\prime} 07^{\prime \prime}$, Bernalillo County, Hydrologic Unit 13020203 , in Elena Gallegos Grant, on right bank of the arroyo approximately $1 / 2 \mathrm{mi}$ east of gated and fenced property of High Resort Developement. Elena Galleogs open space land. The gage is approximately $1 /$ dirt access road which leads to an Albuquerque public water supply reservoir tank.

DRAINAGE AREA.--5.0 $\mathrm{mi}^{2}$.

PERIOD OF RECORD.--October 1999 to current year.

GAGE.--Water-stage recorder. Rain gage is located approximatley $1 / 2$ mi east. Elevation of gage is 6,395 $\mathrm{ft}$ above the National Vertical Datum of 1929 , from topographic map.

REMARKS.--Records good.

DISCHARGE, CUBIC FEET PER SECOND

WATER YEAR OCTOBER 2003 TO SEPTEMBER 2004

\begin{tabular}{|c|c|c|c|c|c|c|c|c|c|c|c|c|}
\hline DAY & OCT & NOV & DEC & JAN & FEB & MAR & APR & MAY & JUN & JUL & AUG & SEP \\
\hline $\begin{array}{l}1 \\
2 \\
3 \\
4 \\
5\end{array}$ & $\begin{array}{l}0.00 \\
0.00 \\
0.00 \\
0.00 \\
0.00\end{array}$ & $\begin{array}{l}0.00 \\
0.00 \\
0.00 \\
0.00 \\
0.00\end{array}$ & $\begin{array}{l}0.00 \\
0.00 \\
0.00 \\
0.00 \\
0.00\end{array}$ & $\begin{array}{l}0.00 \\
0.00 \\
0.00 \\
0.00 \\
0.00\end{array}$ & $\begin{array}{l}0.00 \\
0.00 \\
0.00 \\
0.00 \\
0.00\end{array}$ & $\begin{array}{l}0.00 \\
0.00 \\
0.00 \\
0.00 \\
0.00\end{array}$ & $\begin{array}{l}0.00 \\
0.00 \\
0.00 \\
0.00 \\
0.00\end{array}$ & $\begin{array}{l}0.00 \\
0.00 \\
0.00 \\
0.00 \\
0.00\end{array}$ & $\begin{array}{l}0.00 \\
0.00 \\
0.00 \\
0.00 \\
0.00\end{array}$ & $\begin{array}{l}0.00 \\
0.00 \\
0.00 \\
0.00 \\
0.00\end{array}$ & $\begin{array}{l}0.00 \\
0.00 \\
0.00 \\
0.00 \\
0.00\end{array}$ & $\begin{array}{l}0.00 \\
0.00 \\
0.00 \\
0.00 \\
0.00\end{array}$ \\
\hline $\begin{array}{r}6 \\
7 \\
8 \\
9 \\
10\end{array}$ & $\begin{array}{l}0.00 \\
0.00 \\
0.00 \\
0.00 \\
0.00\end{array}$ & $\begin{array}{l}0.00 \\
0.00 \\
0.00 \\
0.00 \\
0.00\end{array}$ & $\begin{array}{l}0.00 \\
0.00 \\
0.00 \\
0.00 \\
0.00\end{array}$ & $\begin{array}{l}0.00 \\
0.00 \\
0.00 \\
0.00 \\
0.00\end{array}$ & $\begin{array}{l}0.00 \\
0.00 \\
0.00 \\
0.00 \\
0.00\end{array}$ & $\begin{array}{l}0.00 \\
0.00 \\
0.00 \\
0.00 \\
0.00\end{array}$ & $\begin{array}{l}0.00 \\
0.00 \\
0.00 \\
0.00 \\
0.00\end{array}$ & $\begin{array}{l}0.00 \\
0.00 \\
0.00 \\
0.00 \\
0.00\end{array}$ & $\begin{array}{l}0.00 \\
0.00 \\
0.00 \\
0.00 \\
0.00\end{array}$ & $\begin{array}{l}0.00 \\
0.00 \\
0.00 \\
0.00 \\
0.00\end{array}$ & $\begin{array}{l}0.00 \\
0.00 \\
0.00 \\
0.00 \\
0.00\end{array}$ & $\begin{array}{l}0.00 \\
0.00 \\
0.00 \\
0.00 \\
0.00\end{array}$ \\
\hline $\begin{array}{l}11 \\
12 \\
13 \\
14 \\
15\end{array}$ & $\begin{array}{l}0.00 \\
0.00 \\
0.00 \\
0.00 \\
0.00\end{array}$ & $\begin{array}{l}0.00 \\
0.00 \\
0.00 \\
0.00 \\
0.00\end{array}$ & $\begin{array}{l}0.00 \\
0.00 \\
0.00 \\
0.00 \\
0.00\end{array}$ & $\begin{array}{l}0.00 \\
0.00 \\
0.00 \\
0.00 \\
0.00\end{array}$ & $\begin{array}{l}0.00 \\
0.00 \\
0.00 \\
0.00 \\
0.00\end{array}$ & $\begin{array}{l}0.00 \\
0.00 \\
0.00 \\
0.00 \\
0.00\end{array}$ & $\begin{array}{l}0.00 \\
0.00 \\
0.00 \\
0.00 \\
0.00\end{array}$ & $\begin{array}{l}0.00 \\
0.00 \\
0.00 \\
0.00 \\
0.00\end{array}$ & $\begin{array}{l}0.00 \\
0.00 \\
0.00 \\
0.00 \\
0.00\end{array}$ & $\begin{array}{l}0.00 \\
0.00 \\
0.00 \\
0.00 \\
0.00\end{array}$ & $\begin{array}{l}0.00 \\
0.00 \\
0.00 \\
0.00 \\
0.00\end{array}$ & $\begin{array}{l}0.00 \\
0.00 \\
0.00 \\
0.00 \\
0.00\end{array}$ \\
\hline $\begin{array}{l}16 \\
17 \\
18 \\
19 \\
20\end{array}$ & $\begin{array}{l}0.00 \\
0.00 \\
0.00 \\
0.00 \\
0.00\end{array}$ & $\begin{array}{l}0.00 \\
0.00 \\
0.00 \\
0.00 \\
0.00\end{array}$ & $\begin{array}{l}0.00 \\
0.00 \\
0.00 \\
0.00 \\
0.00\end{array}$ & $\begin{array}{l}0.00 \\
0.00 \\
0.00 \\
0.00 \\
0.00\end{array}$ & $\begin{array}{l}0.00 \\
0.00 \\
0.00 \\
0.00 \\
0.00\end{array}$ & $\begin{array}{l}0.00 \\
0.00 \\
0.00 \\
0.00 \\
0.00\end{array}$ & $\begin{array}{l}0.00 \\
0.00 \\
0.00 \\
0.00 \\
0.00\end{array}$ & $\begin{array}{l}0.00 \\
0.00 \\
0.00 \\
0.00 \\
0.00\end{array}$ & $\begin{array}{l}0.00 \\
0.00 \\
0.00 \\
0.00 \\
0.00\end{array}$ & $\begin{array}{l}0.00 \\
0.00 \\
0.00 \\
0.00 \\
0.00\end{array}$ & $\begin{array}{l}0.00 \\
0.00 \\
0.00 \\
0.00 \\
0.00\end{array}$ & $\begin{array}{l}0.00 \\
0.00 \\
0.00 \\
0.00 \\
0.00\end{array}$ \\
\hline $\begin{array}{l}21 \\
22 \\
23 \\
24 \\
25\end{array}$ & $\begin{array}{l}0.00 \\
0.00 \\
0.00 \\
0.00 \\
0.00\end{array}$ & $\begin{array}{l}0.00 \\
0.00 \\
0.00 \\
0.00 \\
0.00\end{array}$ & $\begin{array}{l}0.00 \\
0.00 \\
0.00 \\
0.00 \\
0.00\end{array}$ & $\begin{array}{l}0.00 \\
0.00 \\
0.00 \\
0.00 \\
0.00\end{array}$ & $\begin{array}{l}0.00 \\
0.00 \\
0.00 \\
0.00 \\
0.00\end{array}$ & $\begin{array}{l}0.00 \\
0.00 \\
0.00 \\
0.00 \\
0.00\end{array}$ & $\begin{array}{l}0.00 \\
0.00 \\
0.00 \\
0.00 \\
0.00\end{array}$ & $\begin{array}{l}0.00 \\
0.00 \\
0.00 \\
0.00 \\
0.00\end{array}$ & $\begin{array}{l}0.00 \\
0.00 \\
0.00 \\
0.00 \\
0.00\end{array}$ & $\begin{array}{l}0.00 \\
0.00 \\
0.00 \\
0.00 \\
0.00\end{array}$ & $\begin{array}{l}0.00 \\
0.00 \\
0.00 \\
0.00 \\
0.00\end{array}$ & $\begin{array}{l}0.00 \\
0.00 \\
0.00 \\
0.00 \\
0.00\end{array}$ \\
\hline $\begin{array}{l}26 \\
27 \\
28 \\
29 \\
30 \\
31\end{array}$ & $\begin{array}{l}0.00 \\
0.00 \\
0.00 \\
0.00 \\
0.00 \\
0.00\end{array}$ & $\begin{array}{c}0.00 \\
0.00 \\
0.00 \\
0.00 \\
0.00 \\
---\end{array}$ & $\begin{array}{l}0.00 \\
0.00 \\
0.00 \\
0.00 \\
0.00 \\
0.00\end{array}$ & $\begin{array}{l}0.00 \\
0.00 \\
0.00 \\
0.00 \\
0.00 \\
0.00\end{array}$ & $\begin{array}{c}0.00 \\
0.00 \\
0.00 \\
0.00 \\
--- \\
---\end{array}$ & $\begin{array}{l}0.00 \\
0.00 \\
0.00 \\
0.00 \\
0.00 \\
0.00\end{array}$ & $\begin{array}{l}0.00 \\
0.00 \\
0.00 \\
0.00 \\
0.00 \\
---\end{array}$ & $\begin{array}{l}0.00 \\
0.00 \\
0.00 \\
0.00 \\
0.00 \\
0.00\end{array}$ & $\begin{array}{l}0.00 \\
0.00 \\
0.00 \\
0.00 \\
0.00 \\
---\end{array}$ & $\begin{array}{l}0.00 \\
0.00 \\
0.00 \\
0.00 \\
0.00 \\
0.00\end{array}$ & $\begin{array}{l}0.00 \\
0.00 \\
0.00 \\
0.00 \\
0.00 \\
0.00\end{array}$ & $\begin{array}{l}0.00 \\
0.00 \\
0.00 \\
0.00 \\
0.00 \\
---\end{array}$ \\
\hline $\begin{array}{l}\text { TOTAL } \\
\text { MEAN } \\
\text { MAX } \\
\text { MIN } \\
\text { AC-FT }\end{array}$ & $\begin{array}{l}0.00 \\
0.00 \\
0.00 \\
0.00 \\
0.00\end{array}$ & $\begin{array}{l}0.00 \\
0.00 \\
0.00 \\
0.00 \\
0.00\end{array}$ & $\begin{array}{l}0.00 \\
0.00 \\
0.00 \\
0.00 \\
0.00\end{array}$ & $\begin{array}{l}0.00 \\
0.00 \\
0.00 \\
0.00 \\
0.00\end{array}$ & $\begin{array}{l}0.00 \\
0.00 \\
0.00 \\
0.00 \\
0.00\end{array}$ & $\begin{array}{l}0.00 \\
0.00 \\
0.00 \\
0.00 \\
0.00\end{array}$ & $\begin{array}{l}0.00 \\
0.00 \\
0.00 \\
0.00 \\
0.00\end{array}$ & $\begin{array}{l}0.00 \\
0.00 \\
0.00 \\
0.00 \\
0.00\end{array}$ & $\begin{array}{l}0.00 \\
0.00 \\
0.00 \\
0.00 \\
0.00\end{array}$ & $\begin{array}{l}0.00 \\
0.00 \\
0.00 \\
0.00 \\
0.00\end{array}$ & $\begin{array}{l}0.00 \\
0.00 \\
0.00 \\
0.00 \\
0.00\end{array}$ & $\begin{array}{l}0.00 \\
0.00 \\
0.00 \\
0.00 \\
0.00\end{array}$ \\
\hline \multicolumn{13}{|c|}{ STATISTICS OF MONTHLY MEAN DATA FOR WATER YEARS 2001 - 2004, BY WATER YEAR (WY) } \\
\hline $\begin{array}{l}\text { MEAN } \\
\text { MAX } \\
\text { (WY) } \\
\text { MIN } \\
\text { (WY) }\end{array}$ & $\begin{array}{r}0.00 \\
0.00 \\
(2001) \\
0.00 \\
(2001)\end{array}$ & $\begin{array}{r}0.00 \\
0.00 \\
(2001) \\
0.00 \\
(2001)\end{array}$ & $\begin{array}{r}0.00 \\
0.00 \\
(2001) \\
0.00 \\
(2001)\end{array}$ & $\begin{array}{r}0.00 \\
0.00 \\
(2001) \\
0.00 \\
(2001)\end{array}$ & $\begin{array}{r}0.00 \\
0.00 \\
(2001) \\
0.00 \\
(2001)\end{array}$ & $\begin{array}{r}0.00 \\
0.00 \\
(2001) \\
0.00 \\
(2001)\end{array}$ & $\begin{array}{r}0.00 \\
0.00 \\
(2001) \\
0.00 \\
(2001)\end{array}$ & $\begin{array}{r}0.00 \\
0.00 \\
(2001) \\
0.00 \\
(2001)\end{array}$ & $\begin{array}{r}0.00 \\
0.00 \\
(2001) \\
0.00 \\
(2001)\end{array}$ & $\begin{array}{r}0.00 \\
0.00 \\
(2001) \\
0.00 \\
(2001)\end{array}$ & $\begin{array}{r}0.00 \\
0.00 \\
(2001) \\
0.00 \\
(2001)\end{array}$ & $\begin{array}{r}0.00 \\
0.00 \\
(2001) \\
0.00 \\
(2001)\end{array}$ \\
\hline
\end{tabular}

SUMMARY STATISTICS

ANNUAL TOTAL

ANNUAL MEAN

HIGHEST ANNUAL MEAN

LOWEST ANNUAL MEAN

HIGHEST DAILY MEAN

LOWEST DAILY MEAN

ANNUAL SEVEN-DAY MINIMUM

MAXIMUM PEAK FLOW

ANNUAL RUNOFF (AC-FT)

10 PERCENT EXCEEDS

50 PERCENT EXCEEDS

90 PERCENT EXCEEDS
FOR 2003 CALENDAR YEAR

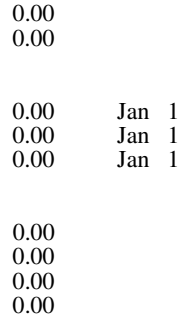

FOR 2004 WATER YEAR

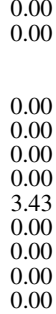

WATER YEARS 2001 - 2004

$\begin{array}{rrr}0.00 & & \\ 0.00 & & 2001 \\ 0.00 & & 2001 \\ 0.00 & \text { Oct } & 1,2000 \\ 0.00 & \text { Oct } & 1,2000 \\ 0.00 & \text { Oct } & 1,2000 \\ 0.00 & \text { Oct } & 1,1999 \\ 3.43 & \text { Oct } & 1,1999 \\ 0.00 & & \\ 0.00 & & \\ 0.00 & & \\ 0.00 & & \end{array}$




\section{STATION ANALYSIS}

\section{WATER YEAR 2004}

Equipment.-- The station was established on June 5, 2003. An electronic datalogger and pressure transducer, recording on 5-minute intervals, is housed in a 2.5- by 2.5- by 6 foot metal shelter anchored to a concrete pad. The gage is located on the right bank of the channel, immediately adjacent to a 30-foot wide concrete box culvert spillway drop-structure. A 1.5-foot high Ogeetype weir is the channel control at the downstream end of the 15-foot long box culvert. Two 1foot wide notches are cut into the weir face allowing better control for low flows. The upstream face of the weir is rounded and 4-foot high by 5-foot wide energy dissipator plates are mounted on the downstream spillway which drops approximately 20 feet to the next level of naturalbottom channel. The channel is also unlined upstream of the concrete box culvert drop structure. An outside staff gage is mounted on the right and left side-walls of the weir approach for reference. Both staffs are referenced to a Point of Zero Flow (PZF) at 0.00 foot elevation in the bottom of the right-side low-flow notch, approximately 12 feet below the orifice. A crest stage gage is mounted vertically to the right side of the concrete box culvert. The crest stage gage cap lip is at an elevation of 1.97 feet. The pressure transducer orifice is mounted 0.30 foot above the PZF so all flows less than 1.1 cubic feet per second, or a stage of 0.31 foot, will not be recorded.

Gage-Height Record.-- The stage recorder is referenced to the tape-up point of zero flow, which is the chiseled square in the bottom of the right-side low-flow notch, or is referenced to the outside staff gage during periods of significant flows. The recorder gave a complete and satisfactory record this water year, except for September 19 when the nitrogen tank was inadvertently shut off. The day's daily mean discharge was estimated based on an accurate peak gage height recorded by the crest-stage gage.

Rating.-- A theoretical rating was developed based on actual water-surface elevations observed for known unit discharges in a Bureau of Reclamation hydraulic flume. The baffled chute with an Ogee weir design, which was modeled in the flume, was the basis of the Bear Arroyo drop structure designed by ASCG, Incorporated engineering firm in Albuquerque. Results of the flume tests are published in the Bureau of Reclamation, Water Resources Technical Publication entitled "Design of Small Dams". The final rating was modified by the discharges computed by the HEC-RAS hydraulic modeling software through the 2 low-flow notches. The trapezoidalshaped, natural-bottom channel is straight for at least 1000 feet downstream and upstream of the gage. The rip-rapped banks are approximately 12 feet high and slope at approximately 20 degrees from horizontal. The channel bottom is about 40 feet wide. Flow measurements may be made near the gage for depths under 2 feet.

Discharge.--. Rating 1.0 was applied without shifts for the entire water year, since the control weir remained clear of debris. All flows below recorded gage heights of 0.31 feet (less than 1.1 cubic feet per second) are considered zero flow. A daily mean discharge was estimated only for September 19 as described in the "Gage Height Record" section above. No gage exists upstream for hydrographic comparisons, so only precipitation records within the drainage basin can be used for estimating discharges, and occasionally a high water mark or crest stage gage mark will indicate the peak stage. 
During water year 2004, 31 inspections were made. The maximum gage height and discharge for water year 2004 was 4.66 feet and 567 cubic feet per second respectively, on July 12. This was also a new peak for the period of record. 
RIO GRANDE BASIN

08329870 BEAR ARROYO AT JEFFERSON STREET AT ALBUQUERQUE, NM

LOCATION.--Lat 3509'03", long 106 35'52", Bernalillo County, Hydrologic Unit 13020203, in Elena Gallegos Grant, on the right bank, 1,320 ft downstream from the Jefferson Street bridge over Bear Arroyo, approximately / ${ }_{4}$ mi south of the intersection of Jefferson Street with Osuna Road in the northeast quadrant of Albuquerque.

DRAINAGE AREA.--Controlled by detention pond upstream.

PERIOD OF RECORD.--June 2003 to current year.

GAGE.--Water-stage recorder, crest-stage gage, and concrete control weir. Elevation of gage is 5,130 ft above National Geodetic Vertical Datum of 1929 , from topographic map.

REMARKS.--Records good except for those estimated, which are poor.

EXTREMES FOR PERIOD OF RECORD.--Maximum discharge, $567 \mathrm{ft}^{3} / \mathrm{s}$, July 12, 2004, gage height, $4.66 \mathrm{ft}$, from standard design rating of concrete weir. No flow most of time.

EXTREMES FOR CURRENT YEAR.--Maximum discharge during period of seasonal operation, $567 \mathrm{ft}^{3} / \mathrm{s}$, July 12 , gage height, $4.66 \mathrm{ft}$. No flow most of time.

DISCHARGE, CUBIC FEET PER SECOND

WATER YEAR OCTOBER 2003 TO SEPTEMBER 2004

\begin{tabular}{|c|c|c|c|c|c|c|c|c|c|c|c|c|}
\hline DAY & OCT & NOV & DEC & JAN & FEB & MAR & APR & MAY & JUN & JUL & AUG & SEP \\
\hline 1 & 0.00 & 0.00 & 0.00 & 0.00 & 0.00 & 0.00 & 0.00 & 0.00 & 0.00 & 0.00 & 0.00 & 0.00 \\
\hline 2 & 0.00 & 0.00 & 0.00 & 0.00 & 0.00 & 0.00 & 0.04 & 0.00 & 0.00 & 0.00 & 0.00 & 0.00 \\
\hline 3 & 0.00 & 0.00 & 0.00 & 0.00 & 0.00 & 0.00 & 17 & 0.00 & 0.00 & 0.00 & 0.00 & 0.00 \\
\hline 4 & 0.00 & 0.00 & 0.00 & 0.00 & 0.00 & 13 & 2.6 & 0.00 & 0.00 & 0.00 & 5.0 & 0.00 \\
\hline 5 & 0.00 & 0.00 & 0.00 & 0.00 & 0.00 & 0.56 & 0.00 & 0.00 & 0.00 & 0.00 & 0.28 & 0.00 \\
\hline 6 & 0.00 & 0.00 & 0.00 & 0.00 & 0.00 & 0.00 & 0.00 & 0.00 & 0.00 & 0.00 & 0.00 & 0.00 \\
\hline 7 & 8.2 & 0.00 & 0.00 & 0.00 & 0.00 & 0.00 & 0.00 & 0.00 & 0.00 & 0.00 & 0.00 & 0.00 \\
\hline 8 & 1.4 & 0.00 & 0.00 & 0.00 & 0.00 & 0.00 & 4.2 & 0.00 & 0.00 & 0.00 & 0.00 & 0.00 \\
\hline 9 & 0.00 & 0.00 & 0.00 & 0.00 & 0.00 & 0.00 & 1.4 & 0.00 & 0.00 & 0.00 & 0.00 & 0.00 \\
\hline 10 & 0.00 & 0.00 & 0.00 & 0.00 & 0.00 & 0.00 & 3.2 & 0.00 & 0.00 & 0.00 & 0.00 & 0.00 \\
\hline 11 & 0.28 & 0.00 & 0.00 & 0.00 & 0.00 & 0.00 & 0.00 & 0.00 & 0.00 & 0.35 & 0.00 & 0.00 \\
\hline 12 & 0.00 & 2.3 & 0.00 & 0.00 & 0.00 & 0.00 & 0.00 & 0.00 & 0.00 & 15 & 0.00 & 0.00 \\
\hline 13 & 0.00 & 2.3 & 0.00 & 0.00 & 0.00 & 0.00 & 0.00 & 0.00 & 0.00 & 0.00 & 0.00 & 0.00 \\
\hline 14 & 0.00 & 0.00 & 0.00 & 0.00 & 0.00 & 0.00 & 0.00 & 0.00 & 0.00 & 0.00 & 0.00 & 0.00 \\
\hline 15 & 0.00 & 0.00 & 0.00 & 0.00 & 0.00 & 0.00 & 0.00 & 0.00 & 0.00 & 0.00 & 0.00 & 0.00 \\
\hline 16 & 0.00 & 0.00 & 0.00 & 0.00 & 0.00 & 0.00 & 0.00 & 0.00 & 0.00 & 0.00 & 0.00 & 0.00 \\
\hline 17 & 0.00 & 0.00 & 0.00 & 0.00 & 0.00 & 0.00 & 0.00 & 0.00 & 0.00 & 0.00 & 0.00 & 0.04 \\
\hline 18 & 0.00 & 0.00 & 0.00 & 0.00 & 0.00 & 0.00 & 0.00 & 0.00 & 0.00 & 0.00 & 0.00 & 0.00 \\
\hline 19 & 0.00 & 0.00 & 0.00 & 0.00 & 0.00 & 0.00 & 0.00 & 0.00 & 0.00 & 0.00 & 0.00 & e11 \\
\hline 20 & 0.00 & 0.00 & 0.00 & 0.00 & 0.00 & 0.00 & 0.00 & 0.00 & 0.00 & 0.00 & 0.00 & 0.00 \\
\hline 21 & 0.00 & 0.00 & 0.00 & 0.00 & 0.00 & 0.00 & 0.00 & 0.00 & 0.00 & 0.00 & 0.00 & 0.00 \\
\hline 22 & 0.00 & 0.00 & 0.00 & 0.00 & 0.00 & 0.00 & 0.00 & 0.00 & 0.00 & 0.84 & 0.00 & 0.00 \\
\hline 23 & 0.00 & 0.00 & 0.00 & 0.00 & 9.6 & 0.00 & 0.00 & 0.00 & 0.00 & 12 & 0.00 & 0.00 \\
\hline 24 & 0.00 & 0.00 & 0.00 & 0.00 & 3.0 & 0.00 & 0.00 & 0.00 & 0.00 & 0.05 & 0.00 & 0.00 \\
\hline 25 & 0.00 & 0.00 & 0.00 & 0.00 & 0.00 & 0.00 & 0.00 & 0.00 & 0.00 & 4.4 & 0.00 & 0.00 \\
\hline 26 & 0.00 & 0.00 & 0.00 & 0.00 & 0.00 & 0.00 & 0.00 & 0.00 & 0.00 & 0.00 & 0.00 & 0.00 \\
\hline 27 & 0.00 & 0.00 & 0.00 & 0.00 & 0.00 & 0.00 & 0.00 & 0.00 & 0.00 & 11 & 0.00 & 0.00 \\
\hline 28 & 0.00 & 0.00 & 0.00 & 0.00 & 0.16 & 0.00 & 0.00 & 0.00 & 0.00 & 0.23 & 0.00 & 0.00 \\
\hline 29 & 0.00 & 0.00 & 0.00 & 0.00 & 0.00 & 0.00 & 0.00 & 0.00 & 2.0 & 0.00 & 0.00 & 0.37 \\
\hline 30 & 0.00 & 0.00 & 0.00 & 0.00 & --- & 0.00 & 0.00 & 0.00 & 0.00 & 0.00 & 0.00 & 0.00 \\
\hline 31 & 0.00 & --- & 0.00 & 0.00 & --- & 0.00 & --- & 0.00 & --- & 0.00 & 0.00 & --- \\
\hline OTAL & 9.88 & 4.60 & 0.00 & 0.00 & 12.76 & 13.56 & 28.44 & 0.00 & 2.00 & 43.87 & 5.28 & 11.41 \\
\hline IEAN & 0.32 & 0.15 & 0.00 & 0.00 & 0.44 & 0.44 & 0.95 & 0.00 & 0.07 & 1.42 & 0.17 & 0.38 \\
\hline IAX & 8.2 & 2.3 & 0.00 & 0.00 & 9.6 & 13 & 17 & 0.00 & 2.0 & 15 & 5.0 & 11 \\
\hline IIN & 0.00 & 0.00 & 0.00 & 0.00 & 0.00 & 0.00 & 0.00 & 0.00 & 0.00 & 0.00 & 0.00 & 0.00 \\
\hline C-FT & 20 & 9.1 & 0.00 & 0.00 & 25 & 27 & 56 & 0.00 & 4.0 & 87 & 10 & 23 \\
\hline
\end{tabular}

STATISTICS OF MONTHLY MEAN DATA FOR WATER YEARS 2003 - 2004, BY WATER YEAR (WY)

\begin{tabular}{|c|c|c|c|c|c|c|c|c|c|c|c|c|}
\hline MEAN & 0.32 & 0.15 & 0.00 & 0.00 & 0.44 & 0.44 & 0.95 & 0.00 & 0.07 & 0.71 & 0.15 & 0.19 \\
\hline MAX & 0.32 & 0.15 & 0.00 & 0.00 & 0.44 & 0.44 & 0.95 & 0.00 & 0.07 & 1.42 & 0.17 & 0.38 \\
\hline (WY) & (2004) & (2004) & (2004) & (2004) & (2004) & (2004) & (2004) & (2004) & (2004) & (2004) & (2004) & (2004) \\
\hline MIN & 0.32 & 0.15 & 0.00 & 0.00 & 0.44 & 0.44 & 0.95 & 0.00 & 0.07 & 0.00 & 0.12 & 0.01 \\
\hline (WY) & (2004) & (2004) & (2004) & (2004) & (2004) & (2004) & (2004) & (2004) & (2004) & (2003) & (2003) & (2003) \\
\hline
\end{tabular}

SUMMARY STATISTICS

FOR 2004 WATER YEAR

ANNUAL TOTAL

ANNUAL MEAN

HIGHEST ANNUAL MEAN

LOWEST ANNUAL MEAN

HIGHEST DAILY MEAN

LOWEST DAILY MEAN

MAXIMUM PEAK FLOW

MAXIMUM PEAK STAGE

ANNUAL RUNOFF (AC-FT)

10 PERCENT EXCEEDS

50 PERCENT EXCEEDS

90 PERCENT EXCEEDS

e Estimated

$\begin{array}{cc}131.80 & \\ 0.36 & \\ & \\ 17 & \text { Apr 3 } \\ 0.00 & \text { Oct 1 } \\ 0.00 & \text { Oct 12 } \\ 567 & \text { Jul 12 } \\ 4.66 & \text { Jul 12 } \\ 261 & \\ 0.00 & \\ 0.00 & \\ 0.00 & \end{array}$

WATER YEARS 2003 - 2004

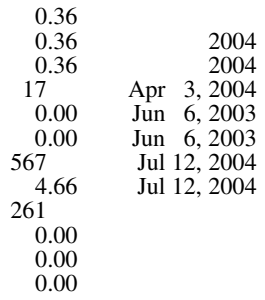




\section{PINO ARROYO AT JEFFERSON ST. AT ALBUQUERQUE, NEW MEXICO}

\section{STATION ANALYSIS}

\section{WATER YEAR 2004}

Equipment.-- The station was established on May 18, 2000. An electronic datalogger and pressure transducer, recording on 5-minute intervals, is housed in a 2.5 - by 2.5 - by 6 -foot metal shelter anchored to a concrete pad on the right bank of the concrete-lined channel. An outside staff gage is painted on the right and left side-walls of the channel for reference. A reference point for water depth tape-ups was also established as a 9/16-inch hex-head lag bolt anchored in the channel bottom about 12 inches from the orifice. This bolt represents the point of zero flow $(\mathrm{PZF})$. A crest-stage gage is mounted to the side of the channel and is inclined 24.5 degrees from horizontal. The high point of the lower crest-stage gage cap lip is at an elevation of 2.10 feet (1.10 feet true depth with a 1.00foot datum added to recorded gage heights to avoid negative values). On August 22, 2001, a large static tube was installed around the end of the pressure transducer line to slow down flow velocities passing over the orifice. Prior to this, the recorded gage heights during larger flows were much lower than true depths, reflecting the pressure draw-down that was occurring around the old orifice tube. In October, 2001, an ISCO automatic pump sampler was installed in a 36-inch diameter shelter 3 feet upstream from the stream-flow gage and is powered by a solar-panel charged deep-cycle marine battery.

Gage-Height Record.-- The stage recorder is referenced to the tape-up PZF, which is the lag bolt anchored in the bottom of the channel, or is referenced to the outside staff gage during periods of significant flows. The recorder will normally read 1.00 foot when the water level is even with the bottom of the channel at PZF; however, the installation of the static tube on August 22, 2001 raised the orifice line 0.03 feet above the PZF. Therefore, only flows over 0.03 foot deep ( 1.03 on recorder) will be recorded. The recorder gave a complete and satisfactory record this water year, except for the following periods. Gageheight readings were affected by sediment accumulation in the orifice sump on October 4-6, 2003. Gage-height readings were affected by ice on November 24, 26, 29, and December 3 and 4, 2003. October 4-6 were estimated by comparing base flows before and after the affected period, and by looking at rainfall in the watershed. All ice-affected daily mean discharges were estimated as zero in water year 2004. The gage was shut down for the winter period December 3, 2003 to March 2, 2004.

Rating.-- The steeply sloping channel (0.022 foot per foot) acts as the control. A theoretical rating was developed using the USGS software "Water Surface Profile" (WSPRO). Since flows are supercritical in this reach, a step-forward analysis was used. The trapezoidalshaped channel is straight for at least 300 feet downstream and 1,200 feet upstream from the gage. Side walls are approximately 6.5 feet high and slope at 24.5 degrees from horizontal. The channel bottom is about 8 feet wide. This site will be nearly impossible to measure because of its flashy nature and extreme velocities.

During water year 2004, 20 inspections were made. Rating 2.0 was developed in water 
year 2001 and is the same as rating 1.0, except that all flows below recorded gage heights of 1.04 feet (less than $0.90 \mathrm{cfs}$.) are considered zero flow. This change was required because flows below 0.04 feet deep could not be detected after the static tube was installed on August 22, 2001.

No sediment or debris accumulates in the channel due to its high flow velocity, so no shifts to the rating are needed.

Discharge.--. The extreme flow velocities at this site make the theoretical rating more reliable than any measurements. Wading measurements would be dangerous, even at shallow depths. Rating 2.0 was used directly for water year 2004 with no shifts applied.

Daily mean discharges were estimated for October 4-6 and the ice-affected days as described in the "Gage Height Record" section above. No gage exists upstream for hydrographic comparisons, so only precipitation records within the drainage basin can be used for estimating discharges, and occasionally a high-water mark or crest-stage gage mark indicates the peak stage.

The maximum gage height and discharge for the water year 2004 were 3.55 feet and 728 cubic feet per second respectively, on July 12. This was also a new peak for the period of record. 
RIO GRANDE BASIN

08329882 PINO ARROYO AT JEFFERSON STREET AT ALBUQUERQUE, NM

LOCATION.--Lat 3509'34", long 106 $35^{\prime} 51^{\prime \prime}$, Bernalillo County, Hydrologic Unit 13020203, in the Elena Gallegos Grant, on the right bank 1,200 ft downstream from the Jefferson Street culvert over Pino Arroyo, approximately 1,200 ft north of the intersection of Jefferson St. and Osuna Road in northeast Albuquerque.

DRAINAGE AREA.--8.3 $\mathrm{mi}^{2}$ (but is controlled by detention pond upstream).

PERIOD OF RECORD.--May 18, 2000, to Dec. 4, 2003, March 2004 to current year (seasonal records).

GAGE.--Water-stage recorder, crest-stage gage, and concrete-lined channel. Elevation of gage is 5,119 ft above National Geodetic Vertical Datum of 1929 , from topographic map.

REMARKS.--Water-stage records good except for those estimated, which are fair. Since installation of the large static tube around the orifice on Aug. 22, 2001, only flows more than about $0.03 \mathrm{ft}$ deep (1.03 on recorder) will cover the orifice sufficiently to record true water depths. This channel often shows trickle flows not related to rainfall.

EXTREMES FOR PERIOD OF RECORD.--Maximum discharge, $728 \mathrm{ft}^{3} / \mathrm{s}$, July 12, 2004, gage height, $3.55 \mathrm{ft}$.

EXTREMES FOR CURRENT YEAR.--Maximum discharge during period of seasonal operation, $728 \mathrm{ft}^{3} / \mathrm{s}$, July 12 , gage height, $3.55 \mathrm{ft}$.

DISCHARGE CUBIC FEET PER SECOND

WATER YEAR OCTOBER 2003 TO SEPTEMBER 2004

\begin{tabular}{|c|c|c|c|c|c|c|c|c|c|c|c|c|}
\hline DAY & OCT & NOV & DEC & JAN & FEB & MAR & APR & MAY & JUN & JUL & AUG & SEP \\
\hline 1 & 0.25 & 0.44 & 0.00 & --- & --- & --- & 0.00 & 0.00 & 0.00 & 0.00 & 0.00 & 0.00 \\
\hline 2 & 0.72 & 0.36 & 0.00 & --- & --- & e 1.5 & 1.7 & 0.00 & 0.00 & 0.00 & 0.78 & 0.00 \\
\hline 3 & 0.82 & 0.26 & $\mathrm{e} 0.00$ & --- & --- & 0.11 & 12 & 0.00 & 0.00 & 0.00 & 0.08 & 0.00 \\
\hline 4 & e1.0 & 0.09 & $\mathrm{e} 0.00$ & --- & --- & 9.2 & 0.83 & 0.00 & 0.00 & 0.00 & 0.71 & 0.22 \\
\hline 5 & $\mathrm{e} 0.50$ & 0.00 & --- & --- & --- & 0.37 & 0.00 & 0.00 & 0.01 & 0.00 & 0.09 & 0.02 \\
\hline 6 & $\mathrm{e} 0.50$ & 0.00 & --- & --- & --- & 0.00 & 0.00 & 0.00 & 0.00 & 0.00 & 0.00 & 0.00 \\
\hline 7 & 6.0 & 0.00 & --- & --- & --- & 0.00 & 0.00 & 0.00 & 0.00 & 0.00 & 0.00 & 0.00 \\
\hline 8 & 3.1 & 0.00 & --- & --- & --- & 0.00 & 2.1 & 0.00 & 0.00 & 0.00 & 0.00 & 0.00 \\
\hline 9 & 0.22 & 0.00 & --- & --- & --- & 0.00 & 1.2 & 0.00 & 0.00 & 0.00 & 0.00 & 0.00 \\
\hline 10 & 0.44 & 0.00 & --- & --- & --- & 0.02 & 2.2 & 0.00 & 0.00 & 0.00 & 0.08 & 0.00 \\
\hline 11 & 0.23 & 0.00 & --- & --- & --- & 0.01 & 0.04 & 0.00 & 0.00 & 2.4 & 0.00 & 0.00 \\
\hline 12 & 0.00 & 4.1 & --- & --- & --- & 0.00 & 0.00 & 0.00 & 0.00 & 18 & 0.00 & 0.00 \\
\hline 13 & 0.00 & 3.4 & --- & --- & --- & 0.00 & 0.00 & 0.00 & 0.00 & 0.71 & 0.00 & 0.00 \\
\hline 14 & 0.00 & 0.11 & --- & --- & --- & 0.00 & 0.00 & 0.00 & 0.00 & 0.07 & 0.00 & 0.00 \\
\hline 15 & 0.00 & 0.00 & --- & --- & --- & 0.00 & 0.00 & 0.00 & 0.00 & 0.04 & 0.00 & 0.00 \\
\hline 16 & 0.00 & 0.05 & --- & --- & --- & 0.00 & 0.00 & 0.00 & 0.00 & 0.00 & 0.00 & 0.00 \\
\hline 17 & 0.01 & 0.09 & --- & --- & --- & 0.00 & 0.00 & 0.00 & 0.00 & 0.00 & 0.00 & 0.00 \\
\hline 18 & 0.00 & 0.09 & --- & --- & --- & 0.00 & 0.00 & 0.00 & 0.00 & 0.15 & 0.03 & 0.08 \\
\hline 19 & 0.03 & 0.00 & --- & --- & --- & 0.00 & 0.00 & 0.00 & 0.00 & 0.01 & 0.35 & 8.4 \\
\hline 20 & 0.23 & 0.00 & --- & --- & --- & 0.00 & 0.00 & 0.00 & 0.00 & 0.89 & 0.00 & 0.60 \\
\hline 21 & 0.77 & 0.00 & --- & --- & --- & 0.00 & 0.00 & 0.00 & 0.00 & 0.15 & 0.00 & 0.00 \\
\hline 22 & 1.2 & 0.00 & --- & --- & --- & 0.00 & 0.00 & 0.00 & 0.00 & 0.82 & 0.00 & 0.00 \\
\hline 23 & 1.2 & 0.00 & --- & --- & --- & 0.20 & 0.00 & 0.00 & 0.02 & 16 & 0.00 & 0.00 \\
\hline 24 & 1.2 & $\mathrm{e} 0.00$ & --- & --- & --- & 0.02 & 0.00 & 0.00 & 0.00 & 1.3 & 0.00 & 0.00 \\
\hline 25 & 1.1 & 0.00 & --- & --- & --- & 0.00 & 0.00 & 0.00 & 0.00 & 2.5 & 0.00 & 0.00 \\
\hline 26 & 1.1 & $\mathrm{e} 0.00$ & --- & --- & --- & 0.00 & 0.00 & 0.01 & 0.70 & 0.03 & 0.00 & 0.00 \\
\hline 27 & 1.4 & 0.00 & --- & --- & --- & 0.00 & 0.00 & 0.00 & 0.00 & 7.2 & 0.00 & 0.00 \\
\hline 28 & 1.3 & 0.00 & --- & --- & --- & 0.00 & 0.00 & 0.00 & 0.00 & 0.75 & 0.00 & 0.00 \\
\hline 29 & 0.81 & $\mathrm{e} 0.00$ & --- & --- & --- & 0.00 & 0.00 & 0.00 & 5.2 & 0.00 & 0.00 & 3.3 \\
\hline 30 & 0.75 & 0.00 & --- & --- & --- & 0.00 & 0.00 & 0.00 & 0.03 & 0.00 & 0.00 & 0.00 \\
\hline 31 & 0.44 & --- & --- & --- & --- & 0.00 & --- & 0.00 & --- & 0.00 & 0.00 & --- \\
\hline TOTAL & 25.32 & 8.99 & --- & --- & --- & --- & 20.07 & 0.01 & 5.96 & 51.02 & 2.12 & 12.62 \\
\hline MEAN & 0.82 & 0.30 & --- & --- & --- & --- & 0.67 & 0.00 & 0.20 & 1.65 & 0.07 & 0.42 \\
\hline MAX & 6.0 & 4.1 & --- & --- & --- & --- & 12 & 0.01 & 5.2 & 18 & 0.78 & 8.4 \\
\hline MIN & 0.00 & 0.00 & --- & --- & --- & --- & 0.00 & 0.00 & 0.00 & 0.00 & 0.00 & 0.00 \\
\hline AC-FT & 50 & 18 & --- & --- & --- & --- & 40 & 0.02 & 12 & 101 & 4.2 & 25 \\
\hline
\end{tabular}

e Estimated 


\section{LA CUEVA ARROYO TRIBUTARY (UPPER) AT ALBUQUERQUE, NEW MEXICO}

\section{STATION ANALYSIS}

\section{WATER YEAR 2004}

Equipment.-- An electronic datalogger, recording on 5-minute intervals, and pressure transducer are housed in a 2.5 - by 2.5 - by 5.5 -foot metal shelter anchored to a concrete slab on the left bank of the channel, approximately 100 feet upstream of a concrete box culvert under Tramway Boulevard. An outside staff gage is mounted on the right and left bank for reference. High-water discharge measurements are computed by indirect methods. A crest-stage gage was installed on May 6, 1999 and its bottom cap lip elevation is 0.36 foot above the Point of Zero Flow (PZF). It is mounted to the left bank staff gage.

Gage-Height Record.-- The water-stage recorder, referenced to the PZF or outside staff, gave a complete and satisfactory record for the entire water year. Since this channel will not flow without significant precipitation, any days of missing record and no precipitation can be accurately interpreted as zero-flow days. A 1.00-foot datum is added to the recorded gage heights to avoid negative values during dry periods. The gage was shut down during the winter period December 2, 2003 to March 3, 2004.

Rating.-- The trapezoidal-shaped channel is straight for about 100 feet above and 100 feet below the gage before it drops sharply into a concrete box culvert which passes under Tramway Boulevard. This channel has a natural, course-grained sand bottom and concrete sidewalls. The concrete sidewalls extend from approximately 6 feet upstream of the gage to the box culvert downstream. Upstream from the concrete-lined channel, the side slopes are covered with cobble and boulder rip-rap. The channel bottom is about 12 feet wide at the gage, slightly narrower upstream, and has sidewalls about 4 feet high with 30 degree slopes. A concrete control structure was installed immediately downstream from the gage on May 6, 1999. The concrete slab is inclined from the right channel sidewall towards the left bank, where the gage is located. The PZF of the gage is located at the juncture of the concrete control with the left sidewall. Prior to the installation of this control, only high flows could reach the pressure transducer orifice because the channel bottom had severely scoured. The orifice was mounted approximately 0.08 foot above the PZF so sediment will not interfere with gage height recordings; therefore, only flow depths greater than 0.08 foot are recorded. Most flows are supercritical regime because of the steep channel slope.

Rating 1.0, used since the concrete control installation on May 6, 1999, was developed by step-forward analysis using the USGS WSPRO (Water Surface Profile) software. Watersurface elevations for flows less than 30 cubic feet per second could not be successfully computed because the energy equation for supercritical flow would not balance at the gage cross-section. These smaller flows are probably experiencing subcritical regimes. Additional measurements are needed to better define the rating, especially at the lower end. Two very low-flow measurements (\#1 and \#2) were made in water year 1999, but no measurements have been made since. Flow events are extremely flashy, normally existing less than an hour, so discharge measurements are difficult to obtain. The two measurements plot at 0.0 and - 46 percent from rating 1.0, respectively. Because both were made during extremely low flow, they are rated "poor" and serve only as a good estimate of discharge. High-water discharge measurements are computed by indirect methods. 
The PZF is 1.00 foot on rating 1.0. A "dog leg" break to the left occurs at a gage height of 1.70 feet on the rating curve. This point represents the level when the concrete control is completely submerged and flows begin to be constricted by both concrete sidewalls.

Discharge.-- During the water year 2004, 13 no-flow inspections were completed. Rating 1.0 was used directly, without any shifts, for the water year. The maximum instantaneous stage and discharge recorded during the water year are 1.45 feet and 6.1 cubic feet per second, respectively, on August 14. This site will remain dry except during significant precipitation. 
LOCATION.--Lat $35^{\circ} 11^{\prime} 22^{\prime \prime}$, long 106 $29^{\prime} 43^{\prime \prime}$, Bernalillo County, Hydrologic Unit 13020203, in Elena Gallegos Grant, on the left bank of concrete-lined arroyo, approximately $100 \mathrm{ft}$ upstream from a box culvert passing under Tramway Blvd., in the extreme northeast corner of Albuquerque city limits. This site is located approximately $0.2 \mathrm{mi}$ south of the old gage site La Cueva Arroyo Tributary at Tramway Blvd. (08329890).

DRAINAGE AREA.--0.5103 $\mathrm{mi}^{2}$.

PERIOD OF RECORD.--May 1999 to current year (seasonal records).

GAGE.--Water-stage recorder. A tipping-bucket rain gage recording in 0.01-inch increments is located approximately 0.25 mi north of gage. Elevation of gage is $6,080 \mathrm{ft}$ above National Geodetic Vertical Datum of 1929, from topographic map.

REMARKS.--Records good.

EXTREMES FOR PERIOD OF RECORD.--Maximum discharge, $12 \mathrm{ft}^{3} / \mathrm{s}$, Aug. 14, 2001, gage height, $1.56 \mathrm{ft}$. No flow most of time.

EXTREMES FOR CURRENT YEAR.--Maximum discharge during period of seasonal operation, $6.1 \mathrm{ft}^{3} / \mathrm{s}$, Aug. 14, gage height, $1.45 \mathrm{ft}$.

DISCHARGE, CUBIC FEET PER SECOND

WATER YEAR OCTOBER 2003 TO SEPTEMBER 2004

\begin{tabular}{|c|c|c|c|c|c|c|c|c|c|c|c|c|}
\hline DAY & OCT & NOV & DEC & JAN & FEB & MAR & APR & MAY & JUN & JUL & AUG & SEP \\
\hline 1 & 0.00 & 0.00 & 0.00 & --- & --- & --- & 0.00 & 0.00 & 0.00 & 0.00 & 0.00 & 0.00 \\
\hline 2 & 0.00 & 0.00 & --- & --- & --- & --- & 0.01 & 0.00 & 0.00 & 0.00 & 0.00 & 0.00 \\
\hline 3 & 0.00 & 0.00 & --- & --- & --- & --- & 0.06 & 0.00 & 0.00 & 0.00 & 0.00 & 0.00 \\
\hline 4 & 0.00 & 0.00 & --- & --- & --- & 0.01 & 0.04 & 0.00 & 0.00 & 0.00 & 0.01 & 0.00 \\
\hline 5 & 0.00 & 0.00 & --- & --- & --- & 0.00 & 0.00 & 0.00 & 0.00 & 0.00 & 0.00 & 0.00 \\
\hline 6 & 0.00 & 0.00 & --- & --- & --- & 0.00 & 0.00 & 0.00 & 0.00 & 0.00 & 0.02 & 0.00 \\
\hline 7 & 0.02 & 0.00 & --- & --- & --- & 0.00 & 0.00 & 0.00 & 0.00 & 0.00 & 0.00 & 0.00 \\
\hline 8 & 0.00 & 0.00 & --- & --- & --- & 0.00 & 0.02 & 0.00 & 0.00 & 0.00 & 0.00 & 0.00 \\
\hline 9 & 0.00 & 0.00 & --- & --- & --- & 0.00 & 0.00 & 0.00 & 0.00 & 0.00 & 0.00 & 0.00 \\
\hline 10 & 0.00 & 0.00 & --- & --- & --- & 0.00 & 0.01 & 0.00 & 0.00 & 0.00 & 0.00 & 0.00 \\
\hline 11 & 0.00 & 0.00 & --- & --- & --- & 0.00 & 0.00 & 0.00 & 0.00 & 0.00 & 0.00 & 0.00 \\
\hline 12 & 0.00 & 0.01 & --- & --- & --- & 0.00 & 0.00 & 0.00 & 0.00 & 0.00 & 0.00 & 0.00 \\
\hline 13 & 0.00 & 0.00 & --- & --- & --- & 0.00 & 0.00 & 0.00 & 0.00 & 0.00 & 0.00 & 0.00 \\
\hline 14 & 0.00 & 0.00 & --- & --- & --- & 0.00 & 0.00 & 0.00 & 0.00 & 0.00 & 0.06 & 0.00 \\
\hline 15 & 0.00 & 0.00 & --- & --- & --- & 0.00 & 0.00 & 0.00 & 0.00 & 0.00 & 0.00 & 0.00 \\
\hline 16 & 0.00 & 0.00 & --- & --- & --- & 0.00 & 0.00 & 0.00 & 0.00 & 0.00 & 0.00 & 0.00 \\
\hline 17 & 0.00 & 0.00 & --- & --- & --- & 0.00 & 0.00 & 0.00 & 0.00 & 0.00 & 0.00 & 0.00 \\
\hline 18 & 0.00 & 0.00 & --- & --- & --- & 0.00 & 0.00 & 0.00 & 0.00 & 0.00 & 0.00 & 0.00 \\
\hline 19 & 0.00 & 0.00 & --- & --- & --- & 0.00 & 0.00 & 0.00 & 0.00 & 0.00 & 0.00 & 0.03 \\
\hline 20 & 0.00 & 0.00 & --- & --- & --- & 0.00 & 0.00 & 0.00 & 0.00 & 0.00 & 0.00 & 0.00 \\
\hline 21 & 0.00 & 0.00 & --- & --- & --- & 0.00 & 0.00 & 0.00 & 0.00 & 0.00 & 0.00 & 0.00 \\
\hline 22 & 0.00 & 0.00 & --- & --- & --- & 0.00 & 0.00 & 0.00 & 0.00 & 0.00 & 0.00 & 0.00 \\
\hline 23 & 0.00 & 0.00 & --- & --- & --- & 0.00 & 0.00 & 0.00 & 0.00 & 0.00 & 0.00 & 0.00 \\
\hline 24 & 0.00 & 0.00 & --- & --- & --- & 0.00 & 0.00 & 0.00 & 0.00 & 0.03 & 0.00 & 0.00 \\
\hline 25 & 0.00 & 0.00 & --- & --- & --- & 0.00 & 0.00 & 0.00 & 0.00 & 0.00 & 0.00 & 0.00 \\
\hline 26 & 0.00 & 0.00 & --- & --- & --- & 0.00 & 0.00 & 0.00 & 0.00 & 0.00 & 0.00 & 0.00 \\
\hline 27 & 0.00 & 0.00 & --- & --- & --- & 0.00 & 0.00 & 0.00 & 0.00 & 0.02 & 0.00 & 0.00 \\
\hline 28 & 0.00 & 0.00 & --- & --- & --- & 0.00 & 0.00 & 0.00 & 0.00 & 0.00 & 0.00 & 0.00 \\
\hline 29 & 0.00 & 0.00 & --- & --- & --- & 0.00 & 0.00 & 0.00 & 0.01 & 0.00 & 0.00 & 0.00 \\
\hline 30 & 0.00 & 0.00 & --- & --- & --- & 0.00 & 0.00 & 0.00 & 0.00 & 0.00 & 0.00 & 0.00 \\
\hline 31 & 0.00 & --- & --- & --- & --- & 0.00 & --- & 0.00 & --- & 0.00 & 0.00 & --- \\
\hline ГOTAL & 0.02 & 0.01 & --- & --- & --- & --- & 0.14 & 0.00 & 0.01 & 0.05 & 0.09 & 0.03 \\
\hline MEAN & 0.00 & 0.00 & --- & --- & --- & --- & 0.00 & 0.00 & 0.00 & 0.00 & 0.00 & 0.00 \\
\hline MAX & 0.02 & 0.01 & --- & --- & --- & --- & 0.06 & 0.00 & 0.01 & 0.03 & 0.06 & 0.03 \\
\hline MIN & 0.00 & 0.00 & --- & --- & --- & --- & 0.00 & 0.00 & 0.00 & 0.00 & 0.00 & 0.00 \\
\hline AC-FT & 0.04 & 0.02 & --- & --- & --- & --- & 0.3 & 0.00 & 0.02 & 0.1 & 0.2 & 0.06 \\
\hline
\end{tabular}




\section{NORTH FLOODWAY CHANNEL NEAR ALAMEDA, NEW MEXICO}

\section{STATION ANALYSIS}

\section{WATER YEAR 2004}

Equipment.-- This station was established in July 1968. Since August 1998, an electronic datalogger with satellite transmitter and pressure transducer have been housed in a concrete 6- X 6-foot block shelter. A painted staff gage on the channel sidewall is the reference gage, which indicates the true vertical depth in the channel. A tipping-bucket rain gage, recording in 0.01-inch increments, was installed on the roof of the shelter on December 8, 2001. Both water-stage and rainfall data are recorded on 5-minute intervals. An ISCO automatic pump sampler is also housed in the shelter for water-quality sampling.

Gage-Height Record.--The recorder, referenced to the outside staff gage, gave a complete and satisfactory record for water year 2004 except for the following periods. Ice-affected gage heights occurred on November 22-25, and December 5, 14-31, 2003, and on January 1-7, 23-29, and February 1-10, 13-14, 2004. All days, except the rainy day of January 25, were considered base flow ( 0.5 to 2.0 cubic feet per second) because no precipitation occurred during these periods. Daily mean discharges were estimated for October 19-20, 2003 when the orifice pipe had been twisted out of the water and for the period November 11-18 when the recorder malfunctioned. Sand and debris are commonly transported by the North Floodway channel and it often-times catches on the pressure transducer orifice pipe or, because the orifice is mounted in a depression below the channel bottom elevation, accumulates in the orifice sump during flows. Erroneous gage height recordings result in either case and can cause recordings to drift higher or lower than true flow depths. The periods February 26 and July 1-7 experienced such "silting" problems, so their daily mean discharges were estimated. No precipitation fell during these estimated days so only base flows were expected ( 0.5 to 2.0 cubic feet per second). Very commonly the "silting" occurs during the receeding limb of a hydrograph so a gage height trace can be estimated by graphical methods. Estimated mean daily discharges are based on hydrographic comparison with a flow gage located approximately 5 miles upstream at the Candelaria bridge (N. Floodway at Albq. \#08329835), precipitation records, and base flows before and after the estimated time periods. Occasionally, gage height recordings are slightly affected by debris accumulations after a flow event, but not to the extent of the "estimated" days. In this situation, graphing recorded gage heights clearly shows erroneous readings and the trace of actual flow depths is estimated with little loss in accuracy. The following dates experienced such minor gage height corrections, but were not labeled as "estimated" discharges: February 22-23, 27, March 3, 5, April 9, 11-13, 28, 30, May 11, June 1, 18, 27-28, July 13, 23, 26, August 5, 20, 30, and September 7, 24, and 30, 2004.

Rating.--The control for this station is the concrete-lined channel. The bottom width of the channel is 25 feet. The side slopes are approximately 35 degrees from horizontal. The depth of the channel at this point is about 23 feet, and top width is approximately 117 feet. 
During water year 2004, 130 site visits and observations were made at this gaging station, ranging from storm-flows to base-flows.

Rating 1.0, used during water years 1968-99, was replotted in water year 2000, using only 2 points. The rating curve of a trapezoidal-shaped, concrete-lined channel with uniform side walls, such as the North Floodway, should plot as a straight line. The new plot was labeled rating 2.0. The old rating 1.0 had been plotted with many input points, resulting in an irregular line plot. The two ratings varied by less than 2 percent, except below 25 cubic feet per second, for which they vary by about 5 percent.

In water year 2001, the channel was resurveyed and the step-backwater analysis was recomputed using the software package HECRAS. Low-flow measurements prior to water year 2001 and four measurements (42-45) completed in December 2001 were also plotted on the new step-backwater rating. A new rating, 3.0, was developed and is significantly different from the previous ratings. The new rating 3.0 computes discharges over 100 percent less than the old rating at low flows, and about 35 percent less discharge is computed at a 2.00-foot stage ( 560 cubic feet per second). Rating 3.0 discharge actually equals the old rating discharge at a stage of approximately 8.0 feet $(7,400$ cubic feet per second). Also, rating 3.0 closely parallels the original design rating developed by the Corps of Engineers for planning purposes. The new rating computes discharges for all gage heights more than 0.01 foot deep ( 0.7 cubic feet per second), whereas the old rating did not compute flows less than 14.5 cubic feet per second (less than 0.14 -foot stages). Three of the four new measurements completed in December 2001 plotted less than 10 percent different from the new rating. The poorly rated, very low flow measurement 44 plotted a negative 63 percent from the rated discharge. All four measurements completed in water year 2003 plot negative 8 to negative 20 percent from rating 3.0. The inherent errors in measuring very shallow water lead to the slight misfit from the new rating line. No shifting occurs in this concrete-lined channel because high flow velocities keep the channel bottom clear of sediment. Supercritical flow regimes occur here at all stages over 1.00 foot. Prior water year records have been revised using the new rating 3.0.

Discharge.--Discharge was computed using rating 3.0 directly. The rating curve discharge is considered to be better than any individual measurements. Wading at this site would be very dangerous at anything over 0.2 -foot depths because of extreme velocities and floating debris during storm events. Bridge measurements are also not possible. Baseflow measurements are completed about 1000 feet downstream at the old low-flow gaging station (08329916), where flow is constricted. The low-flow gage was used to record discharges less than 15 cubic feet per second; these discharges were combined with this station's storm flows to complete the daily values table published in the USGS Annual Water-Data Reports for water years 1997-99.

The maximum gage height and discharge for the water year were 7.00 feet and 5,700 cubic feet per second, respectively, on July 23, 2004. 
RIO GRANDE BASIN

08329900 NORTH FLOODWAY CHANNEL NEAR ALAMEDA, NM

LOCATION.--Lat 35 11'53", long 106³5'59", Bernalillo County, Hydrologic Unit 13020203, in Elena Gallegos Grant, on left bank 0.5 mi upstream from Edith Boulevard, $1.1 \mathrm{mi}$ upstream from mouth, and $1.2 \mathrm{mi}$ northeast of Alameda.

DRAINAGE AREA.--87.9 $\mathrm{mi}^{2}$.

PERIOD OF RECORD.--July 1968 to September 1989 (seasonal records). October 1989 to current year.

GAGE.--Water-stage recorder with satellite telemetry, recording rain gage, and concrete-lined channel. Elevation of gage is $5,015 \mathrm{ft}$ above National Geodetic Vertical Datum of 1929, from U.S. Army Corps of Engineers plan and profile map. Recording tipping-bucket rain gage, recording in 0.01-in. increments, since Dec. 8, 2001.

REMARKS.--Water-discharge records good except for those estimated, which are poor. For water years $1997-99$, low-flow values of $15 \mathrm{ft}^{3} / \mathrm{s}$ or less were obtained from gaging station (08329914), 1,000 ft downstream. Prior to water year 1997, any discharges below $15 \mathrm{ft}^{3}$ /s were reported as "zero flow" in the mean daily values tables. Floodway channel intercepts flow of numerous arroyos in northeast Albuquerque and discharges into the Rio Grande at a point 1.6 mi north of Alameda. See tabulation below for monthly precipitation, in inches.

DISCHARGE, CUBIC FEET PER SECOND

WATER YEAR OCTOBER 2003 TO SEPTEMBER 2004

\begin{tabular}{|c|c|c|c|c|c|c|c|c|c|c|c|c|}
\hline \multicolumn{13}{|c|}{ MEAN VALUES } \\
\hline DAY & OCT & $\mathrm{NOV}$ & DEC & JAN & FEB & MAR & APR & MAY & JUN & JUL & AUG & SEP \\
\hline 1 & 1.5 & 1.7 & 3.3 & e1.0 & $\mathrm{e} 1.0$ & 1.5 & 1.2 & 0.73 & 1.2 & $\mathrm{e} 2.0$ & 0.13 & 2.0 \\
\hline 2 & 3.2 & 1.5 & 1.7 & e1.0 & e1.0 & 6.5 & 54 & 0.72 & 1.2 & e1.0 & 6.8 & 1.9 \\
\hline 3 & 3.1 & 1.1 & 1.9 & $\mathrm{e} 1.0$ & $\mathrm{e} 1.0$ & 6.2 & 309 & 1.0 & 2.8 & $\mathrm{e} 1.0$ & 9.9 & 1.5 \\
\hline 4 & 4.6 & 1.1 & 1.8 & e1.0 & $\mathrm{e} 1.0$ & 229 & 62 & 0.95 & 1.2 & $\mathrm{e} 1.0$ & 172 & 10 \\
\hline 5 & 1.9 & 1.0 & e1.5 & e1.0 & e1.0 & 36 & 5.7 & 1.0 & 1.2 & e1.0 & 13 & 7.9 \\
\hline 6 & 3.2 & e1.0 & 1.7 & e1.0 & e1.0 & 2.9 & 2.7 & 1.9 & 0.76 & e1.0 & 2.6 & 3.3 \\
\hline 7 & 262 & $\mathrm{e} 1.0$ & 2.0 & $\mathrm{e} 1.0$ & $\mathrm{e} 1.0$ & 1.9 & 1.9 & 6.5 & 1.0 & $\mathrm{e} 1.0$ & 1.8 & 1.2 \\
\hline 8 & 85 & $\mathrm{e} 1.5$ & 2.1 & 0.65 & e1.0 & 1.1 & 83 & 3.5 & 0.92 & 1.8 & 0.96 & 1.1 \\
\hline 9 & 3.2 & e2.0 & 1.7 & 0.52 & e1.0 & 2.3 & 17 & 2.6 & 0.99 & 0.50 & 1.5 & 1.2 \\
\hline 10 & 31 & e1.0 & 1.6 & 0.53 & e1.0 & 1.1 & 55 & 2.4 & 1.1 & 0.11 & 52 & 1.2 \\
\hline 11 & 34 & e1.0 & 1.5 & 1.1 & 1.5 & 1.1 & 11 & 1.3 & 0.97 & 22 & 4.9 & 1.2 \\
\hline 12 & 11 & e112 & 13 & 0.83 & 0.72 & 0.94 & 1.6 & 3.9 & 1.2 & 185 & 2.9 & 1.9 \\
\hline 13 & 7.3 & e35 & 4.1 & 0.86 & $\mathrm{e} 1.0$ & 0.76 & 0.52 & 1.4 & 1.1 & 11 & 3.4 & 3.1 \\
\hline 14 & 5.5 & e1.5 & $\mathrm{e} 2.0$ & 0.74 & e1.0 & 0.45 & 0.66 & 1.0 & 2.9 & 11 & 1.4 & 1.3 \\
\hline 15 & 2.0 & e1.5 & e 1.5 & 1.5 & 1.8 & 0.49 & 2.4 & 0.86 & 1.1 & 88 & 0.99 & 1.8 \\
\hline 16 & 2.3 & e2.0 & e1.5 & 2.3 & 1.8 & 0.13 & 0.64 & 1.1 & 0.86 & 6.3 & 1.5 & 1.3 \\
\hline 17 & 2.6 & $\mathrm{e} 2.0$ & $\mathrm{e} 1.5$ & 1.3 & 1.9 & 1.0 & 0.89 & 1.6 & 2.2 & 0.55 & 1.1 & 1.2 \\
\hline 18 & 1.0 & e2.0 & e1.0 & 1.9 & 1.5 & 0.74 & 0.64 & 1.4 & 1.5 & 0.85 & 1.9 & 1.5 \\
\hline 19 & $\mathrm{e} 1.5$ & 2.1 & $\mathrm{e} 1.0$ & 2.6 & 1.4 & 0.67 & 0.85 & 1.3 & 0.87 & 0.70 & 8.4 & 214 \\
\hline 20 & e 1.0 & 1.3 & e1.0 & 8.5 & 1.7 & 0.79 & 0.57 & 1.2 & 0.86 & 18 & 3.6 & 33 \\
\hline 21 & 1.8 & 2.1 & e1.0 & 3.2 & 11 & 0.63 & 3.3 & 1.2 & 0.93 & 0.45 & 1.3 & 2.2 \\
\hline 22 & 1.7 & $\mathrm{e} 1.5$ & e 1.0 & 0.97 & 5.8 & 0.95 & 0.43 & 1.2 & 1.8 & 54 & 3.9 & 0.46 \\
\hline 23 & 1.8 & e1.5 & e1.0 & e1.0 & 225 & 0.87 & 0.73 & 0.90 & 4.5 & 371 & 2.7 & 0.61 \\
\hline 24 & 1.5 & e1.5 & e1.0 & e1.0 & 117 & 3.1 & 1.00 & 1.2 & 1.1 & 34 & 1.4 & 1.1 \\
\hline 25 & 1.2 & e1.5 & e1.0 & e10 & 1.2 & 1.3 & 0.88 & 1.2 & 1.2 & 134 & 2.1 & 1.2 \\
\hline 26 & 1.5 & 2.1 & e1.0 & e1.0 & e1.0 & 1.2 & 1.7 & 1.5 & 34 & 1.8 & 1.5 & 1.2 \\
\hline 27 & 1.8 & 1.5 & e1.0 & e1.0 & 0.73 & 0.92 & 1.9 & 1.3 & 6.8 & 124 & 1.6 & 1.9 \\
\hline 28 & 1.7 & 1.9 & e1.0 & e1.0 & 30 & 0.50 & 0.41 & 1.2 & 21 & 16 & 1.4 & 1.6 \\
\hline 29 & 1.7 & 1.9 & e1.0 & e1.0 & 1.3 & 1.2 & 1.8 & 0.71 & 135 & 2.6 & 2.1 & 24 \\
\hline 30 & 1.3 & 2.9 & e1.0 & 1.00 & --- & 0.97 & 0.61 & 0.62 & 18 & 0.53 & 2.1 & 7.4 \\
\hline 31 & 0.91 & --- & e1.0 & 1.1 & --- & 0.74 & --- & 1.3 & --- & 0.28 & 1.9 & --- \\
\hline OTAL & 483.81 & 191.7 & 58.4 & 52.60 & 417.35 & 307.95 & 624.03 & 48.69 & 250.26 & $1,092.47$ & 312.78 & 333.27 \\
\hline UEAN & 15.6 & 6.39 & 1.88 & 1.70 & 14.4 & 9.93 & 20.8 & 1.57 & 8.34 & 35.2 & 10.1 & 11.1 \\
\hline AAX & 262 & 112 & 13 & 10 & 225 & 229 & 309 & 6.5 & 135 & 371 & 172 & 214 \\
\hline MIN & 0.91 & 1.0 & 1.0 & 0.52 & 0.72 & 0.13 & 0.41 & 0.62 & 0.76 & 0.11 & 0.13 & 0.46 \\
\hline IC-FT & 960 & 380 & 116 & 104 & 828 & 611 & 1,240 & 97 & 496 & 2,170 & 620 & 661 \\
\hline +) & 1.11 & 0.83 & 0.16 & 0.19 & 1.27 & 0.87 & 1.98 & 0.00 & 0.69 & 1.76 & 0.49 & 1.16 \\
\hline
\end{tabular}

STATISTICS OF MONTHLY MEAN DATA FOR WATER YEARS 1990 - 2004, BY WATER YEAR (WY)

\begin{tabular}{|c|c|c|c|c|c|c|c|c|c|c|c|c|}
\hline MEAN & 11.4 & 6.61 & 2.63 & 3.23 & 4.41 & 8.72 & 8.68 & 7.19 & 8.61 & 22.8 & 27.5 & 14.6 \\
\hline MAX & 38.3 & 16.9 & 8.32 & 14.2 & 16.3 & 21.3 & 42.9 & 30.5 & 25.0 & 67.9 & 45.7 & 34.5 \\
\hline (WY) & (2001) & (1995) & (1994) & (1995) & (1993) & (2000) & (1997) & (1994) & (1996) & (1997) & (1994) & (1991) \\
\hline MIN & 2.16 & 0.00 & 0.00 & 0.00 & 0.00 & 0.55 & 0.78 & 0.92 & 1.42 & 1.17 & 6.54 & 2.15 \\
\hline (WY) & (1996) & (1990) & (1990) & (1990) & (1991) & (1991) & $(2000)$ & (1998) & (1998) & (2003) & (2003) & 2000) \\
\hline
\end{tabular}

\section{SUMMARY STATISTICS}

ANNUAL TOTAL

HIGHEST ANNUAL MEAN

HIGHEST DAILY MEAN

LOWEST DAILY MEAN

ANNUAL SEVEN-DAY MINIMUM

MAXIMUM PEAK FLOW

MAXIMUM PEAK STAGE

ANNUAL RUNOFF (AC-FT)

10 PERCENT EXCEEDS

50 PERCENT EXCEEDS

90 PERCENT EXCEEDS
FOR 2003 CALENDAR YEAR

$\begin{array}{cc}2,317.41 & \\ 6.35 & \\ & \\ 266 & \text { Mar 21 } \\ 0.00 & \text { Feb 17 } \\ 0.03 & \text { Mar 26 } \\ & \\ & \\ 4,600 & \\ 9.5 & \\ 1.5 & \\ 0.09 & \end{array}$

FOR 2004 WATER YEAR

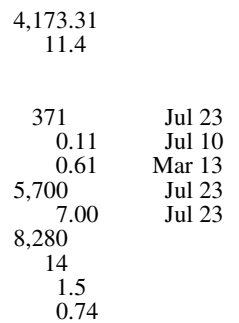

WATER YEARS 1990 - 2004

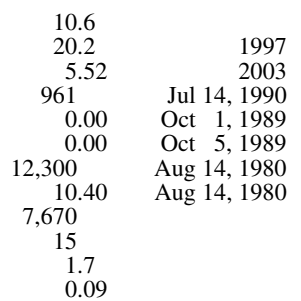

(+) Total precipitation accumulation, in inches.

e Estimated 


\section{NORTH CAMINO ARROYO AT SUNSET HILLS IN ALBUQUERQUE, NEW MEXICO}

\section{STATION ANALYSIS}

\section{WATER YEAR 2004}

Equipment.--An electronic datalogger and pressure transducer, recording on 5-minute intervals, are housed in a metal 2.5 - by 2.5 - by 5.5 -foot shelter anchored to a concrete slab on the right bank of the concrete-lined channel. An outside staff gage is painted on the right sidewall of the channel for reference. High-water measurements are determined by indirect methods. A crest-stage gage was installed on October 23, 1998, and is 0.42 foot above the bottom of the channel and mounted 32 degrees from horizontal.

Gage-Height Record.-- The water-stage recorder is referenced to the channel bottom or to the outside staff during flows. When the orifice sump is filled with water to the level of the channel bottom, or point of zero flow, the recorded gage height is 1.00 foot. The datalogger gave a complete and satisfactory record for water year 2004, except for September 19-20 when the nitrogen supply to the pressure transducer was accidentally shut off. Daily mean discharges for these two days were estimated based on precipitation accumulation at rain gages in the upper drainage basin. The gage will remain dry unless significant precipitation falls in the watershed. The station was not operated for the winter period December 5, 2003, to March 9, 2004..

Rating.-- The trapezoidal-shaped channel is straight for approximately 0.50 mile upstream from the gage and bends sharply to the right approximately 20 feet below the gage. Because flow regimes are supercritical in this steep channel, the downstream channel geometry is not necessary to compute the theoretical rating. The channel bottom is approximately 21 feet wide at the gage and has side walls about 7 feet high. The channel bottom is sloped towards the right bank (orifice side) at the gage.

Rating 1.0 was developed by a step-forward theoretical analysis during the 1997 water year. Because of extremely high flow velocities, discharge measurements at this site are nearly impossible with the current technology. Flows are very flashy, lasting less than an hour, so mean daily discharges are very small relative to the instantaneous peak discharges.

Discharge.-- Rating 1.0 was used directly, without any shifts, for water year 2004. This site will remain dry unless significant precipitation falls in the watershed. During water year 2004, 12 no-flow inspections were made at this site. The maximum instantaneous gage height and discharge for the water year were 1.20 feet and 10 cubic feet per second, respectively, on June 29, 2004. 
LOCATION.--Lat $35^{\circ} 11^{\prime} 40^{\prime \prime}$, long $106^{\circ} 31^{\prime} 57^{\prime \prime}$, Bernalillo County, Hydrologic Unit 13020203, in Elena Gallegos Grant, on right bank of concrete-lined arroyo, 10 $\mathrm{ft}$ above Holbrook Ave. bridge over North Camino Arroyo. This is located approximately $100 \mathrm{ft}$ north of intersection of Holbrook Ave. and Elena Drive, and 1.3 mi north of Paseo del Norte, on the northern edge of Albuquerque.

DRAINAGE AREA.--2.06 $\mathrm{mi}^{2}$

PERIOD OF RECORD.--August 1997 to current year (seasonal records).

GAGE.--Water-stage recorder. Elevation of gage is 5,645 ft above National Geodetic Vertical Datum of 1929, from topographic map.

REMARKS.--Records good except for those estimated, which are poor.

EXTREMES FOR PERIOD OF RECORD.--Maximum discharge, $39 \mathrm{ft}^{3} / \mathrm{s}$, at 1955 hours, July 23, 2001, gage height, $1.38 \mathrm{ft}$, from step-forward analysis of concretelined stream channel; no flow most of time.

EXTREMES FOR CURRENT YEAR.--Maximum discharge during period of seasonal operation, $10 \mathrm{ft}^{3} / \mathrm{s}$, June 29 , gage height, $1.20 \mathrm{ft}$; no flow most of time.

DISCHARGE, CUBIC FEET PER SECOND

WATER YEAR OCTOBER 2003 TO SEPTEMBER 2004

DAILY MEAN VALUES

\begin{tabular}{|c|c|c|c|c|c|c|c|c|c|c|c|c|}
\hline DAY & OCT & NOV & DEC & JAN & FEB & MAR & APR & MAY & JUN & JUL & AUG & SEP \\
\hline $\begin{array}{l}1 \\
2 \\
3 \\
4 \\
5\end{array}$ & $\begin{array}{l}0.00 \\
0.00 \\
0.03 \\
0.07 \\
0.00\end{array}$ & $\begin{array}{l}0.00 \\
0.00 \\
0.00 \\
0.00 \\
0.00\end{array}$ & $\begin{array}{l}0.00 \\
0.00 \\
0.00 \\
0.00 \\
0.00\end{array}$ & $\begin{array}{l}--- \\
--- \\
--- \\
---\end{array}$ & $\begin{array}{l}--- \\
--- \\
-- \\
-- \\
--\end{array}$ & $\begin{array}{l}--- \\
--- \\
--- \\
--- \\
--\end{array}$ & $\begin{array}{l}0.00 \\
0.42 \\
0.66 \\
0.23 \\
0.00\end{array}$ & $\begin{array}{l}0.00 \\
0.00 \\
0.00 \\
0.00 \\
0.00\end{array}$ & $\begin{array}{l}0.00 \\
0.00 \\
0.00 \\
0.00 \\
0.00\end{array}$ & $\begin{array}{l}0.00 \\
0.00 \\
0.00 \\
0.00 \\
0.00\end{array}$ & $\begin{array}{l}0.00 \\
0.03 \\
0.00 \\
0.05 \\
0.01\end{array}$ & $\begin{array}{l}0.00 \\
0.00 \\
0.00 \\
0.03 \\
0.00\end{array}$ \\
\hline $\begin{array}{r}6 \\
7 \\
8 \\
9 \\
10\end{array}$ & $\begin{array}{l}0.00 \\
0.24 \\
0.19 \\
0.00 \\
0.02\end{array}$ & $\begin{array}{l}0.00 \\
0.00 \\
0.00 \\
0.00 \\
0.00\end{array}$ & $\begin{array}{l}--- \\
--- \\
--- \\
--- \\
--\end{array}$ & $\begin{array}{l}--- \\
--- \\
--- \\
-- \\
--\end{array}$ & $\begin{array}{l}--- \\
--- \\
--- \\
--- \\
---\end{array}$ & $\begin{array}{l}--- \\
--- \\
--- \\
0.00 \\
0.00\end{array}$ & $\begin{array}{l}0.00 \\
0.00 \\
0.14 \\
0.09 \\
0.11\end{array}$ & $\begin{array}{l}0.00 \\
0.00 \\
0.00 \\
0.00 \\
0.00\end{array}$ & $\begin{array}{l}0.00 \\
0.00 \\
0.00 \\
0.00 \\
0.00\end{array}$ & $\begin{array}{l}0.00 \\
0.00 \\
0.00 \\
0.00 \\
0.00\end{array}$ & $\begin{array}{l}0.00 \\
0.00 \\
0.00 \\
0.00 \\
0.00\end{array}$ & $\begin{array}{l}0.00 \\
0.00 \\
0.00 \\
0.00 \\
0.00\end{array}$ \\
\hline $\begin{array}{l}11 \\
12 \\
13 \\
14 \\
15\end{array}$ & $\begin{array}{l}0.01 \\
0.00 \\
0.00 \\
0.00 \\
0.00\end{array}$ & $\begin{array}{l}0.00 \\
0.20 \\
0.18 \\
0.00 \\
0.00\end{array}$ & $\begin{array}{l}--- \\
--- \\
--- \\
--- \\
---\end{array}$ & $\begin{array}{l}--- \\
-- \\
-- \\
--- \\
--\end{array}$ & $\begin{array}{l}--- \\
--- \\
-- \\
-- \\
--\end{array}$ & $\begin{array}{l}0.00 \\
0.00 \\
0.00 \\
0.00 \\
0.00\end{array}$ & $\begin{array}{l}0.00 \\
0.00 \\
0.00 \\
0.00 \\
0.00\end{array}$ & $\begin{array}{l}0.00 \\
0.00 \\
0.00 \\
0.00 \\
0.00\end{array}$ & $\begin{array}{l}0.00 \\
0.00 \\
0.00 \\
0.00 \\
0.00\end{array}$ & $\begin{array}{l}0.00 \\
0.39 \\
0.00 \\
0.00 \\
0.00\end{array}$ & $\begin{array}{l}0.00 \\
0.00 \\
0.00 \\
0.00 \\
0.00\end{array}$ & $\begin{array}{l}0.00 \\
0.00 \\
0.00 \\
0.00 \\
0.00\end{array}$ \\
\hline $\begin{array}{l}16 \\
17 \\
18 \\
19 \\
20\end{array}$ & $\begin{array}{l}0.00 \\
0.00 \\
0.00 \\
0.00 \\
0.00\end{array}$ & $\begin{array}{l}0.02 \\
0.01 \\
0.00 \\
0.00 \\
0.00\end{array}$ & $\begin{array}{l}--- \\
--- \\
--- \\
--- \\
---\end{array}$ & $\begin{array}{l}--- \\
-- \\
--- \\
--- \\
--\end{array}$ & $\begin{array}{l}--- \\
--- \\
--- \\
--- \\
---\end{array}$ & $\begin{array}{l}0.00 \\
0.00 \\
0.00 \\
0.00 \\
0.00\end{array}$ & $\begin{array}{l}0.00 \\
0.00 \\
0.00 \\
0.00 \\
0.00\end{array}$ & $\begin{array}{l}0.00 \\
0.00 \\
0.00 \\
0.00 \\
0.00\end{array}$ & $\begin{array}{l}0.00 \\
0.00 \\
0.00 \\
0.00 \\
0.00\end{array}$ & $\begin{array}{l}0.00 \\
0.00 \\
0.01 \\
0.00 \\
0.03\end{array}$ & $\begin{array}{l}0.00 \\
0.00 \\
0.01 \\
0.00 \\
0.00\end{array}$ & $\begin{array}{r}0.00 \\
0.00 \\
0.00 \\
\mathrm{e} 0.10 \\
\mathrm{e} 0.01\end{array}$ \\
\hline $\begin{array}{l}21 \\
22 \\
23 \\
24 \\
25\end{array}$ & $\begin{array}{l}0.00 \\
0.00 \\
0.00 \\
0.00 \\
0.00\end{array}$ & $\begin{array}{l}0.00 \\
0.00 \\
0.00 \\
0.00 \\
0.00\end{array}$ & $\begin{array}{l}--- \\
-- \\
--- \\
--- \\
--\end{array}$ & $\begin{array}{l}--- \\
-- \\
-- \\
--- \\
---\end{array}$ & $\begin{array}{l}--- \\
--- \\
-- \\
-- \\
---\end{array}$ & $\begin{array}{l}0.00 \\
0.00 \\
0.03 \\
0.04 \\
0.00\end{array}$ & $\begin{array}{l}0.00 \\
0.00 \\
0.00 \\
0.00 \\
0.00\end{array}$ & $\begin{array}{l}0.00 \\
0.00 \\
0.00 \\
0.00 \\
0.00\end{array}$ & $\begin{array}{l}0.00 \\
0.00 \\
0.00 \\
0.00 \\
0.00\end{array}$ & $\begin{array}{l}0.00 \\
0.00 \\
0.19 \\
0.05 \\
0.07\end{array}$ & $\begin{array}{l}0.03 \\
0.00 \\
0.00 \\
0.00 \\
0.00\end{array}$ & $\begin{array}{l}0.00 \\
0.00 \\
0.00 \\
0.00 \\
0.00\end{array}$ \\
\hline $\begin{array}{l}26 \\
27 \\
28 \\
29 \\
30 \\
31\end{array}$ & $\begin{array}{l}0.00 \\
0.00 \\
0.00 \\
0.00 \\
0.00 \\
0.00\end{array}$ & $\begin{array}{c}0.00 \\
0.00 \\
0.00 \\
0.00 \\
0.00 \\
---\end{array}$ & $\begin{array}{l}--- \\
--- \\
--- \\
--- \\
--- \\
---\end{array}$ & $\begin{array}{l}--- \\
--- \\
--- \\
--- \\
--- \\
---\end{array}$ & $\begin{array}{l}--- \\
--- \\
--- \\
--- \\
--- \\
---\end{array}$ & $\begin{array}{l}0.00 \\
0.00 \\
0.00 \\
0.00 \\
0.00 \\
0.00\end{array}$ & $\begin{array}{l}0.00 \\
0.00 \\
0.00 \\
0.00 \\
0.00 \\
---\end{array}$ & $\begin{array}{l}0.00 \\
0.00 \\
0.00 \\
0.00 \\
0.00 \\
0.00\end{array}$ & $\begin{array}{c}0.05 \\
0.00 \\
0.00 \\
0.34 \\
0.00 \\
---\end{array}$ & $\begin{array}{l}0.00 \\
0.11 \\
0.00 \\
0.00 \\
0.00 \\
0.00\end{array}$ & $\begin{array}{l}0.00 \\
0.00 \\
0.00 \\
0.00 \\
0.00 \\
0.00\end{array}$ & $\begin{array}{l}0.02 \\
0.00 \\
0.00 \\
0.08 \\
0.00 \\
---\end{array}$ \\
\hline $\begin{array}{l}\text { TOTAL } \\
\text { MEAN } \\
\text { MAX } \\
\text { MIN } \\
\text { AC-FT }\end{array}$ & $\begin{array}{l}0.56 \\
0.02 \\
0.24 \\
0.00 \\
1.1\end{array}$ & $\begin{array}{l}0.41 \\
0.01 \\
0.20 \\
0.00 \\
0.8\end{array}$ & $\begin{array}{l}--- \\
--- \\
--- \\
---\end{array}$ & $\begin{array}{l}--- \\
-- \\
--- \\
--- \\
--\end{array}$ & $\begin{array}{l}--- \\
--- \\
--- \\
-- \\
---\end{array}$ & $\begin{array}{l}--- \\
--- \\
--- \\
---\end{array}$ & $\begin{array}{l}1.65 \\
0.06 \\
0.66 \\
0.00 \\
3.3\end{array}$ & $\begin{array}{l}0.00 \\
0.00 \\
0.00 \\
0.00 \\
0.00\end{array}$ & $\begin{array}{l}0.39 \\
0.01 \\
0.34 \\
0.00 \\
0.8\end{array}$ & $\begin{array}{l}0.85 \\
0.03 \\
0.39 \\
0.00 \\
1.7\end{array}$ & $\begin{array}{l}0.13 \\
0.00 \\
0.05 \\
0.00 \\
0.3\end{array}$ & $\begin{array}{l}0.24 \\
0.01 \\
0.10 \\
0.00 \\
0.5\end{array}$ \\
\hline
\end{tabular}

e Estimated 


\section{CALABACILLAS ARROYO BELOW COORS BOULEVARD AT ALBUQUERQUE, NEW MEXICO}

\section{STATION ANALYSIS}

\section{WATER YEAR 2004}

Equipment.-- This recording crest-stage gage was established in July 2003. A Win-situ Minitroll electronic datalogger and pressure transducer combination are housed in a 6-foot vertical 12inch diameter iron pipe shelter that is concreted into the ground immediately upstream of the concrete equipment crossing. Water-stage is recorded on 5-minute intervals. The instrument is mounted on a 2-inch by 4-inch board which also acts as a crest-stage gage recording the highwater mark of each flow. The gage is approximately 0.4 miles downstream from Coors Blvd. and approximately 500 feet upstream from the Rio Grande. A highly developed commercial area around the Cottonwood Mall drains into this arroyo approximately 0.5 miles upstream from the gage.

Gage-Height Record.--The recorder, referenced to the outside Point of Zero Flow (PZF) on the concrete equipment crossing, gave a complete and satisfactory record for water year 2004 except for March 1-2 when the recorder batteries expired. No flows or precipitation occurred during these 2 partial days and because significant rainfall in the watershed is required to produce a flow at the gage, no estimation was necessary. Very commonly, "silting" of the well occurs during the receeding limb of a hydrograph and occasionally sediment covers the probe intakes which will affect recorded gage heights. In this situation, a gage height trace can often be estimated by graphical methods. Estimated mean daily discharges are based on precipitation records and high-water marks within the well casing or on the transducer mounting board.

Rating.-- The channel slope is approximately 0.008 feet per foot and the control for this station is the sandy-bottom braided channel. The bottom width of the channel is approximately 100 feet at the gage and will shift during most flow events. Concrete embankments line both sides of the channel and are approximately 3 feet high near the gage, gradually increasing upstream to approximately 7 feet. Flows are typically very wide and shallow. The channel is straight for 2000 feet upstream and 500 feet downstream to the Rio Grande.

Stage-discharge rating 1.0 is based on a theoretical step-backwater analysis and occasionally verified by a shallow-water measurement or slope-area indirect measurement. Shifts to the rating are based on sediment depths over the PZF after each flow.

During water year 2004, 11 site visits were made at this station.

Theoretical rating 1.0 was used during the entire water year with numerous shifts that are listed on the attached "Shift Curves" worksheet. All shifts are negative and based on the depth of sediment over the PZF after each flow event. One slope-area indirect measurement was computed for the flow of June 14, 2002. It's $460 \mathrm{cfs}$. plotted -5.3 percent different from the new rating for a flow depth of 1.11 feet. Continuous shifting occurs in this braided channel. 
Discharge.--Discharge was computed using rating 1.0 with numerous negative shifts throughout the water year based on sediment depths over the PZF. The rating curve discharge is considered to be better than any individual measurements. Wading at this site would be very dangerous at any depths exceeding 1.0-foot because of high velocities and floating debris during storm events. Bridge measurements are also not possible.

The maximum gage height and discharge for water year 2004 were 1.09 feet and 363 cubic feet per second, respectively, on August 20, 2004.

Remarks.--Records fair due to the constant shifting of the channel bottom. 
RIO GRANDE BASIN

08329926 CALABACILLAS ARROYO BELOW COORS BLVD., NM

LOCATION.--Lat $35^{\circ} 11^{\prime} 15^{\prime \prime}$, long 106 39'05", Bernallio County, Hydrologic Unit 13020203, in the town of Alameda Land Grant, approximatly 0.4 mi downstream of Coors Blvd. and $500 \mathrm{ft}$ above confluence with the Rio Grande, in Albuquerque.

DRAINAGE AREA.--77.0 $\mathrm{mi}^{2}$ of natural drainage. Man-made diversions in lower part of the watershed contribute another $12.0 \mathrm{mi}^{2}$ for a total of $89.0 \mathrm{mi}^{2}$.

PERIOD OF RECORD.--July 23, 2003 to current year.

GAGE.--Mini-troll pressure transducer, recording in 5-minute intervals, is housed in a $1 \mathrm{ft}$ diameter crest-stage gage pipe. Elevation of gage is $4,995 \mathrm{ft}$ above National Geodectic Vertical Datum of 1929, from topographic map.

REMARKS.--Records fair due to constant shifting of channel bottom.

DISCHARGE, CUBIC FEET PER SECOND

WATER YEAR OCTOBER 2003 TO SEPTEMBER 2004

\begin{tabular}{|c|c|c|c|c|c|c|c|c|c|c|c|c|}
\hline DAY & OCT & NOV & DEC & JAN & FEB & MAR & APR & MAY & JUN & JUL & AUG & SEP \\
\hline 1 & 0.00 & 0.00 & 0.00 & 0.00 & 0.00 & 0.00 & 0.00 & 0.00 & 0.00 & 0.00 & 0.00 & 0.00 \\
\hline 2 & 0.00 & 0.00 & 0.00 & 0.00 & 0.00 & 0.00 & 4.7 & 0.00 & 0.00 & 0.00 & 0.00 & 0.00 \\
\hline 3 & 0.00 & 0.00 & 0.00 & 0.00 & 0.00 & 0.00 & 49 & 0.00 & 0.00 & 0.00 & 0.00 & 0.00 \\
\hline 4 & 0.00 & 0.00 & 0.00 & 0.00 & 0.00 & 6.7 & 16 & 0.00 & 0.00 & 0.00 & 0.00 & 0.00 \\
\hline 5 & 0.00 & 0.00 & 0.00 & 0.00 & 0.00 & 2.4 & 0.00 & 0.00 & 0.00 & 0.00 & 0.00 & 0.00 \\
\hline 6 & 0.00 & 0.00 & 0.00 & 0.00 & 0.00 & 0.00 & 0.00 & 0.00 & 0.00 & 0.00 & 0.00 & 0.00 \\
\hline 7 & 9.9 & 0.00 & 0.00 & 0.00 & 0.00 & 0.00 & 0.00 & 0.00 & 0.00 & 0.00 & 0.00 & 0.00 \\
\hline 8 & 0.62 & 0.00 & 0.00 & 0.00 & 0.00 & 0.00 & 17 & 0.00 & 0.00 & 0.00 & 0.00 & 0.00 \\
\hline 9 & 0.00 & 0.00 & 0.00 & 0.00 & 0.00 & 0.00 & 0.98 & 0.00 & 0.00 & 0.00 & 0.00 & 0.00 \\
\hline 10 & 0.00 & 0.00 & 0.00 & 0.00 & 0.00 & 0.00 & 12 & 0.00 & 0.00 & 0.00 & 0.00 & 0.00 \\
\hline 11 & 0.00 & 0.00 & 0.00 & 0.00 & 0.00 & 0.00 & 0.82 & 0.00 & 0.00 & 0.00 & 0.00 & 0.00 \\
\hline 12 & 0.00 & 0.74 & 0.00 & 0.00 & 0.00 & 0.00 & 0.00 & 0.00 & 0.00 & 0.00 & 0.00 & 0.00 \\
\hline 13 & 0.00 & 0.04 & 0.00 & 0.00 & 0.00 & 0.00 & 0.00 & 0.00 & 0.00 & 0.00 & 0.00 & 0.00 \\
\hline 14 & 0.00 & 0.00 & 0.00 & 0.00 & 0.00 & 0.00 & 0.00 & 0.00 & 0.00 & 0.00 & 0.00 & 0.00 \\
\hline 15 & 0.00 & 0.00 & 0.00 & 0.00 & 0.00 & 0.00 & 0.00 & 0.00 & 0.00 & 0.00 & 0.00 & 0.00 \\
\hline 16 & 0.00 & 0.00 & 0.00 & 0.00 & 0.00 & 0.00 & 0.00 & 0.00 & 0.00 & 0.00 & 0.00 & 0.00 \\
\hline 17 & 0.00 & 0.00 & 0.00 & 0.00 & 0.00 & 0.00 & 0.00 & 0.00 & 0.00 & 0.00 & 0.00 & 0.00 \\
\hline 18 & 0.00 & 0.00 & 0.00 & 0.00 & 0.00 & 0.00 & 0.00 & 0.00 & 0.00 & 0.00 & 0.00 & 0.00 \\
\hline 19 & 0.00 & 0.00 & 0.00 & 0.00 & 0.00 & 0.00 & 0.00 & 0.00 & 0.00 & 0.00 & 0.00 & 5.6 \\
\hline 20 & 0.00 & 0.00 & 0.00 & 0.00 & 0.00 & 0.00 & 0.00 & 0.00 & 0.00 & 0.05 & 5.5 & 0.00 \\
\hline 21 & 0.00 & 0.00 & 0.00 & 0.00 & 0.00 & 0.00 & 0.00 & 0.00 & 0.00 & 0.00 & 0.00 & 0.00 \\
\hline 22 & 0.00 & 0.00 & 0.00 & 0.00 & 0.00 & 0.00 & 0.00 & 0.00 & 0.00 & 0.00 & 0.00 & 0.00 \\
\hline 23 & 0.00 & 0.00 & 0.00 & 0.00 & 9.2 & 0.00 & 0.00 & 0.00 & 0.00 & 0.06 & 0.00 & 0.00 \\
\hline 24 & 0.00 & 0.00 & 0.00 & 0.00 & 1.8 & 0.00 & 0.00 & 0.00 & 0.00 & 1.2 & 0.00 & 0.00 \\
\hline 25 & 0.00 & 0.00 & 0.00 & 0.00 & 0.00 & 0.00 & 0.00 & 0.00 & 0.00 & 0.00 & 0.00 & 0.00 \\
\hline 26 & 0.00 & 0.00 & 0.00 & 0.00 & 0.00 & 0.00 & 0.00 & 0.00 & 0.00 & 0.00 & 0.00 & 0.00 \\
\hline 27 & 0.00 & 0.00 & 0.00 & 0.00 & 0.00 & 0.00 & 0.00 & 0.00 & 0.00 & 0.00 & 0.00 & 0.00 \\
\hline 28 & 0.00 & 0.00 & 0.00 & 0.00 & 3.1 & 0.00 & 0.00 & 0.00 & 0.00 & 0.00 & 0.00 & 0.00 \\
\hline 29 & 0.00 & 0.00 & 0.00 & 0.00 & 0.00 & 0.00 & 0.00 & 0.00 & 0.92 & 0.00 & 0.00 & 1.5 \\
\hline 30 & 0.00 & 0.00 & 0.00 & 0.00 & --- & 0.00 & 0.00 & 0.00 & 0.00 & 0.00 & 0.00 & 0.00 \\
\hline 31 & 0.00 & --- & 0.00 & 0.00 & --- & 0.00 & --- & 0.00 & --- & 0.00 & 0.00 & --- \\
\hline OTAL & 10.52 & 0.78 & 0.00 & 0.00 & 14.10 & 9.10 & 100.50 & 0.00 & 0.92 & 1.31 & 5.50 & 7.10 \\
\hline IEAN & 0.34 & 0.03 & 0.00 & 0.00 & 0.49 & 0.29 & 3.35 & 0.00 & 0.03 & 0.04 & 0.18 & 0.24 \\
\hline IAX & 9.9 & 0.74 & 0.00 & 0.00 & 9.2 & 6.7 & 49 & 0.00 & 0.92 & 1.2 & 5.5 & 5.6 \\
\hline IIN & 0.00 & 0.00 & 0.00 & 0.00 & 0.00 & 0.00 & 0.00 & 0.00 & 0.00 & 0.00 & 0.00 & 0.00 \\
\hline C-FT & 21 & 1.5 & 0.00 & 0.00 & 28 & 18 & 199 & 0.00 & 1.8 & 2.6 & 11 & 14 \\
\hline
\end{tabular}

STATISTICS OF MONTHLY MEAN DATA FOR WATER YEARS 2003 - 2004, BY WATER YEAR (WY)

\begin{tabular}{|c|c|c|c|c|c|c|c|c|c|c|c|c|}
\hline MEAN & 0.34 & 0.03 & 0.00 & 0.00 & 0.49 & 0.29 & 3.35 & 0.00 & 0.03 & 0.04 & 0.11 & 0.12 \\
\hline MAX & 0.34 & 0.03 & 0.00 & 0.00 & 0.49 & 0.29 & 3.35 & 0.00 & 0.03 & 0.04 & 0.18 & 0.24 \\
\hline (WY) & (2004) & (2004) & (2004) & (2004) & (2004) & (2004) & (2004) & (2004) & (2004) & (2004) & (2004) & (2004) \\
\hline MIN & 0.34 & 0.03 & 0.00 & 0.00 & 0.49 & 0.29 & 3.35 & 0.00 & 0.03 & 0.04 & 0.05 & 0.01 \\
\hline (WY) & (2004) & (2004) & (2004) & (2004) & (2004) & (2004) & (2004) & (2004) & (2004) & (2004) & (2003) & (2003) \\
\hline
\end{tabular}

SUMMARY STATISTICS

FOR 2004 WATER YEAR

WATER YEARS 2003 - 2004

ANNUAL TOTAL

ANNUAL MEAN

HIGHEST ANNUAL MEAN

LOWEST ANNUAL MEAN

HIGHEST DAILY MEAN

LOWEST DAILY MEAN

ANNUAL SEVEN-DAY MINIMUM

MAXIMUM PEAK FLOW

MAXIMUM PEAK STAGE

ANNUAL RUNOFF (AC-FT)

10 PERCENT EXCEEDS

50 PERCENT EXCEEDS

90 PERCENT EXCEEDS

$\begin{array}{ccc}149.83 & & \\ 0.41 & & \\ & & \\ 49 & \text { Apr } & 3 \\ 0.00 & \text { Oct } 1 \\ 0.00 & \text { Oct } 9 \\ 363 & \text { Aug 20 } \\ 1.09 & \text { Aug 20 } \\ 297 & & \\ 0.00 & & \\ 0.00 & & \\ 0.00 & & \end{array}$

$\begin{array}{crr}0.41 & \\ 0.41 & & 2004 \\ 0.41 & 2004 \\ 49 & \text { Apr } 3,2004 \\ 0.00 & \text { Jul 25, 2003 } \\ 0.00 & \text { Jul 25, 2003 } \\ 363 & \text { Aug 20, 2004 } \\ 1.09 & \text { Aug 20, 2004 } \\ 297 & \\ 0.00 & \\ 0.00 & \\ 0.00 & \end{array}$




\section{ARROYO 19A AT ALBUQUERQUE, NEW MEXICO}

\section{STATION ANALYSIS}

\section{WATER YEAR 2004}

Equipment.-- An electronic datalogger, recording on 5-minute intervals, is housed in a metal 15- by 15- by 18-inch shelter over a 12-inch diameter CMC stilling well attached to a 1foot Parshall flume. An outside staff gage is mounted to the flume for reference. The intake pipe to the well is 0.03 foot above the floor of the flume. Because the point of zero flow is 1.00 -foot, only flows above 1.03 feet $(0.035$ cubic feet per second) are recorded. A tipping-bucket rain gage is housed in a metal 15 - by 15 - by 18 -inch shelter over a 3 inch diameter galvanized pipe located approximately 40 feet south of the flume.

Gage-Height Record.-- The water-stage recorder supplied a complete and satisfactory record for water year 2004. The station was not operated during the winter period December 3, 2003, to March 3, 2004.

Rating.-- The control for the site is a 1-foot-wide Parshall flume, which is 1.2 feet tall and has a capacity of 5.28 cubic feet per second. In water year 1999, flows exceeded the capacity of the Parshall flume for the first time since the 1986 installation. The flume was submerged on two occasions; August 2 and August 5, 1999. Results of each slope-area indirect measurement are:

August 2, 1999, flood: Gage Height $=2.93$ feet $Q=235$ cubic feet per second August 5, 1999, flood: Gage Height $=2.63$ feet $Q=100$ cubic feet per second

Rating 1.0, used prior to water year 1999, did not extend beyond the flow capacity of the flume (5.28 cubic feet per second). Rating 2.0 was developed in 1999 and computes discharges up to 270 cubic feet per second. A breakpoint in the rating occurs at the gage height where the flume is filled to capacity ( 2.2 feet) and multiple offsets are used to plot the lower and upper portions of the stage-discharge relation.

No shifts are needed to rating 2.0 for water year 2004. The flume remains clear of debris or sediment. More high-water flows are needed to confirm the portion of rating 2.0 greater than the flume capacity.

During water year 2004, 11 no-flow visits were made at this site.

Discharge.-- Discharges are computed from rating 2.0 directly. Only one flow occurred in water year 2004. The maximum gage height and discharge were 1.08 feet and 0.11 cubic feet per second, respectively, on September 29. Flows at this site are rare and require a significant amount of rainfall in the upper watershed. 
RIO GRANDE BASIN

08329935 ARROYO 19A AT ALBUQUERQUE, NM

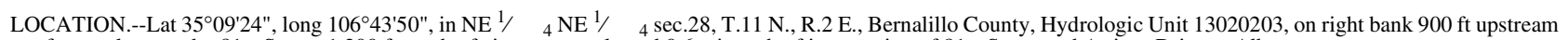
from culvert under 81 st Street, 1,200 ft south of city water tank, and $0.6 \mathrm{mi}$ south of intersection of 81st Street and Atrisco Drive at Albuquerque.

DRAINAGE AREA.-- $1.50 \mathrm{mi}^{2}$.

PERIOD OF RECORD.--June 1977 to current year (seasonal records).

GAGE.--Water-stage recorder and recording tipping-bucket rain gage with 0.01-in. increment. The control at the site is a Parshall flume. Elevation of gage is 5,341 $\mathrm{ft}$ above National Geodetic Vertical Datum of 1929, from topographic map. Prior to June 19, 1986, at site $450 \mathrm{ft}$ downstream at different datum.

REMARKS.--Records good. Recording rain gage at station. The basin drains undeveloped semidesert terrain above the escarpment west of Albuquerque. See tabulation below for monthly precipitation, in inches. No flow most of time.

EXTREMES FOR PERIOD OF RECORD.--Maximum discharge, $234 \mathrm{ft}^{3} / \mathrm{s}$, Aug. 2, 1999, gage height, $2.93 \mathrm{ft}$, on basis of 2 slope-area measurements of peak flow needed to extend rating beyond flume capacity. No flow most of time.

EXTREMES FOR CURRENT YEAR.--Only one flow in water year, discharge, $0.11 \mathrm{ft}^{3} / \mathrm{s}$, Sept. 29, gage height, $1.08 \mathrm{feet}$.

DISCHARGE, CUBIC FEET PER SECOND

WATER YEAR OCTOBER 2003 TO SEPTEMBER 2004

\begin{tabular}{|c|c|c|c|c|c|c|c|c|c|c|c|c|}
\hline DAY & OCT & NOV & DEC & JAN & FEB & MAR & APR & MAY & JUN & JUL & AUG & SEP \\
\hline $\begin{array}{l}1 \\
2 \\
3 \\
4 \\
5\end{array}$ & $\begin{array}{l}0.00 \\
0.00 \\
0.00 \\
0.00 \\
0.00\end{array}$ & $\begin{array}{l}0.00 \\
0.00 \\
0.00 \\
0.00 \\
0.00\end{array}$ & $\begin{array}{c}0.00 \\
0.00 \\
0.00 \\
--- \\
---\end{array}$ & $\begin{array}{l}--- \\
--- \\
--- \\
--- \\
---\end{array}$ & $\begin{array}{l}--- \\
--- \\
--- \\
--- \\
---\end{array}$ & $\begin{array}{c}--- \\
--- \\
0.00 \\
0.00 \\
0.00\end{array}$ & $\begin{array}{l}0.00 \\
0.00 \\
0.00 \\
0.00 \\
0.00\end{array}$ & $\begin{array}{l}0.00 \\
0.00 \\
0.00 \\
0.00 \\
0.00\end{array}$ & $\begin{array}{l}0.00 \\
0.00 \\
0.00 \\
0.00 \\
0.00\end{array}$ & $\begin{array}{l}0.00 \\
0.00 \\
0.00 \\
0.00 \\
0.00\end{array}$ & $\begin{array}{l}0.00 \\
0.00 \\
0.00 \\
0.00 \\
0.00\end{array}$ & $\begin{array}{l}0.00 \\
0.00 \\
0.00 \\
0.00 \\
0.00\end{array}$ \\
\hline $\begin{array}{r}6 \\
7 \\
8 \\
9 \\
10\end{array}$ & $\begin{array}{l}0.00 \\
0.00 \\
0.00 \\
0.00 \\
0.00\end{array}$ & $\begin{array}{l}0.00 \\
0.00 \\
0.00 \\
0.00 \\
0.00\end{array}$ & $\begin{array}{l}--- \\
--- \\
--- \\
--- \\
---\end{array}$ & $\begin{array}{l}--- \\
--- \\
-- \\
--- \\
---\end{array}$ & $\begin{array}{l}--- \\
--- \\
--- \\
--- \\
---\end{array}$ & $\begin{array}{l}0.00 \\
0.00 \\
0.00 \\
0.00 \\
0.00\end{array}$ & $\begin{array}{l}0.00 \\
0.00 \\
0.00 \\
0.00 \\
0.00\end{array}$ & $\begin{array}{l}0.00 \\
0.00 \\
0.00 \\
0.00 \\
0.00\end{array}$ & $\begin{array}{l}0.00 \\
0.00 \\
0.00 \\
0.00 \\
0.00\end{array}$ & $\begin{array}{l}0.00 \\
0.00 \\
0.00 \\
0.00 \\
0.00\end{array}$ & $\begin{array}{l}0.00 \\
0.00 \\
0.00 \\
0.00 \\
0.00\end{array}$ & $\begin{array}{l}0.00 \\
0.00 \\
0.00 \\
0.00 \\
0.00\end{array}$ \\
\hline $\begin{array}{l}11 \\
12 \\
13 \\
14 \\
15\end{array}$ & $\begin{array}{l}0.00 \\
0.00 \\
0.00 \\
0.00 \\
0.00\end{array}$ & $\begin{array}{l}0.00 \\
0.00 \\
0.00 \\
0.00 \\
0.00\end{array}$ & $\begin{array}{l}--- \\
--- \\
-- \\
--- \\
---\end{array}$ & $\begin{array}{l}--- \\
--- \\
--- \\
-- \\
--\end{array}$ & $\begin{array}{l}--- \\
--- \\
--- \\
--- \\
---\end{array}$ & $\begin{array}{l}0.00 \\
0.00 \\
0.00 \\
0.00 \\
0.00\end{array}$ & $\begin{array}{l}0.00 \\
0.00 \\
0.00 \\
0.00 \\
0.00\end{array}$ & $\begin{array}{l}0.00 \\
0.00 \\
0.00 \\
0.00 \\
0.00\end{array}$ & $\begin{array}{l}0.00 \\
0.00 \\
0.00 \\
0.00 \\
0.00\end{array}$ & $\begin{array}{l}0.00 \\
0.00 \\
0.00 \\
0.00 \\
0.00\end{array}$ & $\begin{array}{l}0.00 \\
0.00 \\
0.00 \\
0.00 \\
0.00\end{array}$ & $\begin{array}{l}0.00 \\
0.00 \\
0.00 \\
0.00 \\
0.00\end{array}$ \\
\hline $\begin{array}{l}16 \\
17 \\
18 \\
19 \\
20\end{array}$ & $\begin{array}{l}0.00 \\
0.00 \\
0.00 \\
0.00 \\
0.00\end{array}$ & $\begin{array}{l}0.00 \\
0.00 \\
0.00 \\
0.00 \\
0.00\end{array}$ & $\begin{array}{l}--- \\
--- \\
--- \\
--- \\
---\end{array}$ & $\begin{array}{l}--- \\
--- \\
--- \\
--- \\
---\end{array}$ & $\begin{array}{l}--- \\
--- \\
--- \\
--- \\
---\end{array}$ & $\begin{array}{l}0.00 \\
0.00 \\
0.00 \\
0.00 \\
0.00\end{array}$ & $\begin{array}{l}0.00 \\
0.00 \\
0.00 \\
0.00 \\
0.00\end{array}$ & $\begin{array}{l}0.00 \\
0.00 \\
0.00 \\
0.00 \\
0.00\end{array}$ & $\begin{array}{l}0.00 \\
0.00 \\
0.00 \\
0.00 \\
0.00\end{array}$ & $\begin{array}{l}0.00 \\
0.00 \\
0.00 \\
0.00 \\
0.00\end{array}$ & $\begin{array}{l}0.00 \\
0.00 \\
0.00 \\
0.00 \\
0.00\end{array}$ & $\begin{array}{l}0.00 \\
0.00 \\
0.00 \\
0.00 \\
0.00\end{array}$ \\
\hline $\begin{array}{l}21 \\
22 \\
23 \\
24 \\
25\end{array}$ & $\begin{array}{l}0.00 \\
0.00 \\
0.00 \\
0.00 \\
0.00\end{array}$ & $\begin{array}{l}0.00 \\
0.00 \\
0.00 \\
0.00 \\
0.00\end{array}$ & $\begin{array}{l}--- \\
--- \\
--- \\
--- \\
---\end{array}$ & $\begin{array}{l}--- \\
-- \\
-- \\
-- \\
--\end{array}$ & $\begin{array}{l}--- \\
--- \\
--- \\
--- \\
---\end{array}$ & $\begin{array}{l}0.00 \\
0.00 \\
0.00 \\
0.00 \\
0.00\end{array}$ & $\begin{array}{l}0.00 \\
0.00 \\
0.00 \\
0.00 \\
0.00\end{array}$ & $\begin{array}{l}0.00 \\
0.00 \\
0.00 \\
0.00 \\
0.00\end{array}$ & $\begin{array}{l}0.00 \\
0.00 \\
0.00 \\
0.00 \\
0.00\end{array}$ & $\begin{array}{l}0.00 \\
0.00 \\
0.00 \\
0.00 \\
0.00\end{array}$ & $\begin{array}{l}0.00 \\
0.00 \\
0.00 \\
0.00 \\
0.00\end{array}$ & $\begin{array}{l}0.00 \\
0.00 \\
0.00 \\
0.00 \\
0.00\end{array}$ \\
\hline $\begin{array}{l}26 \\
27 \\
28 \\
29 \\
30 \\
31\end{array}$ & $\begin{array}{l}0.00 \\
0.00 \\
0.00 \\
0.00 \\
0.00 \\
0.00\end{array}$ & $\begin{array}{l}0.00 \\
0.00 \\
0.00 \\
0.00 \\
0.00 \\
---\end{array}$ & $\begin{array}{l}--- \\
--- \\
--- \\
--- \\
--- \\
---\end{array}$ & $\begin{array}{l}--- \\
--- \\
-- \\
--- \\
--- \\
---\end{array}$ & $\begin{array}{l}--- \\
--- \\
--- \\
--- \\
--- \\
---\end{array}$ & $\begin{array}{l}0.00 \\
0.00 \\
0.00 \\
0.00 \\
0.00 \\
0.00\end{array}$ & $\begin{array}{c}0.00 \\
0.00 \\
0.00 \\
0.00 \\
0.00 \\
---\end{array}$ & $\begin{array}{l}0.00 \\
0.00 \\
0.00 \\
0.00 \\
0.00 \\
0.00\end{array}$ & $\begin{array}{c}0.00 \\
0.00 \\
0.00 \\
0.00 \\
0.00 \\
---\end{array}$ & $\begin{array}{l}0.00 \\
0.00 \\
0.00 \\
0.00 \\
0.00 \\
0.00\end{array}$ & $\begin{array}{l}0.00 \\
0.00 \\
0.00 \\
0.00 \\
0.00 \\
0.00\end{array}$ & $\begin{array}{c}0.00 \\
0.00 \\
0.00 \\
0.00 \\
0.00 \\
---\end{array}$ \\
\hline $\begin{array}{l}\text { OTAL } \\
\text { IEAN } \\
\text { IAX } \\
\text { IIN } \\
\text { C-FT } \\
- \text { ) }\end{array}$ & $\begin{array}{l}0.00 \\
0.00 \\
0.00 \\
0.00 \\
0.00 \\
1.16\end{array}$ & $\begin{array}{l}0.00 \\
0.00 \\
0.00 \\
0.00 \\
0.00 \\
0.75\end{array}$ & $\begin{array}{c}--- \\
--- \\
--- \\
--- \\
-- \\
0.14\end{array}$ & $\begin{array}{l}--- \\
--- \\
--- \\
--- \\
--- \\
0.16\end{array}$ & $\begin{array}{l}--- \\
--- \\
--- \\
--- \\
--- \\
1.22\end{array}$ & $\begin{array}{l}--- \\
--- \\
--- \\
--- \\
--- \\
0.92\end{array}$ & $\begin{array}{l}0.00 \\
0.00 \\
0.00 \\
0.00 \\
0.00 \\
2.81\end{array}$ & $\begin{array}{l}0.00 \\
0.00 \\
0.00 \\
0.00 \\
0.00 \\
0.00\end{array}$ & $\begin{array}{l}0.00 \\
0.00 \\
0.00 \\
0.00 \\
0.00 \\
0.58\end{array}$ & $\begin{array}{l}0.00 \\
0.00 \\
0.00 \\
0.00 \\
0.00 \\
1.66\end{array}$ & $\begin{array}{l}0.00 \\
0.00 \\
0.00 \\
0.00 \\
0.00 \\
0.23\end{array}$ & $\begin{array}{l}0.00 \\
0.00 \\
0.00 \\
0.00 \\
0.00 \\
1.39\end{array}$ \\
\hline
\end{tabular}

(+) Total precipitation accumulation, in inches. 


\section{MARIPOSA DIVERSION OF SAN ANTONIO ARROYO AT ALBUQUERQUE, NEW MEXICO}

\section{STATION ANALYSIS}

\section{WATER YEAR 2004}

Equipment.-- This station was established during the summer of 1993 exclusively for waterquality sampling. As desired of the cooperators, AMAFCA and City of Albuquerque Hydrology Department, only gage heights during sampling were recorded. No data for this site were published in the USGS Annual Water-Data Report prior to water year 2001. Complete water year discharge records were not calculated until water year 2000. On October 26, 1999, an electronic datalogger and pressure transducer became the primary water-stage recorder. The instruments are housed in a metal 2.5 - by 2.5 - by 6 -foot shelter anchored to a concrete pad on the left bank, approximately 15 feet upstream from a 15foot-diameter corrugated metal culvert. The culvert acts as the gage control. An outside staff with attached crest-stage gage is mounted approximately 10 feet upstream from the culvert. The pressure transducer orifice is mounted to the concrete pad immediately upstream from the culvert. The point of zero flow is a chiseled square on the concrete pad of the culvert entrance. Its given elevation is 1.00 foot.

Gage-Height Record.-- The recorder referenced to the outside staff gave a complete and satisfactory record during the entire water year, except September 19 to October 7, 2004, when the recorder malfunctioned. During this time period, flows occurred only on September 19-20 and 29-30 because no flows occur without a significant precipitation event in the watershed. The daily mean discharges for these four days were estimated based on rainfall in the basin and good peak gage heights recorded by the Sutron on September 19 and by field personnel during a water-quality sampling event on September 29. The sensor orifice is mounted in a depression upstream from the culvert lip, so all flow depths above the point of zero flow (PZF) are recorded.

Rating.-- The concrete lip at the culvert entrance acts as the low-flow control and PZF. Low flows are measured with a standard current-velocity meter and higher flows are calculated indirectly using culvert-flow computational methods. Rating 3.0 was in effect prior to water year 2001 and has a PZF of 0.00 foot. To avoid negative gage height readings during times of no flow, the recorders are set with a built-in 1.00-foot datum, or an effective PZF of 1.00 foot. Rating 4.0, which incorporates this 1.00-foot datum, was developed and started in water year 2001. The new rating is the same as rating 3.0 in all other aspects.

Discharge.-- Rating 4.0 was applied directly without shifts this water year. Rating shifts may be required if debris accumulates in the barrel or entrance of the culvert. Estimated discharges are based exclusively on precipitation records for the watershed, because no upstream or downstream gages are available for comparison purposes. The peak stage and discharge for this water year occurred on April 3, 2004, and were 2.67 feet and 51 cubic feet per second, respectively. Twenty no-flow inspections were made and 2 waterquality samples were taken at this site in water year 2004. 
RIO GRANDE BASIN

083299375 MARIPOSA DIVERSION OF SAN ANTONIO ARROYO AT ALBUQUERQUE

LOCATION.--Lat 3508'24", long 106 42' 17", in SE $1 /{ }_{4}$ NE $1 /{ }_{4}$ of sec.35, T.11 N., R.2 E., Bernalillo County, Hydrologic Unit 13020203, 1,500 ft upstream from the San Antonio underpass at Coors Blvd. on west side of Albuquerque, 1.1 mi north of Interstate 25 and Coors Blvd. intersection.

DRAINAGE AREA.--30.5 $\mathrm{mi}^{2}$.

PERIOD OF RECORD.--Summer 1993 to September 1999 (only recorded flow events during water-quality sampling). October 1999 to current year.

GAGE.--Water-stage recorder and crest-stage gage referenced to outside staff gage. Elevation of gage is 5,100 ft above the National Geodetic Vertical Datum of 1929, from topographic map.

REMARKS.--Records good except for those estimated, which are poor. No flows will occur unless significant precipitation falls in the watershed.

DISCHARGE, CUBIC FEET PER SECOND

WATER YEAR OCTOBER 2003 TO SEPTEMBER 2004

\begin{tabular}{|c|c|c|c|c|c|c|c|c|c|c|c|c|}
\hline DAY & OCT & $\mathrm{NOV}$ & DEC & JAN & FEB & MAR & APR & MAY & JUN & JUL & AUG & SEP \\
\hline $\begin{array}{l}1 \\
2 \\
3 \\
4 \\
5\end{array}$ & $\begin{array}{l}0.00 \\
0.00 \\
0.00 \\
0.00 \\
0.00\end{array}$ & $\begin{array}{l}0.00 \\
0.00 \\
0.00 \\
0.00 \\
0.00\end{array}$ & $\begin{array}{l}0.00 \\
0.00 \\
0.00 \\
0.00 \\
0.00\end{array}$ & $\begin{array}{l}0.00 \\
0.00 \\
0.00 \\
0.00 \\
0.00\end{array}$ & $\begin{array}{l}0.00 \\
0.00 \\
0.00 \\
0.00 \\
0.00\end{array}$ & $\begin{array}{l}0.00 \\
0.00 \\
0.11 \\
5.4 \\
0.45\end{array}$ & $\begin{array}{l}0.00 \\
1.4 \\
19 \\
4.6 \\
0.21\end{array}$ & $\begin{array}{l}0.00 \\
0.00 \\
0.00 \\
0.00 \\
0.00\end{array}$ & $\begin{array}{l}0.00 \\
0.00 \\
0.00 \\
0.00 \\
0.00\end{array}$ & $\begin{array}{l}0.00 \\
0.00 \\
0.00 \\
0.00 \\
0.00\end{array}$ & $\begin{array}{l}0.00 \\
0.00 \\
0.00 \\
0.00 \\
0.00\end{array}$ & $\begin{array}{l}0.00 \\
0.00 \\
0.00 \\
0.00 \\
0.00\end{array}$ \\
\hline $\begin{array}{r}6 \\
7 \\
8 \\
9 \\
10\end{array}$ & $\begin{array}{l}0.00 \\
4.9 \\
2.2 \\
0.09 \\
0.00\end{array}$ & $\begin{array}{l}0.00 \\
0.00 \\
0.00 \\
0.00 \\
0.00\end{array}$ & $\begin{array}{l}0.00 \\
0.00 \\
0.00 \\
0.00 \\
0.00\end{array}$ & $\begin{array}{l}0.00 \\
0.00 \\
0.00 \\
0.00 \\
0.00\end{array}$ & $\begin{array}{l}0.00 \\
0.00 \\
0.00 \\
0.00 \\
0.00\end{array}$ & $\begin{array}{l}0.00 \\
0.00 \\
0.00 \\
0.00 \\
0.00\end{array}$ & $\begin{array}{l}0.00 \\
0.00 \\
1.4 \\
0.25 \\
0.99\end{array}$ & $\begin{array}{l}0.00 \\
0.00 \\
0.00 \\
0.00 \\
0.00\end{array}$ & $\begin{array}{l}0.00 \\
0.00 \\
0.00 \\
0.00 \\
0.00\end{array}$ & $\begin{array}{l}0.00 \\
0.00 \\
0.00 \\
0.00 \\
0.00\end{array}$ & $\begin{array}{l}0.00 \\
0.00 \\
0.00 \\
0.00 \\
0.00\end{array}$ & $\begin{array}{l}0.00 \\
0.00 \\
0.00 \\
0.00 \\
0.00\end{array}$ \\
\hline $\begin{array}{l}11 \\
12 \\
13 \\
14 \\
15\end{array}$ & $\begin{array}{l}0.00 \\
0.00 \\
0.00 \\
0.00 \\
0.00\end{array}$ & $\begin{array}{l}0.00 \\
0.36 \\
1.5 \\
0.03 \\
0.00\end{array}$ & $\begin{array}{l}0.00 \\
0.00 \\
0.00 \\
0.00 \\
0.00\end{array}$ & $\begin{array}{l}0.00 \\
0.00 \\
0.00 \\
0.00 \\
0.00\end{array}$ & $\begin{array}{l}0.00 \\
0.00 \\
0.00 \\
0.00 \\
0.00\end{array}$ & $\begin{array}{l}0.00 \\
0.00 \\
0.00 \\
0.00 \\
0.00\end{array}$ & $\begin{array}{l}1.1 \\
0.01 \\
0.00 \\
0.00 \\
0.00\end{array}$ & $\begin{array}{l}0.00 \\
0.00 \\
0.00 \\
0.00 \\
0.00\end{array}$ & $\begin{array}{l}0.00 \\
0.00 \\
0.00 \\
0.00 \\
0.00\end{array}$ & $\begin{array}{l}0.00 \\
0.00 \\
0.00 \\
0.00 \\
0.00\end{array}$ & $\begin{array}{l}0.00 \\
0.00 \\
0.00 \\
0.00 \\
0.00\end{array}$ & $\begin{array}{l}0.00 \\
0.00 \\
0.00 \\
0.00 \\
0.00\end{array}$ \\
\hline $\begin{array}{l}16 \\
17 \\
18 \\
19 \\
20\end{array}$ & $\begin{array}{l}0.00 \\
0.00 \\
0.00 \\
0.00 \\
0.00\end{array}$ & $\begin{array}{l}0.00 \\
0.00 \\
0.00 \\
0.00 \\
0.00\end{array}$ & $\begin{array}{l}0.00 \\
0.00 \\
0.00 \\
0.00 \\
0.00\end{array}$ & $\begin{array}{l}0.00 \\
0.00 \\
0.00 \\
0.00 \\
0.00\end{array}$ & $\begin{array}{l}0.00 \\
0.00 \\
0.00 \\
0.00 \\
0.00\end{array}$ & $\begin{array}{l}0.00 \\
0.00 \\
0.00 \\
0.00 \\
0.00\end{array}$ & $\begin{array}{l}0.00 \\
0.00 \\
0.00 \\
0.00 \\
0.00\end{array}$ & $\begin{array}{l}0.00 \\
0.00 \\
0.00 \\
0.00 \\
0.00\end{array}$ & $\begin{array}{l}0.00 \\
0.00 \\
0.00 \\
0.00 \\
0.00\end{array}$ & $\begin{array}{l}0.00 \\
0.00 \\
0.00 \\
0.00 \\
0.00\end{array}$ & $\begin{array}{l}0.00 \\
0.00 \\
0.00 \\
0.00 \\
0.00\end{array}$ & $\begin{array}{c}0.00 \\
0.00 \\
0.00 \\
\mathrm{e} 1.4 \\
\mathrm{e} 0.00\end{array}$ \\
\hline $\begin{array}{l}21 \\
22 \\
23 \\
24 \\
25\end{array}$ & $\begin{array}{l}0.00 \\
0.00 \\
0.00 \\
0.00 \\
0.00\end{array}$ & $\begin{array}{l}0.00 \\
0.00 \\
0.00 \\
0.00 \\
0.00\end{array}$ & $\begin{array}{l}0.00 \\
0.00 \\
0.00 \\
0.00 \\
0.00\end{array}$ & $\begin{array}{l}0.00 \\
0.00 \\
0.00 \\
0.00 \\
0.00\end{array}$ & $\begin{array}{l}0.00 \\
0.00 \\
2.7 \\
4.8 \\
0.05\end{array}$ & $\begin{array}{l}0.00 \\
0.00 \\
0.00 \\
0.00 \\
0.00\end{array}$ & $\begin{array}{l}0.00 \\
0.00 \\
0.00 \\
0.00 \\
0.00\end{array}$ & $\begin{array}{l}0.00 \\
0.00 \\
0.00 \\
0.00 \\
0.00\end{array}$ & $\begin{array}{l}0.00 \\
0.00 \\
0.00 \\
0.00 \\
0.00\end{array}$ & $\begin{array}{l}0.07 \\
1.9 \\
0.65 \\
0.08 \\
3.2\end{array}$ & $\begin{array}{l}0.00 \\
0.00 \\
0.00 \\
0.00 \\
0.00\end{array}$ & $\begin{array}{l}0.00 \\
0.00 \\
0.00 \\
0.00 \\
0.00\end{array}$ \\
\hline $\begin{array}{l}26 \\
27 \\
28 \\
29 \\
30 \\
31\end{array}$ & $\begin{array}{l}0.00 \\
0.00 \\
0.00 \\
0.00 \\
0.00 \\
0.00\end{array}$ & $\begin{array}{l}0.00 \\
0.00 \\
0.00 \\
0.00 \\
0.00 \\
---\end{array}$ & $\begin{array}{l}0.00 \\
0.00 \\
0.00 \\
0.00 \\
0.00 \\
0.00\end{array}$ & $\begin{array}{l}0.00 \\
0.00 \\
0.00 \\
0.00 \\
0.00 \\
0.00\end{array}$ & $\begin{array}{l}0.00 \\
0.00 \\
0.00 \\
0.00 \\
--- \\
---\end{array}$ & $\begin{array}{l}0.00 \\
0.00 \\
0.00 \\
0.00 \\
0.00 \\
0.00\end{array}$ & $\begin{array}{l}0.00 \\
0.00 \\
0.00 \\
0.00 \\
0.00 \\
---\end{array}$ & $\begin{array}{l}0.00 \\
0.00 \\
0.00 \\
0.00 \\
0.00 \\
0.00\end{array}$ & $\begin{array}{l}0.00 \\
0.00 \\
0.00 \\
2.3 \\
0.01 \\
---\end{array}$ & $\begin{array}{l}0.02 \\
0.00 \\
0.00 \\
0.00 \\
0.00 \\
0.00\end{array}$ & $\begin{array}{l}0.00 \\
0.00 \\
0.00 \\
0.00 \\
0.00 \\
0.00\end{array}$ & $\begin{array}{r}0.00 \\
0.00 \\
0.00 \\
\mathrm{e} 3.9 \\
\mathrm{e} 1.6 \\
---\end{array}$ \\
\hline $\begin{array}{l}\text { OTAL } \\
\text { IEAN } \\
\text { IAX } \\
\text { IIN } \\
\text { C-FT }\end{array}$ & $\begin{array}{l}7.19 \\
0.23 \\
4.9 \\
0.00 \\
14\end{array}$ & $\begin{array}{l}1.89 \\
0.06 \\
1.5 \\
0.00 \\
3.7\end{array}$ & $\begin{array}{l}0.00 \\
0.00 \\
0.00 \\
0.00 \\
0.00\end{array}$ & $\begin{array}{l}0.00 \\
0.00 \\
0.00 \\
0.00 \\
0.00\end{array}$ & $\begin{array}{c}7.55 \\
0.26 \\
4.8 \\
0.00 \\
15\end{array}$ & $\begin{array}{l}5.96 \\
0.19 \\
5.4 \\
0.00 \\
12\end{array}$ & $\begin{array}{c}28.96 \\
0.97 \\
19 \\
0.00 \\
57\end{array}$ & $\begin{array}{l}0.00 \\
0.00 \\
0.00 \\
0.00 \\
0.00\end{array}$ & $\begin{array}{l}2.31 \\
0.08 \\
2.3 \\
0.00 \\
4.6\end{array}$ & $\begin{array}{c}5.92 \\
0.19 \\
3.2 \\
0.00 \\
12\end{array}$ & $\begin{array}{l}0.00 \\
0.00 \\
0.00 \\
0.00 \\
0.00\end{array}$ & $\begin{array}{l}6.90 \\
0.23 \\
3.9 \\
0.00 \\
14\end{array}$ \\
\hline
\end{tabular}

STATISTICS OF MONTHLY MEAN DATA FOR WATER YEARS 2000 - 2004, BY WATER YEAR (WY)

\begin{tabular}{|c|c|c|c|c|c|c|c|c|c|c|c|c|}
\hline MEAN & 0.22 & 0.07 & 0.01 & 0.01 & 0.05 & 0.15 & 0.20 & 0.00 & 0.08 & 0.09 & 0.14 & 0.13 \\
\hline MAX & 0.55 & 0.25 & 0.03 & 0.03 & 0.26 & 0.28 & 0.97 & 0.01 & 0.30 & 0.19 & 0.36 & 0.42 \\
\hline (WY) & (2001) & (2001) & (2003) & (2001) & (2004) & (2003) & (2004) & (2001) & (2000) & (2004) & (2002) & $(2002)$ \\
\hline MIN & 0.00 & 0.00 & 0.00 & 0.00 & 0.00 & 0.00 & 0.00 & 0.00 & 0.00 & 0.00 & 0.00 & 0.00 \\
\hline (WY) & (2002) & (2000) & (2002) & (2000) & (2000) & (2002) & (2002) & (2000) & (2001) & (2002) & (2004) & (2000) \\
\hline
\end{tabular}

SUMMARY STATISTICS

FOR 2003 CALENDAR YEAR

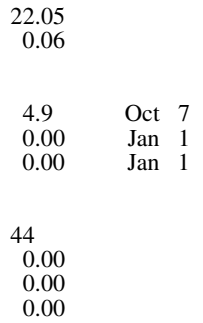

FOR 2004 WATER YEAR

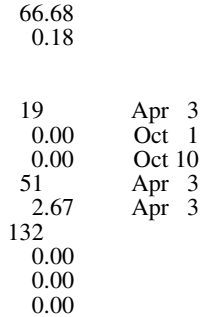

WATER YEARS 2000 - 2004

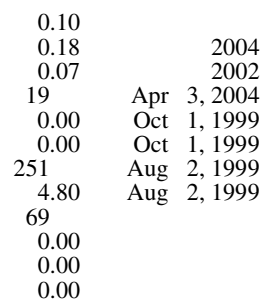

e Estimated 


\section{LADERA ARROYO AT ALBUQUERQUE, NEW MEXICO}

\section{STATION ANALYSIS}

\section{WATER YEAR 2004}

Equipment.-- An electronic datalogger, recording on 5-minute intervals, is housed in a metal shelter over an 18-inch-diameter corrugated metal stilling well. Inside and outside staff gages are available as references. An electric-tape gage was installed as an additional inside reference gage on September 12,2000. A peak stage indicator clip was attached to the float tape on April 23,1998. A tipping-bucket rain gage is housed in a metal 15by 15 - by 18 -inch shelter attached to a 3-inch-diameter galvanized pipe and is located approximately 75 feet south of the water-stage recorder.

Gage-Height Record.-- The water-stage recorder referenced to the inside staff and electric-tape gage gave a complete and satisfactory record for the entire water year. This station was not operated during the winter period from December 3, 2003, to March 3, 2004.

Rating.--The channel is straight for approximately 40 feet upstream and 300 feet downstream from the gage. The channel bottom is plane-bedded, loose sand and is approximately 1520 feet wide with no vegetation. Light to moderate vegetation exists on both banks, mostly small weeds and shrubs. An occasional desert willow shrub grows on the right overbank area. Both banks are generally less than 2 feet high and contain most flows.

Rating 5.0 was developed in water year 1999 and was based on the 4 measurements completed during that year. Measurements 5 and 6 , along with the approximate PZF for most of that water year (2.20 feet) defined the lower end of the new rating and the two slope-area indirect measurements ( 4 and 7 ) defined the upper end. The rating breaks to the right at about the 3.3- to 3.4-foot gage height range because this represents the level when flows start to top the channel banks and spill over to a flatter, wider flood plain.

The channel bottom (PZF) was at approximately 2.00 feet on the outside staff at the close of water year 2001 and because the PZF for rating 5.0 is 2.20 feet, a +0.20 shift to the rating is required. No flows occurred in water years 2002-03, so the same +0.20 -foot shift effective at the close of water year 2001 was carried through water years 2002 and 2003. Only one flow occurred in water year 2004, on July $24-25$. The +.20 -foot shift was continued up until that time. The channel bottom (PZF) was approximately 2.00 feet on the outside staff prior to July 24, 2004. After the flow of July 24-25, 2004, the channel bottom aggraded to a level of 2.25 feet ( $+/-0.10$ feet), which indicates a shift of approximately zero to rating 5.0. Because the field measurement of PZF, or channel bottom elevation, is only an approximation to within the nearest 0.10 feet, a zero shift was applied for the remainder of water year 2004. This shift diagram was derived from 3 points of reference; the low end point is, obviously, below the PZF; the mid point (3.4 feet) represents the break in the rating where flows begin to overtop the small banks and spill out onto a broader flood plain; and the upper input point represents the top of the rating, which was defined by the water year 1999 flood event. The shift value is held constant through the mid-point break of 3.4 feet because a change in bed elevation affects all flows within the confines of the small banks. The shift value returns to zero by the top of the rating, at a gage height of 4.1 feet. 
Discharge.-- During water year 2004, 11 no-flow site visits were made. Only one flow occurred this water year, on July 24-25. The maximum gage height and discharge for the water year was 2.43 feet and 4.8 cubic feet per second, respectively, on July 25. Because of its flashy nature, with flows lasting less than an hour, actually observing any flow is difficult. Usually, only points of zero flow (channel bottom elevations) are available to define shifts. This channel does not flow until significant thunderstorms occur in the watershed. 
RIO GRANDE BASIN

08329938 LADERA ARROYO AT ALBUQUERQUE, NM

LOCATION.--Lat 35 $06^{\prime} 56^{\prime \prime}$, long $106^{\circ} 44^{\prime} 48^{\prime \prime}$, in Town of Atrisco Land Grant, Bernalillo County, Hydrologic Unit 13020203, on left bank, 0.25 mi northwest of City of Albuquerque water storage tank, on dirt road extension of 98th Street, and 2.3 mi west of North Coors Road in Albuquerque.

DRAINAGE AREA.--0.34 $\mathrm{mi}^{2}$.

PERIOD OF RECORD.--May 1981 to current year (seasonal records).

GAGE.--Water-stage recorder and recording tipping-bucket rain gage with 0.01-in. increment. Elevation of gage is 5,312 ft above National Geodetic Vertical Datum of 1929, from topographic map. Prior to June 5, 1986, at site 0.2 mi downstream at different datum.

REMARKS.--Records fair. Recording rain gage at station. The basin is undeveloped semidesert terrain, part of which is above the escarpment west of Albuquerque. See tabulation below for monthly precipitation in inches.

EXTREMES FOR PERIOD OF RECORD.--Maximum discharge, $195 \mathrm{ft}^{3} / \mathrm{s}$, Aug. 2, 1999, gage height, $4.12 \mathrm{ft}$, from slope-area indirect measurement; no flow most of time.

EXTREMES FOR CURRENT YEAR.--Only one flow this water year. Maximum discharge, $4.8 \mathrm{ft}^{3} / \mathrm{s}$, July 25 , gage height, $2.43 \mathrm{ft}$; no flow most of time.

DISCHARGE, CUBIC FEET PER SECOND

WATER YEAR OCTOBER 2003 TO SEPTEMBER 2004

\begin{tabular}{|c|c|c|c|c|c|c|c|c|c|c|c|c|}
\hline DAY & OCT & NOV & DEC & JAN & FEB & MAR & APR & MAY & JUN & JUL & AUG & SEP \\
\hline $\begin{array}{l}1 \\
2 \\
3 \\
4 \\
5\end{array}$ & $\begin{array}{l}0.00 \\
0.00 \\
0.00 \\
0.00 \\
0.00\end{array}$ & $\begin{array}{l}0.00 \\
0.00 \\
0.00 \\
0.00 \\
0.00\end{array}$ & $\begin{array}{c}0.00 \\
0.00 \\
0.00 \\
--- \\
---\end{array}$ & $\begin{array}{l}--- \\
--- \\
--- \\
--- \\
---\end{array}$ & $\begin{array}{l}--- \\
--- \\
--- \\
--- \\
---\end{array}$ & $\begin{array}{c}--- \\
--- \\
0.00 \\
0.00 \\
0.00\end{array}$ & $\begin{array}{l}0.00 \\
0.00 \\
0.00 \\
0.00 \\
0.00\end{array}$ & $\begin{array}{l}0.00 \\
0.00 \\
0.00 \\
0.00 \\
0.00\end{array}$ & $\begin{array}{l}0.00 \\
0.00 \\
0.00 \\
0.00 \\
0.00\end{array}$ & $\begin{array}{l}0.00 \\
0.00 \\
0.00 \\
0.00 \\
0.00\end{array}$ & $\begin{array}{l}0.00 \\
0.00 \\
0.00 \\
0.00 \\
0.00\end{array}$ & $\begin{array}{l}0.00 \\
0.00 \\
0.00 \\
0.00 \\
0.00\end{array}$ \\
\hline $\begin{array}{r}6 \\
7 \\
8 \\
9 \\
10\end{array}$ & $\begin{array}{l}0.00 \\
0.00 \\
0.00 \\
0.00 \\
0.00\end{array}$ & $\begin{array}{l}0.00 \\
0.00 \\
0.00 \\
0.00 \\
0.00\end{array}$ & $\begin{array}{l}-- \\
--- \\
--- \\
-- \\
---\end{array}$ & $\begin{array}{l}--- \\
--- \\
--- \\
--- \\
---\end{array}$ & $\begin{array}{l}--- \\
--- \\
--- \\
--- \\
---\end{array}$ & $\begin{array}{l}0.00 \\
0.00 \\
0.00 \\
0.00 \\
0.00\end{array}$ & $\begin{array}{l}0.00 \\
0.00 \\
0.00 \\
0.00 \\
0.00\end{array}$ & $\begin{array}{l}0.00 \\
0.00 \\
0.00 \\
0.00 \\
0.00\end{array}$ & $\begin{array}{l}0.00 \\
0.00 \\
0.00 \\
0.00 \\
0.00\end{array}$ & $\begin{array}{l}0.00 \\
0.00 \\
0.00 \\
0.00 \\
0.00\end{array}$ & $\begin{array}{l}0.00 \\
0.00 \\
0.00 \\
0.00 \\
0.00\end{array}$ & $\begin{array}{l}0.00 \\
0.00 \\
0.00 \\
0.00 \\
0.00\end{array}$ \\
\hline $\begin{array}{l}11 \\
12 \\
13 \\
14 \\
15\end{array}$ & $\begin{array}{l}0.00 \\
0.00 \\
0.00 \\
0.00 \\
0.00\end{array}$ & $\begin{array}{l}0.00 \\
0.00 \\
0.00 \\
0.00 \\
0.00\end{array}$ & $\begin{array}{l}--- \\
--- \\
--- \\
--- \\
---\end{array}$ & $\begin{array}{l}--- \\
--- \\
--- \\
--- \\
---\end{array}$ & $\begin{array}{l}--- \\
--- \\
--- \\
--- \\
---\end{array}$ & $\begin{array}{l}0.00 \\
0.00 \\
0.00 \\
0.00 \\
0.00\end{array}$ & $\begin{array}{l}0.00 \\
0.00 \\
0.00 \\
0.00 \\
0.00\end{array}$ & $\begin{array}{l}0.00 \\
0.00 \\
0.00 \\
0.00 \\
0.00\end{array}$ & $\begin{array}{l}0.00 \\
0.00 \\
0.00 \\
0.00 \\
0.00\end{array}$ & $\begin{array}{l}0.00 \\
0.00 \\
0.00 \\
0.00 \\
0.00\end{array}$ & $\begin{array}{l}0.00 \\
0.00 \\
0.00 \\
0.00 \\
0.00\end{array}$ & $\begin{array}{l}0.00 \\
0.00 \\
0.00 \\
0.00 \\
0.00\end{array}$ \\
\hline $\begin{array}{l}16 \\
17 \\
18 \\
19 \\
20\end{array}$ & $\begin{array}{l}0.00 \\
0.00 \\
0.00 \\
0.00 \\
0.00\end{array}$ & $\begin{array}{l}0.00 \\
0.00 \\
0.00 \\
0.00 \\
0.00\end{array}$ & $\begin{array}{l}--- \\
--- \\
--- \\
---\end{array}$ & $\begin{array}{l}--- \\
--- \\
--- \\
--- \\
---\end{array}$ & $\begin{array}{l}--- \\
--- \\
--- \\
--- \\
---\end{array}$ & $\begin{array}{l}0.00 \\
0.00 \\
0.00 \\
0.00 \\
0.00\end{array}$ & $\begin{array}{l}0.00 \\
0.00 \\
0.00 \\
0.00 \\
0.00\end{array}$ & $\begin{array}{l}0.00 \\
0.00 \\
0.00 \\
0.00 \\
0.00\end{array}$ & $\begin{array}{l}0.00 \\
0.00 \\
0.00 \\
0.00 \\
0.00\end{array}$ & $\begin{array}{l}0.00 \\
0.00 \\
0.00 \\
0.00 \\
0.00\end{array}$ & $\begin{array}{l}0.00 \\
0.00 \\
0.00 \\
0.00 \\
0.00\end{array}$ & $\begin{array}{l}0.00 \\
0.00 \\
0.00 \\
0.00 \\
0.00\end{array}$ \\
\hline $\begin{array}{l}21 \\
22 \\
23 \\
24 \\
25\end{array}$ & $\begin{array}{l}0.00 \\
0.00 \\
0.00 \\
0.00 \\
0.00\end{array}$ & $\begin{array}{l}0.00 \\
0.00 \\
0.00 \\
0.00 \\
0.00\end{array}$ & $\begin{array}{l}--- \\
--- \\
-- \\
-- \\
---\end{array}$ & $\begin{array}{l}--- \\
--- \\
--- \\
--- \\
---\end{array}$ & $\begin{array}{l}--- \\
--- \\
--- \\
--- \\
---\end{array}$ & $\begin{array}{l}0.00 \\
0.00 \\
0.00 \\
0.00 \\
0.00\end{array}$ & $\begin{array}{l}0.00 \\
0.00 \\
0.00 \\
0.00 \\
0.00\end{array}$ & $\begin{array}{l}0.00 \\
0.00 \\
0.00 \\
0.00 \\
0.00\end{array}$ & $\begin{array}{l}0.00 \\
0.00 \\
0.00 \\
0.00 \\
0.00\end{array}$ & $\begin{array}{l}0.00 \\
0.00 \\
0.00 \\
0.02 \\
0.08\end{array}$ & $\begin{array}{l}0.00 \\
0.00 \\
0.00 \\
0.00 \\
0.00\end{array}$ & $\begin{array}{l}0.00 \\
0.00 \\
0.00 \\
0.00 \\
0.00\end{array}$ \\
\hline $\begin{array}{l}26 \\
27 \\
28 \\
29 \\
30 \\
31\end{array}$ & $\begin{array}{l}0.00 \\
0.00 \\
0.00 \\
0.00 \\
0.00 \\
0.00\end{array}$ & $\begin{array}{l}0.00 \\
0.00 \\
0.00 \\
0.00 \\
0.00 \\
---\end{array}$ & $\begin{array}{l}--- \\
--- \\
--- \\
--- \\
--- \\
---\end{array}$ & $\begin{array}{l}--- \\
--- \\
--- \\
--- \\
--- \\
---\end{array}$ & $\begin{array}{l}--- \\
--- \\
--- \\
--- \\
--- \\
---\end{array}$ & $\begin{array}{l}0.00 \\
0.00 \\
0.00 \\
0.00 \\
0.00 \\
0.00\end{array}$ & $\begin{array}{c}0.00 \\
0.00 \\
0.00 \\
0.00 \\
0.00 \\
---\end{array}$ & $\begin{array}{l}0.00 \\
0.00 \\
0.00 \\
0.00 \\
0.00 \\
0.00\end{array}$ & $\begin{array}{l}0.00 \\
0.00 \\
0.00 \\
0.00 \\
0.00 \\
---\end{array}$ & $\begin{array}{l}0.00 \\
0.00 \\
0.00 \\
0.00 \\
0.00 \\
0.00\end{array}$ & $\begin{array}{l}0.00 \\
0.00 \\
0.00 \\
0.00 \\
0.00 \\
0.00\end{array}$ & $\begin{array}{c}0.00 \\
0.00 \\
0.00 \\
0.00 \\
0.00 \\
---\end{array}$ \\
\hline $\begin{array}{l}\text { TOTAL } \\
\text { MEAN } \\
\text { MAX } \\
\text { MIN } \\
\text { AC-FT } \\
(+)\end{array}$ & $\begin{array}{l}0.00 \\
0.00 \\
0.00 \\
0.00 \\
0.00 \\
1.03\end{array}$ & $\begin{array}{l}0.00 \\
0.00 \\
0.00 \\
0.00 \\
0.00 \\
0.84\end{array}$ & $\begin{array}{l}--- \\
--- \\
--- \\
--- \\
--- \\
0.27\end{array}$ & $\begin{array}{l}--- \\
--- \\
--- \\
--- \\
--- \\
0.26\end{array}$ & $\begin{array}{c}--- \\
--- \\
--- \\
--- \\
--- \\
1.69\end{array}$ & $\begin{array}{c}--- \\
--- \\
--- \\
--- \\
-- \\
1.60\end{array}$ & $\begin{array}{l}0.00 \\
0.00 \\
0.00 \\
0.00 \\
0.00 \\
3.58\end{array}$ & $\begin{array}{l}0.00 \\
0.00 \\
0.00 \\
0.00 \\
0.00 \\
0.03\end{array}$ & $\begin{array}{l}0.00 \\
0.00 \\
0.00 \\
0.00 \\
0.00 \\
0.22\end{array}$ & $\begin{array}{l}0.10 \\
0.00 \\
0.08 \\
0.00 \\
0.2 \\
1.36\end{array}$ & $\begin{array}{l}0.00 \\
0.00 \\
0.00 \\
0.00 \\
0.00 \\
0.17\end{array}$ & $\begin{array}{l}0.00 \\
0.00 \\
0.00 \\
0.00 \\
0.00 \\
0.73\end{array}$ \\
\hline \multicolumn{13}{|c|}{ STATISTICS OF MONTHLY MEAN DATA FOR WATER YEARS 1981 - 2004, BY WATER YEAR (WY) } \\
\hline $\begin{array}{l}\text { MEAN } \\
\text { MAX } \\
\text { (WY) } \\
\text { MIN } \\
\text { (WY) }\end{array}$ & $\begin{array}{r}0.01 \\
0.10 \\
(1982) \\
0.00 \\
(1983)\end{array}$ & $\begin{array}{r}0.00 \\
0.00 \\
(1983) \\
0.00 \\
(1983)\end{array}$ & $\begin{array}{l}--- \\
--- \\
--- \\
--- \\
---\end{array}$ & $\begin{array}{l}--- \\
--- \\
--- \\
--- \\
---\end{array}$ & $\begin{array}{l}--- \\
--- \\
--- \\
--- \\
---\end{array}$ & $\begin{array}{l}--- \\
--- \\
--- \\
--- \\
---\end{array}$ & $\begin{array}{r}0.00 \\
0.00 \\
(1983) \\
0.00 \\
(1983)\end{array}$ & $\begin{array}{r}0.00 \\
0.00 \\
(1992) \\
0.00 \\
(1982)\end{array}$ & $\begin{array}{r}0.00 \\
0.10 \\
(1988) \\
0.00 \\
(1981)\end{array}$ & $\begin{array}{r}0.02 \\
0.14 \\
(1991) \\
0.00 \\
(1981)\end{array}$ & $\begin{array}{r}0.03 \\
0.19 \\
(1999) \\
0.00 \\
(1982)\end{array}$ & $\begin{array}{r}0.01 \\
0.11 \\
(1990) \\
0.00 \\
(1982)\end{array}$ \\
\hline
\end{tabular}

SUMMARY STATISTICS

WATER YEARS 1981 - 2004

HIGHEST DAILY MEAN

LOWEST DAILY MEAN

ANNUAL SEVEN-DAY MINIMUM

MAXIMUM PEAK FLOW

MAXIMUM PEAK STAGE

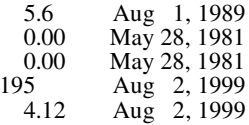

(+) Total precipitation accumulation, in inches. 


\section{SAN JOSE DRAIN AT WOODWARD ROAD AT ALBUQUERQUE, NEW MEXICO}

\section{STATION ANALYSIS}

\section{WATER YEAR 2004}

Equipment.-- An electronic datalogger and pressure transducer, recording on 5-minute intervals, have been used to collect gage height and rainfall data since September 23, 1999. Prior to this date, gage heights were recorded only during water-quality sampling. An ISCO model 3700 automatic pump sampler is also located in the gage house. Electricity is provided to the shelter. The instruments are housed in a 4- by 4- by 8 -foot brick walk-in building located approximately one-quarter mile west of the intersection of Woodward Road and South Broadway in Albuquerque. The shelter is immediately adjacent to the north shoulder of Woodward Road and directly over a 10-foot-diameter metal culvert. The channel is concrete-lined upstream from the culvert. Dowmstream, the natural channel is normally choked with weed growth. City maintenance crews clear the channel at least once each year. The reference gage is an outside staff painted on the concrete channel side-slope near the recorder orifice pipe. The staff is referenced to a tape-up point (RM1), which is a hex-head bolt anchored in the channel bottom approximately 1 foot streamward of the staff gage. Low- to medium-stage discharge measurements can be made by wading near the gage or downstream from the culvert.

Gage-Height Record.-- The recorder gave a complete and satisfactory record for the water year except for the period March 30-April 4 when the datalogger malfunctioned. The daily mean discharge was estimated as zero for March 30-April 1 because of the lack of precipitation in the watershed. Estimated daily mean discharges for April 2-4 were based on rainfall amounts and a reliable peak gage height on April 3 that was read from the recorder before it malfunctioned. Gage heights for this period were estimated by graphical methods and estimated daily means then computed.

Datum correction.-- Two recorder corrections were applied this water year. When the water level is not high enough to cover the orifice, an accurate gage height calibration is not possible, so opportunities to do so are limited. The site visit on April 3 provided an opportunity to correctly set the instrument and a +0.08 -foot correction was required for the period October 7-April 3. A second correction was applied for the period September 18-October 28, 2004. The orifice tubing was discovered pushed up into its conduit line during the site visit on October 13 and repaired on October 28, 2004. Gage height readings did not agree well with observed high-water marks since the flow of September 19 , so apparently, the problem occurred prior to that date. The data correction of +0.14 foot was based on the recorder calibration on October 28.

Rating.-- Rating 3.0 was developed for water year 2000 because rating 2.0 used theoretical discharge computations as input points for the rating curve, giving it an irregular shape. The new rating is basically the same as rating 2.0, with the exception of a smooth, "bestfit" line through these input points. Because of a very flat channel slope (approximately 0.0003 foot per foot), sediment and debris commonly accumulate in the culvert and 
channel, resulting in large negative shifts to the stage versus discharge rating. Occasionally, large sediment deposits in the culvert throat cause ponding at the gage orifice, but no flows exist downstream. The control is the 10-foot diameter culvert pipe for most flows, but the mud layer in the culvert or vegetative cover in the natural lined part of the channel downstream may act as the control during extremely low flows and times of sediment accumulation in the culvert. The orifice is mounted 0.60 foot above the bottom of the channel to prevent sediment accumulations from covering the sensor and affecting the gage height record. Because of this, discharge computations show a constant negative 0.60 -foot shift, or correction to the rating, below recorded gage heights of 0.61 foot. This technique eliminates computing a discharge when water levels are below the orifice. Prior to the June 23, 2003, repair, the orifice was mounted at an elevation of 0.50 foot, requiring a constant -0.50 -foot shift to the rating.

Discharge.-- One measurement (8) was completed on February 24, 2004, and indicates a positive difference to rating 3.0 of only 4.2 percent. The rated discharge is considered more accurate than a single computed discharge if the measurement is within 5 percent of the rating curve, so no shift was applied. Measurement 9 was completed during the next flow event on March 3 and it indicates a shift of +0.38 -foot. This value was prorated from zero at the beginning of the hydrograph to +0.38 by the peak stage as weed growth downstream from the concrete portion of the channel was partially washed out. During this time of dormancy, the biomass in the natural channel is easily removed, or at least matted down by significant flows, so flow efficiency increases, resulting in positive shifts to rating 3.0. During the growing season, vegetation can quickly re-establish itself, causing back-water effects, resulting in large negative shifts to the stage-discharge relationship.

Two measurements (10-11) were completed within an hour on April 3, 2004. This pair of measurements indicates that the +0.38 -foot shift from March 3 had increased to +1.05 feet as the downstream weed growth was further washed out by the large flow on April 3. No other discharge measurements occurred until the paired measurements (12-13) on October 13, 2004, which both computed a negative 0.64 -foot shift to rating 3.0. The negative shift was prorated from +1.05 feet on May 1, arbitrarily chosen to reflect the beginning of significant vegetation accumulation downstream of the culvert, to the -0.64 by October 13 . No other measurements were completed in this water year to better define the stage-discharge relationship.

Occasionally, negative shift values can be determined by hydrographic interpretations. Peak flows generally display a slower recession pattern after reaching the water level of a channel obstruction. The shift values coincide with the approximate maximum gage height resulting from daily trickle flows ponding in the area behind the mud "dam" in the channel, then slowly seeping into the sediment layers, resulting in a diurnal-type hydrograph. In reality, these tiny trickle flows would not registered on the datalogger in a clean channel. Field inspections are also valuable in determining ponded water depths upstream from the sediment bars, even though no flows are detected downstream. During water year 2004, no sediment dams existed in the culvert pipe under Woodward Road, so no additional shift corrections to rating 3.0 were required.

The peak gage height and discharge for water year 2004 occurred on July 23 and were 6.26 feet and 96 cubic feet per second, respectively.

Remarks.-- Records are fair due to heavy weed accumulations in the channel at the gage and downstream. Estimated discharges are poor. 
LOCATION.--Lat $35^{\circ} 02^{\prime} 56^{\prime \prime}$, long 106 $38^{\prime} 55^{\prime \prime}$, in NE $1 /{ }_{4}$ of SW $1 /{ }_{4}$ sec.32, T.10 E., R.3 E., Bernalillo County, Hydrologic Unit 13020203 , approximately 1/ ${ }_{4} \mathrm{mi}$ west of the intersection of Woodward Road and South Broadway on Albuquerqués south side. The gage is located on the right bank of San Jose Drain and the shoulder of Woodward Road where a corrugated metal culvert passes under Woodward.

DRAINAGE AREA.--1.95 $\mathrm{mi}^{2}$.

PERIOD OF RECORD.--October 1993 to September 23, 1999, only data during water-quality sampling events were recorded and never published in the USGS Annual Data report. September 23, 1999 to present, full year's data is recorded, along with rainfall.

GAGE.--Water-stage recorder, and since July 1998, a tipping bucket raingage on the roof of the gage house is operational. The channel is concrete-lined above Woodward Road and natural below. Elevation of gage is 4,946 ft above National Geodetic Vertical Datum of 1929, from topographic map.

REMARKS.--Records poor due to heavy mud and weed accumulation at gage and downstream. Mud accumulations and vegetative growth occurs in the channel and will affect the stage-discharge relationship. See tabulation below for monthly precipitation in inches.

DISCHARGE, CUBIC FEET PER SECOND

WATER YEAR OCTOBER 2003 TO SEPTEMBER 2004

\begin{tabular}{|c|c|c|c|c|c|c|c|c|c|c|c|c|}
\hline DAY & OCT & NOV & DEC & JAN & FEB & MAR & APR & MAY & JUN & JUL & AUG & SEP \\
\hline $\begin{array}{l}1 \\
2 \\
3 \\
4 \\
5\end{array}$ & $\begin{array}{l}0.00 \\
0.00 \\
0.17 \\
0.00 \\
0.00\end{array}$ & $\begin{array}{l}0.00 \\
0.00 \\
0.00 \\
0.00 \\
0.00\end{array}$ & $\begin{array}{l}0.00 \\
0.00 \\
0.00 \\
0.00 \\
0.00\end{array}$ & $\begin{array}{l}0.00 \\
0.00 \\
0.00 \\
0.00 \\
0.00\end{array}$ & $\begin{array}{l}0.00 \\
0.00 \\
0.00 \\
0.00 \\
0.00\end{array}$ & $\begin{array}{l}0.00 \\
0.12 \\
0.00 \\
7.1 \\
0.52\end{array}$ & $\begin{array}{c}\text { e } 0.00 \\
\text { e13 } \\
\text { e36 } \\
\text { e6.0 } \\
0.00\end{array}$ & $\begin{array}{l}0.00 \\
0.00 \\
0.00 \\
0.00 \\
0.00\end{array}$ & $\begin{array}{l}0.00 \\
0.00 \\
0.00 \\
0.00 \\
0.00\end{array}$ & $\begin{array}{l}0.00 \\
0.00 \\
0.00 \\
0.00 \\
0.00\end{array}$ & $\begin{array}{l}0.00 \\
0.07 \\
0.00 \\
0.00 \\
0.15\end{array}$ & $\begin{array}{l}0.00 \\
0.00 \\
0.00 \\
0.57 \\
0.03\end{array}$ \\
\hline $\begin{array}{r}6 \\
7 \\
8 \\
9 \\
10\end{array}$ & $\begin{array}{l}0.11 \\
5.9 \\
6.7 \\
0.00 \\
1.5\end{array}$ & $\begin{array}{l}0.00 \\
0.00 \\
0.00 \\
0.00 \\
0.00\end{array}$ & $\begin{array}{l}0.00 \\
0.00 \\
0.00 \\
0.00 \\
0.00\end{array}$ & $\begin{array}{l}0.00 \\
0.00 \\
0.00 \\
0.00 \\
0.00\end{array}$ & $\begin{array}{l}0.00 \\
0.00 \\
0.00 \\
0.00 \\
0.00\end{array}$ & $\begin{array}{l}0.00 \\
0.00 \\
0.00 \\
0.00 \\
0.00\end{array}$ & $\begin{array}{l}0.00 \\
0.00 \\
6.2 \\
0.00 \\
3.8\end{array}$ & $\begin{array}{l}0.00 \\
0.00 \\
0.00 \\
0.00 \\
0.00\end{array}$ & $\begin{array}{l}0.00 \\
0.00 \\
0.00 \\
0.00 \\
0.00\end{array}$ & $\begin{array}{l}0.00 \\
0.00 \\
0.00 \\
0.00 \\
0.00\end{array}$ & $\begin{array}{l}0.00 \\
0.00 \\
0.00 \\
0.00 \\
1.3\end{array}$ & $\begin{array}{l}0.00 \\
0.00 \\
0.00 \\
0.00 \\
0.00\end{array}$ \\
\hline $\begin{array}{l}11 \\
12 \\
13 \\
14 \\
15\end{array}$ & $\begin{array}{l}0.92 \\
0.00 \\
0.00 \\
0.00 \\
0.07\end{array}$ & $\begin{array}{l}0.00 \\
1.9 \\
1.9 \\
0.00 \\
0.00\end{array}$ & $\begin{array}{l}0.00 \\
0.00 \\
0.00 \\
0.00 \\
0.00\end{array}$ & $\begin{array}{l}0.00 \\
0.00 \\
0.00 \\
0.00 \\
0.00\end{array}$ & $\begin{array}{l}0.00 \\
0.00 \\
0.00 \\
0.00 \\
0.00\end{array}$ & $\begin{array}{l}0.00 \\
0.00 \\
0.00 \\
0.00 \\
0.00\end{array}$ & $\begin{array}{l}0.82 \\
0.00 \\
0.00 \\
0.00 \\
0.00\end{array}$ & $\begin{array}{l}0.00 \\
0.00 \\
0.16 \\
0.00 \\
8.8\end{array}$ & $\begin{array}{l}0.00 \\
0.00 \\
0.00 \\
0.00 \\
0.00\end{array}$ & $\begin{array}{l}0.00 \\
4.0 \\
4.2 \\
0.00 \\
5.3\end{array}$ & $\begin{array}{l}0.78 \\
0.00 \\
0.00 \\
0.00 \\
0.64\end{array}$ & $\begin{array}{l}0.00 \\
0.00 \\
0.00 \\
0.00 \\
0.00\end{array}$ \\
\hline $\begin{array}{l}16 \\
17 \\
18 \\
19 \\
20\end{array}$ & $\begin{array}{l}0.00 \\
0.00 \\
0.00 \\
0.00 \\
0.00\end{array}$ & $\begin{array}{l}0.00 \\
0.00 \\
0.00 \\
0.00 \\
0.00\end{array}$ & $\begin{array}{l}0.00 \\
0.00 \\
0.00 \\
0.00 \\
0.00\end{array}$ & $\begin{array}{l}0.00 \\
0.00 \\
0.00 \\
0.00 \\
0.00\end{array}$ & $\begin{array}{l}0.00 \\
0.00 \\
0.00 \\
0.00 \\
0.00\end{array}$ & $\begin{array}{l}0.00 \\
0.00 \\
0.00 \\
0.00 \\
0.00\end{array}$ & $\begin{array}{l}0.00 \\
0.00 \\
0.00 \\
0.00 \\
0.00\end{array}$ & $\begin{array}{l}8.1 \\
0.65 \\
3.3 \\
0.00 \\
0.00\end{array}$ & $\begin{array}{l}0.00 \\
0.00 \\
0.00 \\
0.00 \\
0.00\end{array}$ & $\begin{array}{l}5.8 \\
0.00 \\
0.26 \\
0.80 \\
1.0\end{array}$ & $\begin{array}{l}0.00 \\
0.00 \\
0.00 \\
0.00 \\
0.00\end{array}$ & $\begin{array}{c}0.00 \\
0.00 \\
0.00 \\
10 \\
4.1\end{array}$ \\
\hline $\begin{array}{l}21 \\
22 \\
23 \\
24 \\
25\end{array}$ & $\begin{array}{l}0.00 \\
0.00 \\
0.00 \\
0.00 \\
0.00\end{array}$ & $\begin{array}{l}0.00 \\
0.00 \\
0.00 \\
0.00 \\
0.00\end{array}$ & $\begin{array}{l}0.00 \\
0.00 \\
0.00 \\
0.00 \\
0.00\end{array}$ & $\begin{array}{l}0.00 \\
0.00 \\
0.00 \\
0.00 \\
0.00\end{array}$ & $\begin{array}{l}0.29 \\
0.00 \\
2.9 \\
5.2 \\
0.00\end{array}$ & $\begin{array}{l}0.45 \\
0.00 \\
0.00 \\
0.00 \\
0.00\end{array}$ & $\begin{array}{l}0.00 \\
0.00 \\
0.00 \\
0.00 \\
0.00\end{array}$ & $\begin{array}{l}0.00 \\
0.00 \\
0.00 \\
0.00 \\
0.00\end{array}$ & $\begin{array}{l}0.00 \\
0.00 \\
0.00 \\
0.00 \\
0.00\end{array}$ & $\begin{array}{c}0.00 \\
3.5 \\
17 \\
11 \\
8.8\end{array}$ & $\begin{array}{l}0.00 \\
0.00 \\
0.00 \\
0.00 \\
0.00\end{array}$ & $\begin{array}{l}0.00 \\
0.00 \\
0.00 \\
0.00 \\
0.00\end{array}$ \\
\hline $\begin{array}{l}26 \\
27 \\
28 \\
29 \\
30 \\
31\end{array}$ & $\begin{array}{l}0.00 \\
0.00 \\
0.00 \\
0.00 \\
0.00 \\
0.00\end{array}$ & $\begin{array}{l}0.00 \\
0.00 \\
0.00 \\
0.00 \\
0.00 \\
---\end{array}$ & $\begin{array}{l}0.00 \\
0.00 \\
0.00 \\
0.00 \\
0.00 \\
0.00\end{array}$ & $\begin{array}{l}0.00 \\
0.00 \\
0.00 \\
0.00 \\
0.00 \\
0.00\end{array}$ & $\begin{array}{l}0.00 \\
0.00 \\
0.48 \\
0.00 \\
--- \\
---\end{array}$ & $\begin{array}{l}0.00 \\
0.00 \\
0.00 \\
0.00 \\
0.00 \\
0.00\end{array}$ & $\begin{array}{l}0.00 \\
0.00 \\
0.00 \\
0.00 \\
0.00 \\
---\end{array}$ & $\begin{array}{l}0.00 \\
0.00 \\
0.00 \\
0.00 \\
0.00 \\
0.00\end{array}$ & $\begin{array}{l}0.00 \\
0.00 \\
0.91 \\
9.9 \\
0.00 \\
---\end{array}$ & $\begin{array}{l}0.00 \\
0.77 \\
0.89 \\
0.00 \\
0.00 \\
0.00\end{array}$ & $\begin{array}{l}0.00 \\
0.00 \\
0.00 \\
0.00 \\
0.00 \\
0.00\end{array}$ & $\begin{array}{l}0.00 \\
0.00 \\
0.00 \\
0.73 \\
0.02 \\
---\end{array}$ \\
\hline $\begin{array}{l}\text { IEAN } \\
\text { IAX } \\
\text { IIN } \\
\text { C-FT }\end{array}$ & $\begin{array}{l}0.50 \\
6.7 \\
0.00 \\
30\end{array}$ & $\begin{array}{l}0.13 \\
1.9 \\
0.00 \\
7.5\end{array}$ & $\begin{array}{l}0.00 \\
0.00 \\
0.00 \\
0.00\end{array}$ & $\begin{array}{l}0.00 \\
0.00 \\
0.00 \\
0.00\end{array}$ & $\begin{array}{l}0.31 \\
5.2 \\
0.00 \\
18\end{array}$ & $\begin{array}{l}0.26 \\
7.1 \\
0.00 \\
16\end{array}$ & $\begin{array}{c}2.19 \\
36 \\
0.00 \\
131\end{array}$ & $\begin{array}{l}0.68 \\
8.8 \\
0.00 \\
42\end{array}$ & $\begin{array}{l}0.36 \\
9.9 \\
0.00 \\
21\end{array}$ & $\begin{array}{c}2.04 \\
17 \\
0.00 \\
126\end{array}$ & $\begin{array}{l}0.09 \\
1.3 \\
0.00 \\
5.8\end{array}$ & $\begin{array}{c}0.52 \\
10 \\
0.00 \\
31\end{array}$ \\
\hline
\end{tabular}

STATISTICS OF MONTHLY MEAN DATA FOR WATER YEARS 1994 - 2004, BY WATER YEAR (WY)

$\begin{array}{lrrrrrrrrrrrr}\text { MEAN } & 0.36 & 0.21 & 0.08 & 0.06 & 0.22 & 0.16 & 0.34 & 0.27 & 0.33 & 0.83 & 0.98 & 0.74 \\ \text { MAX } & 1.16 & 0.73 & 0.20 & 0.20 & 0.62 & 0.73 & 2.19 & 0.99 & 1.79 & 2.21 & 2.10 & 2.07 \\ \text { (WY) } & (2001) & (1995) & (2003) & (1995) & (2003) & (2003) & (2004) & (1996) & (1996) & (2003) & (1996) & (1995) \\ \text { MIN } & 0.01 & 0.00 & 0.00 & 0.00 & 0.01 & 0.00 & 0.00 & 0.00 & 0.01 & 0.07 & 0.09 & 0.01 \\ \text { (WY) } & (2002) & (2000) & (2000) & (2000) & (2000) & (1996) & (2000) & (2000) & (1995) & (2002) & (2004) & (2000)\end{array}$

SUMMARY STATISTICS

ANNUAL MEAN

HIGHEST ANNUAL MEAN

LOWEST ANNUAL MEAN

HIGHEST DAILY MEAN

LOWEST DAILY MEAN

ANNUAL SEVEN-DAY MINIMUM

MAXIMUM PEAK FLOW

ANNUAL RUNOFF (AC-FT)

10 PERCENT EXCEEDS

50 PERCENT EXCEEDS

90 PERCENT EXCEEDS

e Estimated
FOR 2003 CALENDAR YEAR

$\begin{array}{ll}0.51 & \\ & \\ 7.9 & \text { Mar 21 } \\ 0.00 & \text { Jan } 6 \\ 0.00 & \text { Jan 11 } \\ & \\ & \\ 68 & \\ 2.0 & \\ 0.00 & \\ 0.00 & \end{array}$

FOR 2004 WATER YEAR

$\begin{array}{cc}0.59 & \\ & \\ 36 & \text { Apr } 3 \\ 0.00 & \text { Oct 1 } \\ 0.00 & \text { Oct 16 } \\ 96 & \text { Jul 23 } \\ 6.26 & \text { Jul 23 } \\ 428 & \\ 0.74 & \\ 0.00 & \\ 0.00 & \\ \end{array}$

WATER YEARS 1994 - 2004

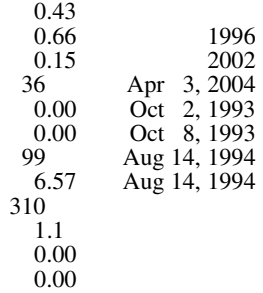




\section{TRAMWAY FLOODWAY CHANNEL AT ALBUQUERQUE, NEW MEXICO}

\section{STATION ANALYSIS}

\section{WATER YEAR 2004}

Equipment.-- An electronic datalogger and pressure transducer, recording on 5-minute intervals, are housed in a metal 5- by 5-foot walk-in shelter on the right bank of the concrete-lined channel. An outside staff gage is painted on the channel side slope and is the reference gage. A crest-stage gage, inclined 35 degrees from horizontal, was mounted to the right bank on October 22, 1998. Rainfall data from a tipping-bucket rain gage mounted to the gage house roof have been recorded by the datalogger since May 1, 2001. Prior to March 19, 1998, the pressure transducer orifice was mounted 0.12 foot above the channel bottom. On March 19, the orifice was lowered into a sump which is below the channel bottom so all gage heights above the point of zero flow (PZF) are recorded. The recorded gage height is 1.00 foot when the water level in the sump is equal to the channel bottom elevation, or PZF.

Gage-Height Record.-- The water-stage recorder, referenced to the outside staff gage, provided a complete and satisfactory record for the entire water year except for periods of iceaffected gage heights on January 22, 26-28, and February 1-6, 11, 14, and 17, 2004. Zero discharge was estimated for all ice-affected days. Estimations of mean daily discharges were determined by base-flow values available before and after the estimated period and precipitation records. No other gage is located on this channel that could provide a hydrographic comparison for estimating missing record at the Tramway Floodway station. Prior to water year 2002, the gage was not operational during the winter period from approximately November 15 to March 15.

Rating.-- The control for the gage is the concrete-lined channel. The depth of the channel at the gage is approximately 10 feet, and the bottom width is 10 feet. The side walls are inclined 35 degrees from horizontal. Rating 2.0 was effective from October 1, 1996, until March 19,1998 , when the orifice was lowered. Rating 2.0 is essentially identical to rating 1.0; the old rating, however, computed discharges for gage heights below the level of the orifice ( 0.12 foot). Because recording gage heights less than the orifice elevation is impossible, all discharges below the 0.12-foot gage height (less than 3.4 cubic feet per second) were computed as zero for rating 2.0.

Rating 3.0 was developed for the period after March 19, 1998, when all gage heights greater than the PZF are recorded. Rating 3.0 is identical to rating 1.0, except the PZF for rating 3.0 is 1.00 foot instead of 0.00 foot. All 3 ratings were developed by step-forward theoretical analysis because flow regimes here are super-critical.

Discharge.-- Estimations of missing record are based on only rainfall data and historic base flows. No upstream or downstream gage is available for hydrographic comparison. Small daily flows, probably from sprinkler system run-off, usually occur in the evening and early morning hours. 
During water year 2004, 14 site inspections were made. Small trickle flows were occasionally observed and the recorder was tracking them to correct water levels. The instantaneous peak stage and discharge for water year 2004 were 2.58 feet and 233 cubic feet per second, respectively, recorded on August 4.

Discharges were computed using rating curve 3.0 directly with no shifts. Flows probably cause enough turbulence in the orifice sump to wash out any debris that might affect gage heights. The channel slope in this reach creates extremely high velocities that make stream-flow measurements nearly impossible. Because of the stability of the channel, the theoretical rating curve is considered better than individual measurements. 
RIO GRANDE BASIN

08330540 TRAMWAY FLOODWAY CHANNEL AT ALBUQUERQUE, NM

LOCATION.--Lat 3504'42", long 106²9'49", Bernalillo County, Hydrologic Unit 13020203, on right bank $300 \mathrm{ft}$ downstream from Copper Boulevard Bridge, near corner of Tramway and Copper Boulevards NE in Albuquerque.

DRAINAGE AREA.--1.60 $\mathrm{mi}^{2}$.

PERIOD OF RECORD.--July 1987 to November 2000 (seasonal record), March 2001 to current year.

GAGE.--Water-stage recorder, crest-stage gage, and concrete-lined channel. Recording rain gage at this site since May 2001. Elevation of gage is 5,740 ft above National Geodetic Vertical Datum of 1929, from topographic map.

REMARKS.--Records good except for those estimated, which are poor. Prior to water year 1998, some minor streamflow may have existed on days when daily mean discharges have been recorded as zero due to the sensitivity limits of the streamflow-monitoring equipment. Since 1998, all flows above zero are recorded. See tabulation below for monthly precipitation, in inches.

DISCHARGE, CUBIC FEET PER SECOND

WATER YEAR OCTOBER 2003 TO SEPTEMBER 2004

\begin{tabular}{|c|c|c|c|c|c|c|c|c|c|c|c|c|}
\hline DAY & OCT & NOV & DEC & JAN & FEB & MAR & APR & MAY & JUN & JUL & AUG & SEP \\
\hline $\begin{array}{l}1 \\
2 \\
3 \\
4 \\
5\end{array}$ & $\begin{array}{l}0.04 \\
0.24 \\
0.19 \\
0.09 \\
0.00\end{array}$ & $\begin{array}{l}0.01 \\
0.01 \\
0.01 \\
0.02 \\
0.02\end{array}$ & $\begin{array}{l}0.00 \\
0.04 \\
0.00 \\
0.00 \\
0.01\end{array}$ & $\begin{array}{l}0.00 \\
0.00 \\
0.00 \\
0.00 \\
0.00\end{array}$ & $\begin{array}{l}\text { e0.00 } \\
\text { e0.00 } \\
\text { e0.00 } \\
\text { e0.00 } \\
\text { e0.00 }\end{array}$ & $\begin{array}{l}0.01 \\
0.48 \\
0.14 \\
4.6 \\
0.77\end{array}$ & $\begin{array}{l}0.01 \\
1.5 \\
8.2 \\
2.8 \\
0.08\end{array}$ & $\begin{array}{l}0.07 \\
0.14 \\
0.04 \\
0.09 \\
0.09\end{array}$ & $\begin{array}{l}0.12 \\
0.11 \\
0.19 \\
0.24 \\
0.08\end{array}$ & $\begin{array}{l}0.72 \\
0.63 \\
0.73 \\
0.76 \\
0.67\end{array}$ & $\begin{array}{l}0.08 \\
0.93 \\
0.18 \\
9.4 \\
0.14\end{array}$ & $\begin{array}{l}0.14 \\
0.17 \\
0.16 \\
0.90 \\
0.19\end{array}$ \\
\hline $\begin{array}{r}6 \\
7 \\
8 \\
9 \\
10\end{array}$ & $\begin{array}{l}0.01 \\
4.3 \\
1.1 \\
0.03 \\
1.3\end{array}$ & $\begin{array}{l}0.00 \\
0.01 \\
0.01 \\
0.00 \\
0.01\end{array}$ & $\begin{array}{l}0.00 \\
0.00 \\
0.04 \\
0.20 \\
0.02\end{array}$ & $\begin{array}{l}0.00 \\
0.00 \\
0.00 \\
0.00 \\
0.00\end{array}$ & $\begin{array}{r}\mathrm{e} 0.00 \\
0.00 \\
0.00 \\
0.00 \\
0.00\end{array}$ & $\begin{array}{l}0.01 \\
0.00 \\
0.01 \\
0.00 \\
0.00\end{array}$ & $\begin{array}{l}0.02 \\
0.04 \\
1.8 \\
0.56 \\
1.3\end{array}$ & $\begin{array}{l}0.09 \\
0.02 \\
0.01 \\
0.29 \\
0.16\end{array}$ & $\begin{array}{l}0.05 \\
0.09 \\
0.09 \\
0.09 \\
0.10\end{array}$ & $\begin{array}{l}0.70 \\
0.84 \\
0.77 \\
1.1 \\
0.97\end{array}$ & $\begin{array}{l}0.06 \\
0.06 \\
0.09 \\
0.09 \\
0.24\end{array}$ & $\begin{array}{l}0.14 \\
0.16 \\
0.14 \\
0.16 \\
0.14\end{array}$ \\
\hline $\begin{array}{l}11 \\
12 \\
13 \\
14 \\
15\end{array}$ & $\begin{array}{l}0.26 \\
0.42 \\
0.09 \\
0.10 \\
0.14\end{array}$ & $\begin{array}{l}0.04 \\
2.2 \\
1.1 \\
0.01 \\
0.01\end{array}$ & $\begin{array}{l}0.04 \\
1.2 \\
0.02 \\
0.00 \\
0.00\end{array}$ & $\begin{array}{l}0.00 \\
0.00 \\
0.00 \\
0.00 \\
0.26\end{array}$ & $\begin{array}{r}\mathrm{e} 0.00 \\
0.00 \\
0.00 \\
\mathrm{e} 0.00 \\
0.00\end{array}$ & $\begin{array}{l}0.01 \\
0.02 \\
0.01 \\
0.01 \\
0.00\end{array}$ & $\begin{array}{l}0.06 \\
0.00 \\
0.01 \\
0.00 \\
0.01\end{array}$ & $\begin{array}{l}0.03 \\
0.01 \\
0.01 \\
0.00 \\
0.01\end{array}$ & $\begin{array}{l}0.09 \\
0.11 \\
0.08 \\
0.08 \\
0.08\end{array}$ & $\begin{array}{l}1.4 \\
0.86 \\
0.13 \\
0.97 \\
0.18\end{array}$ & $\begin{array}{l}0.29 \\
0.14 \\
0.10 \\
0.16 \\
0.14\end{array}$ & $\begin{array}{l}0.09 \\
0.15 \\
0.16 \\
0.16 \\
0.10\end{array}$ \\
\hline $\begin{array}{l}16 \\
17 \\
18 \\
19 \\
20\end{array}$ & $\begin{array}{l}0.06 \\
0.09 \\
0.15 \\
0.06 \\
0.06\end{array}$ & $\begin{array}{l}0.00 \\
0.13 \\
0.01 \\
0.01 \\
0.00\end{array}$ & $\begin{array}{l}0.00 \\
0.00 \\
0.00 \\
0.00 \\
0.00\end{array}$ & $\begin{array}{l}0.04 \\
0.00 \\
0.00 \\
0.00 \\
0.61\end{array}$ & $\begin{array}{r}0.00 \\
\mathrm{e} 0.00 \\
0.00 \\
0.00 \\
0.00\end{array}$ & $\begin{array}{l}0.03 \\
0.05 \\
0.03 \\
0.04 \\
0.09\end{array}$ & $\begin{array}{l}0.01 \\
0.02 \\
0.00 \\
0.02 \\
0.03\end{array}$ & $\begin{array}{l}0.02 \\
0.01 \\
0.03 \\
0.04 \\
0.02\end{array}$ & $\begin{array}{l}0.07 \\
0.11 \\
0.09 \\
0.12 \\
0.15\end{array}$ & $\begin{array}{l}0.12 \\
0.09 \\
0.14 \\
0.14 \\
0.62\end{array}$ & $\begin{array}{l}0.10 \\
0.14 \\
0.05 \\
0.32 \\
0.13\end{array}$ & $\begin{array}{l}0.16 \\
0.09 \\
0.20 \\
2.9 \\
1.3\end{array}$ \\
\hline $\begin{array}{l}21 \\
22 \\
23 \\
24 \\
25\end{array}$ & $\begin{array}{l}0.26 \\
0.02 \\
0.02 \\
0.07 \\
0.01\end{array}$ & $\begin{array}{l}0.00 \\
0.00 \\
0.00 \\
0.00 \\
0.00\end{array}$ & $\begin{array}{l}0.00 \\
0.00 \\
0.00 \\
0.00 \\
0.00\end{array}$ & $\begin{array}{r}0.00 \\
\mathrm{e} 0.00 \\
0.00 \\
0.00 \\
0.39\end{array}$ & $\begin{array}{l}0.69 \\
0.01 \\
6.0 \\
1.5 \\
0.05\end{array}$ & $\begin{array}{l}0.02 \\
0.06 \\
0.28 \\
0.12 \\
0.07\end{array}$ & $\begin{array}{l}0.12 \\
0.16 \\
0.27 \\
0.47 \\
0.65\end{array}$ & $\begin{array}{l}0.03 \\
0.04 \\
0.17 \\
0.50 \\
0.03\end{array}$ & $\begin{array}{l}0.14 \\
0.53 \\
0.43 \\
0.48 \\
0.51\end{array}$ & $\begin{array}{l}0.15 \\
1.0 \\
2.8 \\
0.51 \\
1.3\end{array}$ & $\begin{array}{l}0.26 \\
0.45 \\
0.14 \\
0.16 \\
0.11\end{array}$ & $\begin{array}{l}0.20 \\
0.12 \\
0.18 \\
0.10 \\
0.08\end{array}$ \\
\hline $\begin{array}{l}26 \\
27 \\
28 \\
29 \\
30 \\
31\end{array}$ & $\begin{array}{l}0.00 \\
0.01 \\
0.01 \\
0.01 \\
0.00 \\
0.01\end{array}$ & $\begin{array}{c}0.00 \\
0.00 \\
0.00 \\
0.00 \\
0.00 \\
---\end{array}$ & $\begin{array}{l}0.00 \\
0.00 \\
0.00 \\
0.00 \\
0.00 \\
0.00\end{array}$ & $\begin{array}{r}\mathrm{e} 0.00 \\
\mathrm{e} 0.00 \\
\mathrm{e} 0.00 \\
0.00 \\
0.00 \\
0.00\end{array}$ & $\begin{array}{l}0.00 \\
0.00 \\
1.3 \\
0.00 \\
--- \\
---\end{array}$ & $\begin{array}{l}0.07 \\
0.06 \\
0.02 \\
0.05 \\
0.04 \\
0.02\end{array}$ & $\begin{array}{l}0.89 \\
1.2 \\
1.4 \\
0.12 \\
0.14 \\
---\end{array}$ & $\begin{array}{l}0.03 \\
0.03 \\
0.02 \\
0.02 \\
0.87 \\
0.01\end{array}$ & $\begin{array}{l}1.7 \\
0.63 \\
4.7 \\
2.9 \\
0.73 \\
---\end{array}$ & $\begin{array}{l}0.09 \\
2.5 \\
0.17 \\
0.12 \\
0.10 \\
0.09\end{array}$ & $\begin{array}{l}0.16 \\
0.12 \\
0.14 \\
0.22 \\
0.16 \\
0.17\end{array}$ & $\begin{array}{l}0.10 \\
0.09 \\
0.11 \\
0.09 \\
0.13 \\
---\end{array}$ \\
\hline $\begin{array}{l}\text { TOTAL } \\
\text { MEAN } \\
\text { MAX } \\
\text { MIN } \\
\text { AC-FT } \\
\text { (+) }\end{array}$ & $\begin{array}{c}9.15 \\
0.30 \\
4.3 \\
0.00 \\
18 \\
1.39\end{array}$ & $\begin{array}{l}3.61 \\
0.12 \\
2.2 \\
0.00 \\
7.2 \\
1.06\end{array}$ & $\begin{array}{l}1.57 \\
0.05 \\
1.2 \\
0.00 \\
3.1 \\
0.22\end{array}$ & $\begin{array}{l}1.30 \\
0.04 \\
0.61 \\
0.00 \\
2.6 \\
0.32\end{array}$ & $\begin{array}{c}9.55 \\
0.33 \\
6.0 \\
0.00 \\
19 \\
1.80\end{array}$ & $\begin{array}{c}7.12 \\
0.23 \\
4.6 \\
0.00 \\
14 \\
0.97\end{array}$ & $\begin{array}{c}21.89 \\
0.73 \\
8.2 \\
0.00 \\
43 \\
2.84\end{array}$ & $\begin{array}{l}2.93 \\
0.09 \\
0.87 \\
0.00 \\
5.8 \\
0.00\end{array}$ & $\begin{array}{c}14.89 \\
0.50 \\
4.7 \\
0.05 \\
30 \\
1.56\end{array}$ & $\begin{array}{c}21.37 \\
0.69 \\
2.8 \\
0.09 \\
42 \\
2.03\end{array}$ & $\begin{array}{c}14.93 \\
0.48 \\
9.4 \\
0.05 \\
30 \\
1.88\end{array}$ & $\begin{array}{c}8.81 \\
0.29 \\
2.9 \\
0.08 \\
17 \\
0.94\end{array}$ \\
\hline \multicolumn{13}{|c|}{ STATISTICS OF MONTHLY MEAN DATA FOR WATER YEARS 1990 - 2004, BY WATER YEAR (WY) } \\
\hline $\begin{array}{l}\text { MEAN } \\
\text { MAX } \\
\text { (WY) } \\
\text { MIN } \\
\text { (WY) }\end{array}$ & $\begin{array}{r}0.25 \\
1.03 \\
(1990) \\
0.00 \\
(1991)\end{array}$ & $\begin{array}{r}0.09 \\
0.38 \\
(2002) \\
0.00 \\
(1990)\end{array}$ & $\begin{array}{r}0.08 \\
0.17 \\
(2002) \\
0.00 \\
(1990)\end{array}$ & $\begin{array}{r}0.11 \\
0.29 \\
(2002) \\
0.00 \\
(2003)\end{array}$ & $\begin{array}{r}0.25 \\
0.33 \\
(2004) \\
0.09 \\
(2002)\end{array}$ & $\begin{array}{r}0.30 \\
1.17 \\
(1990) \\
0.00 \\
(1991)\end{array}$ & $\begin{array}{r}0.15 \\
0.73 \\
(2004) \\
0.00 \\
(1991)\end{array}$ & $\begin{array}{r}0.12 \\
0.38 \\
(1998) \\
0.00 \\
(1995)\end{array}$ & $\begin{array}{r}0.15 \\
0.50 \\
(2004) \\
0.00 \\
(1990)\end{array}$ & $\begin{array}{r}0.38 \\
0.95 \\
(1998) \\
0.00 \\
(1994)\end{array}$ & $\begin{array}{r}0.49 \\
1.44 \\
(2001) \\
0.00 \\
(1994)\end{array}$ & $\begin{array}{r}0.24 \\
0.93 \\
(1991) \\
0.00 \\
(1990)\end{array}$ \\
\hline
\end{tabular}

SUMMARY STATISTICS

ANNUAL TOTAL

ANNUAL MEAN

LOWEST ANNUAL MEAN

HIGHEST DAILY MEAN

LOWEST DAILY MEAN

ANNUAL SEVEN-DAY MINIMUM

MAXIMUM PEAK FLOW

ANNUAL RUNOFF (AC-FT)

ANNUAL RUNOFF (AC-FT)

10 PERCENT EXCEEDS

90 PERCENT EXCEEDS
FOR 2003 CALENDAR YEAR

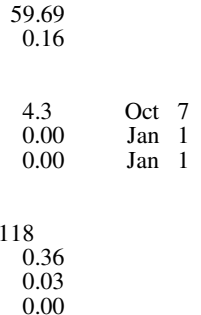

FOR 2004 WATER YEAR

\begin{tabular}{|c|c|}
\hline $\begin{array}{r}117.1 \\
0.3\end{array}$ & \\
\hline 9.4 & Aug 4 \\
\hline 0.0 & Oct 5 \\
\hline 0.0 & Nov 20 \\
\hline 233 & Aug 4 \\
\hline 2.5 & Aug 4 \\
\hline 232 & \\
\hline 0.8 & \\
\hline 0.0 & \\
\hline & \\
\hline
\end{tabular}

WATER YEARS 1990 - 2004

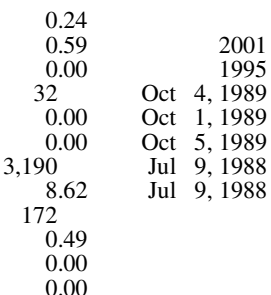

(+) Total precipitation accumulation, in inches

e Estimated 


\section{TIJERAS ARROYO NEAR ALBUQUERQUE, NEW MEXICO}

\section{STATION ANALYSIS}

\section{WATER YEAR 2004}

Equipment.-- An electronic datalogger, recording on 5-minute intervals, is housed in a metal 34- by 34-inch shelter over a 24 -inch-diameter, 10 -foot long, corrugated metal stilling well. The stilling well is recessed into the left streambank and is accessed by a 4- by 8foot expanded metal walkway. The walkway also serves as a support for the well and is anchored into the bank with steel angle-iron braces. Outside and inside staff gages are available as references to the gage datum. An electric-tape gage was installed as an additional reference gage on July 9, 1998. A peak stage indicator clip was attached to the float tape on March 17, 1998.

Gage-Height Record.-- The water-stage recorder, which is referenced to the inside staff and electric-tape gages, gave a complete and satisfactory record for water year 2004, except October 8, 2003, and February 24, March 4, April 4, June 29, July 25, and August 5, 2004, when silt was deposited in the well. This sediment commonly accumulates during the recession of a hydrograph and may suspend the recorder float above the channel bottom elevation, as happened each of the days listed above. The final hours of each of these day's flow hydrographs were estimated by graphical methods with little loss in accurracy, and the estimated gage heights were re-entered into the database to compute a mean daily discharge. No flows occur at this site without substantial rainfall or snowmelt runoff in the upper drainage basin. This station recorded gage heights continuously during the entire water year. Prior to water year 1999, it was not operated during the winter months.

Rating.-- The channel is straight for at least 1,000 feet upstream and downstream from the gage. Steep cut banks on both sides of the channel are approximately 4 feet high and partially covered with vegetation. The channel bottom is approximatley 30 feet wide and is comprised of very loose sand that is prone to extreme shifting. The channel bottom elevation, or PZF, may change many times throughout the year and is critical in the determination of shift values because most flows cannot be measured. A hydrograph generally indicates the point of zero flow becuase ponded water remains in the stilling well long after flows cease. Field recordings of channel bottom elevations also confirm that the channel alternates between aggrading and scouring conditions.

Measuring conditions at this site are poor. Generally, low flows are shallow and characterized by high velocities and uneven measuring sections. Peak flows are flashy and change so quickly that mean gage heights for measurements are difficult to determine. High-water measurements are made by indirect methods. Even poorly rated measurements are often used to define a shift because measurements are so difficult to obtain at this site.

Rating 4.0 was developed in water year 1997 and began on October 1, 1996. The upper end of the rating is based on a theoretical step-backwater analysis and is verified by a slope-area indirect measurement (\#22) on July 9, 1996. Rating 4.0 was used through 
water year 2000. Measurements 56 and 57, completed in water year 2001, plot left (negative) of rating curve 4.0, as do all measurements from water year 2000, so a new rating, 5.0, was developed in water year 2001 and continued through water year 2004. Two measurements (\#63\#64) were completed by the conventional current-meter method in water year 2004. A slope-area indirect measurement (\#65) was also computed for the flow on August 4, 2004. The high-flow indirect measurement of 910 cubic feet per second verifies rating 5.0 within 2.1 percent. The poorly-rated measurement 63 indicates a shift of -0.20 feet to rating 5.0, but since measuring accuracy at this site is very poor for discharges under 0.5 cubic feet per second, such as this, the shift was not used. More reliable measurements of PZF's were used to determine the shift value. Measurement 64 indicated a shift of +0.28 feet to rating 5.0, and because it was rated good, the shift value was applied during that time period. Because of the extremely variable sand channel, most flows scour or aggrade the bed slightly, making developement of a standard rating curve difficult.

Discharge.-- During water year 2004, 33 no-flow site visits and 3 discharge measurements were completed. The instantaneous peak stage and discharge for the water year were 6.49 feet and 929 cubic feet per second, respectively, on August 4, 2004.

A negative shift was being applied to rating 5.0 at the end of water year 2003 . This -0.05 foot shift correction was based on channel bottom elevations measured during field inspections that were approximately 0.05 foot higher than the rated PZF gage height of 2.75 feet. Beginning with the recession of the October 7-8 hydrograpgh, a negative 0.15 -foot shift was applied because channel aggradation raised the point of zero flow to approximately 2.90 feet. Generally, aggradations occur as the discharge decreases and sediment drops out of suspension. Field inspections indicated that the channel bottom remained fairly undisturbed until the flow of April 2-3, 2004. Measurement 64, completed on April 3 indicated a positive 0.28-foot shift and PZF readings of approximately 2.45 feet confirm this shift value. The negative 0.15 -foot shift was prorated to the positive 0.28 -foot shift during the rise of the hydrograph, which is normally when scouring occurs. The PZF remained at a gage height of approximately 2.45 feet until the peak of year on August 4, 2004. The PZF was scoured to a gage height of approximately 1.75 feet, inidcating a positive 1.00 -foot shift to rating 5.0. This shift change was prorated from a positive 0.28 foot to 1.00 foot during the rising limb of the hydrograph on August 4 . This +1.00 -foot shift was continued through the end of the water year.

Remarks.-- Records good except when the stilling well silted, resulting in estimated gage heights during the falling side of the hydrograph. The estimated daily mean discharges for these 7 days are considered "fair record". 
LOCATION.--Lat 3500'10", long 106³8'53", in SW 1/ ${ }_{4} \mathrm{SW}^{1}$ / ${ }_{4}$ sec.17, T.9 N., R.3 E., Bernalillo County, Hydrologic Unit 13020203 , on left bank 800 ft upstream from bridge on Broadway Boulevard SE, 0.2 mi downstream from bridge on Interstate Highway 25 , and 3.0 mi south of Albuquerque.

DRAINAGE AREA.--128 $\mathrm{mi}^{2}$.

PERIOD OF RECORD.--October 1951 to September 1968 (annual maximum only), August 1974 to September 1998 (seasonal records), October 1998 to current year.

GAGE.--Water-stage recorder. Elevation of gage is 4,999 ft above National Geodetic Vertical Datum of 1929, from topographic map. Prior to Mar. 10, 1988, at site $1,700 \mathrm{ft}$ downstream at different datum.

REMARKS.--Records good except for those estimated, which are fair.

DISCHARGE, CUBIC FEET PER SECOND

WATER YEAR OCTOBER 2003 TO SEPTEMBER 2004

\begin{tabular}{|c|c|c|c|c|c|c|c|c|c|c|c|c|}
\hline DAY & OCT & NOV & DEC & JAN & FEB & MAR & APR & MAY & JUN & JUL & AUG & SEP \\
\hline $\begin{array}{l}1 \\
2 \\
3 \\
4 \\
5\end{array}$ & $\begin{array}{l}0.00 \\
0.00 \\
0.00 \\
0.00 \\
0.00\end{array}$ & $\begin{array}{l}0.00 \\
0.00 \\
0.00 \\
0.00 \\
0.00\end{array}$ & $\begin{array}{l}0.00 \\
0.00 \\
0.00 \\
0.00 \\
0.00\end{array}$ & $\begin{array}{l}0.00 \\
0.00 \\
0.00 \\
0.00 \\
0.00\end{array}$ & $\begin{array}{l}0.00 \\
0.00 \\
0.00 \\
0.00 \\
0.00\end{array}$ & $\begin{array}{r}0.00 \\
0.00 \\
0.00 \\
\mathrm{e} 15 \\
0.00\end{array}$ & $\begin{array}{l}0.00 \\
5.1 \\
88 \\
\mathrm{e} 3.2 \\
0.00\end{array}$ & $\begin{array}{l}0.00 \\
0.00 \\
0.00 \\
0.00 \\
0.00\end{array}$ & $\begin{array}{l}0.00 \\
0.00 \\
0.00 \\
0.00 \\
0.00\end{array}$ & $\begin{array}{l}0.00 \\
0.00 \\
0.00 \\
0.00 \\
0.00\end{array}$ & $\begin{array}{c}0.00 \\
0.00 \\
0.00 \\
58 \\
\mathrm{e} 1.3\end{array}$ & $\begin{array}{l}0.00 \\
0.00 \\
0.00 \\
0.00 \\
0.00\end{array}$ \\
\hline $\begin{array}{r}6 \\
7 \\
8 \\
9 \\
10\end{array}$ & $\begin{array}{l}0.00 \\
37 \\
\mathrm{e} 5.9 \\
0.00 \\
6.7\end{array}$ & $\begin{array}{l}0.00 \\
0.00 \\
0.00 \\
0.00 \\
0.00\end{array}$ & $\begin{array}{l}0.00 \\
0.00 \\
0.00 \\
0.00 \\
0.00\end{array}$ & $\begin{array}{l}0.00 \\
0.00 \\
0.00 \\
0.00 \\
0.00\end{array}$ & $\begin{array}{l}0.00 \\
0.00 \\
0.00 \\
0.00 \\
0.00\end{array}$ & $\begin{array}{l}0.00 \\
0.00 \\
0.00 \\
0.00 \\
0.00\end{array}$ & $\begin{array}{l}0.00 \\
0.00 \\
7.3 \\
0.00 \\
0.00\end{array}$ & $\begin{array}{l}0.00 \\
0.00 \\
0.00 \\
0.00 \\
0.00\end{array}$ & $\begin{array}{l}0.00 \\
0.00 \\
0.00 \\
0.00 \\
0.00\end{array}$ & $\begin{array}{l}0.00 \\
0.00 \\
0.00 \\
0.00 \\
0.00\end{array}$ & $\begin{array}{l}0.00 \\
0.00 \\
0.00 \\
0.00 \\
0.00\end{array}$ & $\begin{array}{l}0.00 \\
0.00 \\
0.00 \\
0.00 \\
0.00\end{array}$ \\
\hline $\begin{array}{l}11 \\
12 \\
13 \\
14 \\
15\end{array}$ & $\begin{array}{l}0.40 \\
0.00 \\
0.00 \\
0.00 \\
0.00\end{array}$ & $\begin{array}{l}0.00 \\
0.45 \\
2.3 \\
0.00 \\
0.00\end{array}$ & $\begin{array}{l}0.00 \\
0.00 \\
0.00 \\
0.00 \\
0.00\end{array}$ & $\begin{array}{l}0.00 \\
0.00 \\
0.00 \\
0.00 \\
0.00\end{array}$ & $\begin{array}{l}0.00 \\
0.00 \\
0.00 \\
0.00 \\
0.00\end{array}$ & $\begin{array}{l}0.00 \\
0.00 \\
0.00 \\
0.00 \\
0.00\end{array}$ & $\begin{array}{l}0.00 \\
0.00 \\
0.00 \\
0.00 \\
0.00\end{array}$ & $\begin{array}{l}0.00 \\
0.00 \\
0.00 \\
0.00 \\
0.00\end{array}$ & $\begin{array}{l}0.00 \\
0.00 \\
0.00 \\
0.00 \\
0.00\end{array}$ & $\begin{array}{l}0.00 \\
0.00 \\
0.00 \\
0.00 \\
0.00\end{array}$ & $\begin{array}{l}0.00 \\
0.00 \\
0.00 \\
1.7 \\
0.00\end{array}$ & $\begin{array}{l}0.00 \\
0.00 \\
0.00 \\
0.00 \\
0.00\end{array}$ \\
\hline $\begin{array}{l}16 \\
17 \\
18 \\
19 \\
20\end{array}$ & $\begin{array}{l}0.00 \\
0.00 \\
0.00 \\
0.00 \\
0.00\end{array}$ & $\begin{array}{l}0.00 \\
0.00 \\
0.00 \\
0.00 \\
0.00\end{array}$ & $\begin{array}{l}0.00 \\
0.00 \\
0.00 \\
0.00 \\
0.00\end{array}$ & $\begin{array}{l}0.00 \\
0.00 \\
0.00 \\
0.00 \\
0.00\end{array}$ & $\begin{array}{l}0.00 \\
0.00 \\
0.00 \\
0.00 \\
0.00\end{array}$ & $\begin{array}{l}0.00 \\
0.00 \\
0.00 \\
0.00 \\
0.00\end{array}$ & $\begin{array}{l}0.00 \\
0.00 \\
0.00 \\
0.00 \\
0.00\end{array}$ & $\begin{array}{l}0.00 \\
0.00 \\
0.00 \\
0.00 \\
0.00\end{array}$ & $\begin{array}{l}0.00 \\
0.00 \\
0.00 \\
0.00 \\
0.00\end{array}$ & $\begin{array}{l}0.00 \\
0.00 \\
0.00 \\
0.00 \\
0.00\end{array}$ & $\begin{array}{l}0.00 \\
0.00 \\
0.00 \\
0.00 \\
0.00\end{array}$ & $\begin{array}{l}0.00 \\
0.00 \\
0.00 \\
1.2 \\
0.00\end{array}$ \\
\hline $\begin{array}{l}21 \\
22 \\
23 \\
24 \\
25\end{array}$ & $\begin{array}{l}0.00 \\
0.00 \\
0.00 \\
0.00 \\
0.00\end{array}$ & $\begin{array}{l}0.00 \\
0.00 \\
0.00 \\
0.00 \\
0.00\end{array}$ & $\begin{array}{l}0.00 \\
0.00 \\
0.00 \\
0.00 \\
0.00\end{array}$ & $\begin{array}{l}0.00 \\
0.00 \\
0.00 \\
0.00 \\
0.00\end{array}$ & $\begin{array}{c}0.00 \\
0.00 \\
16 \\
\mathrm{e} 16 \\
0.00\end{array}$ & $\begin{array}{l}0.00 \\
0.00 \\
0.00 \\
0.00 \\
0.00\end{array}$ & $\begin{array}{l}0.00 \\
0.00 \\
0.00 \\
0.00 \\
0.00\end{array}$ & $\begin{array}{l}0.00 \\
0.00 \\
0.00 \\
0.00 \\
0.00\end{array}$ & $\begin{array}{l}0.00 \\
0.00 \\
0.00 \\
0.00 \\
0.00\end{array}$ & $\begin{array}{c}0.00 \\
6.9 \\
40 \\
1.4 \\
\mathrm{e} 3.8\end{array}$ & $\begin{array}{l}0.00 \\
0.00 \\
0.00 \\
0.00 \\
0.00\end{array}$ & $\begin{array}{l}0.00 \\
0.00 \\
0.00 \\
0.00 \\
0.00\end{array}$ \\
\hline $\begin{array}{l}26 \\
27 \\
28 \\
29 \\
30 \\
31\end{array}$ & $\begin{array}{l}0.00 \\
0.00 \\
0.00 \\
0.00 \\
0.00 \\
0.00\end{array}$ & $\begin{array}{l}0.00 \\
0.00 \\
0.00 \\
0.00 \\
0.00 \\
---\end{array}$ & $\begin{array}{l}0.00 \\
0.00 \\
0.00 \\
0.00 \\
0.00 \\
0.00\end{array}$ & $\begin{array}{l}0.00 \\
0.00 \\
0.00 \\
0.00 \\
0.00 \\
0.00\end{array}$ & $\begin{array}{l}0.00 \\
0.00 \\
0.00 \\
0.00 \\
--- \\
---\end{array}$ & $\begin{array}{l}0.00 \\
0.00 \\
0.00 \\
0.00 \\
0.00 \\
0.00\end{array}$ & $\begin{array}{l}0.00 \\
0.00 \\
0.00 \\
0.00 \\
0.00 \\
---\end{array}$ & $\begin{array}{l}0.00 \\
0.00 \\
0.00 \\
0.00 \\
0.00 \\
0.00\end{array}$ & $\begin{array}{c}0.00 \\
0.00 \\
21 \\
\mathrm{e} 4.1 \\
0.00 \\
---\end{array}$ & $\begin{array}{l}0.00 \\
0.00 \\
0.03 \\
0.00 \\
0.00 \\
0.00\end{array}$ & $\begin{array}{l}0.00 \\
0.00 \\
0.00 \\
0.00 \\
0.00 \\
0.00\end{array}$ & $\begin{array}{c}0.00 \\
0.00 \\
0.00 \\
0.00 \\
0.00 \\
---\end{array}$ \\
\hline $\begin{array}{l}\text { TOTAL } \\
\text { MEAN } \\
\text { MAX } \\
\text { MIN } \\
\text { AC-FT }\end{array}$ & $\begin{array}{c}50.00 \\
1.61 \\
37 \\
0.00 \\
99\end{array}$ & $\begin{array}{l}2.75 \\
0.09 \\
2.3 \\
0.00 \\
5.5\end{array}$ & $\begin{array}{l}0.00 \\
0.00 \\
0.00 \\
0.00 \\
0.00\end{array}$ & $\begin{array}{l}0.00 \\
0.00 \\
0.00 \\
0.00 \\
0.00\end{array}$ & $\begin{array}{c}32.00 \\
1.10 \\
16 \\
0.00 \\
63\end{array}$ & $\begin{array}{c}15.00 \\
0.48 \\
15 \\
0.00 \\
30\end{array}$ & $\begin{array}{c}103.60 \\
3.45 \\
88 \\
0.00 \\
205\end{array}$ & $\begin{array}{l}0.00 \\
0.00 \\
0.00 \\
0.00 \\
0.00\end{array}$ & $\begin{array}{c}25.10 \\
0.84 \\
21 \\
0.00 \\
50\end{array}$ & $\begin{array}{c}52.13 \\
1.68 \\
40 \\
0.00 \\
103\end{array}$ & $\begin{array}{c}61.00 \\
1.97 \\
58 \\
0.00 \\
121\end{array}$ & $\begin{array}{l}1.20 \\
0.04 \\
1.2 \\
0.00 \\
2.4\end{array}$ \\
\hline \multicolumn{13}{|c|}{ STATISTICS OF MONTHLY MEAN DATA FOR WATER YEARS 1999 - 2004, BY WATER YEAR (WY) } \\
\hline $\begin{array}{l}\text { MEAN } \\
\text { MAX } \\
\text { (WY) } \\
\text { MIN } \\
\text { (WY) }\end{array}$ & $\begin{array}{r}0.70 \\
2.20 \\
(2001) \\
0.00 \\
(2000)\end{array}$ & $\begin{array}{r}0.09 \\
0.21 \\
(2003) \\
0.00 \\
(1999)\end{array}$ & $\begin{array}{r}0.00 \\
0.00 \\
(1999) \\
0.00 \\
(1999)\end{array}$ & $\begin{array}{r}0.00 \\
0.00 \\
(1999) \\
0.00 \\
(1999)\end{array}$ & $\begin{array}{r}0.22 \\
1.10 \\
(2004) \\
0.00 \\
(1999)\end{array}$ & $\begin{array}{r}0.29 \\
1.21 \\
(2003) \\
0.00 \\
(2001)\end{array}$ & $\begin{array}{r}0.59 \\
3.45 \\
(2004) \\
0.00 \\
(2000)\end{array}$ & $\begin{array}{r}0.01 \\
0.03 \\
(2001) \\
0.00 \\
(1999)\end{array}$ & $\begin{array}{r}0.30 \\
0.84 \\
(2004) \\
0.00 \\
(2002)\end{array}$ & $\begin{array}{r}0.49 \\
1.68 \\
(2004) \\
0.01 \\
(2003)\end{array}$ & $\begin{array}{r}1.47 \\
4.35 \\
(1999) \\
0.28 \\
(2003)\end{array}$ & $\begin{array}{r}0.08 \\
0.16 \\
(2003) \\
0.03 \\
(2000)\end{array}$ \\
\hline
\end{tabular}

SUMMARY STATISTICS

ANNUAL TOTAL

ANNUAL MEAN

HIGHEST ANNUAL MEAN

LOWEST ANNUAL MEAN

HIGHEST DAILY MEAN

LOWEST DAILY MEAN

ANNUAL SEVEN-DAY MINIMUM

MAXIMUM PEAK FLOW

MAXIMUM PEAK STAGE

ANNUAL RUNOFF (AC-FT)

10 PERCENT EXCEEDS

50 PERCENT EXCEEDS
90 PERCENT EXCEEDS

a From rating curve extended above $10 \mathrm{ft}^{3} / \mathrm{s}$, on basis of step-backwater analysis, and slope-area measurement.

b From floodmarks.

e Estimated
FOR 2003 CALENDAR YEAR

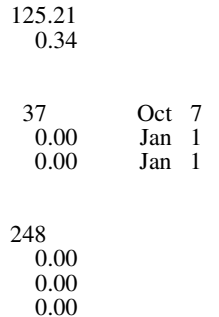

FOR 2004 WATER YEAR

$\begin{array}{ccc}342.78 & & \\ 0.94 & & \\ & & \\ 88 & \text { Apr } & 3 \\ 0.00 & \text { Oct } 1 \\ 0.00 & \text { Oct 12 } \\ 929 & \text { Aug } 4 \\ 6.49 & \text { Aug } & 4 \\ 680 & & \\ 0.00 & & \\ 0.00 & & \\ 0.00 & & \end{array}$

WATER YEARS 1999 - 2004

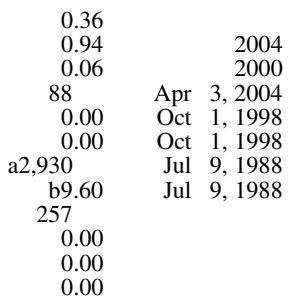




\section{SOUTH DIVERSION CHANNEL ABOVE TIJERAS ARROYO NEAR ALBUQUERQUE, NEW MEXICO}

\section{STATION ANALYSIS}

\section{WATER YEAR 2004}

Equipment.-- An electronic datalogger and pressure transducer, recording on 5-minute intervals, are housed in a concrete block, walk-in shelter on the left bank where the earthen channel upstream becomes entirely concrete lined. The gage is located approximately 0.3 mile downstream from the Murray Road bridge, which is 0.2 miles west of South Broadway Boulevard. An outside staff gage is the reference gage. On April 30, 1999, the lower staff gage was moved to the right bank and a crest-stage gage (CSG) was mounted to the staff support. The lower CSG cap lip elevation is 1.69 feet. A satellite transmitter was installed on May 1, 2003, and updates the USGS web site every 4 hours.

Gage-Height Record.-- The recorder gave a complete and satisfactory record for water year 2004 except for the following periods. Ice formed over the pressure transducer orifice which caused erroneous gage height readings on December 21-29, and 31, 2003, and January 1-7, 2004. Daily mean discharges were estimated for these periods based on precipitation falling in the watershed and base flows prior to and after the affected dyas. During the flow on April 3, 2004, an oil spill occurred approximately 1 mile upstream of the gage. On April 5, AMAFCA maintenance crews constructed an earthen dam immediately downstream of the gage in an effort to contain the spill and assist in cleanup procedures. The earthen dam was washed out by the flow of April 8 , then re-built on approximately April 13. Daily mean discharges were estimated for April 5-6, and 8, however, the flow on April 11 was unaffected. No flows occurred between April 11 and June 29 when the dam was washed out for the final time. The gage-height plot for June 29clearly shows when the embankment was breached, so corrections could be applied with little loss in accuracy. Daily mean discharges were estimated for July 23-24 because the large flow tore the orifice pipe from its concrete anchors. It was repaired on July 27. The instantaneous peak-of year gage height and discharge for July 23 was accurately computed based on excellent high-water marks present near the gage. Prior to May 3 , 1999, only gage heights above 0.11 feet were recorded because the orifice line was mounted on top of the concrete channel bottom. On May 3, 1999, the orifice was mounted on the upstream face of the concrete channel apron and below the Point of Zero Flow (PZF). A 1.00-foot datum was added to recorded gage heights to prevent negative readings during dry periods.

Rating.-- The control for this station is the upstream lip of the concrete-lined trapezoidal channel. The concrete-lined portion of the channel starts at the orifice mount. Upstream from the gage, the channel is an earthen bottom, trapezoidal shape. The bottom width of the channel is 16 feet. The slope of the sides is approximately 35 degrees. The depth of the channel is approximately 18 feet. New ratings 5.0 and 5.1 were developed in water year 2002. They are basically the same as rating 4.0 except the multiple input points used in rating 4.0, which caused an irregular-shaped line, were eliminated in ratings 5.0 and 5.1. The new ratings more closely approximated actual discharge measurements. Rating 
5.1 is the same as 5.0 except that a 1.00 -foot datum is added to all gage heights to prevent negative readings during dry periods. No shift corrections were applied to rating 5.1 this water year because of the stable nature of the channel at the gage and control.

Discharge.--Discharges were computed using rating 5.1 directly, with no shifts, for the entire water year. The channel bottom normally remains clear; therefore, shifts are rarely required at this site.

During water year 2004, 35 site inspections were completed. The maximum instantaneous stage and discharge during this water year occurred on July 23, 2004, and were 6.70 feet and 1,300 cubic feet per second, respectively. 
LOCATION.--Lat 3500'10", long 106³9'26", Bernalillo County, Hydrologic Unit 13020203, on right bank $600 \mathrm{ft}$ upstream from confluence with Tijeras Arroyo, and $2.5 \mathrm{mi}$ south of Albuquerque.

DRAINAGE AREA.--11.0 $\mathrm{mi}^{2}$

PERIOD OF RECORD.--June 1988 to current year.

GAGE.--Water-stage recorder, crest-stage gage, and concrete control. Elevation of gage is 4,930 ft above National Geodetic Vertical Datum of 1929 , from topographic map.

REMARKS.--Records good except for those estimated, which are poor.

DISCHARGE, CUBIC FEET PER SECOND

WATER YEAR OCTOBER 2003 TO SEPTEMBER 2004

\begin{tabular}{|c|c|c|c|c|c|c|c|c|c|c|c|c|}
\hline DAY & OCT & $\mathrm{NOV}$ & DEC & JAN & FEB & MAR & APR & MAY & JUN & JUL & AUG & SEP \\
\hline 1 & 0.00 & 0.07 & 0.56 & $\mathrm{e} 0.30$ & 0.71 & 0.04 & 0.00 & 0.00 & 0.00 & 0.02 & 0.00 & 0.00 \\
\hline 2 & 0.00 & 0.15 & 0.44 & $\mathrm{e} 0.30$ & 0.64 & 0.00 & 2.6 & 0.00 & 0.00 & 0.00 & 0.00 & 0.00 \\
\hline 3 & 0.00 & 0.01 & 0.22 & $\mathrm{e} 0.30$ & 0.43 & 0.48 & 93 & 0.00 & 0.00 & 0.00 & 0.00 & 0.00 \\
\hline 4 & 0.00 & 0.14 & 0.32 & $\mathrm{e} 0.30$ & 0.47 & 19 & 3.4 & 0.00 & 0.00 & 0.00 & 0.00 & 0.00 \\
\hline 5 & 0.22 & 0.26 & 0.19 & $\mathrm{e} 0.30$ & 0.27 & 2.0 & $\mathrm{e} 0.50$ & 0.00 & 0.00 & 0.00 & 0.00 & 0.00 \\
\hline 6 & 0.44 & 0.17 & 0.46 & $\mathrm{e} 0.40$ & 0.00 & 0.42 & $\mathrm{e} 0.00$ & 0.00 & 0.00 & 0.00 & 0.00 & 0.00 \\
\hline 7 & 24 & 0.00 & 0.80 & $\mathrm{e} 0.40$ & 0.00 & 0.03 & 0.00 & 0.00 & 0.00 & 0.00 & 0.00 & 0.00 \\
\hline 8 & 10 & 0.05 & 0.78 & 0.52 & 0.00 & 0.00 & $\mathrm{e} 2.9$ & 0.00 & 0.00 & 0.00 & 0.00 & 0.00 \\
\hline 9 & 0.95 & 0.28 & 0.44 & 0.40 & 0.00 & 0.00 & 0.33 & 0.00 & 0.00 & 0.00 & 0.00 & 0.00 \\
\hline 10 & 3.4 & 0.33 & 0.44 & 0.26 & 0.00 & 0.00 & 1.1 & 0.00 & 0.00 & 0.00 & 0.00 & 0.00 \\
\hline 11 & 3.9 & 0.27 & 0.57 & 0.63 & 0.00 & 0.00 & 1.6 & 0.00 & 0.00 & 0.00 & 0.79 & 0.00 \\
\hline 12 & 0.55 & 0.80 & 0.76 & 0.46 & 0.00 & 0.00 & 0.03 & 0.00 & 0.00 & 1.4 & 0.16 & 0.00 \\
\hline 13 & 0.42 & 7.8 & 0.74 & 0.30 & 0.00 & 0.00 & 0.00 & 0.00 & 0.00 & 3.0 & 0.05 & 0.00 \\
\hline 14 & 0.18 & 0.80 & 0.55 & 0.01 & 0.00 & 0.00 & 0.00 & 0.00 & 0.00 & 0.05 & 0.00 & 0.00 \\
\hline 15 & 0.00 & 0.44 & 0.50 & 0.28 & 0.00 & 0.00 & 0.00 & 0.00 & 0.00 & 2.8 & 0.00 & 0.00 \\
\hline 16 & 0.00 & 0.45 & 0.38 & 0.42 & 0.00 & 0.00 & 0.00 & 0.00 & 0.00 & 4.2 & 0.00 & 0.00 \\
\hline 17 & 0.00 & 0.65 & 0.34 & 0.27 & 0.00 & 0.00 & 0.00 & 0.00 & 0.00 & 0.11 & 0.00 & 0.00 \\
\hline 18 & 0.00 & 0.49 & 0.44 & 0.44 & 0.00 & 0.00 & 0.00 & 0.00 & 0.00 & 0.00 & 0.00 & 0.00 \\
\hline 19 & 0.15 & 0.51 & 0.51 & 0.49 & 0.00 & 0.00 & 0.00 & 0.00 & 0.00 & 0.04 & 0.00 & 19 \\
\hline 20 & 0.27 & 0.36 & 0.30 & 0.44 & 0.00 & 0.00 & 0.00 & 0.00 & 0.00 & 0.17 & 0.00 & 10 \\
\hline 21 & 0.18 & 0.06 & $\mathrm{e} 0.30$ & 0.77 & 0.00 & 0.07 & 0.00 & 0.00 & 0.00 & 0.18 & 0.00 & 0.35 \\
\hline 22 & 0.21 & 0.00 & $\mathrm{e} 0.30$ & 0.53 & 0.20 & 0.13 & 0.00 & 0.00 & 0.00 & 5.5 & 0.00 & 0.00 \\
\hline 23 & 0.23 & 0.37 & $\mathrm{e} 0.30$ & 0.46 & 12 & 0.00 & 0.00 & 0.00 & 0.00 & e230 & 0.00 & 0.00 \\
\hline 24 & 0.17 & 0.62 & $\mathrm{e} 0.30$ & 0.51 & 17 & 0.49 & 0.00 & 0.00 & 0.00 & $\mathrm{e} 70$ & 0.00 & 0.00 \\
\hline 25 & 0.00 & 0.56 & $\mathrm{e} 0.30$ & 0.73 & 0.63 & 0.08 & 0.00 & 0.00 & 0.00 & 0.00 & 0.00 & 0.00 \\
\hline 26 & 0.24 & 0.42 & $\mathrm{e} 0.30$ & 0.69 & 0.08 & 0.00 & 0.00 & 0.00 & 0.00 & 0.00 & 0.00 & 0.00 \\
\hline 27 & 0.37 & 0.47 & $\mathrm{e} 0.30$ & 0.41 & 0.00 & 0.00 & 0.00 & 0.00 & 0.00 & 0.00 & 0.00 & 0.00 \\
\hline 28 & 0.49 & 0.60 & $\mathrm{e} 0.30$ & 0.47 & 0.50 & 0.00 & 0.00 & 0.00 & 0.00 & 2.1 & 0.00 & 0.00 \\
\hline 29 & 0.94 & 0.71 & $\mathrm{e} 0.30$ & 0.33 & 0.56 & 0.00 & 0.00 & 0.00 & 14 & 0.12 & 0.00 & 0.00 \\
\hline 30 & 0.29 & 0.73 & 0.37 & 0.38 & --- & 0.00 & 0.00 & 0.00 & 0.59 & 0.00 & 0.00 & 0.00 \\
\hline 31 & 0.01 & -- & $\mathrm{e} 0.30$ & 0.54 & --- & 0.00 & --- & 0.00 & --- & 0.00 & 0.00 & --- \\
\hline OTAL & 47.61 & 18.57 & 13.11 & 13.04 & 33.49 & 22.74 & 105.46 & 0.00 & 14.59 & 319.69 & 1.00 & 29.35 \\
\hline IEAN & 1.54 & 0.62 & 0.42 & 0.42 & 1.15 & 0.73 & 3.52 & 0.00 & 0.49 & 10.3 & 0.03 & 0.98 \\
\hline IAX & 24 & 7.8 & 0.80 & 0.77 & 17 & 19 & 93 & 0.00 & 14 & 230 & 0.79 & 19 \\
\hline IIN & 0.00 & 0.00 & 0.19 & 0.01 & 0.00 & 0.00 & 0.00 & 0.00 & 0.00 & 0.00 & 0.00 & 0.00 \\
\hline C-FT & 94 & 37 & 26 & 26 & 66 & 45 & 209 & 0.00 & 29 & 634 & 2.0 & 58 \\
\hline
\end{tabular}

STATISTICS OF MONTHLY MEAN DATA FOR WATER YEARS 1994 - 2004, BY WATER YEAR (WY)

\begin{tabular}{|c|c|c|c|c|c|c|c|c|c|c|c|c|}
\hline MEAN & 0.95 & 0.73 & 0.10 & 0.09 & 0.22 & 0.39 & 0.42 & 0.21 & 0.47 & 1.57 & 1.29 & 0.83 \\
\hline MAX & 2.88 & 4.50 & 0.42 & 0.42 & 1.15 & 1.56 & 3.52 & 1.83 & 3.14 & 10.3 & 4.65 & 2.79 \\
\hline (WY) & (1995) & (1995) & (2004) & (2004) & (2004) & (2003) & (2004) & (1994) & (1996) & (2004) & (1994) & (1997) \\
\hline MIN & 0.00 & 0.00 & 0.00 & 0.00 & 0.00 & 0.00 & 0.00 & 0.00 & 0.00 & 0.04 & 0.03 & 0.00 \\
\hline (WY) & (2002) & (1996) & (1994) & (1994) & (1996) & (1996) & (1994) & (1995) & (1995) & (2002) & (2004) & (1998) \\
\hline
\end{tabular}

\section{SUMMARY STATISTICS}

ANNUAL TOTAL

ANNUAL MEAN

HIGHEST ANNUAL MEAN

LOWEST ANNUAL MEAN

HIGHEST DAILY MEAN

LOWEST DAILY MEAN

ANNUAL SEVEN-DAY MINIMUM

MAXIMUM PEAK FLOW

MAXIMUM PEAK STAGE

ANNUAL RUNOFF (AC-FT)

10 PERCENT EXCEEDS

90 PERCENT EXCEEDS
FOR 2003 CALENDAR YEAR

$\begin{array}{rr}158.29 & \\ 0.43 & \\ & \\ 24 & \text { Mar 21 } \\ 0.00 & \text { Jan } 1 \\ 0.00 & \text { Jan } 1 \\ & \\ & \\ 314 & \\ 0.61 & \\ 0.00 & \\ 0.00 & \end{array}$

FOR 2004 WATER YEAR

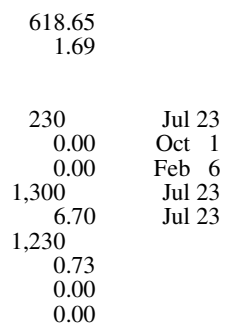

WATER YEARS 1994 - 2004

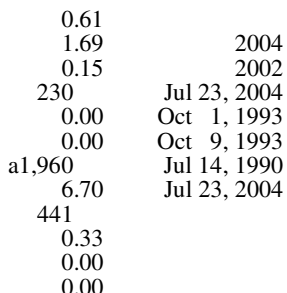

a From rating curve extended above $30 \mathrm{ft}^{3} / \mathrm{s}$, on basis of step-backwater analysis.

e Estimated 


\section{AMOLE DEL NORTE CHANNEL AT ALBUQUERQUE, NEW MEXICO}

\section{WATER YEAR 2004}

Equipment.--. An electronic datalogger and pressure transducer, recording on 5-minute intervals, are housed in a metal, 2.5- by 2.5- by 6-foot shelter on the right bank of the concrete-lined channel, approximately 100 feet south of the Blake Road bridge. The site is approximately 0.5 mile west of Coors Boulevard on Albuquerque's southwest side. The 30-foot orifice line is housed in a 3/4-inch-diameter galvanized pipe anchored to the side wall of the channel. A concrete, broad-crested weir 980 feet downstream from the gage is the control. The top of the control wall is 1.0 foot higher than the elevation of the channel bottom at the gage because the channel slope is a very flat 0.0007 foot per foot. Because of this gentle slope, sediment accumulates in the channel bottom at the gage. An outside staff gage is painted on the channel side slope for reference. The point of zero flow (PZF) is referenced to a hex-head lag bolt anchored in the channel bottom outlined by a chiseled square. The PZF elevation is 1.00 foot. A crest-stage gage is mounted to the right channel sidewall and is inclined 26.5 degrees from horizontal. The elevation of the crest-stage gage cap is 2.14 feet referenced to the PZF. Low-water wading measurements are made in the vicinity of the gage.

Gage-Height Record.-- The water-stage recorder, referenced to the PZF bolt in the bottom of the channel or the outside staff gage, gave a complete and satisfactory record during water year 2004. Substantial rainfall is necessary to produce runoff at this site. No other gage exists on this particular channel, therefore, no hydrographic comparisons are possible.

The recorder senses only water levels greater than 0.30 foot deep ( 1.30 -foot recorded gage height) because the orifice pipe is mounted 0.30 foot above the channel bottom to prevent siltation problems. At a gage height of $1.31 \mathrm{feet}$, the computed discharge is 0.17 cubic feet per second.

Rating.--The channel is concrete lined and trapezoidal shape at the gage, but the gage pool is controlled by a 40 -foot-wide, broad-crested concrete weir 980 feet downstream. A onefoot-wide notch is cut into the weir wall and is the low-flow control. The channel is straight for at least 1,000 feet upstream and 980 feet downstream from the gage. A theoretical rating was_developed using a step-backwater analysis and the U.S. Geological Survey Water Surface Profile (WSPRO) software. This site was measured for the first time in water year 2001, which better defined the low end of the rating. Measurements are difficult to obtain because of the flashy nature of this channel. All four measurements in water year 2001 plotted significantly left of theoretical rating 1.0, so a new rating, 2.0, was developed in water year 2001. The new rating breaks to the right at a gage height of approximately 2.12 feet, or the level at which broad-crested weir flow begins. The new rating curve gradually blends into the old theoretical rating by a stage of 9.38 feet.

One measurement, number 5, was completed in water year 2002. It plotted within 1.4 percent of rating 2.0. Because the channel is concrete lined and the control weir was clear 
at the time of this measurement, no shift was needed. Three additional measurements (12-14) were completed in water year 2004 during identical, free-flowing control conditions and all plot within 7 percent of rating 2.0, further varifying the stage-discharge relationship. The small measurement variation from the rating curve is due to inherent errors in the measuring process.

The weir control is subject to debris accumulations, which affect the low flow rating if the 1foot notch in the control wall is obstructed. Two shifts were applied in water year 2004 because the low-flow notch of the weir was obstructed with debris. Measurements (\#6-8) completed on October 22, 2002, represent the condition when debris partially blocks the low-flow notch and affects stage readings at the gage. These 3 measurements defined a single average shift curve to rating 2.0 with a base shift value of negative 0.10 foot. An assumption is made that this effective shift value is approximately the same whenever the low-flow weir notch is partially obstucted. Field personnel identified this type of control condition for the period July 22-24, 2004 , however no discharge measurements were completed, so the -0.10 -foot shift was applied for this period based on the October 2002 measurements.

Measurements 9 and 10 were completed February 13, 2003, when the low-flow notch was completely blocked by debris. Both measurements defined an average shift of -0.30 foot to rating 2.0. In water year 2004, measurement 11 occurred during the same, fully-blocked control condition and a negative 0.29 -foot shift was computed. These 3 measurements are the basis for the assumption that, if no discharge measurements are available, a -0.30-foot shift is applied when a fully-blocked control condition occurs.

Discharge.-- Rating 2.0 was applied directly without shifts at the end of water year 2003 and into water year 2004 (until February 23) because the control weir remained clear of debris. Field inspections noted full blockage of the low-flow weir notch immediately after the flow on February 23, 2004. This condition remained during measurement 11 on March 4, which defined a negative 0.29-foot shift. The channel and control were cleared on April 3, 2004, immediately before measurements 12-14 were completed. The debris causing the -0.29-foot shift washed in during the flow on February 23, so it was prorated from zero as gage heights rose. The shift remained - 0.29 foot until April 3 when the control was cleared. The field inspection on July 24 described a partially obstructed low-flow control. As noted in the "Rating" paragraph above, since no measurements were possible, a -0.10-foot shift is applied under these conditions. This shift value was prorated on during the rise of the large flow on July 22 and removed when the debris was cleared on July 24. Field inspections between July 24 and October 12, 2004 confirmed that the weir remained clear, so no shifts were necessary.

During water year 2004, 22 site inspections and 4 measurement were completed. The instantaneous peak stage and discharge for water year 2004 were 4.29 feet and 259 cubic feet per second, respectively, on July 22, 2004.

Remarks.-- No flows will occur until significant precipitation falls in the watershed. No other gages exist in this watershed for comparison purposes, so precipitation records are the only source available to estimate discharges at this site. The record in water year 2004 is good. 
LOCATION.--Lat 3502'14", long 106 43'15", Bernalillo County, Hydrologic Unit 13020203, in Atrisco Grant, on right bank of concrete-lined channel 100 ft south of Blake Road and 2,500 ft west of intersection of Blake Road and Coors Blvd. in southwest Albuquerque.

DRAINAGE AREA.--6.302 $\mathrm{mi}^{2}$.

PERIOD OF RECORD.--April 2000 to current year.

GAGE.--Water-stage recorder and crest-stage gage. Elevation of gage is 4,997 ft above National Geodetic Vertical Datum of 1929 , from topographic map. REMARKS.--Records good.

DISCHARGE, CUBIC FEET PER SECOND

WATER YEAR OCTOBER 2003 TO SEPTEMBER 2004

\begin{tabular}{|c|c|c|c|}
\hline DAY & OCT & NOV & DEC \\
\hline $\begin{array}{l}1 \\
2 \\
3 \\
4 \\
5\end{array}$ & $\begin{array}{l}0.00 \\
0.00 \\
0.00 \\
0.00 \\
0.00\end{array}$ & $\begin{array}{l}0.00 \\
0.00 \\
0.00 \\
0.00 \\
0.00\end{array}$ & $\begin{array}{l}0.00 \\
0.00 \\
0.00 \\
0.00 \\
0.00\end{array}$ \\
\hline $\begin{array}{r}6 \\
7 \\
8 \\
9 \\
10\end{array}$ & $\begin{array}{l}0.00 \\
3.4 \\
1.2 \\
0.00 \\
2.6\end{array}$ & $\begin{array}{l}0.00 \\
0.00 \\
0.00 \\
0.00 \\
0.00\end{array}$ & $\begin{array}{l}0.00 \\
0.00 \\
0.00 \\
0.00 \\
0.00\end{array}$ \\
\hline $\begin{array}{l}11 \\
12 \\
13 \\
14 \\
15\end{array}$ & $\begin{array}{l}3.2 \\
0.61 \\
0.00 \\
0.00 \\
0.00\end{array}$ & $\begin{array}{l}0.00 \\
1.7 \\
0.84 \\
0.00 \\
0.00\end{array}$ & $\begin{array}{l}0.00 \\
0.00 \\
0.00 \\
0.00 \\
0.00\end{array}$ \\
\hline $\begin{array}{l}16 \\
17 \\
18 \\
19 \\
20\end{array}$ & $\begin{array}{l}0.00 \\
0.00 \\
0.00 \\
0.00 \\
0.00\end{array}$ & $\begin{array}{l}0.00 \\
0.00 \\
0.00 \\
0.00 \\
0.00\end{array}$ & $\begin{array}{l}0.00 \\
0.00 \\
0.00 \\
0.00 \\
0.00\end{array}$ \\
\hline $\begin{array}{l}21 \\
22 \\
23 \\
24 \\
25\end{array}$ & $\begin{array}{l}0.00 \\
0.00 \\
0.00 \\
0.00 \\
0.00\end{array}$ & $\begin{array}{l}0.00 \\
0.00 \\
0.00 \\
0.00 \\
0.00\end{array}$ & $\begin{array}{l}0.00 \\
0.00 \\
0.00 \\
0.00 \\
0.00\end{array}$ \\
\hline $\begin{array}{l}26 \\
27 \\
28 \\
29 \\
30 \\
31\end{array}$ & $\begin{array}{l}0.00 \\
0.00 \\
0.00 \\
0.00 \\
0.00 \\
0.00\end{array}$ & $\begin{array}{c}0.00 \\
0.00 \\
0.00 \\
0.00 \\
0.00 \\
---\end{array}$ & $\begin{array}{l}0.00 \\
0.00 \\
0.00 \\
0.00 \\
0.00 \\
0.00\end{array}$ \\
\hline $\begin{array}{l}\text { TOTAL } \\
\text { MEAN } \\
\text { MAX } \\
\text { MIN } \\
\text { AC-FT }\end{array}$ & $\begin{array}{c}11.01 \\
0.36 \\
3.4 \\
0.00 \\
22\end{array}$ & $\begin{array}{l}2.54 \\
0.08 \\
1.7 \\
0.00 \\
5.0\end{array}$ & $\begin{array}{l}0.00 \\
0.00 \\
0.00 \\
0.00 \\
0.00\end{array}$ \\
\hline
\end{tabular}

\section{DAILY MEAN VALUES}

\begin{tabular}{|c|c|c|c|c|c|c|c|c|}
\hline JAN & FEB & MAR & APR & MAY & JUN & JUL & AUG & SEP \\
\hline 0.00 & 0.00 & 0.00 & 0.00 & 0.00 & 0.00 & 0.00 & 0.00 & 0.00 \\
\hline 0.00 & 0.00 & 0.01 & 3.6 & 0.00 & 0.00 & 0.00 & 0.28 & 0.00 \\
\hline 0.00 & 0.00 & 0.00 & 27 & 0.00 & 0.08 & 0.00 & 0.00 & 0.00 \\
\hline 0.00 & 0.00 & 5.2 & 2.1 & 0.00 & 0.00 & 0.00 & 0.00 & 0.22 \\
\hline 0.00 & 0.00 & 0.00 & 0.00 & 0.00 & 0.00 & 0.00 & 0.00 & 0.00 \\
\hline 0.00 & 0.00 & 0.00 & 0.00 & 0.00 & 0.00 & 0.00 & 0.00 & 0.00 \\
\hline 0.00 & 0.00 & 0.00 & 0.00 & 0.00 & 0.00 & 0.00 & 0.00 & 0.00 \\
\hline 0.00 & 0.00 & 0.00 & 1.1 & 0.00 & 0.00 & 0.00 & 0.00 & 0.00 \\
\hline 0.00 & 0.00 & 0.00 & 0.00 & 0.00 & 0.00 & 0.00 & 0.00 & 0.00 \\
\hline 0.00 & 0.00 & 0.00 & 1.3 & 0.00 & 0.00 & 0.00 & 1.1 & 0.00 \\
\hline 0.00 & 0.00 & 0.00 & 0.03 & 0.00 & 0.00 & 0.00 & 0.00 & 0.00 \\
\hline 0.00 & 0.00 & 0.00 & 0.00 & 0.00 & 0.00 & 0.96 & 0.00 & 0.00 \\
\hline 0.00 & 0.00 & 0.00 & 0.00 & 0.00 & 0.06 & 0.00 & 0.00 & 0.00 \\
\hline 0.00 & 0.00 & 0.00 & 0.00 & 0.00 & 0.00 & 0.00 & 0.00 & 0.00 \\
\hline 0.00 & 0.00 & 0.00 & 0.00 & 0.00 & 0.00 & 1.2 & 0.14 & 0.00 \\
\hline 0.00 & 0.00 & 0.00 & 0.00 & 0.00 & 0.00 & 0.05 & 0.00 & 0.00 \\
\hline 0.00 & 0.00 & 0.00 & 0.00 & 0.00 & 0.00 & 0.00 & 0.00 & 0.00 \\
\hline 0.00 & 0.00 & 0.00 & 0.00 & 0.00 & 0.00 & 0.01 & 0.00 & 0.17 \\
\hline 0.00 & 0.00 & 0.00 & 0.00 & 0.00 & 0.00 & 0.00 & 0.03 & 2.5 \\
\hline 0.00 & 0.00 & 0.00 & 0.00 & 0.00 & 0.00 & 0.15 & 0.02 & 0.23 \\
\hline 0.00 & 0.00 & 0.00 & 0.00 & 0.00 & 0.00 & 0.16 & 0.00 & 0.00 \\
\hline 0.00 & 0.00 & 0.00 & 0.00 & 0.00 & 0.00 & 9.5 & 0.00 & 0.00 \\
\hline 0.00 & 2.7 & 0.00 & 0.00 & 0.00 & 0.00 & 1.6 & 0.00 & 0.00 \\
\hline 0.00 & 1.3 & 0.00 & 0.00 & 0.00 & 0.00 & 2.5 & 0.00 & 0.00 \\
\hline 0.00 & 0.00 & 0.00 & 0.00 & 0.00 & 0.00 & 16 & 0.00 & 0.00 \\
\hline 0.00 & 0.00 & 0.00 & 0.00 & 0.00 & 0.00 & 0.84 & 0.00 & 0.00 \\
\hline 0.00 & 0.00 & 0.00 & 0.00 & 0.00 & 0.00 & 0.17 & 0.00 & 0.00 \\
\hline 0.00 & 0.00 & 0.00 & 0.00 & 0.00 & 0.00 & 0.01 & 0.00 & 0.00 \\
\hline 0.00 & 0.00 & 0.00 & 0.00 & 0.00 & 2.0 & 0.00 & 0.09 & 0.00 \\
\hline 0.00 & --- & 0.00 & 0.00 & 0.00 & 0.00 & 0.01 & 0.00 & 0.00 \\
\hline 0.00 & --- & 0.00 & --- & 0.00 & --- & 0.00 & 0.00 & --- \\
\hline 0.00 & 4.00 & 5.21 & 35.13 & 0.00 & 2.14 & 33.16 & 1.66 & 3.12 \\
\hline 0.00 & 0.14 & 0.17 & 1.17 & 0.00 & 0.07 & 1.07 & 0.05 & 0.10 \\
\hline 0.00 & 2.7 & 5.2 & 27 & 0.00 & 2.0 & 16 & 1.1 & 2.5 \\
\hline 0.00 & 0.00 & 0.00 & 0.00 & 0.00 & 0.00 & 0.00 & 0.00 & 0.00 \\
\hline 0.00 & 7.9 & 10 & 70 & 0.00 & 4.2 & 66 & 3.3 & 6.2 \\
\hline
\end{tabular}

STATISTICS OF MONTHLY MEAN DATA FOR WATER YEARS 2000 - 2004, BY WATER YEAR (WY)

\begin{tabular}{|c|c|c|c|c|c|c|c|c|c|c|c|c|}
\hline MEAN & 0.31 & 0.19 & 0.02 & 0.06 & 0.05 & 0.13 & 0.32 & 0.11 & 0.09 & 0.57 & 0.24 & 0.15 \\
\hline MAX & 0.76 & 0.50 & 0.03 & 0.23 & 0.14 & 0.23 & 1.17 & 0.38 & 0.35 & 1.07 & 0.75 & 0.53 \\
\hline (WY) & (2001) & (2001) & (2001) & (2001) & (2004) & (2003) & (2004) & $(2000)$ & (2000) & (2004) & (2002) & (2002) \\
\hline MIN & 0.01 & 0.08 & 0.00 & 0.00 & 0.00 & 0.00 & 0.00 & 0.00 & 0.00 & 0.10 & 0.05 & 0.00 \\
\hline (WY) & (2002) & (2004) & (2004) & (2003) & (2001) & (2002) & (2003) & (2003) & (2003) & (2002) & (2004) & (2000) \\
\hline
\end{tabular}

SUMMARY STATISTICS

ANNUAL TOTAL

ANNUAL MEAN

HIGHEST ANNUAL MEAN

LOWEST ANNUAL MEAN

HIGHEST DAILY MEAN

LOWEST DAILY MEAN

ANNUAL SEVEN-DAY MINIMUM

MAXIMUM PEAK FLOW

MAXIMUM PEAK STAGE

10 PERCENT EXCEEDS

50 PERCENT EXCEEDS

90 PERCENT EXCEEDS
FOR 2003 CALENDAR YEAR

$\begin{array}{cc}46.79 & \\ 0.13 & \\ & \\ 18 & \text { Jul 20 } \\ 0.00 & \text { Jan } 1 \\ 0.00 & \text { Jan } 1 \\ & \\ 93 & \\ 0.00 & \\ 0.00 & \\ 0.00 & \end{array}$

FOR 2004 WATER YEAR

$\begin{array}{cc}97.97 & \\ 0.27 & \\ & \\ 27 & \text { Apr 3 } \\ 0.00 & \text { Oct 1 } \\ 0.00 & \text { Oct 13 } \\ 259 & \text { Jul 22 } \\ 4.29 & \text { Jul 22 } \\ 194 & \\ 0.05 & \\ 0.00 & \\ 0.00 & \end{array}$

WATER YEARS 2000 - 2004

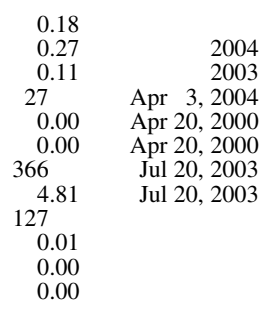




\title{
RAINFALL DATA SUMMARY,
}

\author{
WATER YEAR 2004 \\ (arranged alphabetically)
}




\section{Precipitation for Water Year 2004}

The following section presents daily precipitation totals for the 40 rain gages in the Urban Runoff Program. A station analysis, which lists detailed location descriptions, equipment, and period of data record, is also included for each rain-gage location. In addition, the station analysis describes data problems and how data estimates were made.

\section{Precipitation Totals For Water Year 2004}

During water year 2004, 39 rain gages were operated continuously over the entire year; the Rio Rancho Well \#13 (site ID 50 in table 1) rain gage was not established until August 2004. Averaged over the 39 rain gages that were operated continuously in the metropolitan area, approximately 13.1 inches of rain fell over Albuquerque during water year 2004. However, the variation in both spatial and temporal distribution of rainfall in the Albuquerque area is large. For example, the rain gage at Bear Canyon (site ID 1) in the Sandia foothills measured more than 19 inches of rain for water year 2004, while the rain gage at Tijeras Arroyo (site ID 25), located approximately 12 miles southwest of the rain gage at Bear Canyon, measured less than 10 inches of rain for water year 2004.

The variation in spatial distribution of annual precipitation over the USGS rain-gage network is illustrated in figure 4, which shows water year 2004 precipitation totals for 39 of the USGS rain gages. The rain gage at Well \#13 near Rio Rancho (site ID 50 in table 1) is not included in the figure because it did not have a complete data record for water year 2004. Additionally, annual precipitation totals from the Walker Pump Station (site ID 10), Kirtland Air Force Base (site ID 14), North Camino Arroyo (site ID 18), North Floodway near Alameda (site ID 26), San Jose Drain (site ID 33), Albuquerque City Hall (site ID 34), Taylor Ranch Drain (site ID 37), and Swinburn Dam (side ID 38) rain gages include days with estimated daily totals; details about data estimates are given in the station analysis.

The combined precipitation for July through September for water year 2004 is also shown in figure 4. In general, a disproportionate amount of total annual precipitation in Albuquerque falls in July through September due to the onset of the southwestern monsoon, during which moisture-laden air is drawn into Mexico and the southwestern United States from the Gulf of California and the Gulf of Mexico (Adams and Comrie, 1997). During water year 2004, the average monthly precipitation for July through September was 1.45 inches, while the average monthly precipitation for October through June was 0.97 inches.

The station locations shown in figure 4 are listed, from left to right, in order of increasing longitude. Although not readily apparent in figure 4, there is a slight increasing total precipitation trend in an eastward direction, or towards the Sandia Mountains. This precipitation trend, although modest, is not surprising because the increasing elevation forces an increase in convection and consequently creates more uplift of water vapor to the condensation level.

\section{Comparison to Historical Data}

Due to the large variation in precipitation distribution across the metropolitan area, using an annual average of the entire rain-gage network to determine if water year 2004 was a "wet" or 


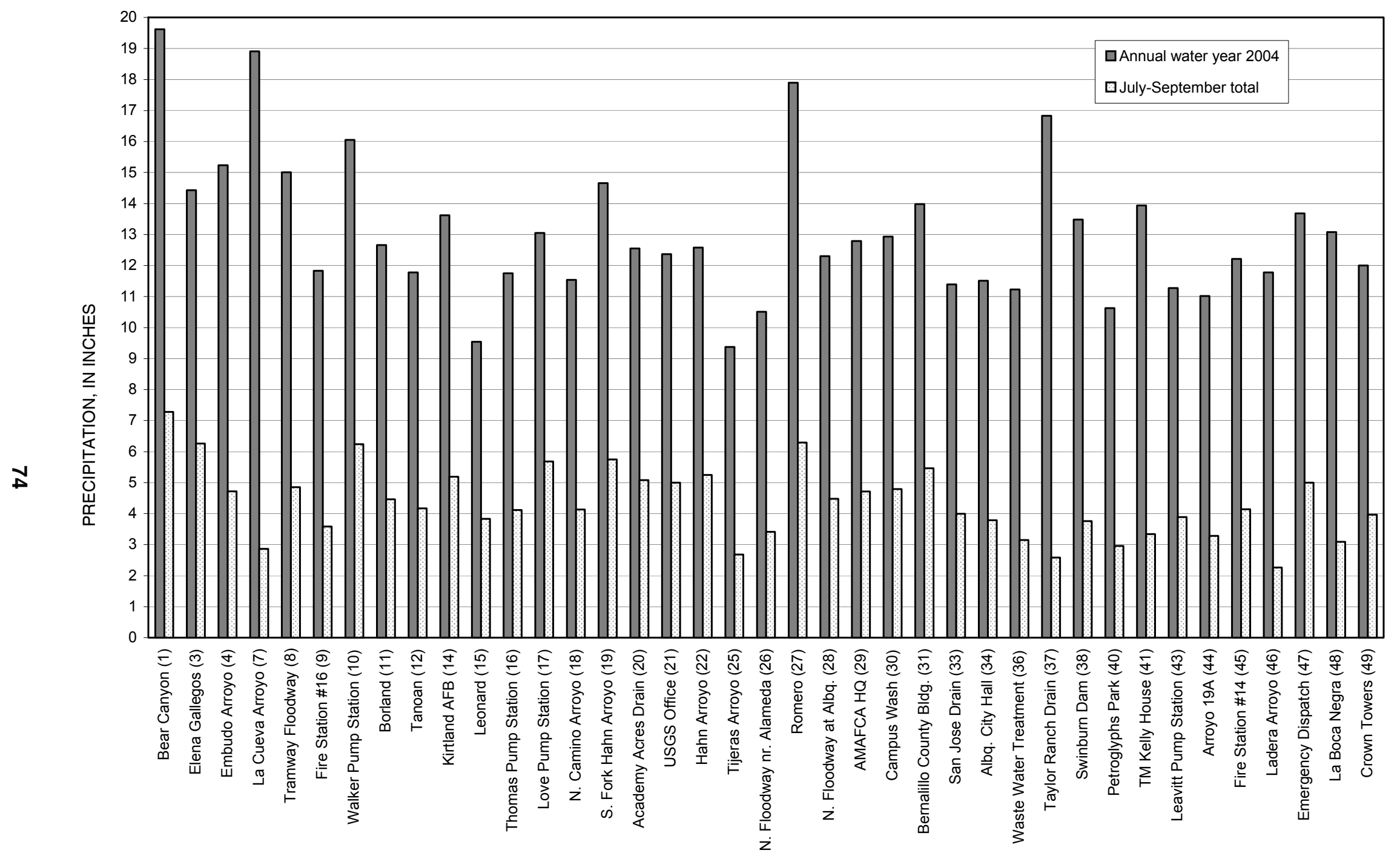

Figure 4. Precipitation totals for water year 2004 in comparison to totals for July through September 2004 at 39 U.S. Geological Survey rain gages. The gages are listed by name and site ID number from table 1. 
dry"year is less than ideal. Instead, it is more meaningful to compare water year 2004 precipitation data with historical precipitation data sampled over the same spatial and temporal scales. For this reason, seven rain gages in the USGS network were selected to give a good geographic representation of the 40 rain gages in the Albuquerque metropolitan area: Bear Canyon Arroyo (site ID 1) in the Sandia Mountains foothills, Leonard (site ID 15) in northeast Albuquerque, North Camino Arroyo Tributary(site ID 18) in the far northeast heights, Tijeras Arroyo (site ID 25 ) in southern Albuquerque, City Hall (site ID 34) in central Albuquerque, Taylor Ranch Drain (site ID 37) in the northwest, and Fire Station 14 (site ID 45) in southwestern Albuquerque.

Figure 5 compares total annual precipitation for water year 2004 to average historical total annual precipitation at each of the selected seven rain gages. With the exception of the North Camino Arroyo rain gage, the remaining six selected rain gages averaged about 30 percent above average precipitation for water year 2004; the North Camino rain gage recorded about 30 percent below average precipitation for the water year.

Precipitation during water year 2004 for the seven selected rain gages is also compared to historical precipitation on a monthly basis. Figures 6-9 show total monthly precipitation, for both water year 2004 and for each water year in the historical USGS precipitation record, and the average historical monthly precipitation at each of the seven selected rain gages. Data point symbols in these figures are centered over their corresponding values. Also, because the data record from these selected stations varies from less than 10 years to over 20 years of historical data, the number of historical data points for each gage varies accordingly.

Generally, monthly totals for water year 2004 at these seven selected rain gages were above corresponding historical averages. Specifically, February 2004 and April 2004 were exceptionally wet months in the Albuquerque metropolitan area, during which all seven selected rain gages recorded above-average precipitation totals. In fact, both February and April were period-of-record monthly maximums for the Bear Canyon, Tijeras, Albuquerque City Hall and Taylor Ranch rain gages; February was also a period-of-record monthly maximum at the Fire Station \#14 rain gage. In contrast, although May is typically a very dry month in Albuquerque, May 2004 was an exceptionally dry month; none of the seven selected rain gages recorded precipitation during this month and only 0.06 inch of precipitation was recorded across the entire network of USGS rain gages that were operational during May.

Finally, precipitation during the monsoonal months of July, August, and September was about normal; the mean total precipitation measured at the seven selected rain gages during these three months was $98 \%$ of the corresponding historical 3-month average. Although precipitation during the month of July was well above the historical monthly average at each of the selected rain gages, precipitation during the month of August was conversely well below the historical monthly average at every selected rain gage except Bear Canyon Arroyo. Combined with nearly average September precipitation at each of the selected rain gages, the wet July countered by a dry August resulted in very near normal monsoonal precipitation during water year 2004.

\section{REFERENCES CITED}

Adams, D.K., and A.C. Comrie, 1997: The North American monsoon. Bull. Amer. Meteor. Soc., 78, 2197-2213. 


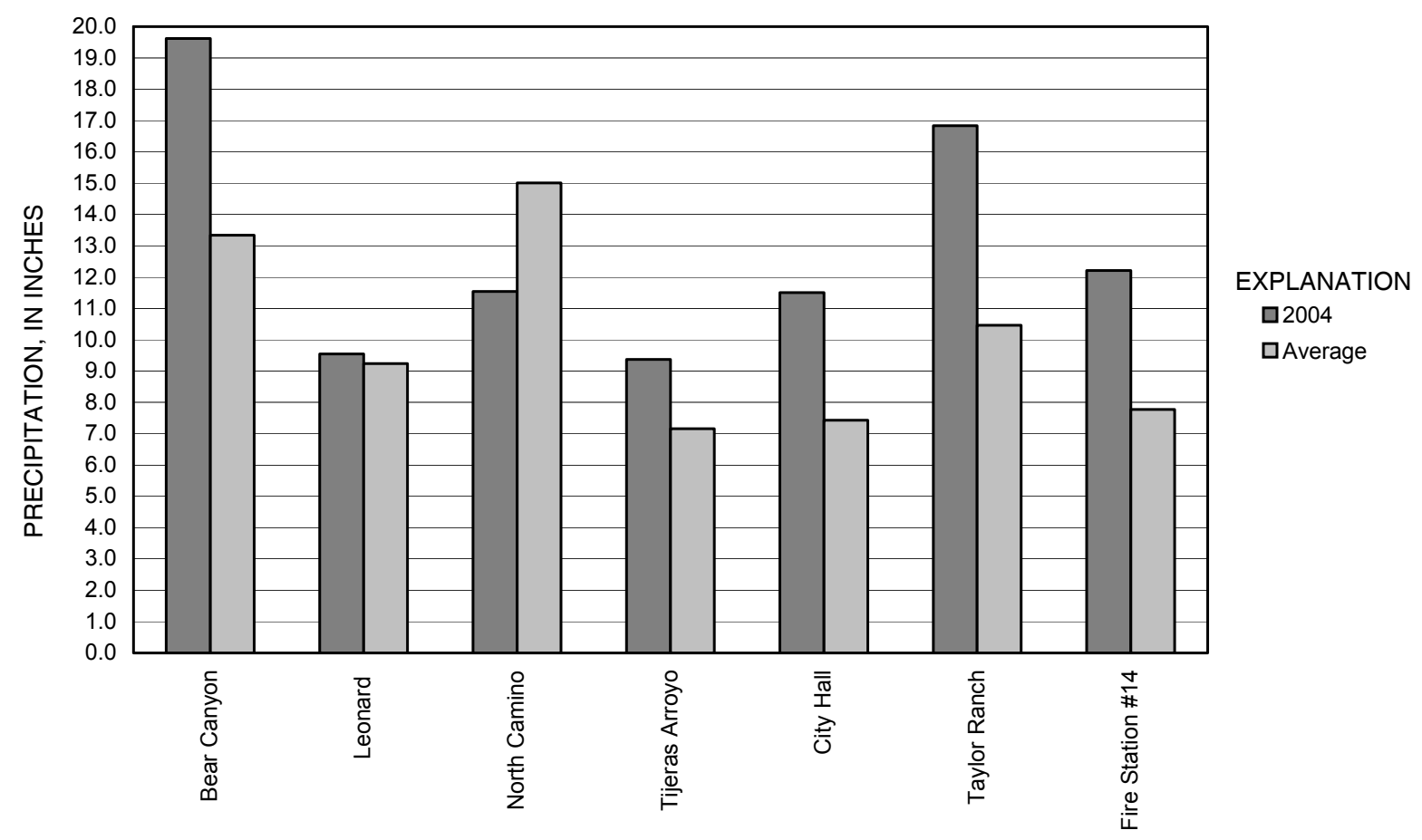

Figure 5. Comparison of total annual precipitation for water year 2004 to average historical total annual precipitation at selected U.S. Geological Survey rain-gage sites. Location of gages in figure 1.

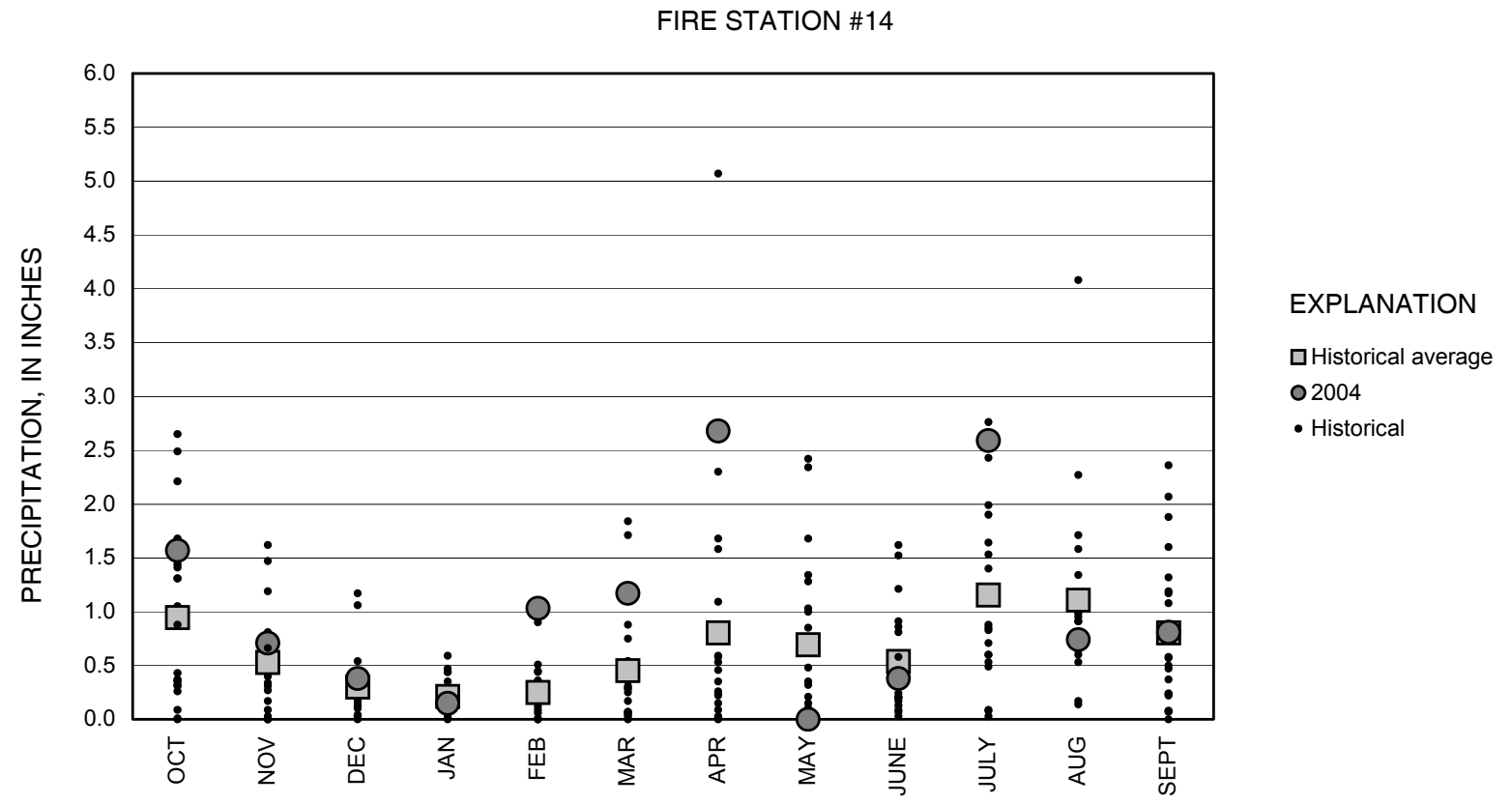

Figure 6. Monthly precipitation at the Fire Station \#14 rain-gage site. Location of gage in figure 1. 

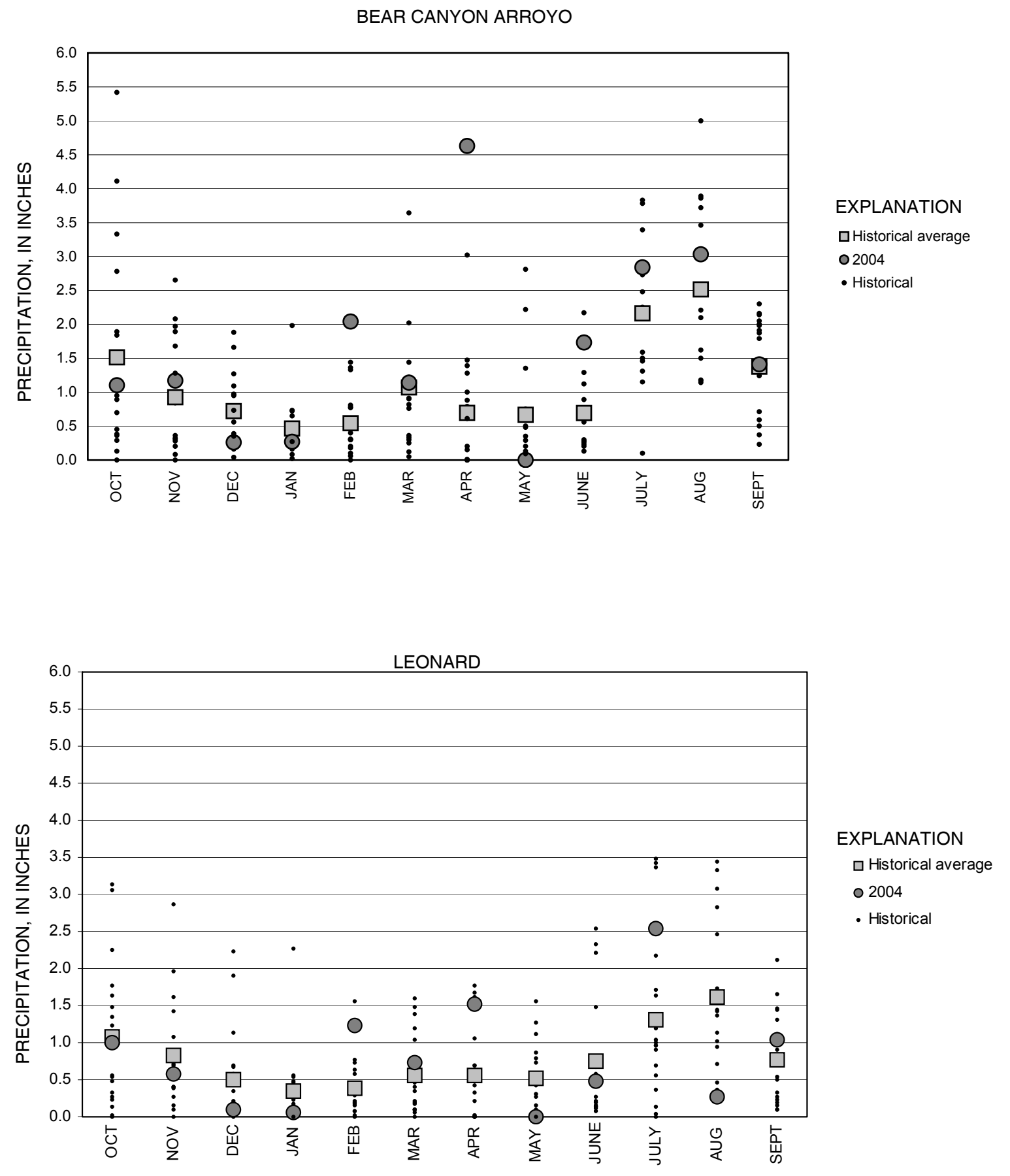

Figure 7. Monthly precipitation at selected U.S. Geological Survey rain-gage sites. Location of gages in figure 1 . 

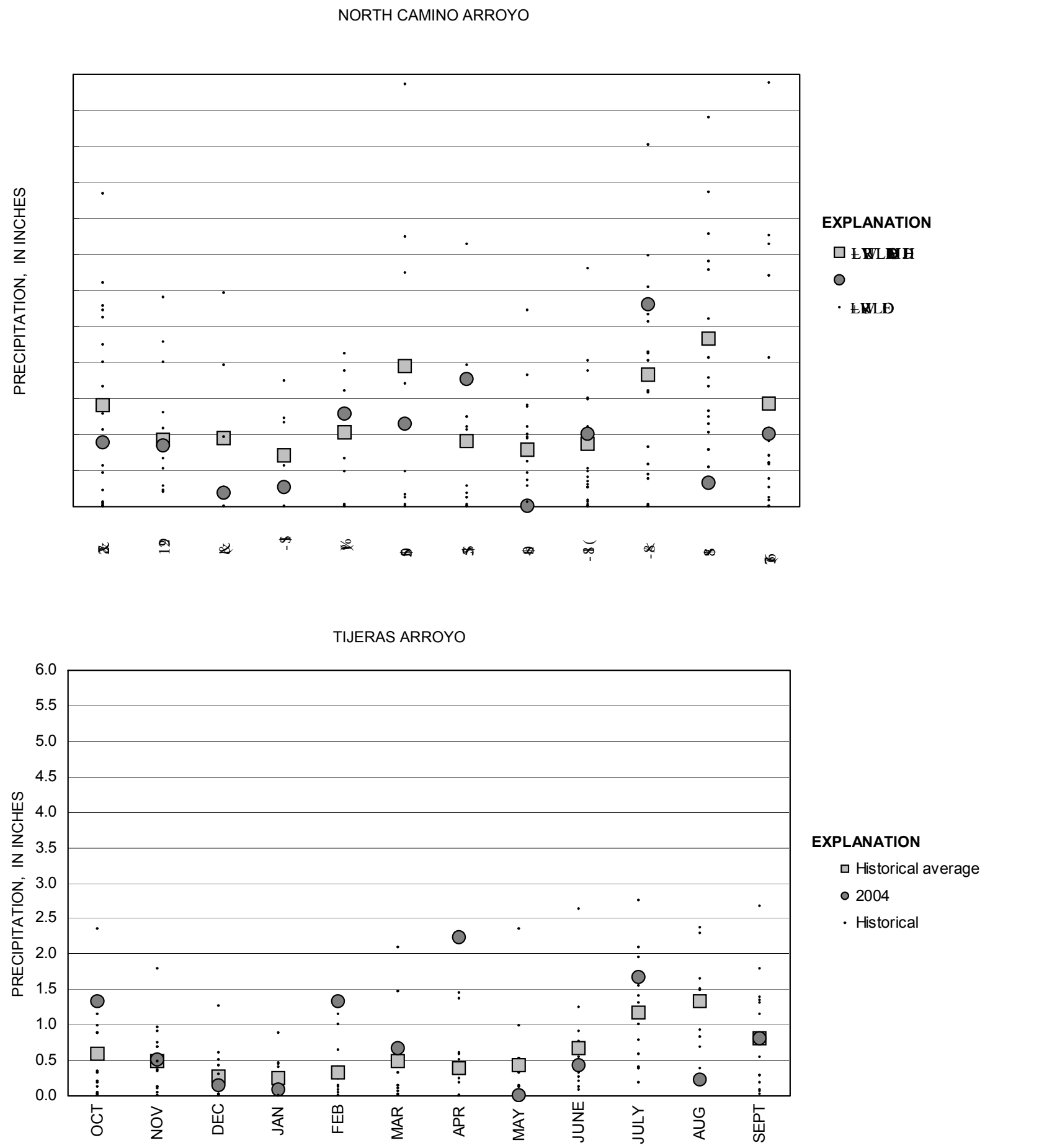

Figure 8. Monthly precipitation at selected U.S. Geological Survey rain-gage sites. Location of gages in figure 1 . 


\section{ACADEMY ACRES DRAIN RAIN GAGE AT ALBUQUERQUE, NEW MEXICO STATION ANALYSIS \\ WATER YEAR 2004}

Location.--3509'04'N, 106 34'23”W. Rain gage is located in northeast Albuquerque on Burlison Drive, approximately 0.5 mile north of intersection with Academy Road, approximately 1 mile east of San Mateo Boulevard.

Equipment.--Onset Corporation HOBO Event data recorder and 8.2-inch-diameter tipping bucket. The bucket tips one time per 0.01 inch of rain, and the recorder stores data at 5 -minute intervals. The rain gage is calibrated approximately every 2 years and was last calibrated in March 2003.

Record.--The rain gage gave a complete and satisfactory record for the entire water year.

Period of Record.--October 1985 to present.

Remarks.--Record is good for the entire water year.

\begin{tabular}{|c|c|c|c|c|c|c|c|c|c|c|c|c|}
\hline \multirow[b]{2}{*}{ DAY } & \multirow[b]{2}{*}{ ОСт } & \multicolumn{2}{|c|}{ PRECIPITATION } & TOTAL, & \multicolumn{3}{|c|}{$\begin{array}{l}\text { INCHES WATER YEAR OCT } \\
\text { DAILY SUM VALUES }\end{array}$} & 2003 TO & \multicolumn{2}{|c|}{ SEPTEMBER 2004} & \multirow[b]{2}{*}{ AUG } & \multirow[b]{2}{*}{ SEF } \\
\hline & & NOV & $\mathrm{DEC}$ & JAN & FEB & MAR & APR & MAY & JUN & JUL & & \\
\hline 1 & 0.00 & 0.00 & 0.00 & 0.00 & 0.02 & 0.00 & 0.00 & 0.00 & 0.00 & 0.00 & 0.00 & 0.00 \\
\hline 2 & 0.00 & 0.00 & 0.00 & 0.00 & 0.00 & 0.16 & 0.22 & 0.00 & 0.00 & 0.00 & 0.08 & 0.00 \\
\hline 3 & 0.12 & 0.00 & 0.00 & 0.00 & 0.00 & 0.01 & 0.86 & 0.00 & 0.00 & 0.00 & 0.00 & 0.00 \\
\hline 4 & 0.05 & 0.00 & 0.00 & 0.00 & 0.04 & 0.78 & 0.13 & 0.00 & 0.00 & 0.00 & 0.19 & 0.03 \\
\hline 5 & 0.00 & 0.00 & 0.00 & 0.00 & 0.00 & 0.05 & 0.00 & 0.00 & 0.00 & 0.00 & 0.00 & 0.00 \\
\hline 6 & 0.00 & 0.00 & 0.00 & 0.00 & 0.00 & 0.00 & 0.00 & 0.00 & 0.00 & 0.00 & 0.00 & 0.00 \\
\hline 7 & 0.09 & 0.00 & 0.00 & 0.00 & 0.00 & 0.00 & 0.00 & 0.00 & 0.00 & 0.00 & 0.00 & 0.00 \\
\hline 8 & 0.97 & 0.00 & 0.02 & 0.00 & 0.00 & 0.00 & 0.22 & 0.00 & 0.00 & 0.00 & 0.00 & 0.00 \\
\hline 9 & 0.00 & 0.00 & 0.00 & 0.00 & 0.00 & 0.00 & 0.10 & 0.00 & 0.00 & 0.00 & 0.00 & 0.00 \\
\hline 10 & 0.00 & 0.00 & 0.00 & 0.00 & 0.00 & 0.00 & 0.24 & 0.00 & 0.00 & 0.00 & 0.02 & 0.00 \\
\hline 11 & 0.06 & 0.00 & 0.00 & 0.00 & 0.00 & 0.00 & 0.02 & 0.00 & 0.00 & 0.12 & 0.00 & 0.00 \\
\hline 12 & 0.01 & 0.71 & 0.15 & 0.00 & 0.00 & 0.00 & 0.00 & 0.00 & 0.00 & 1.19 & 0.00 & 0.00 \\
\hline 13 & 0.00 & 0.36 & 0.00 & 0.00 & 0.00 & 0.00 & 0.00 & 0.00 & 0.00 & 0.00 & 0.00 & 0.00 \\
\hline 14 & 0.00 & 0.00 & 0.00 & 0.00 & 0.00 & 0.00 & 0.00 & 0.00 & 0.00 & 0.00 & 0.00 & 0.00 \\
\hline 15 & 0.00 & 0.00 & 0.00 & 0.03 & 0.00 & 0.00 & 0.00 & 0.00 & 0.00 & 0.00 & 0.00 & 0.00 \\
\hline 16 & 0.00 & 0.00 & 0.00 & 0.01 & 0.00 & 0.00 & 0.00 & 0.00 & 0.00 & 0.00 & 0.00 & 0.00 \\
\hline 17 & 0.00 & 0.02 & 0.00 & 0.00 & 0.00 & 0.00 & 0.00 & 0.00 & 0.00 & 0.00 & 0.00 & 0.00 \\
\hline 18 & 0.00 & 0.00 & 0.00 & 0.00 & 0.00 & 0.00 & 0.00 & 0.00 & 0.00 & 0.00 & 0.00 & 0.03 \\
\hline 19 & 0.00 & 0.00 & 0.00 & 0.00 & 0.00 & 0.00 & 0.00 & 0.00 & 0.00 & 0.00 & 0.02 & 1.00 \\
\hline 20 & 0.00 & 0.00 & 0.00 & 0.14 & 0.00 & 0.00 & 0.00 & 0.00 & 0.00 & 0.13 & 0.00 & 0.04 \\
\hline 21 & 0.00 & 0.00 & 0.00 & 0.01 & 0.08 & 0.00 & 0.00 & 0.00 & 0.00 & 0.01 & 0.00 & 0.00 \\
\hline 22 & 0.00 & 0.00 & 0.00 & 0.00 & 0.01 & 0.00 & 0.00 & 0.00 & 0.00 & 0.10 & 0.00 & 0.00 \\
\hline 23 & 0.00 & 0.00 & 0.00 & 0.00 & 0.71 & 0.03 & 0.00 & 0.00 & 0.00 & 0.98 & 0.00 & 0.00 \\
\hline 24 & 0.00 & 0.00 & 0.00 & 0.00 & 0.23 & 0.00 & 0.00 & 0.00 & 0.00 & 0.17 & 0.00 & 0.00 \\
\hline 25 & 0.00 & 0.00 & 0.00 & 0.07 & 0.00 & 0.00 & 0.00 & 0.00 & 0.00 & 0.28 & 0.00 & 0.00 \\
\hline 26 & 0.00 & 0.00 & 0.00 & 0.01 & 0.00 & 0.00 & 0.00 & 0.00 & 0.12 & 0.00 & 0.00 & 0.00 \\
\hline 27 & 0.00 & 0.00 & 0.00 & 0.00 & 0.00 & 0.00 & 0.00 & 0.00 & 0.00 & 0.45 & 0.00 & 0.00 \\
\hline 28 & 0.00 & 0.00 & 0.00 & 0.00 & 0.14 & 0.00 & 0.00 & 0.00 & 0.00 & 0.00 & 0.00 & 0.00 \\
\hline 29 & 0.00 & 0.00 & 0.00 & 0.00 & 0.00 & 0.00 & 0.00 & 0.00 & 0.47 & 0.00 & 0.00 & 0.24 \\
\hline 30 & 0.00 & 0.00 & 0.00 & 0.00 & --- & 0.00 & 0.00 & 0.00 & 0.00 & 0.00 & 0.00 & 0.00 \\
\hline 31 & 0.00 & --- & 0.00 & 0.00 & --- & 0.00 & --- & 0.00 & --- & 0.00 & 0.00 & --- \\
\hline TOTAL & 1.30 & 1.09 & 0.17 & 0.27 & 1.23 & 1.03 & 1.79 & 0.00 & 0.59 & 3.43 & 0.31 & 1.34 \\
\hline MAX & 0.97 & 0.71 & 0.15 & 0.14 & 0.71 & 0.78 & 0.86 & 0.00 & 0.47 & 1.19 & 0.19 & 1.00 \\
\hline MIN & 0.00 & 0.00 & 0.00 & 0.00 & 0.00 & 0.00 & 0.00 & 0.00 & 0.00 & 0.00 & 0.00 & 0.00 \\
\hline
\end{tabular}

CAL YR 2003 TOTAL 8.19 MAX 1.24 MIN 0.00

WTR YR 2004 TOTAL 12.55 MAX 1.19 MIN 0.00 
Location.-- $35^{\circ} 05^{\prime} 15^{\prime \prime} \mathrm{N}, 106^{\circ} 39^{\prime} 05^{\prime \prime} \mathrm{W}$. The rain gage is located in northwest Albuquerque on the roof of Albuquerque City Hall, just west of City Plaza.

Equipment.--Onset Corporation HOBO Event data recorder and 8.0-inch-diameter tipping bucket. The bucket tips one time per 0.01 inch of rain, and the recorder stores data at 5 -minute intervals. Rain gage is calibrated approximately every 2 years and was last calibrated in March 2003.

Record.--The rain gage gave a complete and satisfactory record for the entire water year except for August 12 to September 1. During this period the rain gage was moved by unknown building maintenance personnel. Estimated daily totals for these days are the averages of daily totals from the Bernalillo County Building and Campus Wash rain gages.

Period of Record.--October 1994 to present.

Remarks.--Record is good for the entire water year, including days estimated as zero; other estimates are poor.

PRECIPITATION, TOTAL, INCHES, WATER YEAR OCTOBER 2003 TO SEPTEMBER 2004 DAILY SUM VALUES

\begin{tabular}{|c|c|c|c|c|c|c|c|c|c|c|c|c|}
\hline DAY & ОСт & Nov & DEC & JAN & FEB & MAR & APR & MAY & JUN & JUL & AUG & SEP \\
\hline 1 & 0.00 & 0.00 & 0.00 & 0.00 & 0.00 & 0.00 & 0.00 & 0.00 & 0.00 & 0.00 & 0.00 & $\mathrm{e} 0.00$ \\
\hline 2 & 0.00 & 0.00 & 0.00 & 0.00 & 0.00 & 0.10 & 0.41 & 0.00 & 0.00 & 0.00 & 0.06 & 0.00 \\
\hline 3 & 0.09 & 0.00 & 0.00 & 0.00 & 0.01 & 0.00 & 1.67 & 0.00 & 0.00 & 0.00 & 0.00 & 0.00 \\
\hline 4 & 0.03 & 0.00 & 0.00 & 0.00 & 0.00 & 0.65 & 0.09 & 0.00 & 0.00 & 0.00 & 0.00 & 0.07 \\
\hline 5 & 0.00 & 0.00 & 0.00 & 0.00 & 0.00 & 0.02 & 0.00 & 0.00 & 0.00 & 0.00 & 0.00 & 0.00 \\
\hline 6 & 0.00 & 0.00 & 0.00 & 0.00 & 0.00 & 0.00 & 0.00 & 0.00 & 0.00 & 0.00 & 0.00 & 0.00 \\
\hline 7 & 0.77 & 0.00 & 0.00 & 0.00 & 0.00 & 0.00 & 0.00 & 0.00 & 0.00 & 0.00 & 0.00 & 0.00 \\
\hline 8 & 0.21 & 0.00 & 0.01 & 0.00 & 0.00 & 0.00 & 0.26 & 0.00 & 0.00 & 0.00 & 0.00 & 0.00 \\
\hline 9 & 0.00 & 0.00 & 0.00 & 0.00 & 0.00 & 0.00 & 0.01 & 0.00 & 0.00 & 0.00 & 0.00 & 0.00 \\
\hline 10 & 0.16 & 0.00 & 0.00 & 0.00 & 0.00 & 0.00 & 0.31 & 0.00 & 0.00 & 0.00 & 0.02 & 0.00 \\
\hline 11 & 0.00 & 0.00 & 0.00 & 0.00 & 0.00 & 0.00 & 0.00 & 0.00 & 0.00 & 0.00 & 0.01 & 0.00 \\
\hline 12 & 0.00 & 0.48 & 0.11 & 0.00 & 0.00 & 0.00 & 0.00 & 0.00 & 0.00 & 0.21 & e0.00 & 0.00 \\
\hline 13 & 0.00 & 0.19 & 0.01 & 0.00 & 0.00 & 0.00 & 0.00 & 0.00 & 0.00 & 0.00 & e0.00 & 0.00 \\
\hline 14 & 0.00 & 0.00 & 0.00 & 0.00 & 0.00 & 0.00 & 0.00 & 0.00 & 0.00 & 0.00 & $\mathrm{e} 0.00$ & 0.00 \\
\hline 15 & 0.00 & 0.00 & 0.00 & 0.03 & 0.00 & 0.00 & 0.00 & 0.00 & 0.00 & 0.36 & e0.09 & 0.00 \\
\hline 16 & 0.00 & 0.00 & 0.00 & 0.01 & 0.00 & 0.00 & 0.00 & 0.00 & 0.00 & 0.00 & e0.00 & 0.00 \\
\hline 17 & 0.00 & 0.00 & 0.00 & 0.00 & 0.00 & 0.00 & 0.00 & 0.00 & 0.00 & 0.00 & e0.00 & 0.00 \\
\hline 18 & 0.00 & 0.00 & 0.00 & 0.00 & 0.00 & 0.00 & 0.00 & 0.00 & 0.00 & 0.01 & e0.02 & 0.11 \\
\hline 19 & 0.00 & 0.00 & 0.00 & 0.00 & 0.00 & 0.00 & 0.00 & 0.00 & 0.00 & 0.18 & e0.02 & 0.52 \\
\hline 20 & 0.00 & 0.00 & 0.00 & 0.06 & 0.00 & 0.00 & 0.00 & 0.00 & 0.00 & 0.07 & e0.00 & 0.03 \\
\hline 21 & 0.00 & 0.00 & 0.00 & 0.00 & 0.02 & 0.00 & 0.00 & 0.00 & 0.00 & 0.01 & e0.00 & 0.00 \\
\hline 22 & 0.00 & 0.00 & 0.00 & 0.00 & 0.00 & 0.00 & 0.00 & 0.00 & 0.00 & 0.18 & e0.00 & 0.00 \\
\hline 23 & 0.00 & 0.00 & 0.00 & 0.00 & 0.78 & 0.02 & 0.00 & 0.00 & 0.00 & 1.06 & e0.00 & 0.00 \\
\hline 24 & 0.00 & 0.00 & 0.00 & 0.00 & 0.33 & 0.00 & 0.00 & 0.00 & 0.00 & 0.23 & e0.00 & 0.00 \\
\hline 25 & 0.00 & 0.00 & 0.00 & 0.03 & 0.00 & 0.00 & 0.00 & 0.00 & 0.00 & 0.32 & e0.00 & 0.00 \\
\hline 26 & 0.00 & 0.00 & 0.00 & 0.00 & 0.00 & 0.00 & 0.00 & 0.00 & 0.00 & 0.00 & e0.00 & 0.00 \\
\hline 27 & 0.00 & 0.00 & 0.00 & 0.00 & 0.00 & 0.00 & 0.00 & 0.00 & 0.00 & 0.12 & e0.00 & 0.00 \\
\hline 28 & 0.00 & 0.00 & 0.00 & 0.00 & 0.14 & 0.00 & 0.00 & 0.00 & 0.00 & 0.00 & $\mathrm{e} 0.00$ & 0.00 \\
\hline 29 & 0.00 & 0.00 & 0.00 & 0.00 & 0.00 & 0.00 & 0.00 & 0.00 & 0.71 & 0.00 & $e 0.03$ & 0.02 \\
\hline 30 & 0.00 & 0.00 & 0.00 & 0.00 & --- & 0.00 & 0.00 & 0.00 & 0.00 & 0.00 & e0.03 & 0.01 \\
\hline 31 & 0.00 & --- & 0.00 & 0.00 & --- & 0.00 & --- & 0.00 & --- & 0.00 & e0.00 & --- \\
\hline TOTAL & 1.26 & 0.67 & 0.13 & 0.13 & 1.28 & 0.79 & 2.75 & 0.00 & 0.71 & 2.75 & 0.28 & 0.76 \\
\hline MAX & 0.77 & 0.48 & 0.11 & 0.06 & 0.78 & 0.65 & 1.67 & 0.00 & 0.71 & 1.06 & 0.09 & 0.52 \\
\hline MIN & 0.00 & 0.00 & 0.00 & 0.00 & 0.00 & 0.00 & 0.00 & 0.00 & 0.00 & 0.00 & 0.00 & 0.00 \\
\hline
\end{tabular}


Location.--35 $06^{\prime} 27^{\prime \prime} \mathrm{N}, 106^{\circ} 36^{\prime} 47^{\prime \prime} \mathrm{W}$. The AMAFCA headquarters are located in northeast Albuquerque, west of Carlisle Boulevard on Manual Boulevard behind the Summer Suites Hotel. The rain gage is in the maintenance yard.

Equipment.--Onset Corporation HOBO Event data recorder and 6.3-inch-diameter tipping bucket. The bucket tips one time per 0.01 inch of rain, and the recorder stores data at 5-minute intervals. Rain gage is calibrated approximately every 2 years and was last calibrated in March 2003.

Record.--The rain gage gave a complete and satisfactory record for the water year.

Period of Record.--September 1997 to present.

Remarks.--Record is good for the entire water year.

PRECIPITATION, TOTAL, WATER YEAR OCTOBER 2003 TO SEPTEMBER 2004

DAILY SUM VALUES

\begin{tabular}{|c|c|c|c|c|c|c|c|c|c|c|c|c|}
\hline DAY & ОСт & NOV & DEC & JAN & FEB & MAR & APR & MAY & JUN & JUL & AUG & SEP \\
\hline 1 & 0.00 & 0.00 & 0.00 & 0.00 & 0.02 & 0.00 & 0.00 & 0.00 & 0.00 & 0.00 & 0.00 & 0.00 \\
\hline 2 & 0.00 & 0.00 & 0.00 & 0.00 & 0.00 & 0.10 & 0.37 & 0.00 & 0.00 & 0.00 & 0.09 & 0.00 \\
\hline 3 & 0.11 & 0.00 & 0.00 & 0.00 & 0.02 & 0.01 & 1.44 & 0.00 & 0.00 & 0.00 & 0.00 & 0.00 \\
\hline 4 & 0.02 & 0.00 & 0.00 & 0.00 & 0.00 & 0.71 & 0.07 & 0.00 & 0.00 & 0.00 & 0.06 & 0.05 \\
\hline 5 & 0.00 & 0.00 & 0.00 & 0.00 & 0.00 & 0.03 & 0.00 & 0.00 & 0.00 & 0.00 & 0.00 & 0.00 \\
\hline 6 & 0.00 & 0.00 & 0.00 & 0.00 & 0.00 & 0.00 & 0.00 & 0.00 & 0.00 & 0.00 & 0.00 & 0.00 \\
\hline 7 & 1.02 & 0.00 & 0.00 & 0.00 & 0.00 & 0.00 & 0.00 & 0.00 & 0.00 & 0.00 & 0.00 & 0.00 \\
\hline 8 & 0.21 & 0.00 & 0.01 & 0.00 & 0.00 & 0.00 & 0.25 & 0.00 & 0.00 & 0.00 & 0.00 & 0.00 \\
\hline 9 & 0.00 & 0.00 & 0.00 & 0.00 & 0.00 & 0.00 & 0.01 & 0.00 & 0.00 & 0.00 & 0.00 & 0.00 \\
\hline 10 & 0.11 & 0.00 & 0.00 & 0.00 & 0.00 & 0.00 & 0.23 & 0.00 & 0.00 & 0.00 & 0.10 & 0.00 \\
\hline 11 & 0.01 & 0.00 & 0.00 & 0.00 & 0.00 & 0.00 & 0.00 & 0.00 & 0.00 & 0.03 & 0.03 & 0.00 \\
\hline 12 & 0.00 & 0.55 & 0.13 & 0.00 & 0.00 & 0.01 & 0.00 & 0.00 & 0.00 & 0.82 & 0.00 & 0.00 \\
\hline 13 & 0.00 & 0.20 & 0.00 & 0.00 & 0.00 & 0.00 & 0.00 & 0.00 & 0.00 & 0.00 & 0.00 & 0.00 \\
\hline 14 & 0.00 & 0.00 & 0.00 & 0.00 & 0.00 & 0.00 & 0.00 & 0.00 & 0.00 & 0.01 & 0.00 & 0.00 \\
\hline 15 & 0.00 & 0.00 & 0.00 & 0.04 & 0.00 & 0.00 & 0.00 & 0.00 & 0.00 & 0.45 & 0.00 & 0.00 \\
\hline 16 & 0.00 & 0.00 & 0.00 & 0.01 & 0.00 & 0.00 & 0.00 & 0.00 & 0.00 & 0.00 & 0.00 & 0.00 \\
\hline 17 & 0.00 & 0.00 & 0.00 & 0.00 & 0.00 & 0.00 & 0.03 & 0.00 & 0.00 & 0.00 & 0.00 & 0.00 \\
\hline 18 & 0.00 & 0.00 & 0.00 & 0.00 & 0.00 & 0.00 & 0.00 & 0.00 & 0.00 & 0.04 & 0.00 & 0.09 \\
\hline 19 & 0.00 & 0.00 & 0.00 & 0.00 & 0.00 & 0.00 & 0.00 & 0.00 & 0.00 & 0.00 & 0.14 & 0.83 \\
\hline 20 & 0.00 & 0.00 & 0.00 & 0.07 & 0.00 & 0.00 & 0.00 & 0.00 & 0.00 & 0.05 & 0.00 & 0.03 \\
\hline 21 & 0.00 & 0.00 & 0.00 & 0.00 & 0.05 & 0.00 & 0.00 & 0.00 & 0.00 & 0.00 & 0.00 & 0.00 \\
\hline 22 & 0.00 & 0.00 & 0.00 & 0.00 & 0.00 & 0.00 & 0.00 & 0.00 & 0.00 & 0.00 & 0.00 & 0.00 \\
\hline 23 & 0.00 & 0.00 & 0.00 & 0.00 & 0.88 & 0.08 & 0.00 & 0.00 & 0.00 & 1.03 & 0.00 & 0.00 \\
\hline 24 & 0.00 & 0.00 & 0.00 & 0.00 & 0.26 & 0.00 & 0.00 & 0.00 & 0.00 & 0.10 & 0.00 & 0.00 \\
\hline 25 & 0.00 & 0.00 & 0.00 & 0.10 & 0.02 & 0.00 & 0.00 & 0.00 & 0.00 & 0.36 & 0.00 & 0.00 \\
\hline 26 & 0.00 & 0.00 & 0.00 & 0.01 & 0.00 & 0.00 & 0.00 & 0.00 & 0.09 & 0.00 & 0.00 & 0.00 \\
\hline 27 & 0.00 & 0.00 & 0.00 & 0.00 & 0.00 & 0.00 & 0.00 & 0.00 & 0.00 & 0.26 & 0.00 & 0.00 \\
\hline 28 & 0.00 & 0.00 & 0.00 & 0.00 & 0.16 & 0.00 & 0.00 & 0.00 & 0.01 & 0.05 & 0.00 & 0.00 \\
\hline 29 & 0.00 & 0.00 & 0.00 & 0.00 & 0.00 & 0.00 & 0.00 & 0.00 & 0.63 & 0.00 & 0.00 & 0.08 \\
\hline 30 & 0.00 & 0.00 & 0.00 & 0.00 & --- & 0.00 & 0.00 & 0.00 & 0.00 & 0.00 & 0.01 & 0.00 \\
\hline 31 & 0.00 & --- & 0.00 & 0.00 & --- & 0.00 & --- & 0.00 & --- & 0.00 & 0.00 & --- \\
\hline TOTAL & 1.48 & 0.75 & 0.14 & 0.23 & 1.41 & 0.94 & 2.40 & 0.00 & 0.73 & 3.20 & 0.43 & 1.08 \\
\hline MAX & 1.02 & 0.55 & 0.13 & 0.10 & 0.88 & 0.71 & 1.44 & 0.00 & 0.63 & 1.03 & 0.14 & 0.83 \\
\hline MIN & 0.00 & 0.00 & 0.00 & 0.00 & 0.00 & 0.00 & 0.00 & 0.00 & 0.00 & 0.00 & 0.00 & 0.00 \\
\hline
\end{tabular}

CAL YR 2003 TOTAL 6.30 MAX 1.02 MIN 0.00

WTR YR 2004 TOTAL 12.79 MAX 1.44 MIN 0.00 


\section{5, ARROYO 19A RAIN GAGE AT ALBUQUERQUE, NEW MEXICO STATION ANALYSIS \\ WATER YEAR 2004}

Location.--3509'24”N, 106 43'50’W. The rain gage is located west of Albuquerque on Volcano Hill, west of Unser Boulevard and west of Petroglyphs National Park.

Equipment.--Onset Corporation HOBO Event data recorder and 8.2-inch-diameter tipping bucket. The bucket tips one time per 0.01 inch of rain, and the recorder stores data at 5-minute intervals. Rain gage is calibrated approximately every 2 years and was last calibrated in March 2003.

Record.--The rain gage gave a complete and satisfactory record for the entire water year.

Period of Record.--October 1986 to present.

Remarks.--Record is good for the entire water year.

PRECIPITATION, TOTAL, WATER YEAR OCTOBER 2003 TO SEPTEMBER 2004 DAILY SUM VALUES

\begin{tabular}{|c|c|c|c|c|c|c|c|c|c|c|c|c|}
\hline DAY & ОСт & NOV & $\mathrm{DEC}$ & JAN & FEB & MAR & APR & MAY & JUN & JUL & AUG & SEP \\
\hline 1 & 0.00 & 0.02 & 0.00 & 0.00 & 0.00 & 0.00 & 0.00 & 0.00 & 0.00 & 0.00 & 0.00 & 0.00 \\
\hline 2 & 0.00 & 0.00 & 0.00 & 0.00 & 0.00 & 0.21 & 0.58 & 0.00 & 0.00 & 0.00 & 0.06 & 0.00 \\
\hline 3 & 0.09 & 0.00 & 0.00 & 0.00 & 0.01 & 0.01 & 1.45 & 0.00 & 0.00 & 0.00 & 0.00 & 0.21 \\
\hline 4 & 0.03 & 0.00 & 0.00 & 0.00 & 0.00 & 0.68 & 0.16 & 0.00 & 0.00 & 0.00 & 0.01 & 0.06 \\
\hline 5 & 0.00 & 0.00 & 0.00 & 0.00 & 0.00 & 0.02 & 0.00 & 0.00 & 0.00 & 0.00 & 0.09 & 0.01 \\
\hline 6 & 0.00 & 0.00 & 0.00 & 0.00 & 0.00 & 0.00 & 0.00 & 0.00 & 0.00 & 0.00 & 0.00 & 0.00 \\
\hline 7 & 0.79 & 0.00 & 0.00 & 0.00 & 0.00 & 0.00 & 0.00 & 0.00 & 0.00 & 0.00 & 0.00 & 0.00 \\
\hline 8 & 0.25 & 0.00 & 0.04 & 0.00 & 0.00 & 0.00 & 0.23 & 0.00 & 0.00 & 0.00 & 0.00 & 0.00 \\
\hline 9 & 0.00 & 0.00 & 0.00 & 0.00 & 0.00 & 0.00 & 0.02 & 0.00 & 0.00 & 0.00 & 0.00 & 0.00 \\
\hline 10 & 0.00 & 0.00 & 0.00 & 0.00 & 0.00 & 0.00 & 0.35 & 0.00 & 0.00 & 0.00 & 0.00 & 0.00 \\
\hline 11 & 0.00 & 0.00 & 0.00 & 0.00 & 0.00 & 0.00 & 0.00 & 0.00 & 0.00 & 0.00 & 0.02 & 0.00 \\
\hline 12 & 0.00 & 0.58 & 0.10 & 0.00 & 0.00 & 0.00 & 0.00 & 0.00 & 0.00 & 0.05 & 0.00 & 0.00 \\
\hline 13 & 0.00 & 0.15 & 0.00 & 0.00 & 0.00 & 0.00 & 0.00 & 0.00 & 0.00 & 0.00 & 0.04 & 0.00 \\
\hline 14 & 0.00 & 0.00 & 0.00 & 0.00 & 0.00 & 0.00 & 0.00 & 0.00 & 0.00 & 0.00 & 0.00 & 0.00 \\
\hline 15 & 0.00 & 0.00 & 0.00 & 0.05 & 0.00 & 0.00 & 0.00 & 0.00 & 0.00 & 0.00 & 0.01 & 0.00 \\
\hline 16 & 0.00 & 0.00 & 0.00 & 0.01 & 0.00 & 0.00 & 0.00 & 0.00 & 0.00 & 0.00 & 0.00 & 0.00 \\
\hline 17 & 0.00 & 0.00 & 0.00 & 0.00 & 0.00 & 0.00 & 0.00 & 0.00 & 0.00 & 0.00 & 0.00 & 0.00 \\
\hline 18 & 0.00 & 0.00 & 0.00 & 0.00 & 0.00 & 0.00 & 0.00 & 0.00 & 0.00 & 0.00 & 0.00 & 0.11 \\
\hline 19 & 0.00 & 0.00 & 0.00 & 0.00 & 0.00 & 0.00 & 0.00 & 0.00 & 0.00 & 0.09 & 0.00 & 0.43 \\
\hline 20 & 0.00 & 0.00 & 0.00 & 0.07 & 0.00 & 0.00 & 0.00 & 0.00 & 0.00 & 0.04 & 0.00 & 0.00 \\
\hline 21 & 0.00 & 0.00 & 0.00 & 0.00 & 0.05 & 0.00 & 0.00 & 0.00 & 0.00 & 0.00 & 0.00 & 0.00 \\
\hline 22 & 0.00 & 0.00 & 0.00 & 0.00 & 0.00 & 0.00 & 0.00 & 0.00 & 0.00 & 0.66 & 0.00 & 0.00 \\
\hline 23 & 0.00 & 0.00 & 0.00 & 0.00 & 0.63 & 0.00 & 0.02 & 0.00 & 0.00 & 0.02 & 0.00 & 0.00 \\
\hline 24 & 0.00 & 0.00 & 0.00 & 0.00 & 0.40 & 0.00 & 0.00 & 0.00 & 0.00 & 0.53 & 0.00 & 0.00 \\
\hline 25 & 0.00 & 0.00 & 0.00 & 0.03 & 0.00 & 0.00 & 0.00 & 0.00 & 0.00 & 0.22 & 0.00 & 0.00 \\
\hline 26 & 0.00 & 0.00 & 0.00 & 0.00 & 0.00 & 0.00 & 0.00 & 0.00 & 0.01 & 0.00 & 0.00 & 0.00 \\
\hline 27 & 0.00 & 0.00 & 0.00 & 0.00 & 0.00 & 0.00 & 0.00 & 0.00 & 0.00 & 0.05 & 0.00 & 0.00 \\
\hline 28 & 0.00 & 0.00 & 0.00 & 0.00 & 0.13 & 0.00 & 0.00 & 0.00 & 0.00 & 0.00 & 0.00 & 0.00 \\
\hline 29 & 0.00 & 0.00 & 0.00 & 0.00 & 0.00 & 0.00 & 0.00 & 0.00 & 0.57 & 0.00 & 0.00 & 0.57 \\
\hline 30 & 0.00 & 0.00 & 0.00 & 0.00 & --- & 0.00 & 0.00 & 0.00 & 0.00 & 0.00 & 0.00 & 0.00 \\
\hline 31 & 0.00 & --- & 0.00 & 0.00 & --- & 0.00 & --- & 0.00 & --- & 0.00 & 0.00 & --- \\
\hline TOTAL & 1.16 & 0.75 & 0.14 & 0.16 & 1.22 & 0.92 & 2.81 & 0.00 & 0.58 & 1.66 & 0.23 & 1.39 \\
\hline MAX & 0.79 & 0.58 & 0.10 & 0.07 & 0.63 & 0.68 & 1.45 & 0.00 & 0.57 & 0.66 & 0.09 & 0.57 \\
\hline MIN & 0.00 & 0.00 & 0.00 & 0.00 & 0.00 & 0.00 & 0.00 & 0.00 & 0.00 & 0.00 & 0.00 & 0.00 \\
\hline
\end{tabular}




\section{0, BEAR CANYON RAIN GAGE IN ALBUQUERQUE, NEW MEXICO \\ STATION ANALYSIS \\ WATER YEAR 2004}

Location.--35'08'00'N , 106 $27^{\prime} 45^{\prime \prime} \mathrm{W}$. The rain gage is located on Albuquerque Academy property in the Sandia Mountains foothills, east of the intersection of Tramway Boulevard and Academy Road.

Equipment.--Onset Corporation HOBO Event data recorder and 7.9-inch-diameter tipping bucket. The bucket tips one time per 0.01 inch of rain, and the recorder stores data at 5-minute intervals. Rain gage is calibrated approximately every 2 years and was last calibrated in March 2003.

Record.--The rain gage gave a complete and satisfactory record for the entire water year

Period of Record.--October 1994 to present.

Remarks.--Record is good for the entire water year.

PRECIPITATION, TOTAL, WATER YEAR OCTOBER 2003 TO SEPTEMBER 2004 DAILY SUM VALUES

\begin{tabular}{|c|c|c|c|c|c|c|c|c|c|c|c|c|}
\hline DAY & ОСт & NOV & $\mathrm{DEC}$ & JAN & FEB & MAR & APR & MAY & JUN & JUL & AUG & SEP \\
\hline 1 & 0.02 & 0.00 & 0.00 & 0.00 & 0.09 & 0.00 & 0.00 & 0.00 & 0.00 & 0.00 & 0.00 & 0.00 \\
\hline 2 & 0.00 & 0.00 & 0.00 & 0.00 & 0.01 & 0.09 & 0.71 & 0.00 & 0.00 & 0.00 & 0.16 & 0.00 \\
\hline 3 & 0.09 & 0.00 & 0.00 & 0.00 & 0.00 & 0.00 & 2.39 & 0.00 & 0.00 & 0.00 & 0.00 & 0.00 \\
\hline 4 & 0.03 & 0.00 & 0.00 & 0.00 & 0.02 & 0.67 & 0.81 & 0.00 & 0.00 & 0.00 & 2.08 & 0.17 \\
\hline 5 & 0.00 & 0.00 & 0.00 & 0.00 & 0.00 & 0.29 & 0.00 & 0.00 & 0.00 & 0.00 & 0.00 & 0.00 \\
\hline 6 & 0.00 & 0.00 & 0.00 & 0.00 & 0.00 & 0.02 & 0.00 & 0.00 & 0.00 & 0.00 & 0.45 & 0.00 \\
\hline 7 & 0.58 & 0.00 & 0.00 & 0.00 & 0.00 & 0.00 & 0.00 & 0.00 & 0.00 & 0.00 & 0.00 & 0.00 \\
\hline 8 & 0.21 & 0.00 & 0.00 & 0.00 & 0.00 & 0.00 & 0.42 & 0.00 & 0.00 & 0.00 & 0.00 & 0.00 \\
\hline 9 & 0.00 & 0.00 & 0.03 & 0.00 & 0.00 & 0.00 & 0.15 & 0.00 & 0.00 & 0.00 & 0.00 & 0.00 \\
\hline 10 & 0.17 & 0.01 & 0.00 & 0.00 & 0.00 & 0.00 & 0.01 & 0.00 & 0.00 & 0.00 & 0.01 & 0.00 \\
\hline 11 & 0.00 & 0.00 & 0.00 & 0.00 & 0.00 & 0.00 & 0.13 & 0.00 & 0.00 & 0.11 & 0.00 & 0.00 \\
\hline 12 & 0.00 & 0.83 & 0.00 & 0.00 & 0.00 & 0.00 & 0.00 & 0.00 & 0.00 & 0.00 & 0.00 & 0.00 \\
\hline 13 & 0.00 & 0.31 & 0.19 & 0.00 & 0.00 & 0.00 & 0.00 & 0.00 & 0.00 & 0.00 & 0.03 & 0.00 \\
\hline 14 & 0.00 & 0.00 & 0.03 & 0.00 & 0.00 & 0.00 & 0.00 & 0.00 & 0.00 & 0.07 & 0.23 & 0.00 \\
\hline 15 & 0.00 & 0.00 & 0.00 & 0.14 & 0.00 & 0.00 & 0.00 & 0.00 & 0.00 & 0.00 & 0.00 & 0.00 \\
\hline 16 & 0.00 & 0.02 & 0.00 & 0.00 & 0.00 & 0.00 & 0.00 & 0.00 & 0.00 & 0.00 & 0.00 & 0.00 \\
\hline 17 & 0.00 & 0.00 & 0.00 & 0.00 & 0.00 & 0.00 & 0.00 & 0.00 & 0.00 & 0.00 & 0.00 & 0.00 \\
\hline 18 & 0.00 & 0.00 & 0.00 & 0.00 & 0.00 & 0.00 & 0.00 & 0.00 & 0.00 & 0.03 & 0.00 & 0.06 \\
\hline 19 & 0.00 & 0.00 & 0.00 & 0.00 & 0.00 & 0.00 & 0.00 & 0.00 & 0.00 & 0.25 & 0.04 & 1.05 \\
\hline 20 & 0.00 & 0.00 & 0.00 & 0.11 & 0.00 & 0.00 & 0.00 & 0.00 & 0.00 & 0.15 & 0.00 & 0.12 \\
\hline 21 & 0.00 & 0.00 & 0.00 & 0.00 & 0.19 & 0.00 & 0.00 & 0.00 & 0.00 & 0.00 & 0.02 & 0.00 \\
\hline 22 & 0.00 & 0.00 & 0.01 & 0.00 & 0.00 & 0.00 & 0.00 & 0.00 & 0.00 & 0.56 & 0.00 & 0.00 \\
\hline 23 & 0.00 & 0.00 & 0.00 & 0.00 & 0.31 & 0.06 & 0.01 & 0.00 & 0.00 & 0.26 & 0.00 & 0.00 \\
\hline 24 & 0.00 & 0.00 & 0.00 & 0.00 & 0.17 & 0.01 & 0.00 & 0.00 & 0.00 & 0.91 & 0.00 & 0.00 \\
\hline 25 & 0.00 & 0.00 & 0.00 & 0.00 & 0.98 & 0.00 & 0.00 & 0.00 & 0.01 & 0.28 & 0.00 & 0.00 \\
\hline 26 & 0.00 & 0.00 & 0.00 & 0.00 & 0.03 & 0.00 & 0.00 & 0.00 & 0.18 & 0.00 & 0.00 & 0.01 \\
\hline 27 & 0.00 & 0.00 & 0.00 & 0.02 & 0.00 & 0.00 & 0.00 & 0.00 & 0.00 & 0.22 & 0.00 & 0.00 \\
\hline 28 & 0.00 & 0.00 & 0.00 & 0.00 & 0.24 & 0.00 & 0.00 & 0.00 & 0.17 & 0.00 & 0.00 & 0.00 \\
\hline 29 & 0.00 & 0.00 & 0.00 & 0.00 & 0.00 & 0.00 & 0.00 & 0.00 & 1.37 & 0.00 & 0.01 & 0.00 \\
\hline 30 & 0.00 & 0.00 & 0.00 & 0.00 & --- & 0.00 & 0.00 & 0.00 & 0.00 & 0.00 & 0.00 & 0.00 \\
\hline 31 & 0.00 & --- & 0.00 & 0.00 & --- & 0.00 & --- & 0.00 & --- & 0.00 & 0.00 & --- \\
\hline TOTAL & 1.10 & 1.17 & 0.26 & 0.27 & 2.04 & 1.14 & 4.63 & 0.00 & 1.73 & 2.84 & 3.03 & 1.41 \\
\hline MAX & 0.58 & 0.83 & 0.19 & 0.14 & 0.98 & 0.67 & 2.39 & 0.00 & 1.37 & 0.91 & 2.08 & 1.05 \\
\hline MIN & 0.00 & 0.00 & 0.00 & 0.00 & 0.00 & 0.00 & 0.00 & 0.00 & 0.00 & 0.00 & 0.00 & 0.00 \\
\hline
\end{tabular}




\section{0, BERNALILLO COUNTY BUILDING RAIN GAGE NEAR ALBUQUERQUE, NEW MEXICO \\ STATION ANALYSIS \\ WATER YEAR 2004}

Location.--35'03'29'N, 106 38'40'W. The rain gage is located in southeast Albuquerque on the roof of a Bernalillo County office building, south of the intersection of Gibson and Broadway Boulevards.

Equipment.--Onset Corporation HOBO Event data recorder and 6.3-inch-diameter tipping bucket. The bucket tips one time per 0.01 inch of rain, and the recorder stores data at 5-minute intervals. Rain gage is calibrated approximately every 2 years and was last calibrated in March 2003.

Record.--The rain gage gave a complete and satisfactory record for the water year.

Period of Record.--October 1994 to present.

Remarks.-- Record is good for the entire water year.

PRECIPITATION, TOTAL, INCHES, WATER YEAR OCTOBER 2003 TO SEPTEMBER 2004 DAILY SUM VALUES

\begin{tabular}{|c|c|c|c|c|c|c|c|c|c|c|c|c|}
\hline DAY & ОСт & NOV & DEC & JAN & FEB & MAR & APR & MAY & JUN & JUL & AUG & SEP \\
\hline 1 & 0.00 & 0.00 & 0.00 & 0.00 & 0.00 & 0.00 & 0.00 & 0.00 & 0.00 & 0.00 & 0.00 & 0.00 \\
\hline 2 & 0.00 & 0.00 & 0.00 & 0.00 & 0.00 & 0.00 & 0.51 & 0.00 & 0.00 & 0.00 & 0.05 & 0.00 \\
\hline 3 & 0.12 & 0.00 & 0.00 & 0.00 & 0.00 & 0.00 & 1.87 & 0.00 & 0.00 & 0.00 & 0.00 & 0.00 \\
\hline 4 & 0.01 & 0.00 & 0.00 & 0.00 & 0.01 & 0.56 & 0.14 & 0.00 & 0.00 & 0.00 & 0.00 & 0.09 \\
\hline 5 & 0.00 & 0.00 & 0.00 & 0.00 & 0.00 & 0.03 & 0.00 & 0.00 & 0.00 & 0.00 & 0.00 & 0.00 \\
\hline 6 & 0.00 & 0.00 & 0.00 & 0.00 & 0.00 & 0.00 & 0.00 & 0.00 & 0.00 & 0.00 & 0.00 & 0.00 \\
\hline 7 & 1.24 & 0.00 & 0.00 & 0.00 & 0.00 & 0.00 & 0.02 & 0.00 & 0.00 & 0.00 & 0.00 & 0.00 \\
\hline 8 & 0.23 & 0.00 & 0.00 & 0.00 & 0.00 & 0.00 & 0.36 & 0.00 & 0.00 & 0.00 & 0.00 & 0.00 \\
\hline 9 & 0.00 & 0.00 & 0.00 & 0.00 & 0.00 & 0.00 & 0.00 & 0.00 & 0.00 & 0.00 & 0.00 & 0.00 \\
\hline 10 & 0.30 & 0.00 & 0.00 & 0.00 & 0.00 & 0.00 & 0.27 & 0.00 & 0.00 & 0.00 & 0.10 & 0.00 \\
\hline 11 & 0.00 & 0.00 & 0.00 & 0.00 & 0.00 & 0.00 & 0.00 & 0.00 & 0.00 & 0.00 & 0.03 & 0.00 \\
\hline 12 & 0.00 & 0.52 & 0.17 & 0.00 & 0.00 & 0.00 & 0.00 & 0.00 & 0.00 & 0.49 & 0.00 & 0.00 \\
\hline 13 & 0.00 & 0.20 & 0.00 & 0.00 & 0.00 & 0.00 & 0.00 & 0.00 & 0.00 & 0.00 & 0.00 & 0.00 \\
\hline 14 & 0.00 & 0.00 & 0.00 & 0.00 & 0.00 & 0.00 & 0.00 & 0.00 & 0.00 & 0.00 & 0.00 & 0.00 \\
\hline 15 & 0.00 & 0.01 & 0.00 & 0.05 & 0.00 & 0.00 & 0.00 & 0.00 & 0.00 & 0.77 & 0.18 & 0.00 \\
\hline 16 & 0.00 & 0.03 & 0.00 & 0.02 & 0.00 & 0.00 & 0.00 & 0.00 & 0.00 & 0.00 & 0.00 & 0.00 \\
\hline 17 & 0.00 & 0.01 & 0.00 & 0.00 & 0.00 & 0.00 & 0.02 & 0.00 & 0.00 & 0.00 & 0.00 & 0.00 \\
\hline 18 & 0.00 & 0.00 & 0.00 & 0.00 & 0.00 & 0.00 & 0.00 & 0.00 & 0.00 & 0.10 & 0.03 & 0.12 \\
\hline 19 & 0.00 & 0.00 & 0.00 & 0.00 & 0.00 & 0.00 & 0.00 & 0.00 & 0.00 & 0.00 & 0.01 & 0.75 \\
\hline 20 & 0.00 & 0.00 & 0.00 & 0.07 & 0.00 & 0.00 & 0.00 & 0.00 & 0.00 & 0.06 & 0.00 & 0.02 \\
\hline 21 & 0.00 & 0.00 & 0.00 & 0.00 & 0.08 & 0.00 & 0.00 & 0.00 & 0.00 & 0.01 & 0.00 & 0.00 \\
\hline 22 & 0.00 & 0.00 & 0.00 & 0.00 & 0.01 & 0.00 & 0.00 & 0.00 & 0.01 & 0.50 & 0.00 & 0.00 \\
\hline 23 & 0.00 & 0.00 & 0.00 & 0.00 & 0.80 & 0.05 & 0.00 & 0.00 & 0.00 & 1.34 & 0.00 & 0.00 \\
\hline 24 & 0.00 & 0.00 & 0.00 & 0.00 & 0.16 & 0.00 & 0.00 & 0.00 & 0.00 & 0.25 & 0.00 & 0.00 \\
\hline 25 & 0.00 & 0.00 & 0.00 & 0.00 & 0.00 & 0.00 & 0.00 & 0.00 & 0.00 & 0.36 & 0.00 & 0.00 \\
\hline 26 & 0.00 & 0.00 & 0.00 & 0.00 & 0.00 & 0.00 & 0.00 & 0.00 & 0.00 & 0.00 & 0.00 & 0.00 \\
\hline 27 & 0.00 & 0.00 & 0.00 & 0.00 & 0.00 & 0.00 & 0.00 & 0.00 & 0.00 & 0.07 & 0.00 & 0.00 \\
\hline 28 & 0.00 & 0.00 & 0.00 & 0.00 & 0.00 & 0.00 & 0.00 & 0.00 & 0.08 & 0.00 & 0.00 & 0.00 \\
\hline 29 & 0.00 & 0.00 & 0.00 & 0.00 & 0.00 & 0.00 & 0.00 & 0.00 & 0.56 & 0.00 & 0.00 & 0.08 \\
\hline 30 & 0.00 & 0.00 & 0.00 & 0.00 & --- & 0.00 & 0.00 & 0.00 & 0.00 & 0.00 & 0.04 & 0.01 \\
\hline 31 & 0.00 & --- & 0.00 & 0.00 & --- & 0.00 & --- & 0.00 & --- & 0.00 & 0.00 & --- \\
\hline TOTAL & 1.90 & 0.77 & 0.17 & 0.14 & 1.06 & 0.64 & 3.19 & 0.00 & 0.65 & 3.95 & 0.44 & 1.07 \\
\hline MAX & 1.24 & 0.52 & 0.17 & 0.07 & 0.80 & 0.56 & 1.87 & 0.00 & 0.56 & 1.34 & 0.18 & 0.75 \\
\hline MIN & 0.00 & 0.00 & 0.00 & 0.00 & 0.00 & 0.00 & 0.00 & 0.00 & 0.00 & 0.00 & 0.00 & 0.00 \\
\hline
\end{tabular}




\section{0, BORLAND RAIN GAGE IN ALBUQUERQUE, NEW MEXICO \\ STATION ANALYSIS \\ WATER YEAR 2004}

Location.-- $35^{\circ} 07^{\prime} 14^{\prime \prime} \mathrm{N}, 106^{\circ} 31^{\prime} 45^{\prime \prime} \mathrm{W}$. The rain gage is located on private property in northeast Albuquerque near the intersection of Candelaria Road and Eubank Boulevard.

Equipment.--Onset Corporation HOBO Event data recorder and 7.9-inch-diameter tipping bucket. The bucket tips one time per 0.01 inch of rain, and the recorder stores data at 5-minute intervals. Rain gage is calibrated approximately every 2 years and was last calibrated in March 2003.

Record.--The rain gage gave a complete and satisfactory record for the entire water year.

Period of Record.--October 1994 to present.

Remarks.--Record is good for the entire water year.

PRECIPITATION, TOTAL, INCHES, WATER YEAR OCTOBER 2003 TO SEPTEMBER 2004 DAILY SUM VALUES

\begin{tabular}{|c|c|c|c|c|c|c|c|c|c|c|c|c|}
\hline DAY & OCT & NOV & DEC & JAN & FEB & MAR & APR & MAY & JUN & JUL & AUG & SEP \\
\hline 1 & 0.00 & 0.00 & 0.00 & 0.00 & 0.09 & 0.00 & 0.00 & 0.00 & 0.00 & 0.00 & 0.00 & 0.00 \\
\hline 2 & 0.00 & 0.00 & 0.00 & 0.00 & 0.00 & 0.10 & 0.30 & 0.00 & 0.00 & 0.00 & 0.13 & 0.00 \\
\hline 3 & 0.07 & 0.00 & 0.00 & 0.00 & 0.00 & 0.00 & 0.78 & 0.00 & 0.00 & 0.00 & 0.00 & 0.00 \\
\hline 4 & 0.02 & 0.00 & 0.00 & 0.00 & 0.11 & 0.86 & 0.23 & 0.00 & 0.00 & 0.00 & 0.38 & 0.12 \\
\hline 5 & 0.00 & 0.00 & 0.00 & 0.00 & 0.00 & 0.12 & 0.00 & 0.00 & 0.00 & 0.00 & 0.00 & 0.00 \\
\hline 6 & 0.00 & 0.00 & 0.00 & 0.00 & 0.00 & 0.00 & 0.00 & 0.00 & 0.00 & 0.00 & 0.00 & 0.00 \\
\hline 7 & 0.88 & 0.00 & 0.00 & 0.00 & 0.00 & 0.00 & 0.00 & 0.00 & 0.00 & 0.00 & 0.00 & 0.00 \\
\hline 8 & 0.22 & 0.00 & 0.00 & 0.00 & 0.00 & 0.00 & 0.35 & 0.00 & 0.00 & 0.00 & 0.00 & 0.00 \\
\hline 9 & 0.00 & 0.00 & 0.00 & 0.00 & 0.00 & 0.00 & 0.04 & 0.00 & 0.00 & 0.00 & 0.00 & 0.00 \\
\hline 10 & 0.23 & 0.00 & 0.00 & 0.00 & 0.00 & 0.00 & 0.24 & 0.00 & 0.00 & 0.00 & 0.02 & 0.00 \\
\hline 11 & 0.00 & 0.00 & 0.00 & 0.00 & 0.00 & 0.00 & 0.00 & 0.00 & 0.00 & 0.00 & 0.00 & 0.00 \\
\hline 12 & 0.00 & 0.76 & 0.14 & 0.00 & 0.00 & 0.00 & 0.00 & 0.00 & 0.00 & 0.81 & 0.02 & 0.00 \\
\hline 13 & 0.00 & 0.28 & 0.00 & 0.00 & 0.00 & 0.00 & 0.00 & 0.00 & 0.00 & 0.00 & 0.00 & 0.00 \\
\hline 14 & 0.00 & 0.00 & 0.00 & 0.00 & 0.00 & 0.00 & 0.00 & 0.00 & 0.00 & 0.15 & 0.00 & 0.00 \\
\hline 15 & 0.00 & 0.00 & 0.00 & 0.01 & 0.00 & 0.00 & 0.00 & 0.00 & 0.00 & 0.03 & 0.00 & 0.00 \\
\hline 16 & 0.00 & 0.03 & 0.00 & 0.00 & 0.00 & 0.00 & 0.00 & 0.00 & 0.00 & 0.00 & 0.00 & 0.00 \\
\hline 17 & 0.00 & 0.04 & 0.00 & 0.00 & 0.00 & 0.00 & 0.00 & 0.00 & 0.00 & 0.00 & 0.00 & 0.00 \\
\hline 18 & 0.00 & 0.00 & 0.00 & 0.00 & 0.00 & 0.00 & 0.00 & 0.00 & 0.00 & 0.02 & 0.01 & 0.07 \\
\hline 19 & 0.00 & 0.00 & 0.00 & 0.00 & 0.00 & 0.00 & 0.00 & 0.00 & 0.00 & 0.00 & 0.00 & 0.76 \\
\hline 20 & 0.00 & 0.00 & 0.00 & 0.08 & 0.00 & 0.00 & 0.00 & 0.00 & 0.00 & 0.14 & 0.00 & 0.07 \\
\hline 21 & 0.00 & 0.00 & 0.00 & 0.00 & 0.14 & 0.00 & 0.00 & 0.00 & 0.00 & 0.03 & 0.08 & 0.00 \\
\hline 22 & 0.00 & 0.00 & 0.00 & 0.00 & 0.00 & 0.00 & 0.00 & 0.00 & 0.00 & 0.00 & 0.00 & 0.00 \\
\hline 23 & 0.00 & 0.00 & 0.00 & 0.00 & 0.87 & 0.04 & 0.00 & 0.00 & 0.00 & 0.55 & 0.00 & 0.00 \\
\hline 24 & 0.00 & 0.00 & 0.00 & 0.00 & 0.32 & 0.00 & 0.00 & 0.00 & 0.00 & 0.08 & 0.00 & 0.00 \\
\hline 25 & 0.00 & 0.00 & 0.00 & 0.04 & 0.00 & 0.00 & 0.00 & 0.00 & 0.00 & 0.23 & 0.00 & 0.00 \\
\hline 26 & 0.00 & 0.00 & 0.00 & 0.00 & 0.00 & 0.00 & 0.00 & 0.00 & 0.21 & 0.00 & 0.00 & 0.04 \\
\hline 27 & 0.00 & 0.00 & 0.00 & 0.00 & 0.00 & 0.00 & 0.00 & 0.00 & 0.00 & 0.69 & 0.00 & 0.01 \\
\hline 28 & 0.00 & 0.00 & 0.00 & 0.00 & 0.22 & 0.00 & 0.00 & 0.00 & 0.03 & 0.02 & 0.00 & 0.00 \\
\hline 29 & 0.00 & 0.00 & 0.00 & 0.00 & 0.00 & 0.00 & 0.00 & 0.00 & 0.35 & 0.00 & 0.00 & 0.00 \\
\hline 30 & 0.00 & 0.00 & 0.00 & 0.00 & --- & 0.00 & 0.00 & 0.00 & 0.00 & 0.00 & 0.00 & 0.00 \\
\hline 31 & 0.00 & --- & 0.00 & 0.00 & --- & 0.00 & --- & 0.00 & --- & 0.00 & 0.00 & --- \\
\hline TOTAL & 1.42 & 1.11 & 0.14 & 0.13 & 1.75 & 1.12 & 1.94 & 0.00 & 0.59 & 2.75 & 0.64 & 1.07 \\
\hline MAX & 0.88 & 0.76 & 0.14 & 0.08 & 0.87 & 0.86 & 0.78 & 0.00 & 0.35 & 0.81 & 0.38 & 0.76 \\
\hline MIN & 0.00 & 0.00 & 0.00 & 0.00 & 0.00 & 0.00 & 0.00 & 0.00 & 0.00 & 0.00 & 0.00 & 0.00 \\
\hline
\end{tabular}

CAL YR 2003 TOTAL 6.84 MAX 0.88 MIN 0.00

WTR YR 2004 TOTAL 12.66 MAX 0.88 MIN 0.00 


\section{0, CAMPUS WASH RAIN GAGE AT ALBUQUERQUE, NEW MEXICO STATION ANALYSIS \\ WATER YEAR 2004}

Location.--35 $05^{\prime} 38^{\prime \prime} \mathrm{N}, 106^{\circ} 37^{\prime} 25^{\prime \prime} \mathrm{W}$. The rain gage is located in northeast Albuquerque at the surface-water gage, just west of the UNM South Golf Course.

Equipment.--7.9-inch-diameter tipping bucket connected to a surface-water data recorder. The bucket tips one time per 0.01 inch of rain, and the recorder stores data at 5-minute intervals. Rain gage is calibrated approximately every 2 years and was last calibrated in March 2003.

Record.--The rain gage gave a complete and satisfactory record for the entire water year.

Period of Record.--October 1988 to present.

Remarks.--Record is good for the entire water year.

PRECIPITATION, TOTAL, INCHES, WATER YEAR OCTOBER 2003 TO SEPTEMBER 2004 DAILY SUM VALUES

\begin{tabular}{|c|c|c|c|c|c|c|c|c|c|c|c|c|}
\hline DAY & ОСт & Nov & DEC & JAN & FEB & MAR & APR & MAY & JUN & JUL & AUG & SEP \\
\hline 1 & 0.00 & 0.00 & 0.00 & 0.00 & 0.00 & 0.00 & 0.00 & 0.00 & 0.00 & 0.00 & 0.00 & 0.00 \\
\hline 2 & 0.00 & 0.00 & 0.00 & 0.00 & 0.00 & 0.07 & 0.49 & 0.00 & 0.00 & 0.00 & 0.04 & 0.00 \\
\hline 3 & 0.10 & 0.00 & 0.00 & 0.00 & 0.01 & 0.00 & 1.54 & 0.00 & 0.00 & 0.00 & 0.00 & 0.00 \\
\hline 4 & 0.02 & 0.00 & 0.00 & 0.00 & 0.00 & 0.63 & 0.04 & 0.00 & 0.00 & 0.00 & 0.00 & 0.07 \\
\hline 5 & 0.00 & 0.00 & 0.00 & 0.00 & 0.00 & 0.03 & 0.00 & 0.00 & 0.00 & 0.00 & 0.00 & 0.00 \\
\hline 6 & 0.00 & 0.00 & 0.00 & 0.00 & 0.00 & 0.00 & 0.00 & 0.00 & 0.00 & 0.00 & 0.00 & 0.00 \\
\hline 7 & 0.91 & 0.00 & 0.00 & 0.00 & 0.00 & 0.00 & 0.00 & 0.00 & 0.00 & 0.00 & 0.00 & 0.00 \\
\hline 8 & 0.14 & 0.00 & 0.02 & 0.00 & 0.00 & 0.00 & 0.26 & 0.00 & 0.00 & 0.00 & 0.00 & 0.00 \\
\hline 9 & 0.00 & 0.00 & 0.00 & 0.00 & 0.00 & 0.00 & 0.01 & 0.00 & 0.00 & 0.00 & 0.00 & 0.00 \\
\hline 10 & 0.16 & 0.00 & 0.00 & 0.00 & 0.00 & 0.00 & 0.23 & 0.00 & 0.00 & 0.00 & 0.20 & 0.00 \\
\hline 11 & 0.00 & 0.00 & 0.00 & 0.00 & 0.00 & 0.00 & 0.00 & 0.00 & 0.00 & 0.05 & 0.04 & 0.00 \\
\hline 12 & 0.00 & 0.49 & 0.12 & 0.00 & 0.00 & 0.00 & 0.00 & 0.00 & 0.00 & 0.57 & 0.00 & 0.00 \\
\hline 13 & 0.00 & 0.18 & 0.00 & 0.00 & 0.00 & 0.00 & 0.00 & 0.00 & 0.00 & 0.00 & 0.01 & 0.01 \\
\hline 14 & 0.00 & 0.00 & 0.00 & 0.00 & 0.00 & 0.00 & 0.00 & 0.00 & 0.00 & 0.00 & 0.00 & 0.00 \\
\hline 15 & 0.00 & 0.00 & 0.00 & 0.04 & 0.02 & 0.00 & 0.00 & 0.00 & 0.00 & 0.52 & 0.00 & 0.00 \\
\hline 16 & 0.00 & 0.00 & 0.00 & 0.00 & 0.00 & 0.00 & 0.00 & 0.00 & 0.00 & 0.00 & 0.00 & 0.00 \\
\hline 17 & 0.00 & 0.00 & 0.00 & 0.00 & 0.00 & 0.00 & 0.19 & 0.00 & 0.00 & 0.00 & 0.00 & 0.00 \\
\hline 18 & 0.00 & 0.00 & 0.00 & 0.00 & 0.00 & 0.00 & 0.00 & 0.00 & 0.00 & 0.03 & 0.01 & 0.09 \\
\hline 19 & 0.00 & 0.00 & 0.00 & 0.00 & 0.00 & 0.00 & 0.00 & 0.00 & 0.00 & 0.18 & 0.02 & 0.65 \\
\hline 20 & 0.00 & 0.00 & 0.00 & 0.04 & 0.00 & 0.06 & 0.00 & 0.00 & 0.00 & 0.02 & 0.00 & 0.00 \\
\hline 21 & 0.00 & 0.00 & 0.00 & 0.00 & 0.05 & 0.06 & 0.00 & 0.00 & 0.00 & 0.00 & 0.00 & 0.00 \\
\hline 22 & 0.00 & 0.09 & 0.00 & 0.00 & 0.00 & 0.00 & 0.01 & 0.00 & 0.00 & 0.16 & 0.00 & 0.00 \\
\hline 23 & 0.00 & 0.00 & 0.00 & 0.00 & 0.95 & 0.11 & 0.00 & 0.00 & 0.00 & 1.29 & 0.00 & 0.00 \\
\hline 24 & 0.00 & 0.00 & 0.00 & 0.00 & 0.14 & 0.00 & 0.00 & 0.00 & 0.00 & 0.20 & 0.00 & 0.00 \\
\hline 25 & 0.00 & 0.00 & 0.00 & 0.05 & 0.00 & 0.00 & 0.00 & 0.00 & 0.00 & 0.25 & 0.00 & 0.00 \\
\hline 26 & 0.00 & 0.00 & 0.10 & 0.00 & 0.00 & 0.00 & 0.00 & 0.00 & 0.00 & 0.00 & 0.00 & 0.00 \\
\hline 27 & 0.00 & 0.00 & 0.00 & 0.00 & 0.00 & 0.00 & 0.00 & 0.00 & 0.00 & 0.30 & 0.00 & 0.00 \\
\hline 28 & 0.00 & 0.00 & 0.00 & 0.00 & 0.13 & 0.00 & 0.00 & 0.00 & 0.04 & 0.00 & 0.00 & 0.00 \\
\hline 29 & 0.00 & 0.00 & 0.00 & 0.00 & 0.00 & 0.00 & 0.00 & 0.00 & 0.61 & 0.00 & 0.05 & 0.02 \\
\hline 30 & 0.00 & 0.00 & 0.00 & 0.00 & --- & 0.00 & 0.00 & 0.00 & 0.00 & 0.00 & 0.01 & 0.00 \\
\hline 31 & 0.00 & --- & 0.00 & 0.00 & --- & 0.00 & --- & 0.00 & --- & 0.00 & 0.00 & --- \\
\hline TOTAL & 1.33 & 0.76 & 0.24 & 0.13 & 1.30 & 0.96 & 2.77 & 0.00 & 0.65 & 3.57 & 0.38 & 0.84 \\
\hline MAX & 0.91 & 0.49 & 0.12 & 0.05 & 0.95 & 0.63 & 1.54 & 0.00 & 0.61 & 1.29 & 0.20 & 0.65 \\
\hline MIN & 0.00 & 0.00 & 0.00 & 0.00 & 0.00 & 0.00 & 0.00 & 0.00 & 0.00 & 0.00 & 0.00 & 0.00 \\
\hline
\end{tabular}




\section{0, CROWN TOWERS AT NINE MILE HILL RAIN GAGE AT \\ ALBUQUERQUE, NEW MEXICO \\ STATION ANALYSIS \\ WATER YEAR 2004}

Location.--35 $04^{\prime} 00^{\prime \prime} \mathrm{N}, 106^{\circ} 46^{\prime} 56^{\prime \prime} \mathrm{W}$. The rain gage is located in far southwest Albuquerque, and is in the maintenance yard of a group of communications towers. The yard is just southeast of the intersection of Interstate 40 and Paseo del Vulcan Road.

Equipment.--Onset Corporation HOBO Event data recorder and 6.5-inch-diameter tipping bucket. The bucket tips one time per 0.01 inch of rain, and the recorder stores data at 5-minute intervals. Rain gage is calibrated approximately every 2 years and was last calibrated in March 2003.

Record.--The rain gage gave a complete and satisfactory record for the water year.

Period of Record.--August 2000 to present.

Remarks.--Record is good for the water year.

PRECIPITATION, TOTAL, INCHES, WATER YEAR OCTOBER 2003 TO SEPTEMBER 2004 DAILY SUM VALUES

\begin{tabular}{|c|c|c|c|c|c|c|c|c|c|c|c|c|}
\hline DAY & OCT & NOV & DEC & JAN & FEB & MAR & APR & MAY & JUN & JUL & AUG & SEP \\
\hline 1 & 0.00 & 0.08 & 0.00 & 0.00 & 0.00 & 0.00 & 0.00 & 0.00 & 0.00 & 0.00 & 0.00 & 0.00 \\
\hline 2 & 0.00 & 0.00 & 0.00 & 0.00 & 0.00 & 0.13 & 0.59 & 0.00 & 0.00 & 0.00 & 0.09 & 0.00 \\
\hline 3 & 0.13 & 0.00 & 0.00 & 0.00 & 0.00 & 0.11 & 1.58 & 0.00 & 0.00 & 0.00 & 0.01 & 0.01 \\
\hline 4 & 0.01 & 0.00 & 0.00 & 0.00 & 0.00 & 0.50 & 0.20 & 0.00 & 0.00 & 0.00 & 0.05 & 0.20 \\
\hline 5 & 0.00 & 0.00 & 0.00 & 0.00 & 0.00 & 0.01 & 0.00 & 0.00 & 0.00 & 0.00 & 0.09 & 0.00 \\
\hline 6 & 0.00 & 0.00 & 0.00 & 0.00 & 0.00 & 0.00 & 0.00 & 0.00 & 0.00 & 0.00 & 0.00 & 0.00 \\
\hline 7 & 0.48 & 0.00 & 0.00 & 0.00 & 0.00 & 0.00 & 0.02 & 0.00 & 0.00 & 0.00 & 0.00 & 0.00 \\
\hline 8 & 0.18 & 0.00 & 0.02 & 0.00 & 0.00 & 0.00 & 0.26 & 0.00 & 0.00 & 0.03 & 0.00 & 0.00 \\
\hline 9 & 0.00 & 0.00 & 0.00 & 0.00 & 0.00 & 0.00 & 0.00 & 0.00 & 0.00 & 0.00 & 0.00 & 0.00 \\
\hline 10 & 0.22 & 0.02 & 0.00 & 0.00 & 0.00 & 0.00 & 0.43 & 0.00 & 0.00 & 0.00 & 0.11 & 0.00 \\
\hline 11 & 0.01 & 0.00 & 0.00 & 0.00 & 0.00 & 0.00 & 0.04 & 0.00 & 0.00 & 0.00 & 0.00 & 0.00 \\
\hline 12 & 0.00 & 0.58 & 0.12 & 0.00 & 0.00 & 0.00 & 0.00 & 0.00 & 0.00 & 0.05 & 0.00 & 0.00 \\
\hline 13 & 0.00 & 0.16 & 0.00 & 0.00 & 0.00 & 0.00 & 0.00 & 0.00 & 0.00 & 0.00 & 0.00 & 0.00 \\
\hline 14 & 0.00 & 0.01 & 0.00 & 0.00 & 0.00 & 0.00 & 0.00 & 0.00 & 0.00 & 0.00 & 0.00 & 0.00 \\
\hline 15 & 0.00 & 0.01 & 0.00 & 0.09 & 0.00 & 0.00 & 0.00 & 0.00 & 0.00 & 0.04 & 0.10 & 0.00 \\
\hline 16 & 0.00 & 0.00 & 0.00 & 0.02 & 0.00 & 0.00 & 0.00 & 0.00 & 0.00 & 0.00 & 0.00 & 0.00 \\
\hline 17 & 0.00 & 0.01 & 0.00 & 0.01 & 0.00 & 0.00 & 0.00 & 0.00 & 0.00 & 0.00 & 0.00 & 0.00 \\
\hline 18 & 0.00 & 0.00 & 0.00 & 0.00 & 0.00 & 0.00 & 0.00 & 0.00 & 0.00 & 0.04 & 0.01 & 0.19 \\
\hline 19 & 0.00 & 0.00 & 0.00 & 0.00 & 0.00 & 0.00 & 0.00 & 0.00 & 0.00 & 0.10 & 0.04 & 0.39 \\
\hline 20 & 0.00 & 0.00 & 0.00 & 0.11 & 0.00 & 0.00 & 0.00 & 0.00 & 0.00 & 0.09 & 0.01 & 0.03 \\
\hline 21 & 0.00 & 0.00 & 0.00 & 0.01 & 0.14 & 0.00 & 0.00 & 0.00 & 0.00 & 0.04 & 0.00 & 0.00 \\
\hline 22 & 0.00 & 0.00 & 0.00 & 0.00 & 0.01 & 0.00 & 0.00 & 0.00 & 0.03 & 0.12 & 0.00 & 0.00 \\
\hline 23 & 0.00 & 0.00 & 0.00 & 0.00 & 0.39 & 0.03 & 0.03 & 0.00 & 0.00 & 0.11 & 0.00 & 0.00 \\
\hline 24 & 0.00 & 0.00 & 0.00 & 0.00 & 0.53 & 0.00 & 0.00 & 0.00 & 0.00 & 1.31 & 0.00 & 0.00 \\
\hline 25 & 0.00 & 0.00 & 0.00 & 0.00 & 0.02 & 0.00 & 0.00 & 0.00 & 0.00 & 0.26 & 0.00 & 0.00 \\
\hline 26 & 0.00 & 0.00 & 0.01 & 0.00 & 0.00 & 0.00 & 0.00 & 0.00 & 0.00 & 0.00 & 0.00 & 0.00 \\
\hline 27 & 0.00 & 0.00 & 0.00 & 0.00 & 0.00 & 0.00 & 0.00 & 0.00 & 0.00 & 0.05 & 0.00 & 0.00 \\
\hline 28 & 0.00 & 0.00 & 0.00 & 0.00 & 0.05 & 0.00 & 0.00 & 0.00 & 0.00 & 0.00 & 0.00 & 0.00 \\
\hline 29 & 0.00 & 0.00 & 0.00 & 0.00 & 0.00 & 0.00 & 0.00 & 0.00 & 0.65 & 0.00 & 0.21 & 0.14 \\
\hline 30 & 0.00 & 0.00 & 0.00 & 0.00 & --- & 0.00 & 0.00 & 0.00 & 0.00 & 0.00 & 0.00 & 0.04 \\
\hline 31 & 0.00 & --- & 0.00 & 0.00 & --- & 0.00 & --- & 0.00 & --- & 0.00 & 0.00 & --- \\
\hline TOTAL & 1.03 & 0.87 & 0.15 & 0.24 & 1.14 & 0.78 & 3.15 & 0.00 & 0.68 & 2.24 & 0.72 & 1.00 \\
\hline MAX & 0.48 & 0.58 & 0.12 & 0.11 & 0.53 & 0.50 & 1.58 & 0.00 & 0.65 & 1.31 & 0.21 & 0.39 \\
\hline MIN & 0.00 & 0.00 & 0.00 & 0.00 & 0.00 & 0.00 & 0.00 & 0.00 & 0.00 & 0.00 & 0.00 & 0.00 \\
\hline
\end{tabular}




\section{0, ELENA GALLEGOS PICNIC AREA RAIN GAGE AT \\ ALBUQUERQUE, NEW MEXICO \\ STATION ANALYSIS \\ WATER YEAR 2004}

Location.--35 $09^{\prime} 42^{\prime} \mathrm{N}, 106^{\circ} 28^{\prime} 25^{\prime} \mathrm{W}$. The rain gage is located in the Sandia Mountains foothills on the roof of the Elena Gallegos visitor center, approximately one mile northeast of the intersection of Tramway Boulevard and Academy Road.

Equipment.--Onset Corporation HOBO Event data recorder and 8.0-inch-diameter tipping bucket. The bucket tips one time per 0.01 inch of rain, and the recorder stores data at 5-minute intervals. Rain gage is calibrated approximately every 2 years and was last calibrated in March 2003.

Record.--The rain gage gave a complete and satisfactory record for the entire water year.

Period of Record.--October 1994 to present.

Remarks.--Record is good for the entire water year.

PRECIPITATION, TOTAL, INCHES, WATER YEAR OCTOBER 2003 TO SEPTEMBER 2004 DAILY SUM VALUES

\begin{tabular}{|c|c|c|c|c|c|c|c|c|c|c|c|c|}
\hline DAY & OCT & NOV & DEC & JAN & FEB & MAR & APR & MAY & JUN & JUL & AUG & SEP \\
\hline 1 & 0.01 & 0.00 & 0.00 & 0.00 & 0.14 & 0.00 & 0.00 & 0.00 & 0.00 & 0.00 & 0.00 & 0.00 \\
\hline 2 & 0.0 & 0.00 & 0.00 & 0.00 & 0.00 & 0.05 & 0.41 & 0.00 & 0.00 & 0.00 & 0.16 & 0.00 \\
\hline 3 & 0.12 & 0.00 & 0.00 & 0.00 & 0.00 & 0.00 & 0.99 & 0.00 & 0.00 & 0.00 & 0.00 & 0.00 \\
\hline 4 & 0.05 & 0.00 & 0.00 & 0.00 & 0.05 & 0.68 & 0.10 & 0.00 & 0.00 & 0.00 & 1.47 & 0.12 \\
\hline 5 & 0.0 & 0.00 & 0.00 & 0.00 & 0.00 & 0.41 & 0.00 & 0.00 & 0.00 & 0.00 & 0.01 & 0.00 \\
\hline 6 & 0.0 & 0.00 & 0.00 & 0.00 & 0.00 & 0.00 & 0.00 & 0.00 & 0.00 & 0.00 & 0.34 & 0.00 \\
\hline 7 & 0.49 & 0.00 & 0.00 & 0.00 & 0.00 & 0.00 & 0.00 & 0.00 & 0.00 & 0.00 & 0.00 & 0.00 \\
\hline 8 & 0.17 & 0.00 & 0.02 & 0.00 & 0.00 & 0.00 & 0.36 & 0.00 & 0.00 & 0.00 & 0.00 & 0.00 \\
\hline 9 & 0.00 & 0.00 & 0.03 & 0.00 & 0.00 & 0.00 & 0.11 & 0.00 & 0.00 & 0.00 & 0.00 & 0.00 \\
\hline 10 & 0.30 & 0.01 & 0.00 & 0.00 & 0.00 & 0.00 & 0.04 & 0.00 & 0.00 & 0.00 & 0.02 & 0.00 \\
\hline 11 & 0.00 & 0.00 & 0.00 & 0.00 & 0.00 & 0.00 & 0.00 & 0.00 & 0.00 & 0.05 & 0.01 & 0.00 \\
\hline 12 & 0.00 & 0.42 & 0.23 & 0.00 & 0.00 & 0.00 & 0.00 & 0.00 & 0.00 & 0.00 & 0.00 & 0.00 \\
\hline 13 & 0.00 & 0.15 & 0.00 & 0.00 & 0.00 & 0.00 & 0.00 & 0.00 & 0.00 & 0.00 & 0.02 & 0.00 \\
\hline 14 & 0.00 & 0.01 & 0.00 & 0.00 & 0.00 & 0.00 & 0.00 & 0.00 & 0.00 & 0.03 & 0.21 & 0.00 \\
\hline 15 & 0.00 & 0.00 & 0.00 & 0.10 & 0.00 & 0.00 & 0.00 & 0.00 & 0.00 & 0.00 & 0.00 & 0.00 \\
\hline 16 & 0.00 & 0.04 & 0.00 & 0.00 & 0.00 & 0.00 & 0.00 & 0.00 & 0.00 & 0.00 & 0.00 & 0.00 \\
\hline 17 & 0.00 & 0.03 & 0.00 & 0.01 & 0.00 & 0.00 & 0.01 & 0.00 & 0.00 & 0.00 & 0.00 & 0.00 \\
\hline 18 & 0.00 & 0.00 & 0.00 & 0.00 & 0.00 & 0.00 & 0.00 & 0.00 & 0.00 & 0.02 & 0.01 & 0.04 \\
\hline 19 & 0.00 & 0.00 & 0.00 & 0.00 & 0.00 & 0.00 & 0.00 & 0.00 & 0.00 & 0.13 & 0.09 & 0.77 \\
\hline 20 & 0.00 & 0.00 & 0.00 & 0.11 & 0.00 & 0.00 & 0.00 & 0.00 & 0.00 & 0.20 & 0.01 & 0.09 \\
\hline 21 & 0.00 & 0.00 & 0.00 & 0.01 & 0.16 & 0.00 & 0.00 & 0.00 & 0.00 & 0.00 & 0.02 & 0.00 \\
\hline 22 & 0.00 & 0.00 & 0.02 & 0.00 & 0.00 & 0.00 & 0.00 & 0.00 & 0.00 & 0.76 & 0.00 & 0.00 \\
\hline 23 & 0.00 & 0.00 & 0.00 & 0.00 & 0.34 & 0.06 & 0.00 & 0.00 & 0.00 & 0.31 & 0.00 & 0.00 \\
\hline 24 & 0.00 & 0.00 & 0.00 & 0.00 & 0.41 & 0.01 & 0.00 & 0.00 & 0.00 & 0.78 & 0.00 & 0.00 \\
\hline 25 & 0.00 & 0.00 & 0.00 & 0.11 & 0.44 & 0.00 & 0.00 & 0.00 & 0.02 & 0.12 & 0.00 & 0.00 \\
\hline 26 & 0.00 & 0.00 & 0.00 & 0.00 & 0.00 & 0.00 & 0.00 & 0.00 & 0.10 & 0.00 & 0.00 & 0.03 \\
\hline 27 & 0.00 & 0.00 & 0.00 & 0.00 & 0.00 & 0.00 & 0.00 & 0.00 & 0.00 & 0.42 & 0.00 & 0.00 \\
\hline 28 & 0.00 & 0.00 & 0.00 & 0.00 & 0.25 & 0.00 & 0.00 & 0.00 & 0.09 & 0.02 & 0.00 & 0.00 \\
\hline 29 & 0.00 & 0.00 & 0.00 & 0.00 & 0.03 & 0.00 & 0.00 & 0.00 & 0.47 & 0.00 & 0.00 & 0.00 \\
\hline 30 & 0.00 & 0.00 & 0.00 & 0.00 & --- & 0.00 & 0.00 & 0.00 & 0.00 & 0.00 & 0.00 & 0.00 \\
\hline 31 & 0.00 & --- & 0.00 & 0.00 & --- & 0.00 & --- & 0.00 & --- & 0.00 & 0.00 & --- \\
\hline TOTAL & 1.14 & 0.66 & 0.30 & 0.34 & 1.82 & 1.21 & 2.02 & 0.00 & 0.68 & 2.84 & 2.37 & 1.05 \\
\hline MAX & 0.49 & 0.42 & 0.23 & 0.11 & 0.44 & 0.68 & 0.99 & 0.00 & 0.47 & 0.78 & 1.47 & 0.77 \\
\hline MIN & 0.00 & 0.00 & 0.00 & 0.00 & 0.00 & 0.00 & 0.00 & 0.00 & 0.00 & 0.00 & 0.00 & 0.00 \\
\hline
\end{tabular}

CAL YR 2003 TOTAL 7.57 MAX 0.57 MIN 0.00

WTR YR 2004 TOTAL 14.43 MAX 1.47 MIN 0.00 


\section{0, EMBUDO CANYON RAIN GAGE AT ALBUQUERQUE, NEW MEXICO \\ STATION ANALYSIS \\ WATER YEAR 2004}

Location.-- $35^{\circ} 05^{\prime} 55^{\prime} \mathrm{N}, 106^{\circ} 28^{\prime} 32^{\prime}$ 'W. The rain gage is located in the Sandia Mountains foothills in Embudo Canyon. The city maintains a water storage tank approximately 0.5 mile east of the eastern terminus of Indian School Road, and the rain gage is located in the storage tank yard.

Equipment.--Onset Corporation HOBO Event data recorder and 6.3-inch-diameter tipping bucket. The bucket tips one time per 0.01 inch of rain, and the recorder stores data at 5 -minute intervals. Rain gage is calibrated approximately every 2 years and was last calibrated in March 2003.

Record.--The rain gage gave a complete and satisfactory record for the entire water year.

Period of Record.--June 1999 to present.

Remarks.--Record is good for the entire water year.

PRECIPITATION, TOTAL, INCHES, WATER YEAR OCTOBER 2003 TO SEPTEMBER 2004 DAILY SUM VALUES

\begin{tabular}{|c|c|c|c|c|c|c|c|c|c|c|c|c|}
\hline DAY & OCT & NOV & DEC & JAN & FEB & MAR & APR & MAY & JUN & JUL & AUG & SEP \\
\hline 1 & 0.02 & 0.00 & 0.00 & 0.00 & 0.13 & 0.00 & 0.00 & 0.00 & 0.00 & 0.00 & 0.00 & 0.00 \\
\hline 2 & 0.00 & 0.00 & 0.00 & 0.00 & 0.02 & 0.11 & 0.42 & 0.00 & 0.00 & 0.00 & 0.18 & 0.00 \\
\hline 3 & 0.08 & 0.00 & 0.00 & 0.00 & 0.00 & 0.00 & 1.63 & 0.00 & 0.00 & 0.00 & 0.00 & 0.00 \\
\hline 4 & 0.01 & 0.00 & 0.00 & 0.00 & 0.04 & 0.82 & 0.55 & 0.00 & 0.00 & 0.00 & 1.40 & 0.16 \\
\hline 5 & 0.00 & 0.00 & 0.00 & 0.00 & 0.00 & 0.17 & 0.00 & 0.00 & 0.00 & 0.00 & 0.00 & 0.00 \\
\hline 6 & 0.00 & 0.00 & 0.00 & 0.00 & 0.00 & 0.00 & 0.01 & 0.00 & 0.00 & 0.00 & 0.04 & 0.00 \\
\hline 7 & 0.62 & 0.00 & 0.00 & 0.00 & 0.00 & 0.00 & 0.00 & 0.00 & 0.00 & 0.00 & 0.00 & 0.00 \\
\hline 8 & 0.18 & 0.00 & 0.01 & 0.00 & 0.00 & 0.00 & 0.39 & 0.00 & 0.00 & 0.00 & 0.00 & 0.00 \\
\hline 9 & 0.00 & 0.00 & 0.03 & 0.00 & 0.00 & 0.00 & 0.06 & 0.00 & 0.00 & 0.00 & 0.00 & 0.00 \\
\hline 10 & 0.21 & 0.00 & 0.00 & 0.00 & 0.00 & 0.00 & 0.10 & 0.00 & 0.00 & 0.00 & 0.01 & 0.00 \\
\hline 11 & 0.00 & 0.01 & 0.00 & 0.00 & 0.00 & 0.00 & 0.07 & 0.00 & 0.00 & 0.08 & 0.00 & 0.00 \\
\hline 12 & 0.00 & 0.61 & 0.13 & 0.00 & 0.00 & 0.00 & 0.00 & 0.00 & 0.00 & 0.00 & 0.00 & 0.00 \\
\hline 13 & 0.00 & 0.25 & 0.03 & 0.00 & 0.00 & 0.00 & 0.00 & 0.00 & 0.00 & 0.00 & 0.00 & 0.00 \\
\hline 14 & 0.00 & 0.00 & 0.00 & 0.00 & 0.00 & 0.00 & 0.00 & 0.00 & 0.00 & 0.45 & 0.01 & 0.00 \\
\hline 15 & 0.00 & 0.00 & 0.00 & 0.12 & 0.00 & 0.00 & 0.00 & 0.00 & 0.00 & 0.00 & 0.00 & 0.00 \\
\hline 16 & 0.00 & 0.00 & 0.00 & 0.00 & 0.00 & 0.00 & 0.00 & 0.00 & 0.00 & 0.00 & 0.00 & 0.00 \\
\hline 17 & 0.00 & 0.01 & 0.00 & 0.02 & 0.00 & 0.00 & 0.00 & 0.00 & 0.00 & 0.00 & 0.00 & 0.00 \\
\hline 18 & 0.00 & 0.00 & 0.00 & 0.00 & 0.00 & 0.00 & 0.00 & 0.00 & 0.00 & 0.00 & 0.00 & 0.08 \\
\hline 19 & 0.00 & 0.00 & 0.00 & 0.00 & 0.00 & 0.00 & 0.00 & 0.00 & 0.00 & 0.00 & 0.04 & 0.68 \\
\hline 20 & 0.00 & 0.00 & 0.00 & 0.15 & 0.00 & 0.00 & 0.00 & 0.00 & 0.00 & 0.16 & 0.00 & 0.19 \\
\hline 21 & 0.00 & 0.00 & 0.00 & 0.00 & 0.14 & 0.00 & 0.00 & 0.00 & 0.00 & 0.00 & 0.03 & 0.00 \\
\hline 22 & 0.00 & 0.00 & 0.00 & 0.00 & 0.00 & 0.00 & 0.00 & 0.00 & 0.01 & 0.08 & 0.04 & 0.00 \\
\hline 23 & 0.00 & 0.00 & 0.00 & 0.00 & 1.02 & 0.06 & 0.01 & 0.00 & 0.00 & 0.30 & 0.00 & 0.00 \\
\hline 24 & 0.00 & 0.00 & 0.00 & 0.00 & 0.36 & 0.00 & 0.00 & 0.00 & 0.00 & 0.31 & 0.00 & 0.00 \\
\hline 25 & 0.00 & 0.00 & 0.00 & 0.04 & 0.07 & 0.00 & 0.00 & 0.00 & 0.00 & 0.27 & 0.00 & 0.00 \\
\hline 26 & 0.00 & 0.00 & 0.00 & 0.01 & 0.00 & 0.00 & 0.00 & 0.00 & 0.14 & 0.00 & 0.00 & 0.00 \\
\hline 27 & 0.00 & 0.00 & 0.00 & 0.02 & 0.00 & 0.00 & 0.00 & 0.00 & 0.00 & 0.19 & 0.00 & 0.00 \\
\hline 28 & 0.00 & 0.00 & 0.00 & 0.00 & 0.23 & 0.00 & 0.00 & 0.00 & 0.97 & 0.01 & 0.00 & 0.00 \\
\hline 29 & 0.00 & 0.00 & 0.00 & 0.00 & 0.02 & 0.00 & 0.00 & 0.00 & 0.41 & 0.00 & 0.00 & 0.00 \\
\hline 30 & 0.00 & 0.00 & 0.00 & 0.00 & --- & 0.00 & 0.00 & 0.00 & 0.00 & 0.00 & 0.00 & 0.01 \\
\hline 31 & 0.00 & --- & 0.00 & 0.00 & --- & 0.00 & --- & 0.00 & --- & 0.00 & 0.00 & --- \\
\hline TOTAL & 1.12 & 0.88 & 0.20 & 0.36 & 2.03 & 1.16 & 3.24 & 0.00 & 1.53 & 1.85 & 1.75 & 1.12 \\
\hline MAX & 0.62 & 0.61 & 0.13 & 0.15 & 1.02 & 0.82 & 1.63 & 0.00 & 0.97 & 0.45 & 1.40 & 0.68 \\
\hline MIN & 0.00 & 0.00 & 0.00 & 0.00 & 0.00 & 0.00 & 0.00 & 0.00 & 0.00 & 0.00 & 0.00 & 0.00 \\
\hline
\end{tabular}

CAL YR 2003 TOTAL 8.14 MAX 0.86 MIN 0.00

WTR YR 2004 TOTAL 15.24 MAX 1.63 MIN 0.00 


\section{0, EMERGENCY DISPATCH BUILDING RAIN GAGE AT ALBUQUERQUE, NEW MEXICO \\ STATION ANALYSIS \\ WATER YEAR 2004}

Location.-- $35^{\circ} 03^{\prime} 48^{\prime \prime} \mathrm{N}, 106^{\circ} 45^{\prime} 32^{\prime \prime} \mathrm{W}$. The rain gage is located in southwest Albuquerque in the Emergency Response Dispatch Building. The building is located near the intersection of Central Avenue and 98th Street.

Equipment.-- Onset Corporation HOBO Event data recorder and 6.5-inch-diameter tipping bucket. The bucket tips one time per 0.01 inch of rain, and the recorder stores data at 5-minute intervals. Rain gage is calibrated approximately every 2 years and was last calibrated in March 2003.

Record.--The rain gage gave a complete and satisfactory record for the entire water year.

Period of Record.--October 2000 to present.

Remarks.--Record is good for the entire water year.

PRECIPITATION, TOTAL, INCHES, WATER YEAR OCTOBER 2003 TO SEPTEMBER 2004 DAILY SUM VALUES

\begin{tabular}{|c|c|c|c|c|c|c|c|c|c|c|c|c|}
\hline DAY & ост & NOV & DEC & JAN & FEB & MAR & APR & MAY & JUN & JUL & AUG & SEP \\
\hline 1 & 0.00 & 0.02 & 0.00 & 0.00 & 0.00 & 0.00 & 0.00 & 0.00 & 0.00 & 0.00 & 0.00 & 0.00 \\
\hline 2 & 0.00 & 0.00 & 0.00 & 0.00 & 0.00 & 0.19 & 0.48 & 0.00 & 0.00 & 0.00 & 0.06 & 0.00 \\
\hline 3 & 0.12 & 0.00 & 0.00 & 0.00 & 0.05 & 0.02 & 1.68 & 0.00 & 0.00 & 0.00 & 0.01 & 0.01 \\
\hline 4 & 0.01 & 0.00 & 0.00 & 0.00 & 0.00 & 0.66 & 0.17 & 0.00 & 0.01 & 0.00 & 0.01 & 0.17 \\
\hline 5 & 0.00 & 0.00 & 0.00 & 0.00 & 0.00 & 0.00 & 0.00 & 0.00 & 0.00 & 0.00 & 0.09 & 0.00 \\
\hline 6 & 0.00 & 0.00 & 0.00 & 0.00 & 0.00 & 0.00 & 0.00 & 0.00 & 0.00 & 0.00 & 0.00 & 0.00 \\
\hline 7 & 0.53 & 0.00 & 0.00 & 0.00 & 0.00 & 0.00 & 0.01 & 0.00 & 0.00 & 0.00 & 0.00 & 0.00 \\
\hline 8 & 0.22 & 0.00 & 0.03 & 0.00 & 0.00 & 0.00 & 0.25 & 0.00 & 0.00 & 0.02 & 0.00 & 0.00 \\
\hline 9 & 0.00 & 0.00 & 0.00 & 0.00 & 0.00 & 0.00 & 0.01 & 0.00 & 0.00 & 0.00 & 0.00 & 0.00 \\
\hline 10 & 0.38 & 0.02 & 0.00 & 0.00 & 0.00 & 0.00 & 0.42 & 0.00 & 0.00 & 0.00 & 0.11 & 0.00 \\
\hline 11 & 0.01 & 0.00 & 0.00 & 0.00 & 0.00 & 0.00 & 0.02 & 0.01 & 0.00 & 0.00 & 0.00 & 0.00 \\
\hline 12 & 0.00 & 0.66 & 0.14 & 0.00 & 0.00 & 0.00 & 0.00 & 0.00 & 0.00 & 0.08 & 0.00 & 0.00 \\
\hline 13 & 0.00 & 0.18 & 0.00 & 0.00 & 0.00 & 0.00 & 0.00 & 0.00 & 0.00 & 0.00 & 0.04 & 0.00 \\
\hline 14 & 0.00 & 0.00 & 0.00 & 0.00 & 0.00 & 0.00 & 0.00 & 0.00 & 0.00 & 0.00 & 0.00 & 0.00 \\
\hline 15 & 0.00 & 0.02 & 0.00 & 0.09 & 0.00 & 0.00 & 0.00 & 0.00 & 0.00 & 0.39 & 0.13 & 0.00 \\
\hline 16 & 0.00 & 0.00 & 0.00 & 0.02 & 0.00 & 0.00 & 0.00 & 0.00 & 0.00 & 0.00 & 0.00 & 0.00 \\
\hline 17 & 0.00 & 0.01 & 0.00 & 0.01 & 0.00 & 0.00 & 0.00 & 0.00 & 0.00 & 0.00 & 0.00 & 0.00 \\
\hline 18 & 0.00 & 0.00 & 0.00 & 0.00 & 0.00 & 0.00 & 0.00 & 0.00 & 0.00 & 0.06 & 0.00 & 0.19 \\
\hline 19 & 0.00 & 0.00 & 0.00 & 0.00 & 0.00 & 0.00 & 0.00 & 0.00 & 0.00 & 0.07 & 0.04 & 0.42 \\
\hline 20 & 0.00 & 0.00 & 0.00 & 0.10 & 0.00 & 0.00 & 0.00 & 0.00 & 0.00 & 0.15 & 0.02 & 0.07 \\
\hline 21 & 0.00 & 0.00 & 0.00 & 0.00 & 0.07 & 0.00 & 0.00 & 0.00 & 0.00 & 0.06 & 0.00 & 0.00 \\
\hline 22 & 0.00 & 0.48 & 0.00 & 0.01 & 0.01 & 0.00 & 0.00 & 0.00 & 0.01 & 0.19 & 0.00 & 0.00 \\
\hline 23 & 0.00 & 0.00 & 0.00 & 0.00 & 0.40 & 0.02 & 0.02 & 0.00 & 0.00 & 0.14 & 0.00 & 0.00 \\
\hline 24 & 0.00 & 0.00 & 0.00 & 0.00 & 0.41 & 0.00 & 0.00 & 0.00 & 0.00 & 1.57 & 0.00 & 0.00 \\
\hline 25 & 0.00 & 0.00 & 0.00 & 0.01 & 0.01 & 0.00 & 0.00 & 0.00 & 0.00 & 0.30 & 0.00 & 0.00 \\
\hline 26 & 0.00 & 0.00 & 0.00 & 0.00 & 0.00 & 0.00 & 0.00 & 0.00 & 0.00 & 0.00 & 0.00 & 0.00 \\
\hline 27 & 0.00 & 0.00 & 0.00 & 0.00 & 0.00 & 0.00 & 0.00 & 0.00 & 0.00 & 0.04 & 0.00 & 0.00 \\
\hline 28 & 0.00 & 0.00 & 0.00 & 0.00 & 0.08 & 0.00 & 0.00 & 0.00 & 0.00 & 0.01 & 0.00 & 0.00 \\
\hline 29 & 0.00 & 0.00 & 0.00 & 0.00 & 0.00 & 0.00 & 0.00 & 0.00 & 0.60 & 0.00 & 0.49 & 0.02 \\
\hline 30 & 0.00 & 0.00 & 0.00 & 0.00 & --- & 0.00 & 0.00 & 0.00 & 0.00 & 0.00 & 0.00 & 0.04 \\
\hline 31 & 0.00 & --- & 0.00 & 0.00 & --- & 0.00 & --- & 0.00 & --- & 0.00 & 0.00 & --- \\
\hline TOTAL & 1.27 & 1.39 & 0.17 & 0.24 & 1.03 & 0.89 & 3.06 & 0.01 & 0.62 & 3.08 & 1.00 & 0.92 \\
\hline MAX & 0.53 & 0.66 & 0.14 & 0.10 & 0.41 & 0.66 & 1.68 & 0.01 & 0.60 & 1.57 & 0.49 & 0.42 \\
\hline MIN & 0.00 & 0.00 & 0.00 & 0.00 & 0.00 & 0.00 & 0.00 & 0.00 & 0.00 & 0.00 & 0.00 & 0.00 \\
\hline
\end{tabular}




\section{0, FIRE STATION \#14 RAIN GAGE IN ALBUQUERQUE, NEW MEXICO STATION ANALYSIS \\ WATER YEAR 2004}

Location.-- $35^{\circ} 03^{\prime} 57^{\prime \prime} \mathrm{N}, 106^{\circ} 44^{\prime} 31^{\prime \prime} \mathrm{W}$. The rain gage is located in southwest Albuquerque, approximately 0.25 mile southwest from the intersection of Central Avenue and 98th Street.

Equipment.--Onset Corporation HOBO Event data recorder and 7.9-inch-diameter tipping bucket. The bucket tips one time per 0.01 inch of rain, and the recorder stores data at 5 -minute intervals. Rain gage is calibrated approximately every 2 years and was last calibrated in March 2003.

Record.--The rain gage gave a complete and satisfactory record for the water year except for October 25, October 29 and 30, December 26 to 28, March 11, and March 20 to 21. Although the Firestation \#14 rain gage recorded substantial rain on these days, no precipitation or streamflow was recorded at other gages in the metropolitan area. For this reason, the record for these days should be considered suspect.

Period of Record.--October 1994 to present.

Remarks.--Record is good for the entire water year except for some suspect days in the period of October 25 to March 11.

PRECIPITATION, TOTAL, INCHES, WATER YEAR OCTOBER 2003 TO SEPTEMBER 2004 DAILY SUM VALUES

\begin{tabular}{|c|c|c|c|c|c|c|c|c|c|c|c|c|}
\hline DAY & OCT & NOV & DEC & JAN & FEB & MAR & APR & MAY & JUN & JUL & AUG & SEP \\
\hline 1 & 0.00 & 0.00 & 0.00 & 0.00 & 0.00 & 0.00 & 0.00 & 0.00 & 0.00 & 0.00 & 0.00 & 0.00 \\
\hline 2 & 0.00 & 0.00 & 0.00 & 0.00 & 0.00 & 0.15 & 0.52 & 0.00 & 0.00 & 0.00 & 0.11 & 0.00 \\
\hline 3 & 0.09 & 0.00 & 0.00 & 0.00 & 0.06 & 0.00 & 1.36 & 0.00 & 0.00 & 0.00 & 0.00 & 0.00 \\
\hline 4 & 0.01 & 0.00 & 0.00 & 0.00 & 0.00 & 0.70 & 0.15 & 0.00 & 0.00 & 0.00 & 0.00 & 0.10 \\
\hline 5 & 0.00 & 0.00 & 0.00 & 0.00 & 0.00 & 0.00 & 0.00 & 0.00 & 0.00 & 0.00 & 0.03 & 0.00 \\
\hline 6 & 0.00 & 0.00 & 0.00 & 0.00 & 0.00 & 0.00 & 0.00 & 0.00 & 0.00 & 0.00 & 0.00 & 0.00 \\
\hline 7 & 0.55 & 0.00 & 0.00 & 0.00 & 0.00 & 0.00 & 0.00 & 0.00 & 0.00 & 0.00 & 0.00 & 0.00 \\
\hline 8 & 0.21 & 0.00 & 0.03 & 0.00 & 0.00 & 0.00 & 0.27 & 0.00 & 0.00 & 0.00 & 0.00 & 0.00 \\
\hline 9 & 0.00 & 0.00 & 0.00 & 0.00 & 0.00 & 0.00 & 0.00 & 0.00 & 0.00 & 0.00 & 0.00 & 0.00 \\
\hline 10 & 0.45 & 0.00 & 0.00 & 0.00 & 0.00 & 0.00 & 0.37 & 0.00 & 0.00 & 0.00 & 0.18 & 0.00 \\
\hline 11 & 0.00 & 0.00 & 0.00 & 0.00 & 0.00 & 0.07 & 0.00 & 0.00 & 0.00 & 0.00 & 0.00 & 0.00 \\
\hline 12 & 0.00 & 0.54 & 0.14 & 0.00 & 0.00 & 0.00 & 0.00 & 0.00 & 0.00 & 0.07 & 0.00 & 0.00 \\
\hline 13 & 0.00 & 0.10 & 0.00 & 0.00 & 0.00 & 0.00 & 0.00 & 0.00 & 0.00 & 0.00 & 0.05 & 0.00 \\
\hline 14 & 0.00 & 0.00 & 0.00 & 0.00 & 0.00 & 0.00 & 0.00 & 0.00 & 0.00 & 0.00 & 0.00 & 0.00 \\
\hline 15 & 0.00 & 0.00 & 0.03 & 0.07 & 0.00 & 0.00 & 0.00 & 0.00 & 0.00 & 0.48 & 0.07 & 0.00 \\
\hline 16 & 0.00 & 0.00 & 0.00 & 0.00 & 0.00 & 0.00 & 0.00 & 0.00 & 0.00 & 0.00 & 0.00 & 0.00 \\
\hline 17 & 0.00 & 0.00 & 0.00 & 0.00 & 0.00 & 0.00 & 0.00 & 0.00 & 0.00 & 0.00 & 0.00 & 0.00 \\
\hline 18 & 0.00 & 0.00 & 0.00 & 0.00 & 0.00 & 0.00 & 0.00 & 0.00 & 0.00 & 0.03 & 0.01 & 0.18 \\
\hline 19 & 0.00 & 0.00 & 0.00 & 0.00 & 0.00 & 0.00 & 0.00 & 0.00 & 0.00 & 0.03 & 0.01 & 0.44 \\
\hline 20 & 0.00 & 0.00 & 0.00 & 0.07 & 0.00 & 0.17 & 0.00 & 0.00 & 0.00 & 0.16 & 0.03 & 0.05 \\
\hline 21 & 0.00 & 0.00 & 0.00 & 0.00 & 0.05 & 0.07 & 0.00 & 0.00 & 0.00 & 0.04 & 0.00 & 0.00 \\
\hline 22 & 0.00 & 0.05 & 0.00 & 0.00 & 0.00 & 0.00 & 0.00 & 0.00 & 0.00 & 0.32 & 0.00 & 0.00 \\
\hline 23 & 0.00 & 0.00 & 0.00 & 0.00 & 0.49 & 0.01 & 0.01 & 0.00 & 0.00 & 0.12 & 0.00 & 0.00 \\
\hline 24 & 0.00 & 0.00 & 0.00 & 0.00 & 0.37 & 0.00 & 0.00 & 0.00 & 0.00 & 0.96 & 0.00 & 0.00 \\
\hline 25 & 0.20 & 0.00 & 0.00 & 0.00 & 0.00 & 0.00 & 0.00 & 0.00 & 0.00 & 0.31 & 0.00 & 0.00 \\
\hline 26 & 0.00 & 0.02 & 0.07 & 0.00 & 0.00 & 0.00 & 0.00 & 0.00 & 0.00 & 0.00 & 0.00 & 0.00 \\
\hline 27 & 0.00 & 0.00 & 0.10 & 0.00 & 0.00 & 0.00 & 0.00 & 0.00 & 0.00 & 0.07 & 0.00 & 0.00 \\
\hline 28 & 0.00 & 0.00 & 0.01 & 0.00 & 0.06 & 0.00 & 0.00 & 0.00 & 0.00 & 0.00 & 0.00 & 0.00 \\
\hline 29 & 0.05 & 0.00 & 0.00 & 0.00 & 0.00 & 0.00 & 0.00 & 0.00 & 0.38 & 0.00 & 0.25 & 0.01 \\
\hline 30 & 0.01 & 0.00 & 0.00 & 0.00 & --- & 0.00 & 0.00 & 0.00 & 0.00 & 0.00 & 0.00 & 0.03 \\
\hline 31 & 0.00 & --- & 0.00 & 0.01 & --- & 0.00 & --- & 0.00 & --- & 0.00 & 0.00 & --- \\
\hline TOTAL & 1.57 & 0.71 & 0.38 & 0.15 & 1.03 & 1.17 & 2.68 & 0.00 & 0.38 & 2.59 & 0.74 & 0.81 \\
\hline MAX & 0.55 & 0.54 & 0.14 & 0.07 & 0.49 & 0.70 & 1.36 & 0.00 & 0.38 & 0.96 & 0.25 & 0.44 \\
\hline MIN & 0.00 & 0.00 & 0.00 & 0.00 & 0.00 & 0.00 & 0.00 & 0.00 & 0.00 & 0.00 & 0.00 & 0.00 \\
\hline
\end{tabular}

CAL YR 2003 TOTAL 12.67 MAX 1.44 MIN 0.00

WTR YR 2004 TOTAL 12.21 MAX 1.36 MIN 0.00 


\section{0, FIRE STATION \#16 RAIN GAGE IN ALBUQUERQUE, NEW MEXICO STATION ANALYSIS \\ WATER YEAR 2004}

Location.--35 $05^{\prime} 09^{\prime} \mathrm{N}, 106^{\circ} 30^{\prime} 58^{\prime \prime} \mathrm{W}$. The rain gage is located in northeast Albuquerque, approximately 0.5 mile north of the intersection of Montgomery and Juan Tabo Boulevards.

Equipment.--Onset Corporation HOBO Event data recorder and 7.9-inch-diameter tipping bucket. The bucket tips one time per 0.01 inch of rain, and the recorder stores data at 5-minute intervals. Rain gage is calibrated approximately every 2 years and was last calibrated in March 2003.

Record.--The rain gage gave a complete and satisfactory record for the entire water year.

Period of Record.--June 1983 to present.

Remarks.--Record is good for the entire water year.

PRECIPITATION, TOTAL, INCHES, WATER YEAR OCTOBER 2003 TO SEPTEMBER 2004 DAILY SUM VALUES

\begin{tabular}{|c|c|c|c|c|c|c|c|c|c|c|c|c|}
\hline DAY & ОСт & NOV & $\mathrm{DEC}$ & JAN & FEB & MAR & APR & MAY & JUN & JUL & AUG & SEP \\
\hline 1 & 0.00 & 0.00 & 0.00 & 0.00 & 0.04 & 0.00 & 0.00 & 0.00 & 0.00 & 0.00 & 0.00 & 0.00 \\
\hline 2 & 0.00 & 0.00 & 0.00 & 0.00 & 0.02 & 0.13 & 0.35 & 0.00 & 0.00 & 0.00 & 0.13 & 0.00 \\
\hline 3 & 0.07 & 0.00 & 0.00 & 0.00 & 0.00 & 0.00 & 0.98 & 0.00 & 0.00 & 0.00 & 0.01 & 0.00 \\
\hline 4 & 0.03 & 0.00 & 0.00 & 0.00 & 0.11 & 0.84 & 0.31 & 0.00 & 0.00 & 0.00 & 0.55 & 0.12 \\
\hline 5 & 0.00 & 0.00 & 0.00 & 0.00 & 0.00 & 0.08 & 0.00 & 0.00 & 0.00 & 0.00 & 0.00 & 0.00 \\
\hline 6 & 0.00 & 0.00 & 0.00 & 0.00 & 0.00 & 0.00 & 0.00 & 0.00 & 0.00 & 0.00 & 0.00 & 0.00 \\
\hline 7 & 0.73 & 0.00 & 0.00 & 0.00 & 0.00 & 0.00 & 0.00 & 0.00 & 0.00 & 0.00 & 0.00 & 0.00 \\
\hline 8 & 0.19 & 0.00 & 0.00 & 0.00 & 0.00 & 0.00 & 0.34 & 0.00 & 0.00 & 0.00 & 0.00 & 0.00 \\
\hline 9 & 0.00 & 0.00 & 0.00 & 0.00 & 0.00 & 0.00 & 0.15 & 0.00 & 0.00 & 0.00 & 0.00 & 0.00 \\
\hline 10 & 0.18 & 0.00 & 0.00 & 0.00 & 0.00 & 0.00 & 0.24 & 0.00 & 0.00 & 0.00 & 0.00 & 0.00 \\
\hline 11 & 0.00 & 0.00 & 0.00 & 0.00 & 0.00 & 0.00 & 0.00 & 0.00 & 0.00 & 0.01 & 0.00 & 0.00 \\
\hline 12 & 0.00 & 0.77 & 0.15 & 0.00 & 0.00 & 0.00 & 0.00 & 0.00 & 0.00 & 0.12 & 0.02 & 0.00 \\
\hline 13 & 0.00 & 0.35 & 0.00 & 0.00 & 0.00 & 0.00 & 0.00 & 0.00 & 0.00 & 0.00 & 0.00 & 0.00 \\
\hline 14 & 0.00 & 0.00 & 0.00 & 0.00 & 0.00 & 0.00 & 0.00 & 0.00 & 0.00 & 0.03 & 0.00 & 0.00 \\
\hline 15 & 0.00 & 0.00 & 0.00 & 0.02 & 0.00 & 0.00 & 0.00 & 0.00 & 0.00 & 0.00 & 0.00 & 0.00 \\
\hline 16 & 0.00 & 0.04 & 0.00 & 0.00 & 0.00 & 0.00 & 0.00 & 0.00 & 0.00 & 0.00 & 0.00 & 0.00 \\
\hline 17 & 0.00 & 0.01 & 0.00 & 0.00 & 0.00 & 0.00 & 0.00 & 0.00 & 0.00 & 0.00 & 0.00 & 0.00 \\
\hline 18 & 0.00 & 0.00 & 0.00 & 0.00 & 0.00 & 0.00 & 0.00 & 0.00 & 0.00 & 0.00 & 0.00 & 0.06 \\
\hline 19 & 0.00 & 0.00 & 0.00 & 0.00 & 0.00 & 0.00 & 0.00 & 0.00 & 0.00 & 0.00 & 0.02 & 0.89 \\
\hline 20 & 0.00 & 0.00 & 0.00 & 0.10 & 0.00 & 0.00 & 0.00 & 0.00 & 0.00 & 0.14 & 0.00 & 0.10 \\
\hline 21 & 0.00 & 0.00 & 0.00 & 0.00 & 0.13 & 0.00 & 0.00 & 0.00 & 0.00 & 0.00 & 0.02 & 0.00 \\
\hline 22 & 0.00 & 0.00 & 0.00 & 0.00 & 0.00 & 0.00 & 0.00 & 0.00 & 0.00 & 0.21 & 0.00 & 0.00 \\
\hline 23 & 0.00 & 0.00 & 0.00 & 0.00 & 0.57 & 0.03 & 0.00 & 0.00 & 0.00 & 0.36 & 0.00 & 0.00 \\
\hline 24 & 0.00 & 0.00 & 0.00 & 0.00 & 0.25 & 0.00 & 0.00 & 0.00 & 0.00 & 0.15 & 0.00 & 0.00 \\
\hline 25 & 0.00 & 0.00 & 0.00 & 0.11 & 0.00 & 0.00 & 0.00 & 0.00 & 0.02 & 0.19 & 0.00 & 0.00 \\
\hline 26 & 0.00 & 0.00 & 0.00 & 0.00 & 0.00 & 0.00 & 0.00 & 0.00 & 0.25 & 0.00 & 0.00 & 0.00 \\
\hline 27 & 0.00 & 0.00 & 0.00 & 0.00 & 0.00 & 0.00 & 0.00 & 0.00 & 0.00 & 0.44 & 0.00 & 0.01 \\
\hline 28 & 0.00 & 0.00 & 0.00 & 0.00 & 0.22 & 0.00 & 0.00 & 0.00 & 0.03 & 0.00 & 0.00 & 0.00 \\
\hline 29 & 0.00 & 0.00 & 0.00 & 0.00 & 0.00 & 0.00 & 0.00 & 0.00 & 0.41 & 0.00 & 0.00 & 0.00 \\
\hline 30 & 0.00 & 0.00 & 0.00 & 0.00 & --- & 0.00 & 0.00 & 0.00 & 0.00 & 0.00 & 0.00 & 0.00 \\
\hline 31 & 0.00 & --- & 0.00 & 0.00 & --- & 0.00 & --- & 0.00 & --- & 0.00 & 0.00 & --- \\
\hline TOTAL & 1.20 & 1.17 & 0.15 & 0.23 & 1.34 & 1.08 & 2.37 & 0.00 & 0.71 & 1.65 & 0.75 & 1.18 \\
\hline MAX & 0.73 & 0.77 & 0.15 & 0.11 & 0.57 & 0.84 & 0.98 & 0.00 & 0.41 & 0.44 & 0.55 & 0.89 \\
\hline MIN & 0.00 & 0.00 & 0.00 & 0.00 & 0.00 & 0.00 & 0.00 & 0.00 & 0.00 & 0.00 & 0.00 & 0.00 \\
\hline
\end{tabular}




\section{0, HAHN ARROYO RAIN GAGE IN ALBUQUERQUE, NEW MEXICO STATION ANALYSIS \\ WATER YEAR 2004}

Location.--35 $07^{\prime} 33^{\prime \prime} \mathrm{N}, 106^{\circ} 35^{\prime} 23^{\prime}$ W. The rain gage is located in northeast Albuquerque at the surface-water gage, east of Monroe Street between Comanche Road and Montgomery Boulevard.

Equipment.--8.2-inch-diameter tipping bucket connected to a surface-water data recorder. The bucket tips one time per 0.01 inch of rain, and the recorder stores data at 5-minute intervals. Rain gage is calibrated approximately every 2 years and was last calibrated in March 2003.

Record.-- The rain gage gave a complete and satisfactory record for the entire water year.

Period of Record.--March 1984 to present.

Remarks.--Record is good for the entire water year.

PRECIPITATION, TOTAL, INCHES, WATER YEAR OCTOBER 2003 TO SEPTEMBER 2004 DAILY SUM VALUES

\begin{tabular}{|c|c|c|c|c|c|c|c|c|c|c|c|c|}
\hline DAY & OCT & NOV & DEC & JAN & FEB & MAR & APR & MAY & JUN & JUL & AUG & SEP \\
\hline 1 & 0.00 & 0.00 & 0.00 & 0.00 & 0.04 & 0.00 & 0.00 & 0.00 & 0.00 & 0.00 & 0.00 & 0.00 \\
\hline 2 & 0.00 & 0.00 & 0.00 & 0.00 & 0.00 & 0.09 & 0.25 & 0.00 & 0.00 & 0.00 & 0.14 & 0.00 \\
\hline 3 & 0.09 & 0.00 & 0.00 & 0.00 & 0.04 & 0.01 & 0.98 & 0.00 & 0.00 & 0.00 & 0.00 & 0.00 \\
\hline 4 & 0.03 & 0.00 & 0.00 & 0.00 & 0.01 & 0.68 & 0.09 & 0.00 & 0.00 & 0.00 & 0.28 & 0.05 \\
\hline 5 & 0.00 & 0.00 & 0.00 & 0.00 & 0.00 & 0.06 & 0.00 & 0.00 & 0.00 & 0.00 & 0.00 & 0.00 \\
\hline 6 & 0.00 & 0.00 & 0.00 & 0.00 & 0.00 & 0.00 & 0.00 & 0.00 & 0.00 & 0.00 & 0.00 & 0.00 \\
\hline 7 & 0.74 & 0.00 & 0.00 & 0.00 & 0.00 & 0.00 & 0.00 & 0.00 & 0.00 & 0.00 & 0.00 & 0.00 \\
\hline 8 & 0.24 & 0.00 & 0.02 & 0.00 & 0.00 & 0.00 & 0.25 & 0.00 & 0.00 & 0.00 & 0.00 & 0.00 \\
\hline 9 & 0.00 & 0.00 & 0.00 & 0.00 & 0.00 & 0.00 & 0.04 & 0.00 & 0.00 & 0.00 & 0.00 & 0.00 \\
\hline 10 & 0.21 & 0.00 & 0.00 & 0.00 & 0.00 & 0.00 & 0.24 & 0.00 & 0.00 & 0.00 & 0.41 & 0.00 \\
\hline 11 & 0.01 & 0.00 & 0.00 & 0.00 & 0.00 & 0.00 & 0.00 & 0.00 & 0.00 & 0.18 & 0.00 & 0.00 \\
\hline 12 & 0.00 & 0.62 & 0.12 & 0.00 & 0.00 & 0.00 & 0.00 & 0.00 & 0.00 & 0.70 & 0.00 & 0.00 \\
\hline 13 & 0.00 & 0.25 & 0.00 & 0.00 & 0.00 & 0.00 & 0.00 & 0.00 & 0.00 & 0.00 & 0.00 & 0.00 \\
\hline 14 & 0.00 & 0.00 & 0.00 & 0.00 & 0.00 & 0.00 & 0.00 & 0.00 & 0.00 & 0.00 & 0.00 & 0.00 \\
\hline 15 & 0.00 & 0.00 & 0.00 & 0.02 & 0.00 & 0.00 & 0.00 & 0.00 & 0.00 & 0.09 & 0.00 & 0.00 \\
\hline 16 & 0.00 & 0.00 & 0.00 & 0.02 & 0.00 & 0.00 & 0.00 & 0.00 & 0.00 & 0.00 & 0.00 & 0.00 \\
\hline 17 & 0.00 & 0.00 & 0.00 & 0.00 & 0.00 & 0.00 & 0.01 & 0.00 & 0.00 & 0.00 & 0.00 & 0.00 \\
\hline 18 & 0.00 & 0.00 & 0.00 & 0.00 & 0.00 & 0.00 & 0.00 & 0.00 & 0.00 & 0.00 & 0.00 & 0.06 \\
\hline 19 & 0.00 & 0.00 & 0.00 & 0.00 & 0.00 & 0.00 & 0.00 & 0.00 & 0.00 & 0.00 & 0.11 & 0.85 \\
\hline 20 & 0.00 & 0.00 & 0.00 & 0.07 & 0.00 & 0.00 & 0.00 & 0.00 & 0.00 & 0.05 & 0.00 & 0.03 \\
\hline 21 & 0.00 & 0.00 & 0.00 & 0.00 & 0.03 & 0.00 & 0.00 & 0.00 & 0.00 & 0.00 & 0.00 & 0.00 \\
\hline 22 & 0.00 & 0.00 & 0.00 & 0.00 & 0.00 & 0.00 & 0.00 & 0.00 & 0.00 & 0.00 & 0.00 & 0.00 \\
\hline 23 & 0.00 & 0.00 & 0.00 & 0.00 & 0.86 & 0.03 & 0.00 & 0.00 & 0.00 & 0.87 & 0.00 & 0.00 \\
\hline 24 & 0.00 & 0.00 & 0.00 & 0.00 & 0.35 & 0.00 & 0.00 & 0.00 & 0.00 & 0.12 & 0.00 & 0.00 \\
\hline 25 & 0.00 & 0.00 & 0.00 & 0.03 & 0.00 & 0.00 & 0.00 & 0.00 & 0.00 & 0.30 & 0.00 & 0.00 \\
\hline 26 & 0.00 & 0.00 & 0.00 & 0.00 & 0.00 & 0.00 & 0.00 & 0.00 & 0.25 & 0.00 & 0.00 & 0.00 \\
\hline 27 & 0.00 & 0.00 & 0.00 & 0.00 & 0.00 & 0.00 & 0.00 & 0.00 & 0.00 & 0.77 & 0.00 & 0.00 \\
\hline 28 & 0.00 & 0.00 & 0.00 & 0.00 & 0.14 & 0.00 & 0.00 & 0.00 & 0.00 & 0.05 & 0.00 & 0.00 \\
\hline 29 & 0.00 & 0.00 & 0.00 & 0.00 & 0.00 & 0.00 & 0.00 & 0.00 & 0.41 & 0.00 & 0.00 & 0.19 \\
\hline 30 & 0.00 & 0.00 & 0.00 & 0.00 & --- & 0.00 & 0.00 & 0.00 & 0.00 & 0.00 & 0.00 & 0.00 \\
\hline 31 & 0.00 & --- & 0.00 & 0.00 & --- & 0.00 & --- & 0.00 & --- & 0.00 & 0.00 & --- \\
\hline TOTAL & 1.32 & 0.87 & 0.14 & 0.14 & 1.47 & 0.87 & 1.86 & 0.00 & 0.66 & 3.13 & 0.94 & 1.18 \\
\hline MAX & 0.74 & 0.62 & 0.12 & 0.07 & 0.86 & 0.68 & 0.98 & 0.00 & 0.41 & 0.87 & 0.41 & 0.85 \\
\hline MIN & 0.00 & 0.00 & 0.00 & 0.00 & 0.00 & 0.00 & 0.00 & 0.00 & 0.00 & 0.00 & 0.00 & 0.00 \\
\hline
\end{tabular}




\section{0, KIRTLAND AIR FORCE BASE RAIN GAGE AT EUBANK GATE, ALBUQUERQUE, NEW MEXICO \\ STATION ANALYSIS \\ WATER YEAR 2004}

Location.--35 $03^{\prime} 10^{\prime \prime} \mathrm{N}, 106^{\circ} 32^{\prime} 09^{\prime \prime} \mathrm{W}$. The rain gage is located in southeast Albuquerque on Kirtland Air Force Base, near the southern terminus of Eubank Boulevard.

Equipment.-- Onset Corporation HOBO Event data recorder and 6.5-inch-diameter tipping bucket. The bucket tips one time per 0.01 inch of rain, and the recorder stores data at 5-minute intervals. Rain gage is calibrated approximately every 2 years and was last calibrated in March 2003.

Record.--The rain gage gave a complete and satisfactory record for the water year except for November 13 to December 3. During this period the data recorder malfunctioned. Estimated daily totals for these days are averages of daily totals from the Orlando Romero, Love Pump, and Tramway rain gages.

Period of Record.--June 2001 to present.

Remarks.--Record is good for the entire water year including days estimated as zero; other estimates are poor.

PRECIPITATION, TOTAL, INCHES, WATER YEAR OCTOBER 2003 TO SEPTEMBER 2004 DAILY SUM VALUES

\begin{tabular}{|c|c|c|c|c|c|c|c|c|c|c|c|c|}
\hline DAY & ОСт & Nov & DEC & JAN & FEB & MAR & APR & MAY & JUN & JUL & AUG & SEP \\
\hline 1 & 0.00 & 0.00 & $\mathrm{e} 0.00$ & 0.00 & 0.02 & 0.00 & 0.00 & 0.00 & 0.00 & 0.00 & 0.00 & 0.00 \\
\hline 2 & 0.00 & 0.00 & $\mathrm{e} 0.00$ & 0.00 & 0.00 & 0.09 & 0.17 & 0.00 & 0.00 & 0.00 & 0.28 & 0.00 \\
\hline 3 & 0.09 & 0.00 & $\mathrm{e} 0.00$ & 0.00 & 0.01 & 0.00 & 0.98 & 0.00 & 0.00 & 0.00 & 0.00 & 0.00 \\
\hline 4 & 0.02 & 0.00 & 0.00 & 0.00 & 0.03 & 0.71 & 0.41 & 0.00 & 0.06 & 0.00 & 1.44 & 0.13 \\
\hline 5 & 0.00 & 0.00 & 0.00 & 0.00 & 0.00 & 0.10 & 0.00 & 0.00 & 0.00 & 0.00 & 0.00 & 0.01 \\
\hline 6 & 0.00 & 0.00 & 0.00 & 0.00 & 0.00 & 0.00 & 0.00 & 0.00 & 0.00 & 0.00 & 0.00 & 0.00 \\
\hline 7 & 0.90 & 0.00 & 0.00 & 0.00 & 0.00 & 0.00 & 0.00 & 0.00 & 0.00 & 0.00 & 0.00 & 0.00 \\
\hline 8 & 0.16 & 0.00 & 0.03 & 0.00 & 0.00 & 0.00 & 0.33 & 0.00 & 0.00 & 0.00 & 0.00 & 0.00 \\
\hline 9 & 0.00 & 0.00 & 0.00 & 0.00 & 0.00 & 0.00 & 0.00 & 0.00 & 0.00 & 0.00 & 0.00 & 0.00 \\
\hline 10 & 0.04 & 0.00 & 0.00 & 0.00 & 0.00 & 0.00 & 0.16 & 0.00 & 0.00 & 0.02 & 0.18 & 0.00 \\
\hline 11 & 0.00 & 0.02 & 0.00 & 0.00 & 0.00 & 0.00 & 0.01 & 0.00 & 0.00 & 0.00 & 0.00 & 0.00 \\
\hline 12 & 0.00 & 0.44 & 0.18 & 0.00 & 0.00 & 0.01 & 0.00 & 0.00 & 0.00 & 0.00 & 0.00 & 0.00 \\
\hline 13 & 0.00 & e 0.28 & 0.01 & 0.00 & 0.00 & 0.00 & 0.00 & 0.00 & 0.00 & 0.00 & 0.00 & 0.00 \\
\hline 14 & 0.00 & e0.00 & 0.00 & 0.00 & 0.00 & 0.00 & 0.00 & 0.00 & 0.00 & 0.00 & 0.00 & 0.00 \\
\hline 15 & 0.00 & e0.00 & 0.00 & 0.03 & 0.00 & 0.00 & 0.00 & 0.00 & 0.00 & 0.11 & 0.00 & 0.00 \\
\hline 16 & 0.00 & e0.03 & 0.00 & 0.01 & 0.00 & 0.00 & 0.00 & 0.00 & 0.00 & 0.00 & 0.00 & 0.00 \\
\hline 17 & 0.00 & e0.01 & 0.00 & 0.02 & 0.00 & 0.00 & 0.00 & 0.00 & 0.00 & 0.00 & 0.00 & 0.00 \\
\hline 18 & 0.00 & e0.00 & 0.00 & 0.00 & 0.00 & 0.00 & 0.00 & 0.00 & 0.00 & 0.01 & 0.01 & 0.07 \\
\hline 19 & 0.00 & e0.00 & 0.00 & 0.00 & 0.00 & 0.00 & 0.00 & 0.00 & 0.00 & 0.00 & 0.02 & 0.48 \\
\hline 20 & 0.00 & e0.00 & 0.00 & 0.12 & 0.00 & 0.00 & 0.00 & 0.00 & 0.00 & 0.15 & 0.00 & 0.10 \\
\hline 21 & 0.00 & $\mathrm{e} 0.00$ & 0.00 & 0.01 & 0.06 & 0.00 & 0.00 & 0.00 & 0.00 & 0.04 & 0.00 & 0.00 \\
\hline 22 & 0.00 & e0.00 & 0.00 & 0.00 & 0.00 & 0.00 & 0.00 & 0.00 & 0.00 & 0.39 & 0.00 & 0.00 \\
\hline 23 & 0.00 & $\mathrm{e} 0.00$ & 0.00 & 0.00 & 0.82 & 0.04 & 0.00 & 0.00 & 0.00 & 1.04 & 0.00 & 0.00 \\
\hline 24 & 0.00 & $\mathrm{e} 0.00$ & 0.00 & 0.00 & 0.35 & 0.00 & 0.00 & 0.00 & 0.00 & 0.11 & 0.00 & 0.00 \\
\hline 25 & 0.00 & $\mathrm{e} 0.00$ & 0.00 & 0.03 & 0.00 & 0.00 & 0.00 & 0.00 & 0.00 & 0.25 & 0.00 & 0.00 \\
\hline 26 & 0.00 & e0.00 & 0.00 & 0.00 & 0.00 & 0.00 & 0.00 & 0.00 & 0.00 & 0.00 & 0.00 & 0.00 \\
\hline 27 & 0.00 & $\mathrm{e} 0.00$ & 0.00 & 0.00 & 0.00 & 0.00 & 0.00 & 0.00 & 0.00 & 0.30 & 0.00 & 0.01 \\
\hline 28 & 0.00 & $\mathrm{e} 0.00$ & 0.00 & 0.00 & 0.13 & 0.00 & 0.00 & 0.00 & 0.98 & 0.04 & 0.00 & 0.00 \\
\hline 29 & 0.00 & e0.00 & 0.00 & 0.00 & 0.00 & 0.00 & 0.00 & 0.00 & 0.53 & 0.00 & 0.00 & 0.00 \\
\hline 30 & 0.00 & e0.00 & 0.00 & 0.00 & --- & 0.00 & 0.00 & 0.00 & 0.00 & 0.00 & 0.00 & 0.00 \\
\hline 31 & 0.00 & --- & 0.00 & 0.00 & --- & 0.00 & --- & 0.00 & --- & 0.00 & 0.00 & --- \\
\hline TOTAL & 1.21 & 0.78 & 0.22 & 0.22 & 1.42 & 0.95 & 2.06 & 0.00 & 1.57 & 2.46 & 1.93 & 0.80 \\
\hline MAX & 0.90 & 0.44 & 0.18 & 0.12 & 0.82 & 0.71 & 0.98 & 0.00 & 0.98 & 1.04 & 1.44 & 0.48 \\
\hline MIN & 0.00 & 0.00 & 0.00 & 0.00 & 0.00 & 0.00 & 0.00 & 0.00 & 0.00 & 0.00 & 0.00 & 0.00 \\
\hline
\end{tabular}

CAL YR 2003 TOTAL 7.06 MAX 0.90 MIN 0.00

WTR YR 2004 TOTAL 13.62 MAX 1.44 MIN 0.00 


\section{0, LA BOCA NEGRA RAIN GAGE NEAR ALBUQUERQUE, NEW MEXICO STATION ANALYSIS \\ WATER YEAR 2004}

Location.-- $35^{\circ} 09^{\prime} 18^{\prime \prime} \mathrm{N}, 106^{\circ} 45^{\prime} 58^{\prime \prime} \mathrm{W}$. The rain gage is located in far northwest Albuquerque, approximately 0.25 mile north of the West Mesa volcanoes.

Equipment.--Onset Corporation HOBO Event data recorder and 8.2-inch-diameter tipping bucket. The bucket tips one time per 0.01 inch of rain, and the recorder stores data at 5 -minute intervals. Rain gage is calibrated approximately every 2 years and was last calibrated in March 2003.

Record.--The rain gage gave a complete and satisfactory record for the entire water year.

Period of Record.--October 1990 to present.

Remarks.--Record is good for the entire water year.

PRECIPITATION, TOTAL, INCHES, WATER YEAR OCTOBER 2003 TO SEPTEMBER 2004 DAILY SUM VALUES

\begin{tabular}{|c|c|c|c|c|c|c|c|c|c|c|c|c|}
\hline DAY & ОСт & NOV & $\mathrm{DEC}$ & JAN & FEB & MAR & APR & MAY & JUN & JUL & AUG & SEP \\
\hline 1 & 0.00 & 0.00 & 0.00 & 0.00 & 0.00 & 0.00 & 0.00 & 0.00 & 0.00 & 0.00 & 0.00 & 0.00 \\
\hline 2 & 0.00 & 0.00 & 0.00 & 0.00 & 0.00 & 0.39 & 0.74 & 0.00 & 0.00 & 0.00 & 0.04 & 0.00 \\
\hline 3 & 0.12 & 0.00 & 0.00 & 0.00 & 0.00 & 0.05 & 2.14 & 0.00 & 0.00 & 0.00 & 0.01 & 0.08 \\
\hline 4 & 0.04 & 0.00 & 0.00 & 0.00 & 0.00 & 0.69 & 0.27 & 0.00 & 0.00 & 0.00 & 0.00 & 0.07 \\
\hline 5 & 0.00 & 0.00 & 0.00 & 0.00 & 0.00 & 0.02 & 0.00 & 0.00 & 0.00 & 0.00 & 0.15 & 0.00 \\
\hline 6 & 0.00 & 0.00 & 0.00 & 0.00 & 0.00 & 0.00 & 0.00 & 0.00 & 0.00 & 0.00 & 0.00 & 0.00 \\
\hline 7 & 0.87 & 0.00 & 0.00 & 0.00 & 0.00 & 0.00 & 0.01 & 0.00 & 0.00 & 0.00 & 0.00 & 0.00 \\
\hline 8 & 0.27 & 0.00 & 0.03 & 0.00 & 0.00 & 0.00 & 0.30 & 0.00 & 0.00 & 0.00 & 0.00 & 0.00 \\
\hline 9 & 0.00 & 0.00 & 0.00 & 0.00 & 0.00 & 0.00 & 0.02 & 0.00 & 0.00 & 0.00 & 0.00 & 0.00 \\
\hline 10 & 0.00 & 0.01 & 0.00 & 0.00 & 0.00 & 0.00 & 0.87 & 0.00 & 0.00 & 0.00 & 0.00 & 0.00 \\
\hline 11 & 0.00 & 0.00 & 0.00 & 0.00 & 0.00 & 0.00 & 0.00 & 0.00 & 0.00 & 0.00 & 0.00 & 0.00 \\
\hline 12 & 0.00 & 0.76 & 0.08 & 0.00 & 0.00 & 0.00 & 0.00 & 0.00 & 0.00 & 0.01 & 0.00 & 0.00 \\
\hline 13 & 0.00 & 0.18 & 0.00 & 0.00 & 0.00 & 0.00 & 0.00 & 0.00 & 0.00 & 0.00 & 0.01 & 0.00 \\
\hline 14 & 0.00 & 0.00 & 0.00 & 0.00 & 0.00 & 0.00 & 0.00 & 0.00 & 0.00 & 0.00 & 0.01 & 0.00 \\
\hline 15 & 0.00 & 0.01 & 0.00 & 0.05 & 0.00 & 0.00 & 0.00 & 0.00 & 0.00 & 0.00 & 0.00 & 0.00 \\
\hline 16 & 0.00 & 0.00 & 0.00 & 0.03 & 0.00 & 0.00 & 0.00 & 0.00 & 0.00 & 0.00 & 0.00 & 0.00 \\
\hline 17 & 0.00 & 0.00 & 0.00 & 0.00 & 0.00 & 0.00 & 0.00 & 0.00 & 0.00 & 0.00 & 0.00 & 0.00 \\
\hline 18 & 0.00 & 0.00 & 0.00 & 0.00 & 0.00 & 0.00 & 0.00 & 0.00 & 0.00 & 0.01 & 0.00 & 0.10 \\
\hline 19 & 0.00 & 0.00 & 0.00 & 0.00 & 0.00 & 0.00 & 0.00 & 0.00 & 0.00 & 0.07 & 0.00 & 0.34 \\
\hline 20 & 0.00 & 0.00 & 0.00 & 0.12 & 0.00 & 0.00 & 0.00 & 0.00 & 0.00 & 0.04 & 0.00 & 0.00 \\
\hline 21 & 0.00 & 0.00 & 0.00 & 0.01 & 0.07 & 0.00 & 0.00 & 0.00 & 0.00 & 0.01 & 0.00 & 0.00 \\
\hline 22 & 0.00 & 0.00 & 0.00 & 0.00 & 0.01 & 0.00 & 0.00 & 0.00 & 0.00 & 0.46 & 0.00 & 0.00 \\
\hline 23 & 0.00 & 0.00 & 0.00 & 0.00 & 0.43 & 0.00 & 0.01 & 0.00 & 0.00 & 0.04 & 0.00 & 0.00 \\
\hline 24 & 0.00 & 0.00 & 0.00 & 0.00 & 0.63 & 0.00 & 0.00 & 0.00 & 0.00 & 0.80 & 0.00 & 0.00 \\
\hline 25 & 0.00 & 0.00 & 0.00 & 0.05 & 0.05 & 0.00 & 0.00 & 0.00 & 0.00 & 0.17 & 0.00 & 0.00 \\
\hline 26 & 0.00 & 0.00 & 0.00 & 0.00 & 0.00 & 0.00 & 0.00 & 0.00 & 0.02 & 0.00 & 0.00 & 0.00 \\
\hline 27 & 0.00 & 0.00 & 0.00 & 0.00 & 0.00 & 0.00 & 0.00 & 0.00 & 0.00 & 0.11 & 0.00 & 0.00 \\
\hline 28 & 0.00 & 0.00 & 0.00 & 0.00 & 0.15 & 0.00 & 0.00 & 0.00 & 0.00 & 0.00 & 0.00 & 0.00 \\
\hline 29 & 0.00 & 0.00 & 0.00 & 0.00 & 0.00 & 0.00 & 0.00 & 0.00 & 0.49 & 0.00 & 0.00 & 0.56 \\
\hline 30 & 0.00 & 0.00 & 0.00 & 0.00 & --- & 0.00 & 0.00 & 0.00 & 0.00 & 0.00 & 0.00 & 0.00 \\
\hline 31 & 0.00 & --- & 0.00 & 0.00 & --- & 0.00 & --- & 0.00 & --- & 0.00 & 0.00 & --- \\
\hline TOTAL & 1.30 & 0.96 & 0.11 & 0.26 & 1.34 & 1.15 & 4.36 & 0.00 & 0.51 & 1.72 & 0.22 & 1.15 \\
\hline MAX & 0.87 & 0.76 & 0.08 & 0.12 & 0.63 & 0.69 & 2.14 & 0.00 & 0.49 & 0.80 & 0.15 & 0.56 \\
\hline MIN & 0.00 & 0.00 & 0.00 & 0.00 & 0.00 & 0.00 & 0.00 & 0.00 & 0.00 & 0.00 & 0.00 & 0.00 \\
\hline
\end{tabular}

CAL YR 2003 TOTAL 6.89 MAX 0.87 MIN 0.00

WTR YR 2004 TOTAL 13.08 MAX 2.14 MIN 0.00 


\section{0, LA CUEVA ARROYO TRIBUTARY RAIN GAGE NEAR ALBUQUERQUE, NEW MEXICO STATION ANALYSIS \\ WATER YEAR 2004}

Location.--35 $11^{\prime} 31^{\prime \prime} \mathrm{N}, 106^{\circ} 29^{\prime} 46^{\prime} \mathrm{W}$. The rain gage is located in northeast Albuquerque, approximately 0.25 mile north of the surface-water gage and just north of the intersection of Tramway Road and Tramway Boulevard.

Equipment.--Onset Corporation HOBO Event data recorder and 8.2-inch-diameter tipping bucket. The bucket tips one time per 0.01 inch of rain, and the recorder stores data at 5-minute intervals. Rain gage is calibrated approximately every 2 years and was last calibrated in March 2003.

Record.--The rain gage gave a complete and satisfactory record for the water year.

Period of Record.--July 1981 to present.

Remarks.--Record is good for the entire water year.

PRECIPITATION, TOTAL, INCHES, WATER YEAR OCTOBER 2003 TO SEPTEMBER 2004 DAILY SUM VALUES

\begin{tabular}{|c|c|c|c|c|c|c|c|c|c|c|c|c|}
\hline DAY & Ост & NOV & DEC & JAN & FEB & MAR & APR & MAY & JUN & JUL & AUG & SEP \\
\hline 1 & 0.00 & 0.00 & 0.00 & 0.00 & 0.03 & 0.00 & 0.00 & 0.00 & 0.00 & 0.00 & 0.00 & 0.00 \\
\hline 2 & 0.00 & 0.00 & 0.00 & 0.00 & 0.00 & 0.24 & 0.86 & 0.00 & 0.00 & 0.00 & 0.06 & 0.00 \\
\hline 3 & 0.18 & 0.00 & 0.00 & 0.00 & 0.00 & 0.00 & 2.56 & 0.00 & 0.00 & 0.00 & 0.01 & 0.00 \\
\hline 4 & 0.14 & 0.00 & 0.00 & 0.00 & 0.04 & 1.72 & 1.04 & 0.00 & 0.00 & 0.00 & 0.13 & 0.03 \\
\hline 5 & 0.00 & 0.00 & 0.00 & 0.00 & 0.00 & 0.14 & 0.00 & 0.00 & 0.00 & 0.00 & 0.00 & 0.00 \\
\hline 6 & 0.00 & 0.00 & 0.00 & 0.00 & 0.00 & 0.00 & 0.00 & 0.00 & 0.00 & 0.00 & 0.17 & 0.00 \\
\hline 7 & 1.29 & 0.00 & 0.00 & 0.00 & 0.00 & 0.00 & 0.00 & 0.00 & 0.00 & 0.00 & 0.00 & 0.00 \\
\hline 8 & 0.50 & 0.00 & 0.07 & 0.00 & 0.00 & 0.00 & 0.71 & 0.00 & 0.00 & 0.00 & 0.00 & 0.00 \\
\hline 9 & 0.00 & 0.00 & 0.00 & 0.00 & 0.00 & 0.00 & 0.15 & 0.00 & 0.00 & 0.00 & 0.00 & 0.00 \\
\hline 10 & 0.27 & 0.01 & 0.00 & 0.00 & 0.00 & 0.00 & 0.46 & 0.00 & 0.00 & 0.00 & 0.00 & 0.00 \\
\hline 11 & 0.01 & 0.00 & 0.00 & 0.00 & 0.00 & 0.00 & 0.01 & 0.00 & 0.00 & 0.00 & 0.00 & 0.00 \\
\hline 12 & 0.00 & 1.45 & 0.44 & 0.00 & 0.00 & 0.00 & 0.00 & 0.00 & 0.00 & 0.02 & 0.00 & 0.00 \\
\hline 13 & 0.00 & 0.65 & 0.00 & 0.00 & 0.00 & 0.00 & 0.00 & 0.00 & 0.00 & 0.00 & 0.00 & 0.00 \\
\hline 14 & 0.00 & 0.00 & 0.00 & 0.00 & 0.00 & 0.00 & 0.00 & 0.00 & 0.00 & 0.00 & 0.46 & 0.00 \\
\hline 15 & 0.00 & 0.04 & 0.00 & 0.08 & 0.00 & 0.00 & 0.00 & 0.00 & 0.00 & 0.00 & 0.00 & 0.00 \\
\hline 16 & 0.00 & 0.01 & 0.00 & 0.02 & 0.00 & 0.00 & 0.00 & 0.00 & 0.00 & 0.00 & 0.00 & 0.00 \\
\hline 17 & 0.00 & 0.08 & 0.00 & 0.00 & 0.00 & 0.00 & 0.00 & 0.00 & 0.00 & 0.00 & 0.00 & 0.00 \\
\hline 18 & 0.00 & 0.00 & 0.00 & 0.00 & 0.00 & 0.00 & 0.00 & 0.00 & 0.00 & 0.00 & 0.00 & 0.02 \\
\hline 19 & 0.00 & 0.00 & 0.00 & 0.00 & 0.00 & 0.00 & 0.00 & 0.00 & 0.00 & 0.00 & 0.01 & 0.72 \\
\hline 20 & 0.00 & 0.00 & 0.00 & 0.33 & 0.00 & 0.00 & 0.00 & 0.00 & 0.00 & 0.13 & 0.00 & 0.15 \\
\hline 21 & 0.00 & 0.00 & 0.00 & 0.00 & 0.23 & 0.00 & 0.00 & 0.00 & 0.00 & 0.00 & 0.01 & 0.00 \\
\hline 22 & 0.00 & 0.00 & 0.01 & 0.01 & 0.00 & 0.00 & 0.00 & 0.00 & 0.00 & 0.01 & 0.00 & 0.00 \\
\hline 23 & 0.00 & 0.00 & 0.00 & 0.00 & 0.61 & 0.02 & 0.01 & 0.00 & 0.00 & 0.20 & 0.00 & 0.00 \\
\hline 24 & 0.00 & 0.00 & 0.00 & 0.00 & 0.45 & 0.00 & 0.00 & 0.00 & 0.00 & 0.34 & 0.00 & 0.00 \\
\hline 25 & 0.00 & 0.00 & 0.00 & 0.04 & 0.41 & 0.00 & 0.00 & 0.00 & 0.00 & 0.05 & 0.00 & 0.00 \\
\hline 26 & 0.00 & 0.00 & 0.01 & 0.00 & 0.00 & 0.00 & 0.00 & 0.00 & 0.05 & 0.00 & 0.00 & 0.03 \\
\hline 27 & 0.00 & 0.00 & 0.00 & 0.00 & 0.00 & 0.00 & 0.00 & 0.00 & 0.00 & 0.25 & 0.00 & 0.01 \\
\hline 28 & 0.00 & 0.00 & 0.00 & 0.00 & 0.21 & 0.00 & 0.00 & 0.00 & 0.00 & 0.04 & 0.00 & 0.00 \\
\hline 29 & 0.00 & 0.00 & 0.00 & 0.00 & 0.05 & 0.00 & 0.00 & 0.00 & 0.40 & 0.00 & 0.00 & 0.01 \\
\hline 30 & 0.00 & 0.00 & 0.00 & 0.00 & --- & 0.00 & 0.00 & 0.00 & 0.01 & 0.00 & 0.00 & 0.00 \\
\hline 31 & 0.00 & --- & 0.00 & 0.00 & --- & 0.00 & --- & 0.00 & --- & 0.00 & 0.00 & --- \\
\hline TOTAL & 2.39 & 2.24 & 0.53 & 0.48 & 2.03 & 2.12 & 5.80 & 0.00 & 0.46 & 1.04 & 0.85 & 0.97 \\
\hline MAX & 1.29 & 1.45 & 0.44 & 0.33 & 0.61 & 1.72 & 2.56 & 0.00 & 0.40 & 0.34 & 0.46 & 0.72 \\
\hline MIN & 0.00 & 0.00 & 0.00 & 0.00 & 0.00 & 0.00 & 0.00 & 0.00 & 0.00 & 0.00 & 0.00 & 0.00 \\
\hline
\end{tabular}

CAL YR 2003 TOTAL 12.96 MAX 1.56 MIN 0.00

WTR YR 2004 TOTAL 18.91 MAX 2.56 MIN 0.00 


\section{8, LADERA ARROYO RAIN GAGE AT ALBUQUERQUE, NEW MEXICO STATION ANALYSIS \\ WATER YEAR 2004}

Location.--35 $06^{\prime} 56^{\prime \prime} \mathrm{N}, 106^{\circ} 44^{\prime} 48^{\prime \prime} \mathrm{W}$. The rain gage is located in far northwest Albuquerque in Petroglyphs National Park.

Equipment.--Onset Corporation HOBO Event data recorder and 8.2-inch-diameter tipping bucket. The bucket tips one time per 0.01 inch of rain, and the recorder stores data at 5 -minute intervals. Rain gage is calibrated approximately every 2 years and was last calibrated in March 2003.

Record.--The rain gage gave a complete and satisfactory record for the entire water year.

Period of Record.--May 1987 to present.

Remarks.--Record is good for the entire water year.

PRECIPITATION, TOTAL, INCHES, WATER YEAR OCTOBER 2003 TO SEPTEMBER 2004 DAILY SUM VALUES

\begin{tabular}{|c|c|c|c|c|c|c|c|c|c|c|c|c|}
\hline DAY & ОСт & NOV & DEC & JAN & FEB & MAR & APR & MAY & JUN & JUL & AUG & SEP \\
\hline 1 & 0.00 & 0.00 & 0.00 & 0.00 & 0.00 & 0.00 & 0.00 & 0.00 & 0.00 & 0.00 & 0.00 & 0.00 \\
\hline 2 & 0.00 & 0.00 & 0.00 & 0.00 & 0.00 & 0.38 & 0.80 & 0.00 & 0.00 & 0.00 & 0.04 & 0.00 \\
\hline 3 & 0.00 & 0.00 & 0.00 & 0.00 & 0.03 & 0.01 & 1.86 & 0.00 & 0.00 & 0.00 & 0.01 & 0.00 \\
\hline 4 & 0.00 & 0.00 & 0.00 & 0.00 & 0.00 & 1.21 & 0.16 & 0.00 & 0.00 & 0.00 & 0.01 & 0.09 \\
\hline 5 & 0.00 & 0.00 & 0.00 & 0.00 & 0.00 & 0.00 & 0.00 & 0.00 & 0.00 & 0.00 & 0.07 & 0.00 \\
\hline 6 & 0.00 & 0.00 & 0.00 & 0.00 & 0.00 & 0.00 & 0.00 & 0.00 & 0.00 & 0.00 & 0.00 & 0.00 \\
\hline 7 & 0.78 & 0.00 & 0.00 & 0.00 & 0.00 & 0.00 & 0.00 & 0.00 & 0.00 & 0.00 & 0.00 & 0.00 \\
\hline 8 & 0.24 & 0.00 & 0.05 & 0.00 & 0.00 & 0.00 & 0.28 & 0.00 & 0.00 & 0.00 & 0.00 & 0.00 \\
\hline 9 & 0.00 & 0.00 & 0.00 & 0.00 & 0.00 & 0.00 & 0.00 & 0.00 & 0.00 & 0.00 & 0.00 & 0.00 \\
\hline 10 & 0.01 & 0.00 & 0.00 & 0.00 & 0.00 & 0.00 & 0.47 & 0.00 & 0.00 & 0.00 & 0.00 & 0.00 \\
\hline 11 & 0.00 & 0.00 & 0.00 & 0.00 & 0.00 & 0.00 & 0.00 & 0.00 & 0.00 & 0.00 & 0.00 & 0.00 \\
\hline 12 & 0.00 & 0.63 & 0.22 & 0.00 & 0.00 & 0.00 & 0.00 & 0.03 & 0.00 & 0.00 & 0.00 & 0.00 \\
\hline 13 & 0.00 & 0.19 & 0.00 & 0.00 & 0.00 & 0.00 & 0.00 & 0.00 & 0.00 & 0.00 & 0.04 & 0.00 \\
\hline 14 & 0.00 & 0.00 & 0.00 & 0.00 & 0.00 & 0.00 & 0.00 & 0.00 & 0.00 & 0.00 & 0.00 & 0.00 \\
\hline 15 & 0.00 & 0.01 & 0.00 & 0.06 & 0.00 & 0.00 & 0.00 & 0.00 & 0.00 & 0.00 & 0.00 & 0.00 \\
\hline 16 & 0.00 & 0.00 & 0.00 & 0.01 & 0.00 & 0.00 & 0.00 & 0.00 & 0.00 & 0.00 & 0.00 & 0.00 \\
\hline 17 & 0.00 & 0.01 & 0.00 & 0.00 & 0.00 & 0.00 & 0.00 & 0.00 & 0.00 & 0.00 & 0.00 & 0.00 \\
\hline 18 & 0.00 & 0.00 & 0.00 & 0.00 & 0.00 & 0.00 & 0.00 & 0.00 & 0.00 & 0.00 & 0.00 & 0.12 \\
\hline 19 & 0.00 & 0.00 & 0.00 & 0.00 & 0.00 & 0.00 & 0.00 & 0.00 & 0.00 & 0.02 & 0.00 & 0.35 \\
\hline 20 & 0.00 & 0.00 & 0.00 & 0.12 & 0.00 & 0.00 & 0.00 & 0.00 & 0.00 & 0.03 & 0.00 & 0.01 \\
\hline 21 & 0.00 & 0.00 & 0.00 & 0.00 & 0.05 & 0.00 & 0.00 & 0.00 & 0.00 & 0.00 & 0.00 & 0.00 \\
\hline 22 & 0.00 & 0.00 & 0.00 & 0.00 & 0.01 & 0.00 & 0.00 & 0.00 & 0.00 & 0.50 & 0.00 & 0.00 \\
\hline 23 & 0.00 & 0.00 & 0.00 & 0.00 & 0.62 & 0.00 & 0.01 & 0.00 & 0.00 & 0.09 & 0.00 & 0.00 \\
\hline 24 & 0.00 & 0.00 & 0.00 & 0.00 & 0.86 & 0.00 & 0.00 & 0.00 & 0.00 & 0.43 & 0.00 & 0.00 \\
\hline 25 & 0.00 & 0.00 & 0.00 & 0.07 & 0.00 & 0.00 & 0.00 & 0.00 & 0.00 & 0.22 & 0.00 & 0.00 \\
\hline 26 & 0.00 & 0.00 & 0.00 & 0.00 & 0.00 & 0.00 & 0.00 & 0.00 & 0.00 & 0.00 & 0.00 & 0.00 \\
\hline 27 & 0.00 & 0.00 & 0.00 & 0.00 & 0.00 & 0.00 & 0.00 & 0.00 & 0.01 & 0.07 & 0.00 & 0.00 \\
\hline 28 & 0.00 & 0.00 & 0.00 & 0.00 & 0.12 & 0.00 & 0.00 & 0.00 & 0.00 & 0.00 & 0.00 & 0.00 \\
\hline 29 & 0.00 & 0.00 & 0.00 & 0.00 & 0.00 & 0.00 & 0.00 & 0.00 & 0.21 & 0.00 & 0.00 & 0.16 \\
\hline 30 & 0.00 & 0.00 & 0.00 & 0.00 & --- & 0.00 & 0.00 & 0.00 & 0.00 & 0.00 & 0.00 & 0.00 \\
\hline 31 & 0.00 & --- & 0.00 & 0.00 & --- & 0.00 & --- & 0.00 & --- & 0.00 & 0.00 & --- \\
\hline TOTAL & 1.03 & 0.84 & 0.27 & 0.26 & 1.69 & 1.60 & 3.58 & 0.03 & 0.22 & 1.36 & 0.17 & 0.73 \\
\hline MAX & 0.78 & 0.63 & 0.22 & 0.12 & 0.86 & 1.21 & 1.86 & 0.03 & 0.21 & 0.50 & 0.07 & 0.35 \\
\hline MIN & 0.00 & 0.00 & 0.00 & 0.00 & 0.00 & 0.00 & 0.00 & 0.00 & 0.00 & 0.00 & 0.00 & 0.00 \\
\hline
\end{tabular}

CAL YR 2003 TOTAL 9.50 MAX 0.82 MIN 0.00

WTR YR 2004 TOTAL 11.78 MAX 1.86 MIN 0.00 
Location.--35 $03^{\prime} 10^{\prime \prime} \mathrm{N}, 106^{\circ} 43^{\prime} 49^{\prime \prime} \mathrm{W}$. The rain gage is located in southwest Albuquerque, in the maintenance yard of the Leavitt Pump Station. The pump station is located near the southern end of 86th Street.

Equipment.--Onset Corporation HOBO Event data recorder and 6.5-inch-diameter tipping bucket. The bucket tips one time per 0.01 inch of rain, and the recorder stores data at 5-minute intervals. Rain gage is calibrated approximately every 2 years and was last calibrated in March 2003.

Record.--The rain gage gave a complete and satisfactory record for the water year.

Period of Record.--August 2000 to present.

Remarks.--Record is good for the entire water year.

PRECIPITATION, TOTAL, INCHES, WATER YEAR OCTOBER 2003 TO SEPTEMBER 2004 DAILY SUM VALUES

\begin{tabular}{|c|c|c|c|c|c|c|c|c|c|c|c|c|}
\hline DAY & OCT & NOV & DEC & JAN & FEB & MAR & APR & MAY & JUN & JUL & AUG & SEP \\
\hline 1 & 0.00 & 0.01 & 0.00 & 0.00 & 0.00 & 0.00 & 0.00 & 0.00 & 0.00 & 0.00 & 0.00 & 0.00 \\
\hline 2 & 0.00 & 0.00 & 0.00 & 0.00 & 0.00 & 0.16 & 0.55 & 0.00 & 0.00 & 0.00 & 0.14 & 0.00 \\
\hline 3 & 0.10 & 0.00 & 0.00 & 0.00 & 0.07 & 0.02 & 1.17 & 0.00 & 0.00 & 0.00 & 0.01 & 0.00 \\
\hline 4 & 0.02 & 0.00 & 0.00 & 0.00 & 0.00 & 0.60 & 0.20 & 0.00 & 0.01 & 0.00 & 0.00 & 0.13 \\
\hline 5 & 0.00 & 0.00 & 0.00 & 0.00 & 0.00 & 0.01 & 0.00 & 0.00 & 0.00 & 0.00 & 0.03 & 0.00 \\
\hline 6 & 0.00 & 0.00 & 0.00 & 0.00 & 0.00 & 0.00 & 0.00 & 0.00 & 0.00 & 0.00 & 0.01 & 0.00 \\
\hline 7 & 0.55 & 0.00 & 0.00 & 0.00 & 0.00 & 0.00 & 0.01 & 0.00 & 0.00 & 0.00 & 0.00 & 0.00 \\
\hline 8 & 0.22 & 0.00 & 0.03 & 0.00 & 0.00 & 0.00 & 0.30 & 0.00 & 0.00 & 0.02 & 0.00 & 0.00 \\
\hline 9 & 0.00 & 0.00 & 0.00 & 0.00 & 0.00 & 0.00 & 0.01 & 0.00 & 0.00 & 0.00 & 0.00 & 0.00 \\
\hline 10 & 0.37 & 0.01 & 0.00 & 0.00 & 0.00 & 0.00 & 0.39 & 0.00 & 0.00 & 0.00 & 0.26 & 0.00 \\
\hline 11 & 0.01 & 0.00 & 0.01 & 0.00 & 0.00 & 0.00 & 0.00 & 0.00 & 0.00 & 0.00 & 0.01 & 0.00 \\
\hline 12 & 0.00 & 0.57 & 0.14 & 0.00 & 0.00 & 0.00 & 0.00 & 0.00 & 0.00 & 0.22 & 0.00 & 0.00 \\
\hline 13 & 0.00 & 0.19 & 0.00 & 0.00 & 0.00 & 0.00 & 0.00 & 0.00 & 0.00 & 0.00 & 0.01 & 0.00 \\
\hline 14 & 0.00 & 0.00 & 0.00 & 0.00 & 0.00 & 0.00 & 0.00 & 0.00 & 0.00 & 0.00 & 0.00 & 0.00 \\
\hline 15 & 0.00 & 0.01 & 0.00 & 0.08 & 0.00 & 0.00 & 0.00 & 0.00 & 0.00 & 0.10 & 0.07 & 0.00 \\
\hline 16 & 0.00 & 0.00 & 0.00 & 0.02 & 0.00 & 0.00 & 0.00 & 0.00 & 0.00 & 0.00 & 0.00 & 0.00 \\
\hline 17 & 0.00 & 0.01 & 0.00 & 0.00 & 0.00 & 0.00 & 0.00 & 0.00 & 0.00 & 0.00 & 0.00 & 0.00 \\
\hline 18 & 0.00 & 0.00 & 0.00 & 0.00 & 0.00 & 0.00 & 0.00 & 0.00 & 0.00 & 0.05 & 0.04 & 0.24 \\
\hline 19 & 0.00 & 0.00 & 0.00 & 0.00 & 0.00 & 0.00 & 0.00 & 0.00 & 0.00 & 0.01 & 0.03 & 0.41 \\
\hline 20 & 0.00 & 0.00 & 0.00 & 0.06 & 0.00 & 0.00 & 0.00 & 0.00 & 0.00 & 0.12 & 0.03 & 0.04 \\
\hline 21 & 0.00 & 0.00 & 0.00 & 0.01 & 0.04 & 0.00 & 0.00 & 0.00 & 0.00 & 0.09 & 0.00 & 0.00 \\
\hline 22 & 0.00 & 0.00 & 0.00 & 0.00 & 0.00 & 0.00 & 0.00 & 0.00 & 0.01 & 0.58 & 0.00 & 0.00 \\
\hline 23 & 0.00 & 0.00 & 0.00 & 0.00 & 0.53 & 0.04 & 0.03 & 0.00 & 0.00 & 0.17 & 0.00 & 0.00 \\
\hline 24 & 0.00 & 0.00 & 0.00 & 0.00 & 0.34 & 0.00 & 0.01 & 0.00 & 0.00 & 0.61 & 0.00 & 0.00 \\
\hline 25 & 0.00 & 0.00 & 0.00 & 0.00 & 0.01 & 0.00 & 0.00 & 0.00 & 0.00 & 0.30 & 0.00 & 0.00 \\
\hline 26 & 0.00 & 0.00 & 0.00 & 0.00 & 0.00 & 0.00 & 0.00 & 0.00 & 0.00 & 0.00 & 0.00 & 0.00 \\
\hline 27 & 0.00 & 0.00 & 0.00 & 0.00 & 0.00 & 0.00 & 0.00 & 0.00 & 0.00 & 0.07 & 0.00 & 0.00 \\
\hline 28 & 0.00 & 0.00 & 0.00 & 0.00 & 0.06 & 0.00 & 0.00 & 0.00 & 0.00 & 0.00 & 0.00 & 0.00 \\
\hline 29 & 0.00 & 0.00 & 0.00 & 0.00 & 0.00 & 0.00 & 0.00 & 0.00 & 0.39 & 0.00 & 0.08 & 0.01 \\
\hline 30 & 0.00 & 0.00 & 0.00 & 0.00 & --- & 0.00 & 0.00 & 0.00 & 0.00 & 0.00 & 0.00 & 0.00 \\
\hline 31 & 0.00 & --- & 0.00 & 0.00 & --- & 0.00 & --- & 0.00 & --- & 0.00 & 0.00 & --- \\
\hline TOTAL & 1.27 & 0.80 & 0.18 & 0.17 & 1.05 & 0.83 & 2.67 & 0.00 & 0.41 & 2.34 & 0.72 & 0.83 \\
\hline MAX & 0.55 & 0.57 & 0.14 & 0.08 & 0.53 & 0.60 & 1.17 & 0.00 & 0.39 & 0.61 & 0.26 & 0.41 \\
\hline MIN & 0.00 & 0.00 & 0.00 & 0.00 & 0.00 & 0.00 & 0.00 & 0.00 & 0.00 & 0.00 & 0.00 & 0.00 \\
\hline
\end{tabular}

CAL YR 2003 TOTAL 6.96 MAX 1.20 MIN 0.00

WTR YR 2004 TOTAL 11.27 MAX 1.17 MIN 0.00 


\section{0, LEONARD RAIN GAGE IN ALBUQUERQUE, NEW MEXICO \\ STATION ANALYSIS \\ WATER YEAR 2004}

Location.--35 $07^{\prime} 21^{\prime \prime} \mathrm{N}, 106^{\circ} 33^{\prime} 55^{\prime} \mathrm{W}$. The rain gage is located in northeast Albuquerque at a private residence, approximately 0.25 mile northeast of the intersection of Louisiana and Montgomery Boulevards.

Equipment.--Onset Corporation HOBO Event data recorder and 7.9-inch-diameter tipping bucket. The bucket tips one time per 0.01 inch of rain, and the recorder stores data at 5 -minute intervals. Rain gage is calibrated approximately every 2 years and was last calibrated in March 2003.

Record.--The rain gage gave a complete and satisfactory record for the water year.

Period of Record.--April 1984 to present.

Remarks.--Record is good for the entire water year.

PRECIPITATION, TOTAL, INCHES, WATER YEAR OCTOBER 2003 TO SEPTEMBER 2004 DAILY SUM VALUES

\begin{tabular}{|c|c|c|c|c|c|c|c|c|c|c|c|c|}
\hline DAY & OCT & NOV & DEC & JAN & FEB & MAR & APR & MAY & JUN & JUL & AUG & SEP \\
\hline 1 & 0.00 & 0.00 & 0.00 & 0.00 & 0.05 & 0.00 & 0.00 & 0.00 & 0.00 & 0.00 & 0.00 & 0.00 \\
\hline 2 & 0.00 & 0.00 & 0.00 & 0.00 & 0.00 & 0.06 & 0.20 & 0.00 & 0.00 & 0.00 & 0.04 & 0.00 \\
\hline 3 & 0.03 & 0.00 & 0.00 & 0.00 & 0.00 & 0.00 & 0.71 & 0.00 & 0.00 & 0.00 & 0.00 & 0.00 \\
\hline 4 & 0.00 & 0.00 & 0.00 & 0.00 & 0.07 & 0.58 & 0.10 & 0.00 & 0.00 & 0.00 & 0.07 & 0.06 \\
\hline 5 & 0.00 & 0.00 & 0.00 & 0.00 & 0.00 & 0.07 & 0.00 & 0.00 & 0.00 & 0.00 & 0.00 & 0.00 \\
\hline 6 & 0.00 & 0.00 & 0.00 & 0.00 & 0.00 & 0.00 & 0.00 & 0.00 & 0.00 & 0.00 & 0.00 & 0.00 \\
\hline 7 & 0.71 & 0.00 & 0.00 & 0.00 & 0.00 & 0.00 & 0.00 & 0.00 & 0.00 & 0.00 & 0.00 & 0.00 \\
\hline 8 & 0.13 & 0.00 & 0.00 & 0.00 & 0.00 & 0.00 & 0.26 & 0.00 & 0.00 & 0.00 & 0.00 & 0.00 \\
\hline 9 & 0.00 & 0.00 & 0.00 & 0.00 & 0.00 & 0.00 & 0.04 & 0.00 & 0.00 & 0.00 & 0.00 & 0.00 \\
\hline 10 & 0.13 & 0.00 & 0.00 & 0.00 & 0.00 & 0.00 & 0.21 & 0.00 & 0.00 & 0.00 & 0.06 & 0.00 \\
\hline 11 & 0.00 & 0.00 & 0.00 & 0.00 & 0.00 & 0.00 & 0.00 & 0.00 & 0.00 & 0.00 & 0.00 & 0.00 \\
\hline 12 & 0.00 & 0.39 & 0.10 & 0.00 & 0.00 & 0.00 & 0.00 & 0.00 & 0.00 & 0.61 & 0.00 & 0.00 \\
\hline 13 & 0.00 & 0.15 & 0.00 & 0.00 & 0.00 & 0.00 & 0.00 & 0.00 & 0.00 & 0.00 & 0.00 & 0.00 \\
\hline 14 & 0.00 & 0.00 & 0.00 & 0.00 & 0.00 & 0.00 & 0.00 & 0.00 & 0.00 & 0.10 & 0.00 & 0.00 \\
\hline 15 & 0.00 & 0.00 & 0.00 & 0.00 & 0.00 & 0.00 & 0.00 & 0.00 & 0.00 & 0.09 & 0.00 & 0.00 \\
\hline 16 & 0.00 & 0.04 & 0.00 & 0.00 & 0.00 & 0.00 & 0.00 & 0.00 & 0.00 & 0.00 & 0.00 & 0.00 \\
\hline 17 & 0.00 & 0.00 & 0.00 & 0.00 & 0.00 & 0.00 & 0.00 & 0.00 & 0.00 & 0.00 & 0.00 & 0.00 \\
\hline 18 & 0.00 & 0.00 & 0.00 & 0.00 & 0.00 & 0.00 & 0.00 & 0.00 & 0.00 & 0.00 & 0.00 & 0.08 \\
\hline 19 & 0.00 & 0.00 & 0.00 & 0.00 & 0.00 & 0.00 & 0.00 & 0.00 & 0.00 & 0.00 & 0.00 & 0.86 \\
\hline 20 & 0.00 & 0.00 & 0.00 & 0.04 & 0.00 & 0.00 & 0.00 & 0.00 & 0.00 & 0.05 & 0.00 & 0.03 \\
\hline 21 & 0.00 & 0.00 & 0.00 & 0.00 & 0.04 & 0.00 & 0.00 & 0.00 & 0.00 & 0.01 & 0.10 & 0.00 \\
\hline 22 & 0.00 & 0.00 & 0.00 & 0.00 & 0.00 & 0.00 & 0.00 & 0.00 & 0.00 & 0.00 & 0.00 & 0.00 \\
\hline 23 & 0.00 & 0.00 & 0.00 & 0.00 & 0.68 & 0.02 & 0.00 & 0.00 & 0.00 & 0.66 & 0.00 & 0.00 \\
\hline 24 & 0.00 & 0.00 & 0.00 & 0.00 & 0.30 & 0.00 & 0.00 & 0.00 & 0.00 & 0.11 & 0.00 & 0.00 \\
\hline 25 & 0.00 & 0.00 & 0.00 & 0.02 & 0.00 & 0.00 & 0.00 & 0.00 & 0.00 & 0.18 & 0.00 & 0.00 \\
\hline 26 & 0.00 & 0.00 & 0.00 & 0.00 & 0.00 & 0.00 & 0.00 & 0.00 & 0.17 & 0.00 & 0.00 & 0.00 \\
\hline 27 & 0.00 & 0.00 & 0.00 & 0.00 & 0.00 & 0.00 & 0.00 & 0.00 & 0.00 & 0.72 & 0.00 & 0.00 \\
\hline 28 & 0.00 & 0.00 & 0.00 & 0.00 & 0.10 & 0.00 & 0.00 & 0.00 & 0.01 & 0.00 & 0.00 & 0.00 \\
\hline 29 & 0.00 & 0.00 & 0.00 & 0.00 & 0.00 & 0.00 & 0.00 & 0.00 & 0.30 & 0.00 & 0.00 & 0.00 \\
\hline 30 & 0.00 & 0.00 & 0.00 & 0.00 & --- & 0.00 & 0.00 & 0.00 & 0.00 & 0.00 & 0.00 & 0.00 \\
\hline 31 & 0.00 & --- & 0.00 & 0.00 & --- & 0.00 & --- & 0.00 & --- & 0.00 & 0.00 & --- \\
\hline TOTAL & 1.00 & 0.58 & 0.10 & 0.06 & 1.24 & 0.73 & 1.52 & 0.00 & 0.48 & 2.53 & 0.27 & 1.03 \\
\hline MAX & 0.71 & 0.39 & 0.10 & 0.04 & 0.68 & 0.58 & 0.71 & 0.00 & 0.30 & 0.72 & 0.10 & 0.86 \\
\hline MIN & 0.00 & 0.00 & 0.00 & 0.00 & 0.00 & 0.00 & 0.00 & 0.00 & 0.00 & 0.00 & 0.00 & 0.00 \\
\hline
\end{tabular}

CAL YR 2003 TOTAL 4.68 MAX 0.71 MIN 0.00

WTR YR 2004 TOTAL 9.54 MAX 0.86 MIN 0.00 


\section{0, LOVE PUMP STATION RAIN GAGE AT ALBUQUERQUE, NEW MEXICO STATION ANALYSIS \\ WATER YEAR 2004}

Location.--35 $05^{\prime} 40^{\prime \prime} \mathrm{N}, 106^{\circ} 33^{\prime} 32^{\prime \prime} \mathrm{W}$. The rain gage is located in northeast Albuquerque near the intersection of Pennsylvania Street and Constitution Avenue.

Equipment.--Onset Corporation HOBO Event data recorder and 6.5-inch-diameter tipping bucket. The bucket tips one time per 0.01 inch of rain, and the recorder stores data at 5 -minute intervals. Rain gage is calibrated approximately every 2 years and was last calibrated in March 2003.

Record.--The rain gage gave a complete and satisfactory record for the period of record.

Period of Record.--September 2002 to present.

Remarks.--Record is good for the period of record.

PRECIPITATION, TOTAL, INCHES, WATER YEAR OCTOBER 2003 TO SEPTEMBER 2004 DAILY SUM VALUES

\begin{tabular}{|c|c|c|c|c|c|c|c|c|c|c|c|c|}
\hline DAY & ОСт & NOV & DEC & JAN & FEB & MAR & APR & MAY & JUN & JUL & AUG & SEP \\
\hline 1 & 0.00 & 0.00 & 0.00 & 0.00 & 0.01 & 0.00 & 0.00 & 0.00 & 0.00 & 0.00 & 0.00 & 0.00 \\
\hline 2 & 0.00 & 0.00 & 0.00 & 0.00 & 0.00 & 0.05 & 0.21 & 0.00 & 0.00 & 0.00 & 0.08 & 0.00 \\
\hline 3 & 0.07 & 0.00 & 0.00 & 0.00 & 0.02 & 0.00 & 0.86 & 0.00 & 0.00 & 0.00 & 0.00 & 0.00 \\
\hline 4 & 0.01 & 0.00 & 0.00 & 0.00 & 0.03 & 0.86 & 0.16 & 0.00 & 0.00 & 0.00 & 0.16 & 0.10 \\
\hline 5 & 0.00 & 0.00 & 0.00 & 0.00 & 0.00 & 0.03 & 0.00 & 0.00 & 0.00 & 0.00 & 0.00 & 0.00 \\
\hline 6 & 0.00 & 0.00 & 0.00 & 0.00 & 0.00 & 0.00 & 0.00 & 0.00 & 0.00 & 0.00 & 0.00 & 0.00 \\
\hline 7 & 1.03 & 0.00 & 0.00 & 0.00 & 0.00 & 0.00 & 0.00 & 0.00 & 0.00 & 0.00 & 0.00 & 0.00 \\
\hline 8 & 0.19 & 0.00 & 0.03 & 0.00 & 0.00 & 0.00 & 0.30 & 0.00 & 0.00 & 0.00 & 0.00 & 0.00 \\
\hline 9 & 0.00 & 0.00 & 0.00 & 0.00 & 0.00 & 0.00 & 0.01 & 0.00 & 0.00 & 0.00 & 0.00 & 0.00 \\
\hline 10 & 0.16 & 0.00 & 0.00 & 0.00 & 0.00 & 0.00 & 0.10 & 0.00 & 0.00 & 0.00 & 0.38 & 0.00 \\
\hline 11 & 0.00 & 0.02 & 0.00 & 0.00 & 0.00 & 0.00 & 0.00 & 0.00 & 0.00 & 0.03 & 0.01 & 0.00 \\
\hline 12 & 0.00 & 0.50 & 0.14 & 0.00 & 0.00 & 0.01 & 0.00 & 0.00 & 0.00 & 0.26 & 0.00 & 0.00 \\
\hline 13 & 0.00 & 0.17 & 0.00 & 0.00 & 0.00 & 0.00 & 0.00 & 0.00 & 0.00 & 0.00 & 0.00 & 0.00 \\
\hline 14 & 0.00 & 0.00 & 0.00 & 0.00 & 0.00 & 0.00 & 0.00 & 0.00 & 0.00 & 0.03 & 0.00 & 0.00 \\
\hline 15 & 0.00 & 0.00 & 0.00 & 0.02 & 0.00 & 0.00 & 0.00 & 0.00 & 0.00 & 1.06 & 0.00 & 0.00 \\
\hline 16 & 0.00 & 0.03 & 0.00 & 0.01 & 0.00 & 0.00 & 0.00 & 0.00 & 0.00 & 0.00 & 0.00 & 0.00 \\
\hline 17 & 0.00 & 0.00 & 0.00 & 0.00 & 0.00 & 0.00 & 0.00 & 0.00 & 0.00 & 0.00 & 0.00 & 0.00 \\
\hline 18 & 0.00 & 0.00 & 0.00 & 0.00 & 0.00 & 0.00 & 0.00 & 0.00 & 0.00 & 0.03 & 0.00 & 0.04 \\
\hline 19 & 0.00 & 0.00 & 0.00 & 0.00 & 0.00 & 0.00 & 0.00 & 0.00 & 0.00 & 0.00 & 0.03 & 0.85 \\
\hline 20 & 0.00 & 0.00 & 0.00 & 0.08 & 0.00 & 0.00 & 0.00 & 0.00 & 0.00 & 0.08 & 0.00 & 0.06 \\
\hline 21 & 0.00 & 0.00 & 0.00 & 0.00 & 0.06 & 0.00 & 0.00 & 0.00 & 0.00 & 0.00 & 0.00 & 0.00 \\
\hline 22 & 0.00 & 0.00 & 0.00 & 0.00 & 0.00 & 0.00 & 0.00 & 0.00 & 0.00 & 0.42 & 0.00 & 0.00 \\
\hline 23 & 0.00 & 0.00 & 0.00 & 0.00 & 0.87 & 0.06 & 0.00 & 0.00 & 0.00 & 0.99 & 0.00 & 0.00 \\
\hline 24 & 0.00 & 0.00 & 0.00 & 0.00 & 0.44 & 0.00 & 0.00 & 0.00 & 0.00 & 0.12 & 0.00 & 0.00 \\
\hline 25 & 0.00 & 0.00 & 0.00 & 0.06 & 0.00 & 0.00 & 0.00 & 0.00 & 0.00 & 0.52 & 0.00 & 0.00 \\
\hline 26 & 0.00 & 0.00 & 0.00 & 0.00 & 0.00 & 0.00 & 0.00 & 0.00 & 0.04 & 0.00 & 0.00 & 0.02 \\
\hline 27 & 0.00 & 0.00 & 0.00 & 0.00 & 0.00 & 0.00 & 0.00 & 0.00 & 0.00 & 0.40 & 0.00 & 0.00 \\
\hline 28 & 0.00 & 0.00 & 0.00 & 0.00 & 0.16 & 0.00 & 0.00 & 0.00 & 0.04 & 0.00 & 0.00 & 0.00 \\
\hline 29 & 0.00 & 0.00 & 0.00 & 0.00 & 0.00 & 0.00 & 0.00 & 0.00 & 0.53 & 0.00 & 0.00 & 0.00 \\
\hline 30 & 0.00 & 0.00 & 0.00 & 0.00 & --- & 0.00 & 0.00 & 0.00 & 0.00 & 0.00 & 0.00 & 0.01 \\
\hline 31 & 0.00 & --- & 0.00 & 0.00 & --- & 0.00 & --- & 0.00 & --- & 0.00 & 0.00 & --- \\
\hline TOTAL & 1.46 & 0.72 & 0.17 & 0.17 & 1.59 & 1.01 & 1.64 & 0.00 & 0.61 & 3.94 & 0.66 & 1.08 \\
\hline MAX & 1.03 & 0.50 & 0.14 & 0.08 & 0.87 & 0.86 & 0.86 & 0.00 & 0.53 & 1.06 & 0.38 & 0.85 \\
\hline MIN & 0.00 & 0.00 & 0.00 & 0.00 & 0.00 & 0.00 & 0.00 & 0.00 & 0.00 & 0.00 & 0.00 & 0.00 \\
\hline
\end{tabular}

CAL YR 2003 TOTAL 6.81 MAX 1.03 MIN 0.00

WTR YR 2004 TOTAL 13.05 MAX 1.06 MIN 0.00 
08329914, NORTH CAMINO ARROYO TRIBUTARY AT WYOMING BOULEVARD RAIN GAGE AT

ALBUQUERQUE, NEW MEXICO

STATION ANALYSIS

WATER YEAR 2004

Location.--35 $11^{\prime} 44^{\prime \prime} \mathrm{N}, 106^{\circ} 33^{\prime} 36^{\prime \prime} \mathrm{W}$. The rain gage is located in northeast Albuquerque on Wyoming Boulevard, approximately 2 miles north of Paseo del Norte.

Equipment.--Onset Corporation HOBO Event data recorder and 8.1-inch-diameter tipping bucket. The bucket tips one time per 0.01 inch of rain, and the recorder stores data at 5-minute intervals. Rain gage is calibrated approximately every 2 years and was last calibrated in March 2003.

Record.--The rain gage gave a complete and satisfactory record for the entire water year except for May 25 to June 22. During this period the rain gage installation was vandalized. Estimated daily totals for these days are the averages of daily totals from the North Floodway nr. Alameda and Walker Pump rain gages.

Period of Record.--October 1988 to present.

Remarks.--Record is good for the entire water year including estimates.

PRECIPITATION, TOTAL, INCHES, WATER YEAR OCTOBER 2003 TO SEPTEMBER 2004 DAILY SUM VALUES

\begin{tabular}{|c|c|c|c|c|c|c|c|c|c|c|c|c|}
\hline DAY & ОСт & Nov & $\mathrm{DEC}$ & JAN & FEB & MAR & APR & MAY & JUN & JUL & AUG & SEP \\
\hline 1 & 0.00 & 0.00 & 0.00 & 0.00 & 0.00 & 0.00 & 0.00 & 0.00 & $\mathrm{e} 0.00$ & 0.00 & 0.00 & 0.00 \\
\hline 2 & 0.00 & 0.00 & 0.00 & 0.00 & 0.00 & 0.19 & 0.30 & 0.00 & e0.00 & 0.00 & 0.06 & 0.00 \\
\hline 3 & 0.07 & 0.00 & 0.00 & 0.00 & 0.00 & 0.01 & 0.62 & 0.00 & e0.00 & 0.00 & 0.00 & 0.00 \\
\hline 4 & 0.03 & 0.00 & 0.00 & 0.00 & 0.12 & 0.84 & 0.13 & 0.00 & $\mathrm{e} 0.00$ & 0.00 & 0.16 & 0.02 \\
\hline 5 & 0.00 & 0.00 & 0.00 & 0.00 & 0.00 & 0.03 & 0.00 & 0.00 & e0.00 & 0.00 & 0.02 & 0.00 \\
\hline 6 & 0.00 & 0.00 & 0.00 & 0.00 & 0.00 & 0.00 & 0.00 & 0.00 & e0.00 & 0.00 & 0.00 & 0.00 \\
\hline 7 & 0.51 & 0.00 & 0.00 & 0.00 & 0.00 & 0.00 & 0.00 & 0.00 & $\mathrm{e} 0.00$ & 0.00 & 0.00 & 0.00 \\
\hline 8 & 0.20 & 0.00 & 0.06 & 0.00 & 0.00 & 0.00 & 0.23 & 0.00 & $\mathrm{e} 0.00$ & 0.00 & 0.00 & 0.00 \\
\hline 9 & 0.00 & 0.00 & 0.00 & 0.00 & 0.00 & 0.00 & 0.06 & 0.00 & e0.00 & 0.00 & 0.00 & 0.00 \\
\hline 10 & 0.07 & 0.00 & 0.00 & 0.00 & 0.00 & 0.00 & 0.42 & 0.00 & $\mathrm{e} 0.00$ & 0.00 & 0.01 & 0.00 \\
\hline 11 & 0.00 & 0.00 & 0.00 & 0.00 & 0.00 & 0.00 & 0.00 & 0.00 & e0.00 & 0.00 & 0.00 & 0.00 \\
\hline 12 & 0.00 & 0.54 & 0.13 & 0.00 & 0.00 & 0.00 & 0.00 & 0.00 & $\mathrm{e} 0.00$ & 0.64 & 0.03 & 0.00 \\
\hline 13 & 0.00 & 0.28 & 0.00 & 0.00 & 0.00 & 0.00 & 0.00 & 0.00 & $\mathrm{e} 0.00$ & 0.00 & 0.00 & 0.00 \\
\hline 14 & 0.00 & 0.00 & 0.00 & 0.00 & 0.00 & 0.00 & 0.00 & 0.00 & $\mathrm{e} 0.00$ & 0.00 & 0.00 & 0.00 \\
\hline 15 & 0.00 & 0.00 & 0.00 & 0.07 & 0.00 & 0.00 & 0.00 & 0.01 & $\mathrm{e} 0.00$ & 0.00 & 0.00 & 0.00 \\
\hline 16 & 0.00 & 0.02 & 0.00 & 0.02 & 0.00 & 0.00 & 0.00 & 0.00 & $\mathrm{e} 0.00$ & 0.00 & 0.00 & 0.00 \\
\hline 17 & 0.00 & 0.01 & 0.00 & 0.00 & 0.00 & 0.00 & 0.00 & 0.00 & $\mathrm{e} 0.00$ & 0.00 & 0.00 & 0.00 \\
\hline 18 & 0.00 & 0.00 & 0.00 & 0.00 & 0.00 & 0.00 & 0.00 & 0.00 & $\mathrm{e} 0.00$ & 0.01 & 0.04 & 0.05 \\
\hline 19 & 0.00 & 0.00 & 0.00 & 0.00 & 0.00 & 0.00 & 0.00 & 0.00 & $\mathrm{e} 0.00$ & 0.00 & 0.00 & 0.71 \\
\hline 20 & 0.00 & 0.00 & 0.00 & 0.10 & 0.00 & 0.00 & 0.00 & 0.00 & $\mathrm{e} 0.00$ & 0.09 & 0.00 & 0.03 \\
\hline 21 & 0.00 & 0.00 & 0.00 & 0.00 & 0.09 & 0.00 & 0.00 & 0.00 & $\mathrm{e} 0.00$ & 0.00 & 0.00 & 0.00 \\
\hline 22 & 0.00 & 0.00 & 0.00 & 0.00 & 0.00 & 0.00 & 0.00 & 0.00 & $\mathrm{e} 0.00$ & 0.00 & 0.00 & 0.00 \\
\hline 23 & 0.00 & 0.00 & 0.00 & 0.00 & 0.55 & 0.08 & 0.01 & 0.00 & 0.00 & 0.87 & 0.00 & 0.00 \\
\hline 24 & 0.00 & 0.00 & 0.00 & 0.00 & 0.35 & 0.00 & 0.00 & 0.00 & 0.00 & 0.55 & 0.00 & 0.00 \\
\hline 25 & 0.00 & 0.00 & 0.00 & 0.06 & 0.00 & 0.00 & 0.00 & e 0.00 & 0.00 & 0.21 & 0.00 & 0.00 \\
\hline 26 & 0.00 & 0.00 & 0.00 & 0.00 & 0.00 & 0.00 & 0.00 & e0.00 & 0.25 & 0.00 & 0.00 & 0.00 \\
\hline 27 & 0.00 & 0.00 & 0.00 & 0.00 & 0.00 & 0.00 & 0.00 & e0.00 & 0.00 & 0.43 & 0.00 & 0.00 \\
\hline 28 & 0.00 & 0.00 & 0.00 & 0.02 & 0.18 & 0.00 & 0.00 & $\mathrm{e} 0.00$ & 0.00 & 0.00 & 0.00 & 0.00 \\
\hline 29 & 0.00 & 0.00 & 0.00 & 0.00 & 0.00 & 0.00 & 0.00 & e0.00 & 0.75 & 0.00 & 0.00 & 0.19 \\
\hline 30 & 0.00 & 0.00 & 0.00 & 0.00 & --- & 0.00 & 0.00 & $\mathrm{e} 0.00$ & 0.00 & 0.00 & 0.00 & 0.01 \\
\hline 31 & 0.00 & --- & 0.00 & 0.00 & --- & 0.00 & --- & e0.00 & --- & 0.00 & 0.00 & --- \\
\hline TOTAL & 0.88 & 0.85 & 0.19 & 0.27 & 1.29 & 1.15 & 1.77 & 0.01 & 1.00 & 2.80 & 0.32 & 1.01 \\
\hline MAX & 0.51 & 0.54 & 0.13 & 0.10 & 0.55 & 0.84 & 0.62 & 0.01 & 0.75 & 0.87 & 0.16 & 0.71 \\
\hline MIN & 0.00 & 0.00 & 0.00 & 0.00 & 0.00 & 0.00 & 0.00 & 0.00 & 0.00 & 0.00 & 0.00 & 0.00 \\
\hline
\end{tabular}

CAL YR 2003 TOTAL 11.78 MAX 2.22 MIN 0.00

WTR YR 2004 TOTAL 11.54 MAX 0.87 MIN 0.00 


\section{5, NORTH FLOODWAY CHANNEL RAIN GAGE AT ALBUQUERQUE, NEW MEXICO STATION ANALYSIS \\ WATER YEAR 2004}

Location.--35 $07^{\circ} 05^{\prime} \mathrm{N}, 106^{\circ} 36^{\prime} 42^{\prime}$ W. The rain gage is located in northeast Albuquerque at the surface-water gage, just north of the intersection of the North Floodway Channel and Candelaria Road.

Equipment.--8.0-inch-diameter tipping bucket connected to a surface-water data recorder. The bucket tips one time per 0.01 inch of rain, and the recorder stores data at 5-minute intervals. Rain gage is calibrated approximately every 2 years and was last calibrated in March 2003.

Record.--The rain gage gave a complete and satisfactory record for the water year.

Period of Record.--July 1999 to present.

Remarks.--Record is good for the entire water year.

PRECIPITATION, TOTAL, INCHES, WATER YEAR OCTOBER 2003 TO SEPTEMBER 2004 DAILY SUM VALUES

\begin{tabular}{|c|c|c|c|c|c|c|c|c|c|c|c|c|}
\hline DAY & ОСт & NOV & DEC & JAN & FEB & MAR & APR & MAY & JUN & JUL & AUG & $\mathrm{SEP}$ \\
\hline 1 & 0.00 & 0.00 & 0.00 & 0.00 & 0.02 & 0.00 & 0.00 & 0.00 & 0.00 & 0.00 & 0.00 & 0.00 \\
\hline 2 & 0.00 & 0.00 & 0.00 & 0.00 & 0.00 & 0.10 & 0.33 & 0.00 & 0.00 & 0.00 & 0.06 & 0.00 \\
\hline 3 & 0.09 & 0.00 & 0.00 & 0.00 & 0.03 & 0.00 & 1.52 & 0.00 & 0.00 & 0.00 & 0.00 & 0.00 \\
\hline 4 & 0.01 & 0.00 & 0.00 & 0.00 & 0.00 & 0.53 & 0.06 & 0.00 & 0.00 & 0.00 & 0.12 & 0.04 \\
\hline 5 & 0.00 & 0.00 & 0.00 & 0.00 & 0.00 & 0.06 & 0.01 & 0.00 & 0.00 & 0.00 & 0.01 & 0.01 \\
\hline 6 & 0.00 & 0.00 & 0.00 & 0.00 & 0.00 & 0.00 & 0.00 & 0.00 & 0.00 & 0.00 & 0.00 & 0.00 \\
\hline 7 & 1.00 & 0.00 & 0.00 & 0.00 & 0.00 & 0.00 & 0.00 & 0.00 & 0.00 & 0.00 & 0.00 & 0.00 \\
\hline 8 & 0.21 & 0.00 & 0.00 & 0.00 & 0.00 & 0.00 & 0.27 & 0.00 & 0.00 & 0.00 & 0.00 & 0.00 \\
\hline 9 & 0.00 & 0.00 & 0.00 & 0.00 & 0.00 & 0.00 & 0.01 & 0.00 & 0.00 & 0.00 & 0.00 & 0.00 \\
\hline 10 & 0.21 & 0.00 & 0.01 & 0.00 & 0.00 & 0.00 & 0.22 & 0.00 & 0.00 & 0.00 & 0.32 & 0.00 \\
\hline 11 & 0.00 & 0.00 & 0.00 & 0.00 & 0.00 & 0.00 & 0.00 & 0.00 & 0.00 & 0.00 & 0.01 & 0.00 \\
\hline 12 & 0.00 & 0.59 & 0.05 & 0.00 & 0.00 & 0.02 & 0.00 & 0.00 & 0.00 & 0.82 & 0.00 & 0.00 \\
\hline 13 & 0.00 & 0.20 & 0.00 & 0.00 & 0.00 & 0.00 & 0.00 & 0.00 & 0.00 & 0.01 & 0.00 & 0.00 \\
\hline 14 & 0.00 & 0.00 & 0.00 & 0.00 & 0.00 & 0.00 & 0.00 & 0.00 & 0.00 & 0.00 & 0.00 & 0.00 \\
\hline 15 & 0.00 & 0.00 & 0.02 & 0.02 & 0.00 & 0.00 & 0.00 & 0.00 & 0.00 & 0.11 & 0.00 & 0.00 \\
\hline 16 & 0.00 & 0.00 & 0.00 & 0.00 & 0.00 & 0.00 & 0.00 & 0.00 & 0.00 & 0.00 & 0.00 & 0.00 \\
\hline 17 & 0.00 & 0.00 & 0.00 & 0.01 & 0.00 & 0.00 & 0.01 & 0.00 & 0.00 & 0.00 & 0.00 & 0.00 \\
\hline 18 & 0.00 & 0.00 & 0.00 & 0.00 & 0.00 & 0.00 & 0.00 & 0.00 & 0.00 & 0.02 & 0.00 & 0.08 \\
\hline 19 & 0.00 & 0.00 & 0.00 & 0.00 & 0.00 & 0.00 & 0.00 & 0.00 & 0.00 & 0.00 & 0.13 & 0.77 \\
\hline 20 & 0.00 & 0.00 & 0.00 & 0.02 & 0.00 & 0.00 & 0.00 & 0.00 & 0.00 & 0.04 & 0.00 & 0.02 \\
\hline 21 & 0.00 & 0.00 & 0.00 & 0.01 & 0.03 & 0.00 & 0.00 & 0.00 & 0.00 & 0.00 & 0.00 & 0.00 \\
\hline 22 & 0.00 & 0.04 & 0.00 & 0.00 & 0.00 & 0.00 & 0.00 & 0.00 & 0.00 & 0.00 & 0.00 & 0.00 \\
\hline 23 & 0.00 & 0.00 & 0.00 & 0.00 & 0.97 & 0.01 & 0.00 & 0.00 & 0.00 & 1.06 & 0.00 & 0.00 \\
\hline 24 & 0.00 & 0.00 & 0.00 & 0.00 & 0.24 & 0.01 & 0.00 & 0.00 & 0.00 & 0.04 & 0.00 & 0.00 \\
\hline 25 & 0.00 & 0.00 & 0.00 & 0.02 & 0.00 & 0.00 & 0.00 & 0.00 & 0.00 & 0.36 & 0.00 & 0.00 \\
\hline 26 & 0.00 & 0.00 & 0.00 & 0.00 & 0.00 & 0.00 & 0.00 & 0.00 & 0.20 & 0.00 & 0.00 & 0.00 \\
\hline 27 & 0.00 & 0.00 & 0.00 & 0.00 & 0.00 & 0.00 & 0.00 & 0.00 & 0.00 & 0.20 & 0.00 & 0.00 \\
\hline 28 & 0.00 & 0.00 & 0.00 & 0.00 & 0.10 & 0.00 & 0.00 & 0.00 & 0.00 & 0.07 & 0.00 & 0.00 \\
\hline 29 & 0.00 & 0.00 & 0.00 & 0.00 & 0.00 & 0.00 & 0.00 & 0.00 & 0.56 & 0.00 & 0.00 & 0.18 \\
\hline 30 & 0.00 & 0.00 & 0.00 & 0.00 & --- & 0.00 & 0.00 & 0.00 & 0.00 & 0.00 & 0.00 & 0.00 \\
\hline 31 & 0.00 & --- & 0.00 & 0.00 & --- & 0.00 & --- & 0.00 & --- & 0.00 & 0.00 & --- \\
\hline TOTAL & 1.52 & 0.83 & 0.08 & 0.08 & 1.39 & 0.73 & 2.43 & 0.00 & 0.76 & 2.73 & 0.65 & 1.10 \\
\hline MAX & 1.00 & 0.59 & 0.05 & 0.02 & 0.97 & 0.53 & 1.52 & 0.00 & 0.56 & 1.06 & 0.32 & 0.77 \\
\hline MIN & 0.00 & 0.00 & 0.00 & 0.00 & 0.00 & 0.00 & 0.00 & 0.00 & 0.00 & 0.00 & 0.00 & 0.00 \\
\hline
\end{tabular}




\section{0, NORTH FLOODWAY CHANNEL RAIN GAGE NEAR ALAMEDA, ALBUQUERQUE, NEW MEXICO \\ STATION ANALYSIS \\ WATER YEAR 2004}

Location.-- $35^{\circ} 11^{\prime} 53^{\prime} \mathrm{N}, 106^{\circ} 35^{\prime} 59^{\prime}$ 'W. The rain gage is located in northeast Albuquerque at the surface-water gage, just east of the northern terminus of Edith Boulevard.

Equipment.--8.0-inch-diameter tipping bucket connected to a surface-water data recorder. The bucket tips one time per 0.01 inch of rain, and the recorder stores data at 5-minute intervals. Rain gage is calibrated approximately every 2 years and was last calibrated in March 2003.

Record.--The rain gage gave a complete and satisfactory record for the period of record except for November 12 to 18 ; during this period the data recorder malfunctioned. Estimated daily totals for these days are actual totals observed during gage inspections.

Period of Record.--December 2001 to present.

Remarks.--Record is good for the entire water year including estimated days.

PRECIPITATION, TOTAL, INCHES, WATER YEAR OCTOBER 2003 TO SEPTEMBER 2004 DAILY SUM VALUES

\begin{tabular}{|c|c|c|c|c|c|c|c|c|c|c|c|c|}
\hline DAY & ОСт & NOV & DEC & JAN & FEB & MAR & APR & MAY & JUN & JUL & AUG & SEP \\
\hline 1 & 0.00 & 0.00 & 0.00 & 0.00 & 0.00 & 0.00 & 0.00 & 0.00 & 0.00 & 0.00 & 0.00 & 0.00 \\
\hline 2 & 0.00 & 0.00 & 0.00 & 0.00 & 0.00 & 0.19 & 0.19 & 0.00 & 0.00 & 0.00 & 0.09 & 0.00 \\
\hline 3 & 0.08 & 0.00 & 0.00 & 0.00 & 0.09 & 0.01 & 1.10 & 0.00 & 0.00 & 0.00 & 0.00 & 0.00 \\
\hline 4 & 0.03 & 0.00 & 0.00 & 0.00 & 0.00 & 0.65 & 0.10 & 0.00 & 0.00 & 0.00 & 0.09 & 0.17 \\
\hline 5 & 0.00 & 0.00 & 0.00 & 0.00 & 0.00 & 0.02 & 0.00 & 0.00 & 0.00 & 0.00 & 0.04 & 0.00 \\
\hline 6 & 0.00 & 0.00 & 0.00 & 0.00 & 0.00 & 0.00 & 0.00 & 0.00 & 0.00 & 0.00 & 0.00 & 0.00 \\
\hline 7 & 0.75 & 0.00 & 0.00 & 0.00 & 0.00 & 0.00 & 0.00 & 0.00 & 0.00 & 0.00 & 0.00 & 0.00 \\
\hline 8 & 0.23 & 0.00 & 0.03 & 0.00 & 0.00 & 0.00 & 0.28 & 0.00 & 0.00 & 0.00 & 0.00 & 0.00 \\
\hline 9 & 0.00 & 0.00 & 0.00 & 0.00 & 0.00 & 0.00 & 0.06 & 0.00 & 0.00 & 0.00 & 0.00 & 0.00 \\
\hline 10 & 0.02 & 0.00 & 0.00 & 0.00 & 0.00 & 0.00 & 0.24 & 0.00 & 0.00 & 0.00 & 0.01 & 0.00 \\
\hline 11 & 0.00 & 0.00 & 0.00 & 0.00 & 0.00 & 0.00 & 0.00 & 0.00 & 0.00 & 0.00 & 0.00 & 0.00 \\
\hline 12 & 0.00 & e0.57 & 0.13 & 0.00 & 0.00 & 0.00 & 0.00 & 0.00 & 0.00 & 0.17 & 0.00 & 0.00 \\
\hline 13 & 0.00 & e0.24 & 0.00 & 0.00 & 0.00 & 0.00 & 0.00 & 0.00 & 0.00 & 0.00 & 0.03 & 0.00 \\
\hline 14 & 0.00 & e0.00 & 0.00 & 0.00 & 0.00 & 0.00 & 0.00 & 0.00 & 0.00 & 0.00 & 0.01 & 0.00 \\
\hline 15 & 0.00 & e0.00 & 0.00 & 0.04 & 0.00 & 0.00 & 0.00 & 0.00 & 0.00 & 0.00 & 0.00 & 0.00 \\
\hline 16 & 0.00 & e0.00 & 0.00 & 0.01 & 0.00 & 0.00 & 0.00 & 0.00 & 0.00 & 0.00 & 0.00 & 0.00 \\
\hline 17 & 0.00 & e0.02 & 0.00 & 0.00 & 0.00 & 0.00 & 0.00 & 0.00 & 0.00 & 0.00 & 0.00 & 0.00 \\
\hline 18 & 0.00 & e0.00 & 0.00 & 0.00 & 0.00 & 0.00 & 0.00 & 0.00 & 0.00 & 0.00 & 0.16 & 0.13 \\
\hline 19 & 0.00 & 0.00 & 0.00 & 0.00 & 0.00 & 0.00 & 0.00 & 0.00 & 0.00 & 0.03 & 0.04 & 0.60 \\
\hline 20 & 0.00 & 0.00 & 0.00 & 0.09 & 0.00 & 0.00 & 0.00 & 0.00 & 0.00 & 0.16 & 0.01 & 0.03 \\
\hline 21 & 0.00 & 0.00 & 0.00 & 0.00 & 0.08 & 0.00 & 0.00 & 0.00 & 0.00 & 0.04 & 0.01 & 0.00 \\
\hline 22 & 0.00 & 0.00 & 0.00 & 0.00 & 0.00 & 0.00 & 0.00 & 0.00 & 0.00 & 0.01 & 0.00 & 0.00 \\
\hline 23 & 0.00 & 0.00 & 0.00 & 0.00 & 0.68 & 0.00 & 0.01 & 0.00 & 0.00 & 0.24 & 0.00 & 0.00 \\
\hline 24 & 0.00 & 0.00 & 0.00 & 0.00 & 0.25 & 0.00 & 0.00 & 0.00 & 0.00 & 0.24 & 0.00 & 0.00 \\
\hline 25 & 0.00 & 0.00 & 0.00 & 0.05 & 0.00 & 0.00 & 0.00 & 0.00 & 0.00 & 0.16 & 0.00 & 0.00 \\
\hline 26 & 0.00 & 0.00 & 0.00 & 0.00 & 0.00 & 0.00 & 0.00 & 0.00 & 0.24 & 0.00 & 0.00 & 0.00 \\
\hline 27 & 0.00 & 0.00 & 0.00 & 0.00 & 0.00 & 0.00 & 0.00 & 0.00 & 0.00 & 0.66 & 0.00 & 0.00 \\
\hline 28 & 0.00 & 0.00 & 0.00 & 0.00 & 0.17 & 0.00 & 0.00 & 0.00 & 0.00 & 0.05 & 0.00 & 0.00 \\
\hline 29 & 0.00 & 0.00 & 0.00 & 0.00 & 0.00 & 0.00 & 0.00 & 0.00 & 0.45 & 0.00 & 0.00 & 0.22 \\
\hline 30 & 0.00 & 0.00 & 0.00 & 0.00 & --- & 0.00 & 0.00 & 0.00 & 0.00 & 0.00 & 0.00 & 0.01 \\
\hline 31 & 0.00 & --- & 0.00 & 0.00 & --- & 0.00 & --- & 0.00 & --- & 0.00 & 0.00 & --- \\
\hline TOTAL & 1.11 & 0.83 & 0.16 & 0.19 & 1.27 & 0.87 & 1.98 & 0.00 & 0.69 & 1.76 & 0.49 & 1.16 \\
\hline MAX & 0.75 & 0.57 & 0.13 & 0.09 & 0.68 & 0.65 & 1.10 & 0.00 & 0.45 & 0.66 & 0.16 & 0.60 \\
\hline MIN & 0.00 & 0.00 & 0.00 & 0.00 & 0.00 & 0.00 & 0.00 & 0.00 & 0.00 & 0.00 & 0.00 & 0.00 \\
\hline
\end{tabular}

CAL YR 2003 TOTAL 5.83 MAX 0.75 MIN 0.00 WTR YR 2004 TOTAL 10.51 MAX $1.10 \quad$ MIN 0.00 


\section{0, ORLANDO ROMERO RAIN GAGE IN ALBUQUERQUE, NEW MEXICO STATION ANALYSIS \\ WATER YEAR 2004}

Location.--35 $04^{\prime} 17^{\prime} \mathrm{N}, 106^{\circ} 36^{\prime} 33^{\prime \prime} \mathrm{W}$. The rain gage is located in southeast Albuquerque at a private residence, approximately 0.25 mile from the intersection of Carlisle Boulevard and Burton Street.

Equipment.--Onset Corporation HOBO Event data recorder and 7.9-inch-diameter tipping bucket. The bucket tips one time per 0.01 inch of rain, and the recorder stores data at 5-minute intervals. Rain gage is calibrated approximately every 2 years and was last calibrated in March 2003.

Record.--The rain gage gave a complete and satisfactory record for the entire water.

Period of Record.--March 2001 to present.

Remarks.--Record is good for the entire water year.

PRECIPITATION, TOTAL, INCHES, WATER YEAR OCTOBER 2003 TO SEPTEMBER 2004 DAILY SUM VALUES

\begin{tabular}{|c|c|c|c|c|c|c|c|c|c|c|c|c|}
\hline DAY & ОСт & NOV & $\mathrm{DEC}$ & JAN & FEB & MAR & APR & MAY & JUN & JUL & AUG & SEP \\
\hline 1 & 0.00 & 0.00 & 0.00 & 0.00 & 0.02 & 0.00 & 0.00 & 0.00 & 0.00 & 0.00 & 0.00 & 0.00 \\
\hline 2 & 0.00 & 0.00 & 0.00 & 0.00 & 0.00 & 0.13 & 0.57 & 0.00 & 0.00 & 0.00 & 0.12 & 0.00 \\
\hline 3 & 0.11 & 0.00 & 0.00 & 0.00 & 0.02 & 0.04 & 1.74 & 0.00 & 0.00 & 0.00 & 0.01 & 0.00 \\
\hline 4 & 0.01 & 0.00 & 0.00 & 0.00 & 0.02 & 0.71 & 0.10 & 0.00 & 0.02 & 0.00 & 0.00 & 0.12 \\
\hline 5 & 0.00 & 0.00 & 0.00 & 0.00 & 0.00 & 0.07 & 0.00 & 0.00 & 0.00 & 0.00 & 0.00 & 0.00 \\
\hline 6 & 0.00 & 0.00 & 0.00 & 0.00 & 0.00 & 0.00 & 0.00 & 0.00 & 0.07 & 0.00 & 0.00 & 0.00 \\
\hline 7 & 1.07 & 0.00 & 0.00 & 0.00 & 0.00 & 0.00 & 0.00 & 0.00 & 0.00 & 0.00 & 0.00 & 0.00 \\
\hline 8 & 0.24 & 0.00 & 0.00 & 0.00 & 0.00 & 0.00 & 0.38 & 0.00 & 0.00 & 0.00 & 0.00 & 0.00 \\
\hline 9 & 0.00 & 0.00 & 0.00 & 0.00 & 0.00 & 0.00 & 0.06 & 0.00 & 0.00 & 0.00 & 0.00 & 0.00 \\
\hline 10 & 0.22 & 0.00 & 0.00 & 0.00 & 0.00 & 0.00 & 0.20 & 0.00 & 0.00 & 0.00 & 0.11 & 0.00 \\
\hline 11 & 0.01 & 0.01 & 0.00 & 0.00 & 0.00 & 0.00 & 0.00 & 0.00 & 0.00 & 0.06 & 0.04 & 0.00 \\
\hline 12 & 0.00 & 0.51 & 0.16 & 0.00 & 0.00 & 0.00 & 0.00 & 0.00 & 0.00 & 0.31 & 0.00 & 0.00 \\
\hline 13 & 0.00 & 0.20 & 0.00 & 0.00 & 0.00 & 0.00 & 0.00 & 0.00 & 0.00 & 0.00 & 0.00 & 0.00 \\
\hline 14 & 0.00 & 0.00 & 0.00 & 0.00 & 0.00 & 0.00 & 0.00 & 0.00 & 0.00 & 0.00 & 0.00 & 0.00 \\
\hline 15 & 0.00 & 0.00 & 0.00 & 0.05 & 0.00 & 0.00 & 0.00 & 0.00 & 0.00 & 0.16 & 0.00 & 0.00 \\
\hline 16 & 0.00 & 0.05 & 0.00 & 0.02 & 0.00 & 0.00 & 0.00 & 0.00 & 0.00 & 0.00 & 0.00 & 0.00 \\
\hline 17 & 0.00 & 0.00 & 0.00 & 0.02 & 0.00 & 0.00 & 0.00 & 0.00 & 0.00 & 0.00 & 0.00 & 0.00 \\
\hline 18 & 0.00 & 0.00 & 0.00 & 0.00 & 0.00 & 0.00 & 0.00 & 0.00 & 0.00 & 0.05 & 0.00 & 0.08 \\
\hline 19 & 0.00 & 0.00 & 0.00 & 0.00 & 0.00 & 0.00 & 0.00 & 0.00 & 0.00 & 0.04 & 0.01 & 1.14 \\
\hline 20 & 0.00 & 0.00 & 0.00 & 0.08 & 0.00 & 0.00 & 0.00 & 0.00 & 0.00 & 0.07 & 0.00 & 0.04 \\
\hline 21 & 0.00 & 0.00 & 0.00 & 0.00 & 0.09 & 0.00 & 0.00 & 0.00 & 0.00 & 0.00 & 0.00 & 0.00 \\
\hline 22 & 0.00 & 0.00 & 0.00 & 0.00 & 0.27 & 0.00 & 0.00 & 0.00 & 0.01 & 0.50 & 0.00 & 0.00 \\
\hline 23 & 0.00 & 0.00 & 0.00 & 0.00 & 1.09 & 0.11 & 0.00 & 0.00 & 0.00 & 2.60 & 0.00 & 0.00 \\
\hline 24 & 0.00 & 0.00 & 0.00 & 0.00 & 1.84 & 0.00 & 0.00 & 0.00 & 0.00 & 0.21 & 0.00 & 0.00 \\
\hline 25 & 0.00 & 0.00 & 0.00 & 0.02 & 0.04 & 0.00 & 0.00 & 0.00 & 0.00 & 0.38 & 0.00 & 0.00 \\
\hline 26 & 0.00 & 0.00 & 0.00 & 0.00 & 0.00 & 0.00 & 0.00 & 0.00 & 0.00 & 0.00 & 0.00 & 0.00 \\
\hline 27 & 0.00 & 0.00 & 0.00 & 0.00 & 0.00 & 0.00 & 0.00 & 0.00 & 0.00 & 0.12 & 0.00 & 0.00 \\
\hline 28 & 0.00 & 0.00 & 0.00 & 0.00 & 0.15 & 0.00 & 0.00 & 0.00 & 0.18 & 0.04 & 0.00 & 0.00 \\
\hline 29 & 0.00 & 0.00 & 0.00 & 0.00 & 0.00 & 0.00 & 0.00 & 0.00 & 0.89 & 0.00 & 0.00 & 0.00 \\
\hline 30 & 0.00 & 0.00 & 0.00 & 0.00 & --- & 0.00 & 0.00 & 0.00 & 0.00 & 0.00 & 0.00 & 0.08 \\
\hline 31 & 0.00 & --- & 0.00 & 0.00 & --- & 0.00 & --- & 0.00 & --- & 0.00 & 0.00 & --- \\
\hline TOTAL & 1.66 & 0.77 & 0.16 & 0.19 & 3.54 & 1.06 & 3.05 & 0.00 & 1.17 & 4.54 & 0.29 & 1.46 \\
\hline MAX & 1.07 & 0.51 & 0.16 & 0.08 & 1.84 & 0.71 & 1.74 & 0.00 & 0.89 & 2.60 & 0.12 & 1.14 \\
\hline MIN & 0.00 & 0.00 & 0.00 & 0.00 & 0.00 & 0.00 & 0.00 & 0.00 & 0.00 & 0.00 & 0.00 & 0.00 \\
\hline
\end{tabular}

CAL YR 2003 TOTAL 7.18 MAX 1.07 MIN 0.00

WTR YR 2004 TOTAL 17.89 MAX 2.60 MIN 0.00 


\section{0, PETROGLYPHS PARK RAIN GAGE AT ALBUQUERQUE, NEW MEXICO STATION ANALYSIS \\ WATER YEAR 2004}

Location.--35 $09^{\prime} 39^{\prime \prime} \mathrm{N}, 106^{\circ} 43^{\prime} 10^{\prime \prime} \mathrm{W}$. The rain gage is located in far northwest Albuquerque at the Petroglyphs National Park Visitor Center.

Equipment.--Onset Corporation HOBO Event data recorder and 7.9-inch-diameter tipping bucket. The bucket tips one time per 0.01 inch of rain, and the recorder stores data at 5 -minute intervals. Rain gage is calibrated approximately every 2 years and was last calibrated in March 2003.

Record.--The rain gage gave a complete and satisfactory record for the entire water year.

Period of Record.--January 1995 to present.

Remarks.--Record is good for the entire water year.

PRECIPITATION, TOTAL, INCHES, WATER YEAR OCTOBER 2003 TO SEPTEMBER 2004 DAILY SUM VALUES

\begin{tabular}{|c|c|c|c|c|c|c|c|c|c|c|c|c|}
\hline DAY & ОСт & Nov & $\mathrm{DEC}$ & JAN & $\mathrm{FEB}$ & MAR & APR & MAY & JUN & JUL & AUG & SEP \\
\hline 1 & 0.00 & 0.00 & 0.00 & 0.00 & 0.00 & 0.00 & 0.00 & 0.00 & 0.00 & 0.00 & 0.00 & 0.00 \\
\hline 2 & 0.00 & 0.00 & 0.00 & 0.00 & 0.00 & 0.20 & 0.61 & 0.00 & 0.00 & 0.00 & 0.07 & 0.00 \\
\hline 3 & 0.08 & 0.00 & 0.00 & 0.00 & 0.01 & 0.02 & 1.42 & 0.00 & 0.00 & 0.00 & 0.00 & 0.05 \\
\hline 4 & 0.02 & 0.00 & 0.00 & 0.00 & 0.00 & 0.74 & 0.19 & 0.00 & 0.00 & 0.00 & 0.04 & 0.08 \\
\hline 5 & 0.00 & 0.00 & 0.00 & 0.00 & 0.00 & 0.01 & 0.00 & 0.00 & 0.00 & 0.00 & 0.05 & 0.00 \\
\hline 6 & 0.00 & 0.00 & 0.00 & 0.00 & 0.00 & 0.00 & 0.00 & 0.00 & 0.00 & 0.00 & 0.00 & 0.00 \\
\hline 7 & 0.70 & 0.00 & 0.00 & 0.00 & 0.00 & 0.00 & 0.00 & 0.00 & 0.00 & 0.00 & 0.00 & 0.00 \\
\hline 8 & 0.23 & 0.00 & 0.03 & 0.00 & 0.00 & 0.00 & 0.21 & 0.00 & 0.00 & 0.00 & 0.00 & 0.00 \\
\hline 9 & 0.00 & 0.00 & 0.00 & 0.00 & 0.00 & 0.00 & 0.05 & 0.00 & 0.00 & 0.00 & 0.00 & 0.00 \\
\hline 10 & 0.00 & 0.00 & 0.00 & 0.00 & 0.00 & 0.00 & 0.33 & 0.00 & 0.00 & 0.00 & 0.00 & 0.00 \\
\hline 11 & 0.00 & 0.00 & 0.00 & 0.00 & 0.00 & 0.00 & 0.00 & 0.00 & 0.00 & 0.00 & 0.08 & 0.00 \\
\hline 12 & 0.00 & 0.56 & 0.10 & 0.00 & 0.00 & 0.00 & 0.00 & 0.00 & 0.00 & 0.02 & 0.00 & 0.00 \\
\hline 13 & 0.00 & 0.16 & 0.00 & 0.00 & 0.00 & 0.00 & 0.00 & 0.00 & 0.00 & 0.00 & 0.05 & 0.00 \\
\hline 14 & 0.00 & 0.00 & 0.00 & 0.00 & 0.00 & 0.00 & 0.00 & 0.00 & 0.00 & 0.00 & 0.00 & 0.00 \\
\hline 15 & 0.00 & 0.00 & 0.00 & 0.05 & 0.00 & 0.00 & 0.00 & 0.00 & 0.00 & 0.00 & 0.00 & 0.00 \\
\hline 16 & 0.00 & 0.00 & 0.00 & 0.00 & 0.00 & 0.00 & 0.00 & 0.00 & 0.00 & 0.00 & 0.00 & 0.00 \\
\hline 17 & 0.00 & 0.00 & 0.00 & 0.00 & 0.00 & 0.00 & 0.00 & 0.00 & 0.00 & 0.00 & 0.00 & 0.00 \\
\hline 18 & 0.00 & 0.00 & 0.00 & 0.00 & 0.00 & 0.00 & 0.00 & 0.00 & 0.00 & 0.00 & 0.03 & 0.15 \\
\hline 19 & 0.00 & 0.00 & 0.00 & 0.00 & 0.00 & 0.00 & 0.00 & 0.00 & 0.00 & 0.12 & 0.01 & 0.40 \\
\hline 20 & 0.00 & 0.00 & 0.00 & 0.06 & 0.00 & 0.00 & 0.00 & 0.00 & 0.00 & 0.09 & 0.01 & 0.00 \\
\hline 21 & 0.00 & 0.00 & 0.00 & 0.00 & 0.07 & 0.00 & 0.00 & 0.00 & 0.00 & 0.00 & 0.01 & 0.00 \\
\hline 22 & 0.00 & 0.00 & 0.00 & 0.00 & 0.00 & 0.00 & 0.00 & 0.00 & 0.00 & 0.38 & 0.00 & 0.00 \\
\hline 23 & 0.00 & 0.00 & 0.00 & 0.00 & 0.72 & 0.01 & 0.01 & 0.00 & 0.00 & 0.03 & 0.00 & 0.00 \\
\hline 24 & 0.00 & 0.00 & 0.00 & 0.00 & 0.36 & 0.00 & 0.01 & 0.00 & 0.00 & 0.47 & 0.00 & 0.00 \\
\hline 25 & 0.00 & 0.00 & 0.00 & 0.01 & 0.00 & 0.00 & 0.00 & 0.00 & 0.00 & 0.17 & 0.00 & 0.00 \\
\hline 26 & 0.00 & 0.00 & 0.00 & 0.00 & 0.00 & 0.00 & 0.00 & 0.00 & 0.00 & 0.00 & 0.00 & 0.00 \\
\hline 27 & 0.00 & 0.00 & 0.00 & 0.00 & 0.00 & 0.00 & 0.00 & 0.00 & 0.00 & 0.10 & 0.00 & 0.00 \\
\hline 28 & 0.00 & 0.00 & 0.00 & 0.00 & 0.12 & 0.00 & 0.00 & 0.00 & 0.00 & 0.00 & 0.00 & 0.00 \\
\hline 29 & 0.00 & 0.00 & 0.00 & 0.00 & 0.01 & 0.00 & 0.00 & 0.00 & 0.57 & 0.00 & 0.00 & 0.54 \\
\hline 30 & 0.00 & 0.00 & 0.00 & 0.00 & --- & 0.00 & 0.00 & 0.00 & 0.00 & 0.00 & 0.00 & 0.01 \\
\hline 31 & 0.00 & --- & 0.00 & 0.00 & --- & 0.00 & --- & 0.00 & --- & 0.00 & 0.00 & --- \\
\hline TOTAL & 1.03 & 0.72 & 0.13 & 0.12 & 1.29 & 0.98 & 2.83 & 0.00 & 0.57 & 1.38 & 0.35 & 1.23 \\
\hline MAX & 0.70 & 0.56 & 0.10 & 0.06 & 0.72 & 0.74 & 1.42 & 0.00 & 0.57 & 0.47 & 0.08 & 0.54 \\
\hline MIN & 0.00 & 0.00 & 0.00 & 0.00 & 0.00 & 0.00 & 0.00 & 0.00 & 0.00 & 0.00 & 0.00 & 0.00 \\
\hline
\end{tabular}




\section{0, RIO RANCHO WELL \#13 RAIN GAGE, RIO RANCHO, NEW MEXICO STATION ANALYSIS \\ WATER YEAR 2004}

Location.--35'16’31'N, 106 48'12'W. The rain gage is located at a public supply well in Rio Rancho, approximately 6 miles northwest of the Albuquerque City Limit. This property is located at the intersection of Northern Boulevard and Encino Street.

Equipment.--Onset Corporation HOBO Event data recorder and 6.3-inch-diameter tipping bucket. The bucket tips one time per 0.01 inch of rain, and the recorder stores data at 5-minute intervals. Rain gage is calibrated approximately every 2 years and was last calibrated in July 2004.

Record.--The rain gage gave a complete and satisfactory record for the period of record.

Period of Record.-July 22, 2004 to present.

Remarks.--Record is good for the entire period of record. This is the first year of record for the rain gage.

PRECIPITATION, TOTAL, INCHES, WATER YEAR OCTOBER 2003 TO SEPTEMBER 2004 DAILY SUM VALUES

\begin{tabular}{|c|c|c|c|c|c|c|c|c|c|c|c|c|}
\hline DAY & ОСт & NOV & DEC & JAN & FEB & MAR & APR & MAY & JUN & JUL & AUG & SEP \\
\hline 1 & --- & --- & --- & --- & --- & --- & --- & --- & --- & --- & 0.03 & 0.00 \\
\hline 2 & --- & --- & --- & --- & --- & --- & --- & --- & --- & --- & 0.06 & 0.00 \\
\hline 3 & --- & --- & --- & --- & --- & --- & --- & --- & --- & --- & 0.01 & 0.00 \\
\hline 4 & --- & --- & --- & --- & --- & --- & --- & --- & --- & --- & 0.25 & 0.28 \\
\hline 5 & --- & --- & --- & --- & --- & --- & --- & --- & --- & --- & 0.03 & 0.00 \\
\hline 6 & --- & --- & --- & --- & --- & --- & --- & --- & --- & --- & 0.00 & 0.00 \\
\hline 7 & --- & --- & --- & --- & --- & --- & --- & --- & --- & --- & 0.00 & 0.00 \\
\hline 8 & --- & --- & --- & --- & --- & --- & --- & --- & --- & --- & 0.50 & 0.00 \\
\hline 9 & --- & --- & --- & --- & --- & --- & --- & --- & --- & --- & 0.00 & 0.00 \\
\hline 10 & --- & --- & --- & --- & --- & --- & --- & --- & --- & --- & 0.31 & 0.00 \\
\hline 11 & --- & --- & --- & --- & --- & --- & --- & --- & --- & --- & 0.00 & 0.00 \\
\hline 12 & --- & --- & --- & --- & --- & --- & --- & --- & --- & --- & 0.03 & 0.00 \\
\hline 13 & --- & --- & --- & --- & --- & --- & --- & --- & --- & --- & 0.00 & 0.00 \\
\hline 14 & --- & --- & --- & --- & --- & --- & --- & --- & --- & --- & 0.00 & 0.00 \\
\hline 15 & --- & --- & --- & --- & --- & --- & --- & --- & --- & --- & 0.00 & 0.00 \\
\hline 16 & --- & --- & --- & --- & --- & --- & --- & --- & --- & --- & 0.00 & 0.00 \\
\hline 17 & --- & --- & --- & --- & --- & --- & --- & --- & --- & --- & 0.00 & 0.00 \\
\hline 18 & --- & --- & --- & --- & --- & --- & --- & --- & --- & --- & 0.00 & 0.22 \\
\hline 19 & --- & --- & --- & --- & --- & --- & --- & --- & --- & --- & 0.02 & 0.41 \\
\hline 20 & --- & --- & --- & --- & --- & --- & --- & --- & --- & --- & 0.08 & 0.00 \\
\hline 21 & --- & --- & --- & --- & --- & --- & --- & --- & --- & --- & 0.00 & 0.00 \\
\hline 22 & --- & --- & --- & --- & --- & --- & --- & --- & --- & --- & 0.00 & 0.00 \\
\hline 23 & --- & --- & --- & --- & --- & --- & --- & --- & --- & 0.14 & 0.00 & 0.00 \\
\hline 24 & --- & --- & --- & --- & --- & --- & --- & --- & --- & 0.33 & 0.00 & 0.00 \\
\hline 25 & --- & --- & --- & --- & --- & --- & --- & --- & --- & 0.13 & 0.02 & 0.00 \\
\hline 26 & --- & --- & --- & --- & --- & --- & --- & --- & --- & 0.00 & 0.00 & 0.00 \\
\hline 27 & --- & --- & --- & --- & --- & --- & --- & --- & --- & 0.20 & 0.00 & 0.00 \\
\hline 28 & --- & --- & --- & --- & --- & --- & --- & --- & --- & 0.01 & 0.00 & 0.00 \\
\hline 29 & --- & --- & --- & --- & --- & --- & --- & --- & --- & 0.19 & 0.00 & 0.24 \\
\hline 30 & --- & --- & --- & --- & --- & --- & --- & --- & --- & 0.11 & 0.00 & 0.00 \\
\hline 31 & --- & --- & --- & --- & --- & --- & --- & --- & --- & 0.04 & 0.00 & --- \\
\hline TOTAL & --- & --- & --- & --- & --- & --- & --- & --- & --- & 1.15 & 1.34 & 1.15 \\
\hline
\end{tabular}




\section{8, SOUTH FORK HAHN ARROYO RAIN GAGE IN ALBUQUERQUE, NEW MEXICO STATION ANALYSIS \\ WATER YEAR 2004}

Location.--35 $07^{\prime} 16^{\prime \prime} \mathrm{N}, 106^{\circ} 34^{\prime} 04^{\prime \prime} \mathrm{W}$. The rain gage is located in northeast Albuquerque at the surface-water gage, between Comanche and Candelaria Roads on Louisiana Boulevard.

Equipment.--7.9-inch-diameter tipping bucket connected to a surface-water data recorder or Onset Corporation HOBO Event data recorder. The bucket tips one time per 0.01 inch of rain, and the recorder stores data at 5minute intervals. Rain gage is calibrated approximately every 2 years and was last calibrated in March 2003.

Record.--The rain gage gave a complete and satisfactory record for the water year except for November 22 and February 12. Although this rain gage recorded substantial rain on these days, no precipitation or streamflow was recorded at other gages in the metropolitan area. For this reason, the record for these days should be considered suspect.

Period of Record.--October 1984 to present.

Remarks.--Record is good for the entire water year except for November 22 and February 12; record for these days is poor.

PRECIPITATION, TOTAL, INCHES, WATER YEAR OCTOBER 2003 TO SEPTEMBER 2004 DAILY SUM VALUES

\begin{tabular}{|c|c|c|c|c|c|c|c|c|c|c|c|c|}
\hline DAY & ОСт & NOV & DEC & JAN & FEB & MAR & APR & MAY & JUN & JUL & AUG & SEP \\
\hline 1 & 0.00 & 0.00 & 0.00 & 0.00 & 0.06 & 0.00 & 0.00 & 0.00 & 0.00 & 0.00 & 0.00 & 0.00 \\
\hline 2 & 0.00 & 0.00 & 0.00 & 0.00 & 0.00 & 0.10 & 0.28 & 0.00 & 0.00 & 0.00 & 0.21 & 0.00 \\
\hline 3 & 0.07 & 0.00 & 0.00 & 0.00 & 0.00 & 0.00 & 0.95 & 0.00 & 0.43 & 0.00 & 0.00 & 0.00 \\
\hline 4 & 0.03 & 0.00 & 0.00 & 0.00 & 0.05 & 0.74 & 0.10 & 0.00 & 0.00 & 0.00 & 0.25 & 0.09 \\
\hline 5 & 0.00 & 0.00 & 0.00 & 0.00 & 0.00 & 0.09 & 0.00 & 0.00 & 0.00 & 0.00 & 0.00 & 0.01 \\
\hline 6 & 0.00 & 0.00 & 0.00 & 0.00 & 0.00 & 0.00 & 0.05 & 0.00 & 0.00 & 0.00 & 0.06 & 0.00 \\
\hline 7 & 0.76 & 0.00 & 0.00 & 0.00 & 0.00 & 0.00 & 0.00 & 0.00 & 0.00 & 0.00 & 0.00 & 0.00 \\
\hline 8 & 0.21 & 0.00 & 0.00 & 0.00 & 0.00 & 0.00 & 0.28 & 0.00 & 0.00 & 0.00 & 0.00 & 0.00 \\
\hline 9 & 0.00 & 0.00 & 0.00 & 0.00 & 0.00 & 0.00 & 0.06 & 0.00 & 0.00 & 0.00 & 0.00 & 0.00 \\
\hline 10 & 0.10 & 0.00 & 0.00 & 0.00 & 0.00 & 0.00 & 0.25 & 0.00 & 0.00 & 0.00 & 0.26 & 0.00 \\
\hline 11 & 0.01 & 0.00 & 0.00 & 0.00 & 0.07 & 0.00 & 0.00 & 0.00 & 0.00 & 0.23 & 0.00 & 0.00 \\
\hline 12 & 0.00 & 0.60 & 0.12 & 0.00 & 0.20 & 0.00 & 0.00 & 0.00 & 0.00 & 0.95 & 0.00 & 0.00 \\
\hline 13 & 0.00 & 0.23 & 0.00 & 0.00 & 0.00 & 0.00 & 0.00 & 0.00 & 0.00 & 0.00 & 0.00 & 0.00 \\
\hline 14 & 0.00 & 0.00 & 0.00 & 0.00 & 0.00 & 0.00 & 0.00 & 0.00 & 0.00 & 0.06 & 0.00 & 0.00 \\
\hline 15 & 0.00 & 0.00 & 0.00 & 0.01 & 0.00 & 0.00 & 0.00 & 0.00 & 0.00 & 0.21 & 0.00 & 0.00 \\
\hline 16 & 0.00 & 0.04 & 0.00 & 0.02 & 0.00 & 0.00 & 0.00 & 0.00 & 0.00 & 0.00 & 0.00 & 0.00 \\
\hline 17 & 0.00 & 0.01 & 0.00 & 0.00 & 0.00 & 0.00 & 0.01 & 0.00 & 0.00 & 0.00 & 0.00 & 0.00 \\
\hline 18 & 0.00 & 0.00 & 0.00 & 0.00 & 0.00 & 0.00 & 0.00 & 0.00 & 0.00 & 0.01 & 0.00 & 0.06 \\
\hline 19 & 0.00 & 0.00 & 0.00 & 0.00 & 0.00 & 0.00 & 0.00 & 0.00 & 0.00 & 0.00 & 0.01 & 0.99 \\
\hline 20 & 0.00 & 0.00 & 0.00 & 0.08 & 0.00 & 0.00 & 0.00 & 0.00 & 0.00 & 0.12 & 0.00 & 0.04 \\
\hline 21 & 0.00 & 0.00 & 0.00 & 0.00 & 0.07 & 0.00 & 0.00 & 0.00 & 0.00 & 0.01 & 0.01 & 0.00 \\
\hline 22 & 0.00 & 0.52 & 0.00 & 0.00 & 0.00 & 0.00 & 0.05 & 0.00 & 0.00 & 0.00 & 0.00 & 0.00 \\
\hline 23 & 0.00 & 0.01 & 0.00 & 0.00 & 0.84 & 0.02 & 0.00 & 0.00 & 0.00 & 0.95 & 0.00 & 0.00 \\
\hline 24 & 0.00 & 0.00 & 0.00 & 0.00 & 0.45 & 0.00 & 0.00 & 0.00 & 0.00 & 0.16 & 0.00 & 0.00 \\
\hline 25 & 0.00 & 0.00 & 0.00 & 0.03 & 0.00 & 0.00 & 0.00 & 0.00 & 0.00 & 0.28 & 0.00 & 0.00 \\
\hline 26 & 0.00 & 0.00 & 0.00 & 0.00 & 0.00 & 0.00 & 0.00 & 0.00 & 0.27 & 0.00 & 0.00 & 0.00 \\
\hline 27 & 0.00 & 0.00 & 0.00 & 0.00 & 0.00 & 0.00 & 0.00 & 0.00 & 0.00 & 0.75 & 0.00 & 0.00 \\
\hline 28 & 0.00 & 0.00 & 0.00 & 0.00 & 0.12 & 0.00 & 0.00 & 0.00 & 0.01 & 0.03 & 0.00 & 0.00 \\
\hline 29 & 0.00 & 0.00 & 0.00 & 0.00 & 0.04 & 0.00 & 0.00 & 0.00 & 0.47 & 0.00 & 0.00 & 0.00 \\
\hline 30 & 0.00 & 0.00 & 0.00 & 0.00 & --- & 0.00 & 0.00 & 0.00 & 0.00 & 0.00 & 0.00 & 0.00 \\
\hline 31 & 0.00 & --- & 0.00 & 0.00 & --- & 0.00 & --- & 0.00 & --- & 0.00 & 0.00 & --- \\
\hline TOTAL & 1.18 & 1.41 & 0.12 & 0.14 & 1.90 & 0.95 & 2.03 & 0.00 & 1.18 & 3.76 & 0.80 & 1.19 \\
\hline MAX & 0.76 & 0.60 & 0.12 & 0.08 & 0.84 & 0.74 & 0.95 & 0.00 & 0.47 & 0.95 & 0.26 & 0.99 \\
\hline MIN & 0.00 & 0.00 & 0.00 & 0.00 & 0.00 & 0.00 & 0.00 & 0.00 & 0.00 & 0.00 & 0.00 & 0.00 \\
\hline
\end{tabular}

CAL YR 2003 TOTAL 7.32 MAX $0.76 \quad$ MIN 0.00

WTR YR 2004 TOTAL 14.66 MAX 0.99 MIN 0.00 


\section{0, SAN JOSE DRAIN RAIN GAGE AT ALBUQUERQUE, NEW MEXICO STATION ANALYSIS \\ WATER YEAR 2004}

Location.--35 $02^{\prime} 56^{\prime} \mathrm{N}, 106^{\circ} 38^{\prime} 55^{\prime} \mathrm{W}$. The rain gage is located in southwest Albuquerque at the surface-water gage, just west of the intersection of Broadway Boulevard and Woodward Street.

Equipment.--8.0-inch-diameter tipping bucket connected to a surface-water data recorder. The bucket tips one time per 0.01 inch of rain, and the recorder stores data at 5-minute intervals. Rain gage is calibrated approximately every 2 years and was last calibrated in March 2003.

Record.--The rain gage gave a complete and satisfactory record for the water year except for March 30 to April 4; during this period the data recorder malfunctioned. The estimated daily totals for these days are based on both totals observed during gage inspections and the daily totals from the Bernalillo County Building and Wastewater Treatment Plant rain gages.

Period of Record.--June 1998 to present.

Remarks.--Record is good for the entire water year including estimated days.

PRECIPITATION, TOTAL, INCHES, WATER YEAR OCTOBER 2003 TO SEPTEMBER 2004 DAILY SUM VALUES

\begin{tabular}{|c|c|c|c|c|c|c|c|c|c|c|c|c|}
\hline DAY & OCT & NOV & $\mathrm{DEC}$ & JAN & FEB & MAR & APR & MAY & JUN & JUL & AUG & SEP \\
\hline 1 & 0.00 & 0.00 & 0.00 & 0.00 & 0.01 & 0.00 & e0.00 & 0.00 & 0.00 & 0.00 & 0.00 & 0.00 \\
\hline 2 & 0.00 & 0.00 & 0.00 & 0.00 & 0.00 & 0.10 & $\mathrm{e} 0.61$ & 0.00 & 0.00 & 0.00 & 0.05 & 0.00 \\
\hline 3 & 0.05 & 0.00 & 0.00 & 0.00 & 0.01 & 0.00 & e2.00 & 0.00 & 0.00 & 0.00 & 0.01 & 0.00 \\
\hline 4 & 0.01 & 0.00 & 0.00 & 0.00 & 0.00 & 0.70 & e0.14 & 0.00 & 0.00 & 0.00 & 0.00 & 0.08 \\
\hline 5 & 0.00 & 0.00 & 0.00 & 0.00 & 0.00 & 0.02 & 0.00 & 0.00 & 0.00 & 0.00 & 0.00 & 0.00 \\
\hline 6 & 0.00 & 0.00 & 0.00 & 0.00 & 0.00 & 0.00 & 0.00 & 0.00 & 0.00 & 0.00 & 0.00 & 0.00 \\
\hline 7 & 0.45 & 0.00 & 0.00 & 0.00 & 0.00 & 0.00 & 0.02 & 0.00 & 0.00 & 0.00 & 0.00 & 0.00 \\
\hline 8 & 0.10 & 0.00 & 0.00 & 0.00 & 0.00 & 0.00 & 0.40 & 0.00 & 0.00 & 0.00 & 0.00 & 0.00 \\
\hline 9 & 0.00 & 0.00 & 0.00 & 0.00 & 0.00 & 0.00 & 0.00 & 0.00 & 0.00 & 0.00 & 0.00 & 0.00 \\
\hline 10 & 0.13 & 0.00 & 0.00 & 0.00 & 0.00 & 0.00 & 0.22 & 0.00 & 0.00 & 0.00 & 0.09 & 0.00 \\
\hline 11 & 0.00 & 0.00 & 0.00 & 0.00 & 0.00 & 0.00 & 0.00 & 0.00 & 0.00 & 0.00 & 0.01 & 0.00 \\
\hline 12 & 0.00 & 0.15 & 0.18 & 0.00 & 0.00 & 0.00 & 0.00 & 0.00 & 0.00 & 0.39 & 0.00 & 0.00 \\
\hline 13 & 0.00 & 0.03 & 0.00 & 0.00 & 0.00 & 0.00 & 0.00 & 0.00 & 0.00 & 0.00 & 0.00 & 0.00 \\
\hline 14 & 0.00 & 0.00 & 0.00 & 0.00 & 0.00 & 0.00 & 0.00 & 0.00 & 0.00 & 0.00 & 0.00 & 0.00 \\
\hline 15 & 0.00 & 0.00 & 0.00 & 0.05 & 0.00 & 0.00 & 0.00 & 0.00 & 0.00 & 0.18 & 0.20 & 0.00 \\
\hline 16 & 0.00 & 0.02 & 0.00 & 0.02 & 0.00 & 0.00 & 0.00 & 0.00 & 0.00 & 0.00 & 0.00 & 0.00 \\
\hline 17 & 0.00 & 0.00 & 0.00 & 0.00 & 0.00 & 0.00 & 0.03 & 0.00 & 0.00 & 0.00 & 0.00 & 0.00 \\
\hline 18 & 0.00 & 0.01 & 0.00 & 0.00 & 0.00 & 0.00 & 0.00 & 0.00 & 0.00 & 0.20 & 0.03 & 0.12 \\
\hline 19 & 0.00 & 0.00 & 0.00 & 0.00 & 0.00 & 0.00 & 0.00 & 0.00 & 0.00 & 0.00 & 0.02 & 0.85 \\
\hline 20 & 0.00 & 0.00 & 0.00 & 0.08 & 0.00 & 0.00 & 0.00 & 0.00 & 0.00 & 0.07 & 0.00 & 0.03 \\
\hline 21 & 0.00 & 0.00 & 0.00 & 0.01 & 0.10 & 0.00 & 0.00 & 0.00 & 0.00 & 0.01 & 0.00 & 0.00 \\
\hline 22 & 0.00 & 0.00 & 0.00 & 0.00 & 0.00 & 0.00 & 0.00 & 0.00 & 0.00 & 0.34 & 0.00 & 0.00 \\
\hline 23 & 0.00 & 0.00 & 0.00 & 0.00 & 0.75 & 0.12 & 0.00 & 0.00 & 0.00 & 0.68 & 0.00 & 0.00 \\
\hline 24 & 0.00 & 0.00 & 0.00 & 0.00 & 0.27 & 0.00 & 0.00 & 0.00 & 0.00 & 0.14 & 0.00 & 0.00 \\
\hline 25 & 0.00 & 0.00 & 0.00 & 0.00 & 0.00 & 0.00 & 0.00 & 0.00 & 0.00 & 0.33 & 0.00 & 0.00 \\
\hline 26 & 0.00 & 0.00 & 0.00 & 0.00 & 0.00 & 0.00 & 0.00 & 0.00 & 0.00 & 0.00 & 0.00 & 0.00 \\
\hline 27 & 0.00 & 0.00 & 0.00 & 0.00 & 0.00 & 0.00 & 0.00 & 0.00 & 0.00 & 0.04 & 0.00 & 0.00 \\
\hline 28 & 0.00 & 0.00 & 0.00 & 0.00 & 0.12 & 0.00 & 0.00 & 0.00 & 0.00 & 0.00 & 0.00 & 0.00 \\
\hline 29 & 0.00 & 0.00 & 0.00 & 0.00 & 0.00 & 0.00 & 0.00 & 0.00 & 0.49 & 0.00 & 0.00 & 0.10 \\
\hline 30 & 0.00 & 0.00 & 0.00 & 0.00 & --- & e0.00 & 0.00 & 0.00 & 0.00 & 0.00 & 0.01 & 0.01 \\
\hline 31 & 0.00 & --- & 0.00 & 0.00 & --- & e0.00 & --- & 0.00 & --- & 0.00 & 0.00 & --- \\
\hline TOTAL & 0.74 & 0.21 & 0.18 & 0.16 & 1.26 & 0.94 & 3.42 & 0.00 & 0.49 & 2.38 & 0.42 & 1.19 \\
\hline MAX & 0.45 & 0.15 & 0.18 & 0.08 & 0.75 & 0.70 & 2.00 & 0.00 & 0.49 & 0.68 & 0.20 & 0.85 \\
\hline MIN & 0.00 & 0.00 & 0.00 & 0.00 & 0.00 & 0.00 & 0.00 & 0.00 & 0.00 & 0.00 & 0.00 & 0.00 \\
\hline
\end{tabular}

CAL YR 2003 TOTAL 5.18 MAX 0.48 MIN 0.00

WTR YR 2004 TOTAL 11.39 MAX 2.00 MIN 0.00 


\section{0, SWINBURN DAM RAIN GAGE AT PARADISE HILLS, NEW MEXICO STATION ANALYSIS \\ WATER YEAR 2004}

Location.--35 $12^{\circ} 16^{\prime \prime} \mathrm{N}, 106^{\circ} 42^{\prime} 13^{\prime \prime} \mathrm{W}$. The rain gage is located in far northwest Albuquerque just south of the Swinburn detention dam.

Equipment.--Onset Corporation HOBO Event data recorder and 6.5-inch-diameter tipping bucket. The bucket tips one time per 0.01 inch of rain, and the recorder stores data at 5 -minute intervals. Rain gage is calibrated approximately every 2 years and was last calibrated in March 2003.

Record.--The rain gage gave a complete and satisfactory record for the water year except from October 11 to 17. During this period the data recorder lost power. Estimated daily totals for this period are the daily totals from the TM Kelly rain gage.

Period of Record.--August 2000 to present.

Remarks.--Record is good for the water year, including days estimated at zero; other estimates are poor. PRECIPITATION, TOTAL, INCHES, WATER YEAR OCTOBER 2003 TO SEPTEMBER 2004 DAILY SUM VALUES

\begin{tabular}{|c|c|c|c|c|c|c|c|c|c|c|c|c|}
\hline DAY & OCT & NOV & DEC & JAN & FEB & MAR & APR & MAY & JUN & JUL & AUG & SEP \\
\hline 1 & 0.00 & 0.01 & 0.00 & 0.00 & 0.00 & 0.00 & 0.00 & 0.00 & 0.00 & 0.00 & 0.00 & 0.00 \\
\hline 2 & 0.00 & 0.00 & 0.00 & 0.00 & 0.00 & 0.28 & 0.87 & 0.00 & 0.00 & 0.00 & 0.31 & 0.00 \\
\hline 3 & 0.11 & 0.00 & 0.00 & 0.00 & 0.02 & 0.03 & 1.86 & 0.00 & 0.00 & 0.00 & 0.01 & 0.04 \\
\hline 4 & 0.03 & 0.00 & 0.00 & 0.00 & 0.00 & 0.81 & 0.26 & 0.00 & 0.00 & 0.00 & 0.03 & 0.09 \\
\hline 5 & 0.00 & 0.00 & 0.00 & 0.00 & 0.00 & 0.02 & 0.00 & 0.00 & 0.00 & 0.00 & 0.04 & 0.01 \\
\hline 6 & 0.00 & 0.00 & 0.00 & 0.00 & 0.00 & 0.00 & 0.01 & 0.00 & 0.00 & 0.00 & 0.00 & 0.00 \\
\hline 7 & 0.74 & 0.00 & 0.00 & 0.00 & 0.00 & 0.00 & 0.01 & 0.00 & 0.00 & 0.00 & 0.00 & 0.00 \\
\hline 8 & 0.23 & 0.00 & 0.04 & 0.00 & 0.00 & 0.00 & 0.30 & 0.00 & 0.00 & 0.00 & 0.00 & 0.00 \\
\hline 9 & 0.00 & 0.00 & 0.00 & 0.00 & 0.00 & 0.00 & 0.07 & 0.00 & 0.00 & 0.00 & 0.00 & 0.00 \\
\hline 10 & 0.01 & 0.01 & 0.00 & 0.00 & 0.00 & 0.00 & 0.47 & 0.00 & 0.00 & 0.00 & 0.00 & 0.00 \\
\hline 11 & e0.01 & 0.00 & 0.00 & 0.00 & 0.00 & 0.00 & 0.02 & 0.00 & 0.00 & 0.00 & 0.00 & 0.00 \\
\hline 12 & e0.00 & 0.61 & 0.12 & 0.00 & 0.01 & 0.00 & 0.01 & 0.00 & 0.00 & 0.00 & 0.00 & 0.00 \\
\hline 13 & e0.00 & 0.21 & 0.00 & 0.00 & 0.00 & 0.00 & 0.00 & 0.00 & 0.00 & 0.00 & 0.07 & 0.00 \\
\hline 14 & e0.00 & 0.00 & 0.00 & 0.00 & 0.00 & 0.00 & 0.00 & 0.00 & 0.00 & 0.00 & 0.00 & 0.00 \\
\hline 15 & e0.00 & 0.01 & 0.01 & 0.06 & 0.00 & 0.00 & 0.00 & 0.00 & 0.00 & 0.00 & 0.00 & 0.00 \\
\hline 16 & e0.00 & 0.02 & 0.00 & 0.01 & 0.00 & 0.00 & 0.00 & 0.00 & 0.00 & 0.00 & 0.00 & 0.00 \\
\hline 17 & $\mathrm{e} 0.00$ & 0.01 & 0.00 & 0.00 & 0.00 & 0.00 & 0.00 & 0.00 & 0.00 & 0.00 & 0.00 & 0.00 \\
\hline 18 & 0.00 & 0.00 & 0.00 & 0.01 & 0.00 & 0.00 & 0.00 & 0.00 & 0.00 & 0.00 & 0.06 & 0.17 \\
\hline 19 & 0.00 & 0.00 & 0.00 & 0.00 & 0.00 & 0.00 & 0.00 & 0.00 & 0.00 & 0.18 & 0.05 & 0.41 \\
\hline 20 & 0.00 & 0.00 & 0.00 & 0.11 & 0.00 & 0.00 & 0.00 & 0.00 & 0.00 & 0.16 & 0.38 & 0.01 \\
\hline 21 & 0.00 & 0.00 & 0.00 & 0.00 & 0.06 & 0.00 & 0.00 & 0.00 & 0.00 & 0.01 & 0.01 & 0.00 \\
\hline 22 & 0.00 & 0.00 & 0.00 & 0.00 & 0.00 & 0.00 & 0.00 & 0.00 & 0.00 & 0.46 & 0.00 & 0.00 \\
\hline 23 & 0.00 & 0.00 & 0.00 & 0.00 & 0.77 & 0.02 & 0.03 & 0.00 & 0.00 & 0.08 & 0.00 & 0.00 \\
\hline 24 & 0.00 & 0.00 & 0.00 & 0.00 & 0.49 & 0.00 & 0.01 & 0.00 & 0.00 & 0.47 & 0.00 & 0.00 \\
\hline 25 & 0.00 & 0.00 & 0.00 & 0.02 & 0.02 & 0.00 & 0.00 & 0.00 & 0.00 & 0.14 & 0.00 & 0.00 \\
\hline 26 & 0.00 & 0.00 & 0.00 & 0.00 & 0.00 & 0.00 & 0.00 & 0.00 & 0.05 & 0.00 & 0.00 & 0.01 \\
\hline 27 & 0.00 & 0.00 & 0.00 & 0.00 & 0.00 & 0.00 & 0.00 & 0.00 & 0.00 & 0.33 & 0.00 & 0.00 \\
\hline 28 & 0.00 & 0.00 & 0.00 & 0.00 & 0.22 & 0.00 & 0.00 & 0.00 & 0.00 & 0.03 & 0.00 & 0.00 \\
\hline 29 & 0.00 & 0.00 & 0.00 & 0.00 & 0.00 & 0.00 & 0.00 & 0.00 & 0.61 & 0.00 & 0.00 & 0.17 \\
\hline 30 & 0.00 & 0.00 & 0.00 & 0.00 & --- & 0.00 & 0.00 & 0.00 & 0.00 & 0.00 & 0.00 & 0.03 \\
\hline 31 & 0.00 & --- & 0.00 & 0.00 & --- & 0.00 & --- & 0.00 & --- & 0.00 & 0.00 & --- \\
\hline TOTAL & 1.13 & 0.88 & 0.17 & 0.21 & 1.59 & 1.16 & 3.92 & 0.00 & 0.66 & 1.86 & 0.96 & 0.94 \\
\hline MAX & 0.74 & 0.61 & 0.12 & 0.11 & 0.77 & 0.81 & 1.86 & 0.00 & 0.61 & 0.47 & 0.38 & 0.41 \\
\hline MIN & 0.00 & 0.00 & 0.00 & 0.00 & 0.00 & 0.00 & 0.00 & 0.00 & 0.00 & 0.00 & 0.00 & 0.00 \\
\hline
\end{tabular}

CAL YR 2003 TOTAL 7.13 MAX 0.74 MIN 0.00 WTR YR 2004 TOTAL 13.48 MAX $1.86 \quad$ MIN 0.00 


\section{0, TANOAN RAIN GAGE AT ALBUQUERQUE, NEW MEXICO STATION ANALYSIS \\ WATER YEAR 2004}

Location.--35 $09^{\prime} 20^{\prime} \mathrm{N}, 106^{\circ} 31^{\prime} 53^{\prime \prime} \mathrm{W}$. The rain gage is located in northeast Albuquerque at a private office, north of Academy Road between Eubank Boulevard and Ventura Street.

Equipment.--Onset Corporation HOBO Event data recorder and 7.9-inch-diameter tipping bucket. The bucket tips one time per 0.01 inch of rain, and the recorder stores data at 5-minute intervals. Rain gage is calibrated approximately every 2 years and was last calibrated in March 2003.

Record.--The rain gage gave a complete and satisfactory record for the entire water year.

Period of Record.--April 1991 to present.

Remarks.--Record is good for the entire water year.

PRECIPITATION, TOTAL, INCHES, WATER YEAR OCTOBER 2003 TO SEPTEMBER 2004 DAILY SUM VALUES

\begin{tabular}{|c|c|c|c|c|c|c|c|c|c|c|c|c|}
\hline DAY & OCT & NOV & DEC & JAN & FEB & MAR & APR & MAY & JUN & JUL & AUG & SEP \\
\hline 1 & 0.00 & 0.00 & 0.00 & 0.00 & 0.03 & 0.00 & 0.00 & 0.00 & 0.00 & 0.00 & 0.00 & 0.00 \\
\hline 2 & 0.00 & 0.00 & 0.00 & 0.00 & 0.03 & 0.12 & 0.24 & 0.00 & 0.00 & 0.00 & 0.10 & 0.00 \\
\hline 3 & 0.10 & 0.00 & 0.00 & 0.00 & 0.01 & 0.01 & 0.76 & 0.00 & 0.00 & 0.00 & 0.00 & 0.00 \\
\hline 4 & 0.05 & 0.00 & 0.00 & 0.00 & 0.12 & 0.75 & 0.21 & 0.00 & 0.00 & 0.00 & 0.11 & 0.08 \\
\hline 5 & 0.00 & 0.00 & 0.00 & 0.00 & 0.00 & 0.05 & 0.00 & 0.00 & 0.00 & 0.00 & 0.00 & 0.00 \\
\hline 6 & 0.00 & 0.00 & 0.00 & 0.00 & 0.00 & 0.00 & 0.00 & 0.00 & 0.00 & 0.00 & 0.00 & 0.00 \\
\hline 7 & 0.74 & 0.00 & 0.00 & 0.00 & 0.00 & 0.00 & 0.00 & 0.00 & 0.00 & 0.00 & 0.00 & 0.00 \\
\hline 8 & 0.21 & 0.00 & 0.00 & 0.00 & 0.00 & 0.00 & 0.35 & 0.00 & 0.00 & 0.00 & 0.00 & 0.00 \\
\hline 9 & 0.00 & 0.00 & 0.00 & 0.00 & 0.00 & 0.00 & 0.12 & 0.00 & 0.00 & 0.00 & 0.00 & 0.00 \\
\hline 10 & 0.13 & 0.00 & 0.00 & 0.00 & 0.00 & 0.00 & 0.29 & 0.00 & 0.00 & 0.00 & 0.01 & 0.00 \\
\hline 11 & 0.01 & 0.00 & 0.00 & 0.00 & 0.00 & 0.00 & 0.00 & 0.00 & 0.00 & 0.11 & 0.00 & 0.00 \\
\hline 12 & 0.00 & 0.65 & 0.15 & 0.00 & 0.00 & 0.00 & 0.00 & 0.00 & 0.00 & 0.78 & 0.02 & 0.00 \\
\hline 13 & 0.00 & 0.33 & 0.00 & 0.00 & 0.00 & 0.00 & 0.00 & 0.00 & 0.00 & 0.00 & 0.00 & 0.00 \\
\hline 14 & 0.00 & 0.00 & 0.00 & 0.00 & 0.00 & 0.00 & 0.00 & 0.00 & 0.00 & 0.00 & 0.00 & 0.00 \\
\hline 15 & 0.00 & 0.00 & 0.00 & 0.02 & 0.00 & 0.00 & 0.00 & 0.00 & 0.00 & 0.01 & 0.00 & 0.00 \\
\hline 16 & 0.00 & 0.01 & 0.00 & 0.00 & 0.00 & 0.00 & 0.00 & 0.00 & 0.00 & 0.00 & 0.00 & 0.00 \\
\hline 17 & 0.00 & 0.00 & 0.00 & 0.00 & 0.00 & 0.00 & 0.00 & 0.00 & 0.00 & 0.00 & 0.00 & 0.00 \\
\hline 18 & 0.00 & 0.00 & 0.00 & 0.00 & 0.00 & 0.00 & 0.00 & 0.00 & 0.00 & 0.03 & 0.03 & 0.07 \\
\hline 19 & 0.00 & 0.00 & 0.00 & 0.00 & 0.00 & 0.00 & 0.00 & 0.00 & 0.00 & 0.00 & 0.11 & 0.96 \\
\hline 20 & 0.00 & 0.00 & 0.00 & 0.10 & 0.00 & 0.00 & 0.00 & 0.00 & 0.00 & 0.11 & 0.00 & 0.05 \\
\hline 21 & 0.00 & 0.00 & 0.00 & 0.00 & 0.04 & 0.00 & 0.00 & 0.00 & 0.00 & 0.00 & 0.02 & 0.00 \\
\hline 22 & 0.00 & 0.00 & 0.00 & 0.00 & 0.00 & 0.00 & 0.00 & 0.00 & 0.00 & 0.32 & 0.00 & 0.00 \\
\hline 23 & 0.00 & 0.00 & 0.00 & 0.00 & 0.58 & 0.01 & 0.01 & 0.00 & 0.00 & 0.45 & 0.00 & 0.00 \\
\hline 24 & 0.00 & 0.00 & 0.00 & 0.00 & 0.22 & 0.00 & 0.00 & 0.00 & 0.00 & 0.11 & 0.00 & 0.00 \\
\hline 25 & 0.00 & 0.00 & 0.00 & 0.07 & 0.00 & 0.00 & 0.00 & 0.00 & 0.02 & 0.17 & 0.00 & 0.00 \\
\hline 26 & 0.00 & 0.00 & 0.00 & 0.00 & 0.00 & 0.00 & 0.00 & 0.00 & 0.39 & 0.00 & 0.00 & 0.02 \\
\hline 27 & 0.00 & 0.00 & 0.00 & 0.00 & 0.00 & 0.00 & 0.00 & 0.00 & 0.00 & 0.49 & 0.00 & 0.00 \\
\hline 28 & 0.00 & 0.00 & 0.00 & 0.00 & 0.15 & 0.00 & 0.00 & 0.00 & 0.00 & 0.00 & 0.00 & 0.00 \\
\hline 29 & 0.00 & 0.00 & 0.00 & 0.00 & 0.00 & 0.00 & 0.00 & 0.00 & 0.53 & 0.00 & 0.00 & 0.01 \\
\hline 30 & 0.00 & 0.00 & 0.00 & 0.00 & --- & 0.00 & 0.00 & 0.00 & 0.00 & 0.00 & 0.00 & 0.00 \\
\hline 31 & 0.00 & --- & 0.00 & 0.00 & --- & 0.00 & --- & 0.00 & --- & 0.00 & 0.00 & --- \\
\hline TOTAL & 1.24 & 0.99 & 0.15 & 0.19 & 1.18 & 0.94 & 1.98 & 0.00 & 0.94 & 2.58 & 0.40 & 1.19 \\
\hline MAX & 0.74 & 0.65 & 0.15 & 0.10 & 0.58 & 0.75 & 0.76 & 0.00 & 0.53 & 0.78 & 0.11 & 0.96 \\
\hline MIN & 0.00 & 0.00 & 0.00 & 0.00 & 0.00 & 0.00 & 0.00 & 0.00 & 0.00 & 0.00 & 0.00 & 0.00 \\
\hline
\end{tabular}




\section{6, TAYLOR RANCH DRAIN RAIN GAGE AT ALBUQUERQUE, NEW MEXICO STATION ANALYSIS \\ WATER YEAR 2004}

Location.-- $35^{\circ} 08^{\prime} 58^{\prime \prime} \mathrm{N}, 106^{\circ} 42^{\prime} 05^{\prime \prime} \mathrm{W}$. The rain gage is located in northwest Albuquerque on Calle Nuestra Street, near the intersection of Golf Course Road and Montano Road.

Equipment.--Onset Corporation HOBO Event data recorder and 8.2-inch-diameter tipping bucket. The bucket tips one time per 0.01 inch of rain, and the recorder stores data at 5 -minute intervals. Rain gage is calibrated approximately every 2 years and was last calibrated in March 2003.

Record.--The rain gage gave a complete and satisfactory record for the entire water year except for October 8 to 16; during this period the rain gage was plugged. Estimates for these days are based on daily totals recorded at this gage as well as the Petroglyph rain gage.

Period of Record.--June 1984 to present.

Remarks.--Record is good for the entire water year including days estimated as zero; other estimates are poor.

PRECIPITATION, TOTAL, INCHES, WATER YEAR OCTOBER 2003 TO SEPTEMBER 2004 DAILY SUM VALUES

\begin{tabular}{|c|c|c|c|c|c|c|c|c|c|c|c|c|}
\hline DAY & OCT & NOV & DEC & JAN & FEB & MAR & APR & MAY & JUN & JUL & AUG & SEP \\
\hline 1 & 0.00 & 0.00 & 0.00 & 0.00 & 0.00 & 0.00 & 0.00 & 0.00 & 0.00 & 0.00 & 0.00 & 0.00 \\
\hline 2 & 0.00 & 0.00 & 0.00 & 0.00 & 0.00 & 0.28 & 1.15 & 0.00 & 0.00 & 0.00 & 0.07 & 0.00 \\
\hline 3 & 0.15 & 0.00 & 0.00 & 0.00 & 0.07 & 0.00 & 2.76 & 0.00 & 0.00 & 0.00 & 0.00 & 0.00 \\
\hline 4 & 0.04 & 0.00 & 0.00 & 0.00 & 0.00 & 1.08 & 0.21 & 0.00 & 0.00 & 0.00 & 0.00 & 0.08 \\
\hline 5 & 0.00 & 0.00 & 0.00 & 0.00 & 0.00 & 0.02 & 0.00 & 0.00 & 0.00 & 0.00 & 0.01 & 0.00 \\
\hline 6 & 0.00 & 0.00 & 0.00 & 0.00 & 0.00 & 0.00 & 0.00 & 0.00 & 0.00 & 0.00 & 0.00 & 0.00 \\
\hline 7 & 1.15 & 0.00 & 0.00 & 0.00 & 0.00 & 0.00 & 0.00 & 0.00 & 0.00 & 0.00 & 0.00 & 0.00 \\
\hline 8 & $\mathrm{e} 0.37$ & 0.00 & 0.23 & 0.00 & 0.00 & 0.00 & 0.41 & 0.00 & 0.00 & 0.00 & 0.00 & 0.00 \\
\hline 9 & e0.00 & 0.00 & 0.00 & 0.00 & 0.00 & 0.00 & 0.00 & 0.00 & 0.00 & 0.00 & 0.00 & 0.00 \\
\hline 10 & $\mathrm{e} 0.00$ & 0.00 & 0.00 & 0.00 & 0.00 & 0.00 & 0.41 & 0.00 & 0.00 & 0.00 & 0.00 & 0.00 \\
\hline 11 & e0.00 & 0.00 & 0.00 & 0.00 & 0.00 & 0.00 & 0.00 & 0.00 & 0.00 & 0.00 & 0.07 & 0.00 \\
\hline 12 & $\mathrm{e} 0.00$ & 0.90 & 0.37 & 0.00 & 0.00 & 0.00 & 0.00 & 0.00 & 0.00 & 0.05 & 0.00 & 0.00 \\
\hline 13 & $\mathrm{e} 0.00$ & 0.32 & 0.00 & 0.00 & 0.00 & 0.00 & 0.00 & 0.00 & 0.00 & 0.00 & 0.09 & 0.00 \\
\hline 14 & $\mathrm{e} 0.00$ & 0.00 & 0.00 & 0.00 & 0.00 & 0.00 & 0.00 & 0.00 & 0.00 & 0.00 & 0.00 & 0.00 \\
\hline 15 & $\mathrm{e} 0.00$ & 0.01 & 0.00 & 0.06 & 0.00 & 0.00 & 0.00 & 0.00 & 0.00 & 0.00 & 0.00 & 0.00 \\
\hline 16 & e0.00 & 0.01 & 0.00 & 0.01 & 0.00 & 0.00 & 0.00 & 0.00 & 0.00 & 0.00 & 0.00 & 0.00 \\
\hline 17 & 0.00 & 0.00 & 0.00 & 0.00 & 0.00 & 0.00 & 0.00 & 0.00 & 0.00 & 0.00 & 0.00 & 0.00 \\
\hline 18 & 0.00 & 0.00 & 0.00 & 0.00 & 0.00 & 0.00 & 0.00 & 0.00 & 0.00 & 0.00 & 0.00 & 0.15 \\
\hline 19 & 0.00 & 0.00 & 0.00 & 0.00 & 0.00 & 0.00 & 0.00 & 0.00 & 0.00 & 0.14 & 0.00 & 0.41 \\
\hline 20 & 0.00 & 0.00 & 0.00 & 0.08 & 0.00 & 0.00 & 0.00 & 0.00 & 0.00 & 0.16 & 0.00 & 0.02 \\
\hline 21 & 0.00 & 0.00 & 0.00 & 0.01 & 0.08 & 0.00 & 0.00 & 0.00 & 0.00 & 0.00 & 0.00 & 0.00 \\
\hline 22 & 0.00 & 0.00 & 0.00 & 0.00 & 0.02 & 0.00 & 0.00 & 0.00 & 0.00 & 0.37 & 0.00 & 0.00 \\
\hline 23 & 0.00 & 0.00 & 0.00 & 0.00 & 1.24 & 0.01 & 0.01 & 0.00 & 0.00 & 0.14 & 0.00 & 0.00 \\
\hline 24 & 0.00 & 0.00 & 0.00 & 0.00 & 1.13 & 0.00 & 0.00 & 0.00 & 0.00 & 0.17 & 0.00 & 0.00 \\
\hline 25 & 0.00 & 0.00 & 0.00 & 0.04 & 0.01 & 0.00 & 0.00 & 0.00 & 0.00 & 0.22 & 0.00 & 0.00 \\
\hline 26 & 0.00 & 0.00 & 0.00 & 0.00 & 0.00 & 0.00 & 0.00 & 0.00 & 0.00 & 0.00 & 0.00 & 0.00 \\
\hline 27 & 0.00 & 0.00 & 0.00 & 0.00 & 0.00 & 0.00 & 0.00 & 0.00 & 0.00 & 0.06 & 0.00 & 0.00 \\
\hline 28 & 0.00 & 0.00 & 0.00 & 0.00 & 0.48 & 0.00 & 0.00 & 0.00 & 0.00 & 0.00 & 0.00 & 0.00 \\
\hline 29 & 0.00 & 0.00 & 0.00 & 0.00 & 0.00 & 0.00 & 0.00 & 0.00 & 1.13 & 0.00 & 0.00 & 0.36 \\
\hline 30 & 0.00 & 0.00 & 0.00 & 0.00 & --- & 0.00 & 0.00 & 0.00 & 0.00 & 0.00 & 0.00 & 0.01 \\
\hline 31 & 0.00 & --- & 0.00 & 0.00 & --- & 0.00 & --- & 0.00 & --- & 0.00 & 0.00 & --- \\
\hline TOTAL & 1.71 & 1.24 & 0.60 & 0.20 & 3.03 & 1.39 & 4.95 & 0.00 & 1.13 & 1.31 & 0.24 & 1.03 \\
\hline MAX & 1.15 & 0.90 & 0.37 & 0.08 & 1.24 & 1.08 & 2.76 & 0.00 & 1.13 & 0.37 & 0.09 & 0.41 \\
\hline MIN & 0.00 & 0.00 & 0.00 & 0.00 & 0.00 & 0.00 & 0.00 & 0.00 & 0.00 & 0.00 & 0.00 & 0.00 \\
\hline
\end{tabular}

CAL YR 2003 TOTAL 9.61 MAX 1.15 MIN 0.00

WTR YR 2004 TOTAL 16.83 MAX 2.76 MIN 0.00 


\section{0, THOMAS PUMP STATION RAIN GAGE AT ALBUQUERQUE, NEW MEXICO STATION ANALYSIS \\ WATER YEAR 2004}

Location.--35 $07^{\prime} 56^{\prime \prime} \mathrm{N}, 106^{\circ} 33^{\prime} 01^{\prime}$ 'W. The rain gage is located in northeast Albuquerque, approximately 0.25 mile northeast of the intersection of Montgomery and Wyoming Boulevards.

Equipment.--Onset Corporation HOBO Event data recorder and 7.9-inch-diameter tipping bucket. The bucket tips one time per 0.01 inch of rain, and the recorder stores data at 5-minute intervals. Rain gage is calibrated approximately every 2 years and was last calibrated in March 2003.

Record.--The rain gage gave a complete and satisfactory record for the entire water year.

Period of Record.--October 1994 to present.

Remarks.--Record is good for the entire water year.

PRECIPITATION, TOTAL, INCHES, WATER YEAR OCTOBER 2003 TO SEPTEMBER 2004 DAILY SUM VALUES

\begin{tabular}{|c|c|c|c|c|c|c|c|c|c|c|c|c|}
\hline DAY & ост & NOV & DEC & JAN & FEB & MAR & APR & MAY & JUN & JUL & AUG & SEP \\
\hline 1 & 0.00 & 0.00 & 0.00 & 0.00 & 0.07 & 0.00 & 0.00 & 0.00 & 0.00 & 0.00 & 0.00 & 0.00 \\
\hline 2 & 0.00 & 0.00 & 0.00 & 0.00 & 0.00 & 0.12 & 0.26 & 0.00 & 0.00 & 0.00 & 0.10 & 0.00 \\
\hline 3 & 0.07 & 0.00 & 0.00 & 0.00 & 0.00 & 0.01 & 0.77 & 0.00 & 0.00 & 0.00 & 0.00 & 0.00 \\
\hline 4 & 0.03 & 0.00 & 0.00 & 0.00 & 0.09 & 0.79 & 0.12 & 0.00 & 0.00 & 0.00 & 0.18 & 0.08 \\
\hline 5 & 0.00 & 0.00 & 0.00 & 0.00 & 0.00 & 0.05 & 0.00 & 0.00 & 0.00 & 0.00 & 0.01 & 0.00 \\
\hline 6 & 0.00 & 0.00 & 0.00 & 0.00 & 0.00 & 0.00 & 0.00 & 0.00 & 0.00 & 0.00 & 0.00 & 0.00 \\
\hline 7 & 0.94 & 0.00 & 0.00 & 0.00 & 0.00 & 0.00 & 0.00 & 0.00 & 0.00 & 0.00 & 0.00 & 0.00 \\
\hline 8 & 0.22 & 0.00 & 0.00 & 0.00 & 0.00 & 0.00 & 0.37 & 0.00 & 0.00 & 0.00 & 0.00 & 0.00 \\
\hline 9 & 0.00 & 0.00 & 0.00 & 0.00 & 0.00 & 0.00 & 0.07 & 0.00 & 0.00 & 0.00 & 0.00 & 0.00 \\
\hline 10 & 0.14 & 0.00 & 0.00 & 0.00 & 0.00 & 0.00 & 0.28 & 0.00 & 0.00 & 0.00 & 0.02 & 0.00 \\
\hline 11 & 0.01 & 0.00 & 0.00 & 0.00 & 0.00 & 0.00 & 0.00 & 0.00 & 0.00 & 0.01 & 0.00 & 0.00 \\
\hline 12 & 0.00 & 0.68 & 0.12 & 0.00 & 0.00 & 0.00 & 0.00 & 0.00 & 0.00 & 0.55 & 0.02 & 0.00 \\
\hline 13 & 0.00 & 0.28 & 0.00 & 0.00 & 0.00 & 0.00 & 0.00 & 0.00 & 0.00 & 0.00 & 0.00 & 0.00 \\
\hline 14 & 0.00 & 0.00 & 0.00 & 0.00 & 0.00 & 0.00 & 0.00 & 0.00 & 0.00 & 0.06 & 0.00 & 0.00 \\
\hline 15 & 0.00 & 0.00 & 0.00 & 0.00 & 0.00 & 0.00 & 0.00 & 0.00 & 0.00 & 0.00 & 0.00 & 0.00 \\
\hline 16 & 0.00 & 0.03 & 0.00 & 0.01 & 0.00 & 0.00 & 0.00 & 0.00 & 0.00 & 0.00 & 0.00 & 0.00 \\
\hline 17 & 0.00 & 0.03 & 0.00 & 0.00 & 0.00 & 0.00 & 0.00 & 0.00 & 0.00 & 0.00 & 0.00 & 0.00 \\
\hline 18 & 0.00 & 0.00 & 0.00 & 0.00 & 0.00 & 0.00 & 0.00 & 0.00 & 0.00 & 0.01 & 0.00 & 0.10 \\
\hline 19 & 0.00 & 0.00 & 0.00 & 0.00 & 0.00 & 0.01 & 0.00 & 0.00 & 0.00 & 0.00 & 0.01 & 1.00 \\
\hline 20 & 0.00 & 0.00 & 0.00 & 0.09 & 0.00 & 0.00 & 0.00 & 0.00 & 0.00 & 0.10 & 0.01 & 0.06 \\
\hline 21 & 0.00 & 0.00 & 0.00 & 0.01 & 0.07 & 0.00 & 0.00 & 0.00 & 0.00 & 0.03 & 0.02 & 0.00 \\
\hline 22 & 0.00 & 0.00 & 0.00 & 0.00 & 0.00 & 0.00 & 0.00 & 0.00 & 0.00 & 0.00 & 0.00 & 0.00 \\
\hline 23 & 0.00 & 0.00 & 0.00 & 0.00 & 0.82 & 0.03 & 0.00 & 0.00 & 0.00 & 0.70 & 0.00 & 0.00 \\
\hline 24 & 0.00 & 0.00 & 0.00 & 0.00 & 0.31 & 0.01 & 0.00 & 0.00 & 0.00 & 0.16 & 0.00 & 0.00 \\
\hline 25 & 0.00 & 0.00 & 0.00 & 0.04 & 0.00 & 0.00 & 0.00 & 0.00 & 0.00 & 0.21 & 0.00 & 0.00 \\
\hline 26 & 0.00 & 0.00 & 0.00 & 0.00 & 0.00 & 0.00 & 0.00 & 0.00 & 0.14 & 0.00 & 0.00 & 0.00 \\
\hline 27 & 0.00 & 0.00 & 0.00 & 0.00 & 0.00 & 0.00 & 0.00 & 0.00 & 0.00 & 0.65 & 0.00 & 0.00 \\
\hline 28 & 0.00 & 0.00 & 0.00 & 0.00 & 0.15 & 0.00 & 0.00 & 0.00 & 0.00 & 0.03 & 0.00 & 0.00 \\
\hline 29 & 0.00 & 0.00 & 0.00 & 0.00 & 0.00 & 0.00 & 0.00 & 0.00 & 0.39 & 0.00 & 0.00 & 0.00 \\
\hline 30 & 0.00 & 0.00 & 0.00 & 0.00 & --- & 0.00 & 0.00 & 0.00 & 0.00 & 0.00 & 0.00 & 0.00 \\
\hline 31 & 0.00 & --- & 0.00 & 0.00 & --- & 0.00 & --- & 0.00 & --- & 0.00 & 0.00 & --- \\
\hline TOTAL & 1.41 & 1.02 & 0.12 & 0.15 & 1.51 & 1.02 & 1.87 & 0.00 & 0.53 & 2.51 & 0.37 & 1.24 \\
\hline MAX & 0.94 & 0.68 & 0.12 & 0.09 & 0.82 & 0.79 & 0.77 & 0.00 & 0.39 & 0.70 & 0.18 & 1.00 \\
\hline MIN & 0.00 & 0.00 & 0.00 & 0.00 & 0.00 & 0.00 & 0.00 & 0.00 & 0.00 & 0.00 & 0.00 & 0.00 \\
\hline
\end{tabular}

CAL YR 2003 TOTAL 6.47 MAX 0.94 MIN 0.00

WTR YR 2004 TOTAL 11.75 MAX 1.00 MIN 0.00 


\section{0, TIJERAS ARROYO AT MONTESSA PARK RAIN GAGE NEAR ALBUQUERQUE, NEW MEXICO \\ STATION ANALYSIS \\ WATER YEAR 2004}

Location.--35 $01^{\prime} 11^{\prime \prime} \mathrm{N}, 106^{\circ} 35^{\prime} 58^{\prime \prime} \mathrm{W}$. The rain gage is located in far southeast Albuquerque at a discontinued surface-water gage, approximately 2 miles east of Bobby Foster Road and the I-25 overpass.

Equipment.--Onset Corporation HOBO Event data recorder and 7.9-inch-diameter tipping bucket. The bucket tips one time per 0.01 inch of rain, and the recorder stores data at 5-minute intervals. Rain gage is calibrated approximately every 2 years and was last calibrated in March 2003.

Record.--The rain gage gave a complete and satisfactory record for the entire water year.

Period of Record.--October 1994 to present.

Remarks.--Record is good for the entire water year.

PRECIPITATION, TOTAL, INCHES, WATER YEAR OCTOBER 2003 TO SEPTEMBER 2004 DAILY SUM VALUES

\begin{tabular}{|c|c|c|c|c|c|c|c|c|c|c|c|c|}
\hline DAY & OCT & Nov & DEC & JAN & FEB & MAR & APR & MAY & JUN & JUL & AUG & SEP \\
\hline 1 & 0.00 & 0.00 & 0.00 & 0.00 & 0.00 & 0.00 & 0.00 & 0.00 & 0.00 & 0.00 & 0.00 & 0.00 \\
\hline 2 & 0.00 & 0.00 & 0.00 & 0.00 & 0.00 & 0.06 & 0.39 & 0.00 & 0.00 & 0.00 & 0.11 & 0.00 \\
\hline 3 & 0.07 & 0.00 & 0.01 & 0.00 & 0.03 & 0.00 & 1.38 & 0.00 & 0.00 & 0.00 & 0.00 & 0.00 \\
\hline 4 & 0.03 & 0.00 & 0.00 & 0.00 & 0.00 & 0.53 & 0.05 & 0.00 & 0.00 & 0.00 & 0.00 & 0.08 \\
\hline 5 & 0.00 & 0.00 & 0.00 & 0.00 & 0.00 & 0.03 & 0.00 & 0.00 & 0.00 & 0.00 & 0.00 & 0.00 \\
\hline 6 & 0.00 & 0.00 & 0.00 & 0.00 & 0.00 & 0.00 & 0.00 & 0.00 & 0.00 & 0.00 & 0.00 & 0.00 \\
\hline 7 & 1.02 & 0.00 & 0.00 & 0.00 & 0.00 & 0.00 & 0.00 & 0.00 & 0.00 & 0.00 & 0.00 & 0.00 \\
\hline 8 & 0.17 & 0.00 & 0.00 & 0.00 & 0.00 & 0.00 & 0.27 & 0.00 & 0.00 & 0.00 & 0.00 & 0.00 \\
\hline 9 & 0.00 & 0.00 & 0.00 & 0.00 & 0.00 & 0.00 & 0.00 & 0.00 & 0.00 & 0.00 & 0.00 & 0.00 \\
\hline 10 & 0.04 & 0.00 & 0.00 & 0.00 & 0.00 & 0.00 & 0.13 & 0.00 & 0.00 & 0.00 & 0.07 & 0.00 \\
\hline 11 & 0.00 & 0.00 & 0.00 & 0.00 & 0.00 & 0.00 & 0.00 & 0.00 & 0.00 & 0.00 & 0.00 & 0.00 \\
\hline 12 & 0.00 & 0.39 & 0.14 & 0.00 & 0.00 & 0.00 & 0.00 & 0.00 & 0.00 & 0.00 & 0.00 & 0.00 \\
\hline 13 & 0.00 & 0.11 & 0.00 & 0.00 & 0.00 & 0.00 & 0.00 & 0.00 & 0.00 & 0.00 & 0.00 & 0.00 \\
\hline 14 & 0.00 & 0.00 & 0.00 & 0.00 & 0.00 & 0.00 & 0.00 & 0.00 & 0.00 & 0.01 & 0.00 & 0.00 \\
\hline 15 & 0.00 & 0.00 & 0.00 & 0.02 & 0.00 & 0.00 & 0.00 & 0.00 & 0.00 & 0.00 & 0.00 & 0.00 \\
\hline 16 & 0.00 & 0.00 & 0.00 & 0.00 & 0.00 & 0.00 & 0.00 & 0.00 & 0.00 & 0.00 & 0.00 & 0.00 \\
\hline 17 & 0.00 & 0.00 & 0.00 & 0.00 & 0.00 & 0.00 & 0.00 & 0.00 & 0.00 & 0.00 & 0.00 & 0.00 \\
\hline 18 & 0.00 & 0.00 & 0.00 & 0.00 & 0.00 & 0.00 & 0.00 & 0.00 & 0.00 & 0.03 & 0.01 & 0.03 \\
\hline 19 & 0.00 & 0.00 & 0.00 & 0.00 & 0.00 & 0.00 & 0.00 & 0.00 & 0.00 & 0.00 & 0.01 & 0.62 \\
\hline 20 & 0.00 & 0.00 & 0.00 & 0.06 & 0.00 & 0.00 & 0.00 & 0.00 & 0.00 & 0.04 & 0.00 & 0.07 \\
\hline 21 & 0.00 & 0.00 & 0.00 & 0.00 & 0.05 & 0.00 & 0.00 & 0.00 & 0.00 & 0.02 & 0.00 & 0.00 \\
\hline 22 & 0.00 & 0.00 & 0.00 & 0.00 & 0.00 & 0.00 & 0.00 & 0.00 & 0.01 & 0.17 & 0.00 & 0.00 \\
\hline 23 & 0.00 & 0.00 & 0.00 & 0.00 & 0.92 & 0.03 & 0.00 & 0.00 & 0.00 & 0.56 & 0.00 & 0.00 \\
\hline 24 & 0.00 & 0.00 & 0.00 & 0.00 & 0.23 & 0.00 & 0.00 & 0.00 & 0.00 & 0.23 & 0.00 & 0.00 \\
\hline 25 & 0.00 & 0.00 & 0.00 & 0.00 & 0.00 & 0.00 & 0.00 & 0.00 & 0.00 & 0.53 & 0.00 & 0.00 \\
\hline 26 & 0.00 & 0.00 & 0.00 & 0.00 & 0.00 & 0.00 & 0.00 & 0.00 & 0.00 & 0.00 & 0.00 & 0.00 \\
\hline 27 & 0.00 & 0.00 & 0.00 & 0.00 & 0.00 & 0.01 & 0.00 & 0.00 & 0.00 & 0.07 & 0.00 & 0.00 \\
\hline 28 & 0.00 & 0.00 & 0.00 & 0.00 & 0.09 & 0.00 & 0.00 & 0.00 & 0.00 & 0.00 & 0.00 & 0.00 \\
\hline 29 & 0.00 & 0.00 & 0.00 & 0.00 & 0.00 & 0.00 & 0.00 & 0.00 & 0.42 & 0.00 & 0.00 & 0.00 \\
\hline 30 & 0.00 & 0.00 & 0.00 & 0.00 & --- & 0.00 & 0.00 & 0.00 & 0.00 & 0.00 & 0.02 & 0.00 \\
\hline 31 & 0.00 & --- & 0.00 & 0.00 & --- & 0.00 & --- & 0.00 & --- & 0.00 & 0.00 & --- \\
\hline TOTAL & 1.33 & 0.50 & 0.15 & 0.08 & 1.32 & 0.66 & 2.22 & 0.00 & 0.43 & 1.66 & 0.22 & 0.80 \\
\hline MAX & 1.02 & 0.39 & 0.14 & 0.06 & 0.92 & 0.53 & 1.38 & 0.00 & 0.42 & 0.56 & 0.11 & 0.62 \\
\hline MIN & 0.00 & 0.00 & 0.00 & 0.00 & 0.00 & 0.00 & 0.00 & 0.00 & 0.00 & 0.00 & 0.00 & 0.00 \\
\hline
\end{tabular}

CAL YR 2003 TOTAL 6.19 MAX 1.02 MIN 0.00

WTR YR 2004 TOTAL 9.37 MAX 1.38 MIN 0.00 


\section{0, TM KELLY RAIN GAGE AT RIO RANCHO, NEW MEXICO STATION ANALYSIS \\ WATER YEAR 2004}

Location.--35 $15^{\prime} 16^{\prime} \mathrm{N}, 106^{\circ} 43^{\prime} 14^{\prime \prime} \mathrm{W}$. The rain gage is located on private property in Rio Rancho, approximately 2 miles north of the Albuquerque City Limit. This property is located northeast of the intersection of Southern and Rainbow Boulevards.

Equipment.--Onset Corporation HOBO Event data recorder and 6.5-inch-diameter tipping bucket. The bucket tips one time per 0.01 inch of rain, and the recorder stores data at 5-minute intervals. Rain gage is calibrated approximately every 2 years and was last calibrated in April 2003.

Record.--The rain gage gave a complete and satisfactory record for the entire period of record.

Period of Record.--October 2000 to present. This is the first year of record for this gage.

Remarks.--Record is good for the entire period of record.

PRECIPITATION, TOTAL, INCHES, WATER YEAR OCTOBER 2003 TO SEPTEMBER 2004 DAILY SUM VALUES

\begin{tabular}{|c|c|c|c|c|c|c|c|c|c|c|c|c|}
\hline DAY & ОСт & NOV & DEC & JAN & FEB & MAR & APR & MAY & JUN & JUL & AUG & SEP \\
\hline 1 & 0.00 & 0.02 & 0.00 & 0.00 & 0.00 & 0.00 & 0.00 & 0.00 & 0.00 & 0.00 & 0.00 & 0.00 \\
\hline 2 & 0.00 & 0.00 & 0.00 & 0.00 & 0.00 & 0.18 & 0.74 & 0.00 & 0.00 & 0.00 & 0.25 & 0.00 \\
\hline 3 & 0.14 & 0.00 & 0.00 & 0.00 & 0.00 & 0.10 & 1.93 & 0.00 & 0.00 & 0.00 & 0.01 & 0.00 \\
\hline 4 & 0.06 & 0.00 & 0.00 & 0.00 & 0.00 & 0.71 & 0.33 & 0.00 & 0.00 & 0.00 & 0.17 & 0.13 \\
\hline 5 & 0.00 & 0.00 & 0.00 & 0.00 & 0.00 & 0.03 & 0.00 & 0.00 & 0.00 & 0.00 & 0.03 & 0.00 \\
\hline 6 & 0.00 & 0.00 & 0.00 & 0.00 & 0.00 & 0.00 & 0.00 & 0.00 & 0.00 & 0.00 & 0.00 & 0.00 \\
\hline 7 & 0.54 & 0.00 & 0.00 & 0.00 & 0.00 & 0.00 & 0.00 & 0.00 & 0.00 & 0.00 & 0.00 & 0.00 \\
\hline 8 & 0.16 & 0.00 & 0.01 & 0.00 & 0.00 & 0.00 & 0.36 & 0.00 & 0.00 & 0.00 & 0.00 & 0.00 \\
\hline 9 & 0.00 & 0.00 & 0.00 & 0.00 & 0.00 & 0.00 & 0.08 & 0.00 & 0.00 & 0.00 & 0.00 & 0.00 \\
\hline 10 & 0.16 & 0.01 & 0.00 & 0.00 & 0.00 & 0.00 & 0.61 & 0.00 & 0.00 & 0.09 & 0.02 & 0.00 \\
\hline 11 & 0.01 & 0.00 & 0.00 & 0.00 & 0.00 & 0.00 & 0.03 & 0.01 & 0.00 & 0.00 & 0.00 & 0.00 \\
\hline 12 & 0.00 & 0.73 & 0.13 & 0.00 & 0.06 & 0.00 & 0.01 & 0.00 & 0.00 & 0.05 & 0.00 & 0.00 \\
\hline 13 & 0.00 & 0.22 & 0.00 & 0.00 & 0.00 & 0.00 & 0.00 & 0.00 & 0.00 & 0.00 & 0.33 & 0.00 \\
\hline 14 & 0.00 & 0.01 & 0.00 & 0.00 & 0.00 & 0.00 & 0.00 & 0.00 & 0.00 & 0.00 & 0.01 & 0.00 \\
\hline 15 & 0.00 & 0.01 & 0.00 & 0.08 & 0.00 & 0.00 & 0.00 & 0.00 & 0.00 & 0.00 & 0.00 & 0.00 \\
\hline 16 & 0.00 & 0.00 & 0.00 & 0.00 & 0.00 & 0.00 & 0.00 & 0.00 & 0.00 & 0.00 & 0.00 & 0.00 \\
\hline 17 & 0.00 & 0.02 & 0.00 & 0.00 & 0.00 & 0.00 & 0.00 & 0.00 & 0.00 & 0.00 & 0.00 & 0.00 \\
\hline 18 & 0.00 & 0.00 & 0.00 & 0.00 & 0.00 & 0.00 & 0.00 & 0.00 & 0.00 & 0.00 & 0.03 & 0.14 \\
\hline 19 & 0.00 & 0.00 & 0.00 & 0.00 & 0.00 & 0.00 & 0.00 & 0.00 & 0.00 & 0.15 & 0.03 & 0.36 \\
\hline 20 & 0.00 & 0.00 & 0.00 & 0.10 & 0.00 & 0.00 & 0.00 & 0.00 & 0.00 & 0.01 & 0.00 & 0.01 \\
\hline 21 & 0.00 & 0.00 & 0.00 & 0.01 & 0.03 & 0.00 & 0.00 & 0.00 & 0.00 & 0.00 & 0.00 & 0.00 \\
\hline 22 & 0.00 & 0.00 & 0.00 & 0.00 & 0.01 & 0.00 & 0.00 & 0.00 & 0.00 & 0.09 & 0.00 & 0.00 \\
\hline 23 & 0.00 & 0.00 & 0.00 & 0.00 & 0.49 & 0.00 & 0.04 & 0.00 & 0.00 & 0.11 & 0.00 & 0.00 \\
\hline 24 & 0.00 & 0.00 & 0.00 & 0.00 & 0.70 & 0.00 & 0.00 & 0.00 & 0.00 & 0.54 & 0.00 & 0.00 \\
\hline 25 & 0.00 & 0.00 & 0.00 & 0.01 & 0.05 & 0.00 & 0.00 & 0.00 & 0.00 & 0.13 & 0.00 & 0.00 \\
\hline 26 & 0.00 & 0.00 & 0.00 & 0.00 & 0.00 & 0.00 & 0.00 & 0.00 & 0.47 & 0.00 & 0.00 & 0.00 \\
\hline 27 & 0.00 & 0.00 & 0.00 & 0.00 & 0.00 & 0.00 & 0.00 & 0.00 & 0.00 & 0.13 & 0.00 & 0.06 \\
\hline 28 & 0.00 & 0.00 & 0.00 & 0.00 & 0.25 & 0.00 & 0.00 & 0.00 & 0.00 & 0.03 & 0.00 & 0.00 \\
\hline 29 & 0.00 & 0.00 & 0.00 & 0.00 & 0.03 & 0.00 & 0.00 & 0.00 & 0.92 & 0.00 & 0.00 & 0.40 \\
\hline 30 & 0.00 & 0.00 & 0.00 & 0.00 & --- & 0.00 & 0.00 & 0.00 & 0.00 & 0.00 & 0.00 & 0.03 \\
\hline 31 & 0.00 & --- & 0.00 & 0.00 & --- & 0.00 & --- & 0.00 & --- & 0.00 & 0.00 & --- \\
\hline TOTAL & 1.07 & 1.02 & 0.14 & 0.20 & 1.62 & 1.02 & 4.13 & 0.01 & 1.39 & 1.33 & 0.88 & 1.13 \\
\hline MAX & 0.54 & 0.73 & 0.13 & 0.10 & 0.70 & 0.71 & 1.93 & 0.01 & 0.92 & 0.54 & 0.33 & 0.40 \\
\hline MIN & 0.00 & 0.00 & 0.00 & 0.00 & 0.00 & 0.00 & 0.00 & 0.00 & 0.00 & 0.00 & 0.00 & 0.00 \\
\hline
\end{tabular}

CAL YR 2003 TOTAL 7.05 MAX 0.73 MIN 0.00

WTR YR 2004 TOTAL 13.94 MAX 1.93 MIN 0.00 


\section{0, TRAMWAY FLOODWAY CHANNEL RAIN GAGE AT ALBUQUERQUE, NEW MEXICO STATION ANALYSIS \\ WATER YEAR 2004}

Location.--35 $04^{\prime} 42^{\prime \prime} \mathrm{N}, 106^{\circ} 29^{\prime} 49^{\prime \prime} \mathrm{W}$. The rain gage is located in northeast Albuquerque at a surface-water gage, approximately 200 feet south of the intersection of Tramway Boulevard and Copper Street.

Equipment.--8.0-inch-diameter tipping bucket connected to a surface-water data recorder. The bucket tips one time per 0.01 inch of rain, and the recorder stores data at 5-minute intervals. Rain gage is calibrated approximately every 2 years and was last calibrated in March 2003.

Record.--The rain gage gave a complete and satisfactory record for the entire water year.

Period of Record.--May 2001 to present.

Remarks.--Record is good for the entire water year.

PRECIPITATION, TOTAL, INCHES, WATER YEAR OCTOBER 2003 TO SEPTEMBER 2004 DAILY SUM VALUES

\begin{tabular}{|c|c|c|c|c|c|c|c|c|c|c|c|c|}
\hline DAY & ОСт & NOV & $\mathrm{DEC}$ & JAN & FEB & MAR & APR & MAY & JUN & JUL & AUG & SEP \\
\hline 1 & 0.00 & 0.00 & 0.00 & 0.00 & 0.13 & 0.00 & 0.00 & 0.00 & 0.00 & 0.00 & 0.00 & 0.00 \\
\hline 2 & 0.00 & 0.00 & 0.00 & 0.00 & 0.01 & 0.09 & 0.23 & 0.00 & 0.00 & 0.00 & 0.23 & 0.00 \\
\hline 3 & 0.07 & 0.00 & 0.00 & 0.00 & 0.00 & 0.00 & 1.50 & 0.00 & 0.00 & 0.00 & 0.00 & 0.00 \\
\hline 4 & 0.00 & 0.00 & 0.00 & 0.00 & 0.01 & 0.72 & 0.45 & 0.00 & 0.00 & 0.00 & 1.48 & 0.14 \\
\hline 5 & 0.00 & 0.00 & 0.00 & 0.00 & 0.00 & 0.11 & 0.00 & 0.00 & 0.00 & 0.00 & 0.00 & 0.00 \\
\hline 6 & 0.00 & 0.00 & 0.00 & 0.00 & 0.00 & 0.00 & 0.00 & 0.00 & 0.00 & 0.00 & 0.00 & 0.00 \\
\hline 7 & 0.93 & 0.00 & 0.00 & 0.00 & 0.00 & 0.00 & 0.00 & 0.00 & 0.00 & 0.00 & 0.00 & 0.00 \\
\hline 8 & 0.17 & 0.00 & 0.01 & 0.00 & 0.00 & 0.00 & 0.33 & 0.00 & 0.00 & 0.00 & 0.00 & 0.00 \\
\hline 9 & 0.00 & 0.00 & 0.00 & 0.00 & 0.00 & 0.00 & 0.07 & 0.00 & 0.00 & 0.00 & 0.00 & 0.00 \\
\hline 10 & 0.22 & 0.00 & 0.00 & 0.00 & 0.00 & 0.00 & 0.26 & 0.00 & 0.00 & 0.01 & 0.05 & 0.00 \\
\hline 11 & 0.00 & 0.01 & 0.00 & 0.00 & 0.00 & 0.00 & 0.00 & 0.00 & 0.00 & 0.00 & 0.00 & 0.00 \\
\hline 12 & 0.00 & 0.56 & 0.21 & 0.00 & 0.00 & 0.00 & 0.00 & 0.00 & 0.00 & 0.00 & 0.02 & 0.00 \\
\hline 13 & 0.00 & 0.47 & 0.00 & 0.00 & 0.00 & 0.00 & 0.00 & 0.00 & 0.00 & 0.00 & 0.00 & 0.00 \\
\hline 14 & 0.00 & 0.00 & 0.00 & 0.00 & 0.00 & 0.00 & 0.00 & 0.00 & 0.00 & 0.06 & 0.00 & 0.00 \\
\hline 15 & 0.00 & 0.00 & 0.00 & 0.09 & 0.00 & 0.00 & 0.00 & 0.00 & 0.00 & 0.00 & 0.00 & 0.00 \\
\hline 16 & 0.00 & 0.00 & 0.00 & 0.00 & 0.00 & 0.00 & 0.00 & 0.00 & 0.00 & 0.00 & 0.00 & 0.00 \\
\hline 17 & 0.00 & 0.02 & 0.00 & 0.02 & 0.00 & 0.00 & 0.00 & 0.00 & 0.00 & 0.00 & 0.00 & 0.00 \\
\hline 18 & 0.00 & 0.00 & 0.00 & 0.00 & 0.00 & 0.00 & 0.00 & 0.00 & 0.00 & 0.01 & 0.01 & 0.08 \\
\hline 19 & 0.00 & 0.00 & 0.00 & 0.00 & 0.00 & 0.00 & 0.00 & 0.00 & 0.00 & 0.00 & 0.02 & 0.53 \\
\hline 20 & 0.00 & 0.00 & 0.00 & 0.15 & 0.00 & 0.00 & 0.00 & 0.00 & 0.00 & 0.15 & 0.00 & 0.17 \\
\hline 21 & 0.00 & 0.00 & 0.00 & 0.00 & 0.13 & 0.00 & 0.00 & 0.00 & 0.00 & 0.02 & 0.04 & 0.00 \\
\hline 22 & 0.00 & 0.00 & 0.00 & 0.00 & 0.00 & 0.00 & 0.00 & 0.00 & 0.14 & 0.34 & 0.03 & 0.00 \\
\hline 23 & 0.00 & 0.00 & 0.00 & 0.00 & 0.91 & 0.04 & 0.00 & 0.00 & 0.00 & 0.47 & 0.00 & 0.00 \\
\hline 24 & 0.00 & 0.00 & 0.00 & 0.00 & 0.37 & 0.01 & 0.00 & 0.00 & 0.00 & 0.10 & 0.00 & 0.00 \\
\hline 25 & 0.00 & 0.00 & 0.00 & 0.06 & 0.01 & 0.00 & 0.00 & 0.00 & 0.00 & 0.18 & 0.00 & 0.00 \\
\hline 26 & 0.00 & 0.00 & 0.00 & 0.00 & 0.00 & 0.00 & 0.00 & 0.00 & 0.09 & 0.00 & 0.00 & 0.00 \\
\hline 27 & 0.00 & 0.00 & 0.00 & 0.00 & 0.00 & 0.00 & 0.00 & 0.00 & 0.00 & 0.69 & 0.00 & 0.00 \\
\hline 28 & 0.00 & 0.00 & 0.00 & 0.00 & 0.23 & 0.00 & 0.00 & 0.00 & 0.88 & 0.00 & 0.00 & 0.00 \\
\hline 29 & 0.00 & 0.00 & 0.00 & 0.00 & 0.00 & 0.00 & 0.00 & 0.00 & 0.45 & 0.00 & 0.00 & 0.00 \\
\hline 30 & 0.00 & 0.00 & 0.00 & 0.00 & --- & 0.00 & 0.00 & 0.00 & 0.00 & 0.00 & 0.00 & 0.02 \\
\hline 31 & 0.00 & --- & 0.00 & 0.00 & --- & 0.00 & --- & 0.00 & --- & 0.00 & 0.00 & --- \\
\hline TOTAL & 1.39 & 1.06 & 0.22 & 0.32 & 1.80 & 0.97 & 2.84 & 0.00 & 1.56 & 2.03 & 1.88 & 0.94 \\
\hline MAX & 0.93 & 0.56 & 0.21 & 0.15 & 0.91 & 0.72 & 1.50 & 0.00 & 0.88 & 0.69 & 1.48 & 0.53 \\
\hline MIN & 0.00 & 0.00 & 0.00 & 0.00 & 0.00 & 0.00 & 0.00 & 0.00 & 0.00 & 0.00 & 0.00 & 0.00 \\
\hline
\end{tabular}




\section{0, USGS OFFICE RAIN GAGE AT ALBUQUERQUE, NEW MEXICO \\ STATION ANALYSIS \\ WATER YEAR 2004}

Location.--35 $07^{\prime} 48^{\prime \prime} \mathrm{N}, 106^{\circ} 34^{\prime} 58^{\prime \prime} \mathrm{W}$. The rain gage is located in northeast Albuquerque on the roof of the IRS Building. This building houses the USGS and is just southeast of the intersection of San Mateo and Montgomery Boulevards.

Equipment.--Onset Corporation HOBO Event data recorder and 6.5-inch-diameter tipping bucket. The bucket tips one time per 0.01 inch of rain, and the recorder stores data at 5-minute intervals. Rain gage is calibrated approximately every 2 years and was last calibrated in April 2003.

Record.--The rain gage gave a complete and satisfactory record for the entire water year.

Period of Record.--August 2000 to present.

Remarks.--Record is good for the entire water year.

PRECIPITATION, TOTAL, INCHES, WATER YEAR OCTOBER 2003 TO SEPTEMBER 2004 DAILY SUM VALUES

\begin{tabular}{|c|c|c|c|c|c|c|c|c|c|c|c|c|}
\hline DAY & ОСт & NOV & DEC & JAN & FEB & MAR & APR & MAY & JUN & JUL & AUG & SEP \\
\hline 1 & 0.00 & 0.00 & 0.00 & 0.00 & 0.01 & 0.00 & 0.00 & 0.00 & 0.00 & 0.00 & 0.00 & 0.00 \\
\hline 2 & 0.00 & 0.00 & 0.00 & 0.00 & 0.00 & 0.14 & 0.29 & 0.00 & 0.00 & 0.00 & 0.16 & 0.00 \\
\hline 3 & 0.11 & 0.00 & 0.00 & 0.00 & 0.02 & 0.01 & 0.92 & 0.00 & 0.01 & 0.00 & 0.00 & 0.00 \\
\hline 4 & 0.02 & 0.00 & 0.00 & 0.00 & 0.02 & 0.67 & 0.15 & 0.00 & 0.00 & 0.00 & 0.28 & 0.05 \\
\hline 5 & 0.00 & 0.00 & 0.00 & 0.00 & 0.00 & 0.09 & 0.00 & 0.00 & 0.00 & 0.00 & 0.00 & 0.01 \\
\hline 6 & 0.00 & 0.00 & 0.00 & 0.00 & 0.00 & 0.00 & 0.00 & 0.00 & 0.00 & 0.00 & 0.00 & 0.00 \\
\hline 7 & 0.66 & 0.00 & 0.00 & 0.00 & 0.00 & 0.00 & 0.00 & 0.00 & 0.00 & 0.00 & 0.00 & 0.00 \\
\hline 8 & 0.18 & 0.00 & 0.03 & 0.00 & 0.00 & 0.00 & 0.23 & 0.00 & 0.00 & 0.00 & 0.00 & 0.00 \\
\hline 9 & 0.00 & 0.00 & 0.00 & 0.00 & 0.00 & 0.00 & 0.04 & 0.00 & 0.00 & 0.00 & 0.00 & 0.00 \\
\hline 10 & 0.22 & 0.00 & 0.00 & 0.00 & 0.00 & 0.00 & 0.30 & 0.00 & 0.00 & 0.00 & 0.27 & 0.00 \\
\hline 11 & 0.01 & 0.00 & 0.00 & 0.00 & 0.00 & 0.00 & 0.00 & 0.00 & 0.00 & 0.26 & 0.00 & 0.00 \\
\hline 12 & 0.00 & 0.62 & 0.13 & 0.00 & 0.00 & 0.00 & 0.00 & 0.00 & 0.00 & 0.76 & 0.00 & 0.00 \\
\hline 13 & 0.00 & 0.24 & 0.00 & 0.00 & 0.00 & 0.00 & 0.00 & 0.00 & 0.00 & 0.01 & 0.00 & 0.00 \\
\hline 14 & 0.00 & 0.00 & 0.00 & 0.00 & 0.00 & 0.00 & 0.00 & 0.00 & 0.00 & 0.00 & 0.00 & 0.00 \\
\hline 15 & 0.00 & 0.00 & 0.00 & 0.03 & 0.00 & 0.00 & 0.00 & 0.00 & 0.00 & 0.10 & 0.00 & 0.00 \\
\hline 16 & 0.00 & 0.00 & 0.00 & 0.02 & 0.00 & 0.00 & 0.00 & 0.00 & 0.00 & 0.00 & 0.00 & 0.00 \\
\hline 17 & 0.00 & 0.03 & 0.00 & 0.00 & 0.00 & 0.00 & 0.01 & 0.00 & 0.00 & 0.00 & 0.00 & 0.00 \\
\hline 18 & 0.00 & 0.01 & 0.00 & 0.00 & 0.00 & 0.00 & 0.00 & 0.00 & 0.00 & 0.02 & 0.01 & 0.06 \\
\hline 19 & 0.00 & 0.00 & 0.00 & 0.00 & 0.00 & 0.00 & 0.00 & 0.00 & 0.00 & 0.00 & 0.13 & 0.74 \\
\hline 20 & 0.00 & 0.00 & 0.00 & 0.08 & 0.00 & 0.00 & 0.00 & 0.00 & 0.00 & 0.06 & 0.00 & 0.02 \\
\hline 21 & 0.00 & 0.00 & 0.00 & 0.01 & 0.05 & 0.00 & 0.00 & 0.00 & 0.00 & 0.01 & 0.02 & 0.00 \\
\hline 22 & 0.00 & 0.00 & 0.00 & 0.00 & 0.00 & 0.00 & 0.00 & 0.00 & 0.00 & 0.00 & 0.00 & 0.00 \\
\hline 23 & 0.00 & 0.00 & 0.00 & 0.00 & 0.74 & 0.04 & 0.00 & 0.00 & 0.00 & 0.74 & 0.00 & 0.00 \\
\hline 24 & 0.00 & 0.00 & 0.00 & 0.00 & 0.29 & 0.00 & 0.00 & 0.00 & 0.00 & 0.15 & 0.00 & 0.00 \\
\hline 25 & 0.00 & 0.00 & 0.00 & 0.04 & 0.01 & 0.00 & 0.00 & 0.00 & 0.00 & 0.29 & 0.00 & 0.00 \\
\hline 26 & 0.00 & 0.00 & 0.00 & 0.00 & 0.00 & 0.00 & 0.00 & 0.00 & 0.21 & 0.00 & 0.00 & 0.00 \\
\hline 27 & 0.00 & 0.00 & 0.00 & 0.00 & 0.00 & 0.00 & 0.00 & 0.00 & 0.00 & 0.70 & 0.00 & 0.00 \\
\hline 28 & 0.00 & 0.00 & 0.00 & 0.00 & 0.14 & 0.00 & 0.00 & 0.00 & 0.00 & 0.03 & 0.00 & 0.00 \\
\hline 29 & 0.00 & 0.00 & 0.00 & 0.00 & 0.00 & 0.00 & 0.01 & 0.00 & 0.52 & 0.00 & 0.00 & 0.11 \\
\hline 30 & 0.00 & 0.00 & 0.00 & 0.00 & --- & 0.00 & 0.00 & 0.00 & 0.01 & 0.00 & 0.00 & 0.01 \\
\hline 31 & 0.00 & --- & 0.00 & 0.00 & --- & 0.00 & --- & 0.00 & --- & 0.00 & 0.00 & --- \\
\hline TOTAL & 1.20 & 0.90 & 0.16 & 0.18 & 1.28 & 0.95 & 1.95 & 0.00 & 0.75 & 3.13 & 0.87 & 1.00 \\
\hline MAX & 0.66 & 0.62 & 0.13 & 0.08 & 0.74 & 0.67 & 0.92 & 0.00 & 0.52 & 0.76 & 0.28 & 0.74 \\
\hline MIN & 0.00 & 0.00 & 0.00 & 0.00 & 0.00 & 0.00 & 0.00 & 0.00 & 0.00 & 0.00 & 0.00 & 0.00 \\
\hline
\end{tabular}




\section{0, WALKER PUMP STATION RAIN GAGE AT ALBUQUERQUE, NEW MEXICO STATION ANALYSIS \\ WATER YEAR 2004}

Location.--35 $10^{\prime} 23^{\prime \prime} \mathrm{N}, 106^{\circ} 31^{\prime} 39^{\prime \prime} \mathrm{W}$. The rain gage is located in far northeast Albuquerque near the intersection of Paseo del Norte and Eubank Boulevard.

Equipment.--Onset Corporation HOBO Event data recorder and 6.5-inch-diameter tipping bucket. The bucket tips one time per 0.01 inch of rain, and the recorder stores data at 5-minute intervals. Rain gage is calibrated approximately every 2 years and was last calibrated in March 2003.

Record.--The rain gage gave a complete and satisfactory record for the entire water year except for January 18 to 27; during this period the data recorder lost power. Estimated daily totals for these days are averages of daily totals from the Elena Gallegos, La Cueva, North Camino Arroyo, and Tanoan rain gages.

Period of Record.--May 2002 to present.

Remarks.--Record is good for the entire water year including days estimated as zero; other estimates are poor.

PRECIPITATION, TOTAL, INCHES, WATER YEAR OCTOBER 2003 TO SEPTEMBER 2004 DAILY SUM VALUES

\begin{tabular}{|c|c|c|c|c|c|c|c|c|c|c|c|c|}
\hline DAY & ОСт & NOV & DEC & JAN & FEB & MAR & APR & MAY & JUN & JUL & AUG & SEP \\
\hline 1 & 0.02 & 0.01 & 0.00 & 0.00 & 0.02 & 0.00 & 0.00 & 0.00 & 0.00 & 0.00 & 0.00 & 0.00 \\
\hline 2 & 0.00 & 0.00 & 0.00 & 0.00 & 0.02 & 0.15 & 0.42 & 0.00 & 0.00 & 0.00 & 0.13 & 0.00 \\
\hline 3 & 0.12 & 0.00 & 0.00 & 0.00 & 0.10 & 0.01 & 1.03 & 0.00 & 0.00 & 0.00 & 0.02 & 0.00 \\
\hline 4 & 0.06 & 0.00 & 0.00 & 0.00 & 0.03 & 0.98 & 0.30 & 0.00 & 0.00 & 0.00 & 0.34 & 0.10 \\
\hline 5 & 0.00 & 0.00 & 0.00 & 0.00 & 0.01 & 0.09 & 0.01 & 0.00 & 0.00 & 0.00 & 0.00 & 0.00 \\
\hline 6 & 0.00 & 0.00 & 0.00 & 0.00 & 0.00 & 0.00 & 0.00 & 0.00 & 0.00 & 0.00 & 0.00 & 0.00 \\
\hline 7 & 0.77 & 0.00 & 0.00 & 0.00 & 0.01 & 0.00 & 0.00 & 0.00 & 0.00 & 0.00 & 0.00 & 0.00 \\
\hline 8 & 0.24 & 0.00 & 0.01 & 0.00 & 0.00 & 0.00 & 0.51 & 0.00 & 0.00 & 0.00 & 0.00 & 0.00 \\
\hline 9 & 0.00 & 0.00 & 0.02 & 0.00 & 0.00 & 0.00 & 0.21 & 0.00 & 0.00 & 0.00 & 0.00 & 0.00 \\
\hline 10 & 0.09 & 0.01 & 0.00 & 0.00 & 0.00 & 0.00 & 0.30 & 0.00 & 0.00 & 0.00 & 0.01 & 0.00 \\
\hline 11 & 0.01 & 0.00 & 0.00 & 0.00 & 0.00 & 0.00 & 0.00 & 0.00 & 0.00 & 0.23 & 0.02 & 0.00 \\
\hline 12 & 0.00 & 0.64 & 0.14 & 0.00 & 0.00 & 0.00 & 0.02 & 0.00 & 0.00 & 1.05 & 0.02 & 0.00 \\
\hline 13 & 0.00 & 0.27 & 0.01 & 0.00 & 0.02 & 0.00 & 0.00 & 0.00 & 0.00 & 0.00 & 0.00 & 0.00 \\
\hline 14 & 0.00 & 0.01 & 0.00 & 0.00 & 0.00 & 0.00 & 0.00 & 0.00 & 0.00 & 0.00 & 0.04 & 0.00 \\
\hline 15 & 0.00 & 0.02 & 0.00 & 0.07 & 0.00 & 0.00 & 0.00 & 0.00 & 0.00 & 0.01 & 0.00 & 0.00 \\
\hline 16 & 0.00 & 0.01 & 0.00 & 0.01 & 0.00 & 0.00 & 0.00 & 0.00 & 0.00 & 0.00 & 0.00 & 0.00 \\
\hline 17 & 0.00 & 0.03 & 0.00 & 0.02 & 0.00 & 0.00 & 0.00 & 0.00 & 0.00 & 0.00 & 0.00 & 0.00 \\
\hline 18 & 0.00 & 0.00 & 0.00 & e0.00 & 0.00 & 0.00 & 0.00 & 0.00 & 0.00 & 0.04 & 0.14 & 0.11 \\
\hline 19 & 0.00 & 0.00 & 0.00 & e0.00 & 0.00 & 0.00 & 0.00 & 0.00 & 0.00 & 0.00 & 0.07 & 1.16 \\
\hline 20 & 0.00 & 0.00 & 0.00 & e 0.16 & 0.00 & 0.00 & 0.00 & 0.00 & 0.00 & 0.19 & 0.00 & 0.04 \\
\hline 21 & 0.00 & 0.00 & 0.00 & e0.00 & 0.09 & 0.00 & 0.00 & 0.00 & 0.00 & 0.00 & 0.02 & 0.00 \\
\hline 22 & 0.00 & 0.00 & 0.00 & e0.00 & 0.00 & 0.00 & 0.00 & 0.00 & 0.00 & 0.28 & 0.00 & 0.00 \\
\hline 23 & 0.00 & 0.00 & 0.01 & e0.00 & 0.80 & 0.09 & 0.04 & 0.00 & 0.00 & 0.92 & 0.00 & 0.00 \\
\hline 24 & 0.00 & 0.00 & 0.00 & e0.00 & 0.21 & 0.00 & 0.01 & 0.00 & 0.00 & 0.22 & 0.00 & 0.00 \\
\hline 25 & 0.00 & 0.00 & 0.00 & e0.07 & 0.01 & 0.00 & 0.00 & 0.00 & 0.05 & 0.12 & 0.00 & 0.00 \\
\hline 26 & 0.00 & 0.00 & 0.01 & e0.00 & 0.00 & 0.00 & 0.00 & 0.00 & 0.36 & 0.00 & 0.00 & 0.06 \\
\hline 27 & 0.00 & 0.00 & 0.01 & e0.00 & 0.00 & 0.00 & 0.00 & 0.00 & 0.00 & 0.76 & 0.00 & 0.01 \\
\hline 28 & 0.00 & 0.00 & 0.00 & 0.00 & 0.22 & 0.00 & 0.00 & 0.00 & 0.00 & 0.01 & 0.00 & 0.00 \\
\hline 29 & 0.00 & 0.00 & 0.00 & 0.00 & 0.02 & 0.00 & 0.00 & 0.00 & 0.79 & 0.00 & 0.00 & 0.10 \\
\hline 30 & 0.00 & 0.00 & 0.02 & 0.00 & --- & 0.00 & 0.00 & 0.00 & 0.01 & 0.00 & 0.00 & 0.02 \\
\hline 31 & 0.00 & --- & 0.00 & 0.00 & --- & 0.00 & --- & 0.00 & --- & 0.00 & 0.00 & --- \\
\hline TOTAL & 1.31 & 1.00 & 0.23 & 0.33 & 1.56 & 1.32 & 2.85 & 0.00 & 1.21 & 3.83 & 0.81 & 1.60 \\
\hline MAX & 0.77 & 0.64 & 0.14 & 0.16 & 0.80 & 0.98 & 1.03 & 0.00 & 0.79 & 1.05 & 0.34 & 1.16 \\
\hline MIN & 0.00 & 0.00 & 0.00 & 0.00 & 0.00 & 0.00 & 0.00 & 0.00 & 0.00 & 0.00 & 0.00 & 0.00 \\
\hline
\end{tabular}

CAL YR 2003 TOTAL 7.37 MAX 0.77 MIN 0.00 WTR YR 2004 TOTAL 16.05 MAX $1.16 \quad$ MIN 0.00 


\section{0, WASTEWATER TREATMENT PLANT RAIN GAGE AT \\ ALBUQUERQUE, NEW MEXICO \\ STATION ANALYSIS \\ WATER YEAR 2004}

Location.--35 $01^{\prime} 19^{\prime \prime} \mathrm{N}, 106^{\circ} 39^{\prime} 46^{\prime \prime} \mathrm{W}$. The rain gage is located in southwest Albuquerque on the roof of the Water Quality Lab at the wastewater treatment facility. The facility is located south of the intersection of Rio Bravo Boulevard and 2nd Street.

Equipment.--Onset Corporation HOBO Event data recorder and 6.5-inch-diameter tipping bucket. The bucket tips one time per 0.01 inch of rain, and the recorder stores data at 5-minute intervals. Rain gage is calibrated approximately every 2 years and was last calibrated in March 2003.

Record.--The rain gage gave a complete and satisfactory record for the entire water year.

Period of Record.--August 2000 to present.

Remarks.--Record is good for the entire water year.

PRECIPITATION, TOTAL, INCHES, WATER YEAR OCTOBER 2003 TO SEPTEMBER 2004 DAILY SUM VALUES

\begin{tabular}{|c|c|c|c|c|c|c|c|c|c|c|c|c|}
\hline DAY & ОСт & NOV & DEC & JAN & FEB & MAR & APR & MAY & JUN & JUL & AUG & SEP \\
\hline 1 & 0.02 & 0.00 & 0.00 & 0.00 & 0.01 & 0.00 & 0.00 & 0.00 & 0.00 & 0.00 & 0.00 & 0.00 \\
\hline 2 & 0.00 & 0.00 & 0.00 & 0.00 & 0.00 & 0.13 & 0.83 & 0.00 & 0.00 & 0.00 & 0.05 & 0.00 \\
\hline 3 & 0.12 & 0.00 & 0.00 & 0.01 & 0.01 & 0.00 & 1.42 & 0.00 & 0.00 & 0.00 & 0.00 & 0.00 \\
\hline 4 & 0.02 & 0.00 & 0.00 & 0.00 & 0.00 & 0.65 & 0.14 & 0.00 & 0.02 & 0.00 & 0.00 & 0.13 \\
\hline 5 & 0.01 & 0.00 & 0.00 & 0.00 & 0.00 & 0.02 & 0.00 & 0.00 & 0.00 & 0.00 & 0.00 & 0.01 \\
\hline 6 & 0.00 & 0.00 & 0.00 & 0.00 & 0.00 & 0.01 & 0.00 & 0.00 & 0.00 & 0.00 & 0.00 & 0.00 \\
\hline 7 & 0.74 & 0.00 & 0.00 & 0.00 & 0.00 & 0.00 & 0.00 & 0.00 & 0.00 & 0.00 & 0.00 & 0.00 \\
\hline 8 & 0.18 & 0.00 & 0.00 & 0.00 & 0.00 & 0.00 & 0.35 & 0.00 & 0.00 & 0.03 & 0.00 & 0.00 \\
\hline 9 & 0.01 & 0.00 & 0.00 & 0.00 & 0.00 & 0.00 & 0.00 & 0.00 & 0.00 & 0.00 & 0.00 & 0.00 \\
\hline 10 & 0.44 & 0.00 & 0.00 & 0.00 & 0.00 & 0.00 & 0.28 & 0.00 & 0.00 & 0.00 & 0.10 & 0.00 \\
\hline 11 & 0.01 & 0.00 & 0.00 & 0.00 & 0.00 & 0.00 & 0.00 & 0.00 & 0.00 & 0.00 & 0.00 & 0.00 \\
\hline 12 & 0.00 & 0.51 & 0.13 & 0.00 & 0.00 & 0.01 & 0.01 & 0.00 & 0.00 & 0.02 & 0.00 & 0.00 \\
\hline 13 & 0.00 & 0.18 & 0.01 & 0.00 & 0.00 & 0.00 & 0.00 & 0.00 & 0.00 & 0.00 & 0.00 & 0.00 \\
\hline 14 & 0.00 & 0.00 & 0.00 & 0.00 & 0.00 & 0.00 & 0.00 & 0.00 & 0.00 & 0.00 & 0.00 & 0.00 \\
\hline 15 & 0.00 & 0.01 & 0.01 & 0.06 & 0.00 & 0.00 & 0.00 & 0.00 & 0.00 & 0.00 & 0.10 & 0.00 \\
\hline 16 & 0.00 & 0.03 & 0.00 & 0.02 & 0.00 & 0.00 & 0.00 & 0.00 & 0.00 & 0.00 & 0.00 & 0.00 \\
\hline 17 & 0.00 & 0.02 & 0.00 & 0.01 & 0.00 & 0.00 & 0.01 & 0.00 & 0.00 & 0.00 & 0.00 & 0.00 \\
\hline 18 & 0.00 & 0.00 & 0.00 & 0.00 & 0.00 & 0.00 & 0.00 & 0.00 & 0.00 & 0.10 & 0.03 & 0.10 \\
\hline 19 & 0.00 & 0.00 & 0.00 & 0.01 & 0.00 & 0.00 & 0.00 & 0.00 & 0.00 & 0.01 & 0.03 & 0.82 \\
\hline 20 & 0.00 & 0.00 & 0.00 & 0.07 & 0.00 & 0.00 & 0.00 & 0.00 & 0.00 & 0.11 & 0.00 & 0.04 \\
\hline 21 & 0.00 & 0.01 & 0.00 & 0.01 & 0.05 & 0.00 & 0.00 & 0.00 & 0.00 & 0.02 & 0.00 & 0.00 \\
\hline 22 & 0.00 & 0.00 & 0.00 & 0.00 & 0.01 & 0.00 & 0.00 & 0.00 & 0.01 & 0.39 & 0.00 & 0.00 \\
\hline 23 & 0.00 & 0.00 & 0.00 & 0.00 & 0.59 & 0.17 & 0.01 & 0.00 & 0.00 & 0.42 & 0.00 & 0.00 \\
\hline 24 & 0.00 & 0.00 & 0.00 & 0.00 & 0.24 & 0.00 & 0.00 & 0.00 & 0.00 & 0.05 & 0.00 & 0.00 \\
\hline 25 & 0.00 & 0.00 & 0.00 & 0.00 & 0.01 & 0.00 & 0.00 & 0.00 & 0.00 & 0.35 & 0.01 & 0.00 \\
\hline 26 & 0.00 & 0.00 & 0.00 & 0.00 & 0.00 & 0.00 & 0.00 & 0.00 & 0.00 & 0.00 & 0.00 & 0.00 \\
\hline 27 & 0.00 & 0.00 & 0.00 & 0.00 & 0.00 & 0.00 & 0.00 & 0.00 & 0.00 & 0.12 & 0.00 & 0.00 \\
\hline 28 & 0.00 & 0.00 & 0.00 & 0.00 & 0.10 & 0.00 & 0.00 & 0.00 & 0.00 & 0.01 & 0.00 & 0.00 \\
\hline 29 & 0.00 & 0.00 & 0.00 & 0.00 & 0.00 & 0.00 & 0.00 & 0.00 & 0.34 & 0.00 & 0.01 & 0.04 \\
\hline 30 & 0.00 & 0.00 & 0.00 & 0.00 & --- & 0.00 & 0.00 & 0.00 & 0.00 & 0.00 & 0.04 & 0.01 \\
\hline 31 & 0.00 & --- & 0.00 & 0.00 & --- & 0.00 & --- & 0.00 & --- & 0.00 & 0.00 & --- \\
\hline TOTAL & 1.55 & 0.76 & 0.15 & 0.19 & 1.02 & 0.99 & 3.05 & 0.00 & 0.37 & 1.63 & 0.37 & 1.15 \\
\hline MAX & 0.74 & 0.51 & 0.13 & 0.07 & 0.59 & 0.65 & 1.42 & 0.00 & 0.34 & 0.42 & 0.10 & 0.82 \\
\hline MIN & 0.00 & 0.00 & 0.00 & 0.00 & 0.00 & 0.00 & 0.00 & 0.00 & 0.00 & 0.00 & 0.00 & 0.00 \\
\hline
\end{tabular}

CAL YR 2003 TOTAL 6.71 MAX 0.74 MIN 0.00

WTR YR 2004 TOTAL 11.23 MAX 1.42 MIN 0.00 


\section{0, WASTEWATER TREATMENT PLANT RAIN GAGE AT \\ ALBUQUERQUE, NEW MEXICO \\ STATION ANALYSIS \\ WATER YEAR 2004}

Location.--35 $01^{\prime} 19^{\prime \prime} \mathrm{N}, 106^{\circ} 39^{\prime} 46^{\prime \prime} \mathrm{W}$. The rain gage is located in southwest Albuquerque on the roof of the Water Quality Lab at the wastewater treatment facility. The facility is located south of the intersection of Rio Bravo Boulevard and 2nd Street.

Equipment.--Onset Corporation HOBO Event data recorder and 6.5-inch-diameter tipping bucket. The bucket tips one time per 0.01 inch of rain, and the recorder stores data at 5-minute intervals. Rain gage is calibrated approximately every 2 years and was last calibrated in March 2003.

Record.--The rain gage gave a complete and satisfactory record for the entire water year.

Period of Record.--August 2000 to present.

Remarks.--Record is good for the entire water year.

PRECIPITATION, TOTAL, INCHES, WATER YEAR OCTOBER 2003 TO SEPTEMBER 2004 DAILY SUM VALUES

\begin{tabular}{|c|c|c|c|c|c|c|c|c|c|c|c|c|}
\hline DAY & ОСт & NOV & DEC & JAN & FEB & MAR & APR & MAY & JUN & JUL & AUG & SEP \\
\hline 1 & 0.02 & 0.00 & 0.00 & 0.00 & 0.01 & 0.00 & 0.00 & 0.00 & 0.00 & 0.00 & 0.00 & 0.00 \\
\hline 2 & 0.00 & 0.00 & 0.00 & 0.00 & 0.00 & 0.13 & 0.83 & 0.00 & 0.00 & 0.00 & 0.05 & 0.00 \\
\hline 3 & 0.12 & 0.00 & 0.00 & 0.01 & 0.01 & 0.00 & 1.42 & 0.00 & 0.00 & 0.00 & 0.00 & 0.00 \\
\hline 4 & 0.02 & 0.00 & 0.00 & 0.00 & 0.00 & 0.65 & 0.14 & 0.00 & 0.02 & 0.00 & 0.00 & 0.13 \\
\hline 5 & 0.01 & 0.00 & 0.00 & 0.00 & 0.00 & 0.02 & 0.00 & 0.00 & 0.00 & 0.00 & 0.00 & 0.01 \\
\hline 6 & 0.00 & 0.00 & 0.00 & 0.00 & 0.00 & 0.01 & 0.00 & 0.00 & 0.00 & 0.00 & 0.00 & 0.00 \\
\hline 7 & 0.74 & 0.00 & 0.00 & 0.00 & 0.00 & 0.00 & 0.00 & 0.00 & 0.00 & 0.00 & 0.00 & 0.00 \\
\hline 8 & 0.18 & 0.00 & 0.00 & 0.00 & 0.00 & 0.00 & 0.35 & 0.00 & 0.00 & 0.03 & 0.00 & 0.00 \\
\hline 9 & 0.01 & 0.00 & 0.00 & 0.00 & 0.00 & 0.00 & 0.00 & 0.00 & 0.00 & 0.00 & 0.00 & 0.00 \\
\hline 10 & 0.44 & 0.00 & 0.00 & 0.00 & 0.00 & 0.00 & 0.28 & 0.00 & 0.00 & 0.00 & 0.10 & 0.00 \\
\hline 11 & 0.01 & 0.00 & 0.00 & 0.00 & 0.00 & 0.00 & 0.00 & 0.00 & 0.00 & 0.00 & 0.00 & 0.00 \\
\hline 12 & 0.00 & 0.51 & 0.13 & 0.00 & 0.00 & 0.01 & 0.01 & 0.00 & 0.00 & 0.02 & 0.00 & 0.00 \\
\hline 13 & 0.00 & 0.18 & 0.01 & 0.00 & 0.00 & 0.00 & 0.00 & 0.00 & 0.00 & 0.00 & 0.00 & 0.00 \\
\hline 14 & 0.00 & 0.00 & 0.00 & 0.00 & 0.00 & 0.00 & 0.00 & 0.00 & 0.00 & 0.00 & 0.00 & 0.00 \\
\hline 15 & 0.00 & 0.01 & 0.01 & 0.06 & 0.00 & 0.00 & 0.00 & 0.00 & 0.00 & 0.00 & 0.10 & 0.00 \\
\hline 16 & 0.00 & 0.03 & 0.00 & 0.02 & 0.00 & 0.00 & 0.00 & 0.00 & 0.00 & 0.00 & 0.00 & 0.00 \\
\hline 17 & 0.00 & 0.02 & 0.00 & 0.01 & 0.00 & 0.00 & 0.01 & 0.00 & 0.00 & 0.00 & 0.00 & 0.00 \\
\hline 18 & 0.00 & 0.00 & 0.00 & 0.00 & 0.00 & 0.00 & 0.00 & 0.00 & 0.00 & 0.10 & 0.03 & 0.10 \\
\hline 19 & 0.00 & 0.00 & 0.00 & 0.01 & 0.00 & 0.00 & 0.00 & 0.00 & 0.00 & 0.01 & 0.03 & 0.82 \\
\hline 20 & 0.00 & 0.00 & 0.00 & 0.07 & 0.00 & 0.00 & 0.00 & 0.00 & 0.00 & 0.11 & 0.00 & 0.04 \\
\hline 21 & 0.00 & 0.01 & 0.00 & 0.01 & 0.05 & 0.00 & 0.00 & 0.00 & 0.00 & 0.02 & 0.00 & 0.00 \\
\hline 22 & 0.00 & 0.00 & 0.00 & 0.00 & 0.01 & 0.00 & 0.00 & 0.00 & 0.01 & 0.39 & 0.00 & 0.00 \\
\hline 23 & 0.00 & 0.00 & 0.00 & 0.00 & 0.59 & 0.17 & 0.01 & 0.00 & 0.00 & 0.42 & 0.00 & 0.00 \\
\hline 24 & 0.00 & 0.00 & 0.00 & 0.00 & 0.24 & 0.00 & 0.00 & 0.00 & 0.00 & 0.05 & 0.00 & 0.00 \\
\hline 25 & 0.00 & 0.00 & 0.00 & 0.00 & 0.01 & 0.00 & 0.00 & 0.00 & 0.00 & 0.35 & 0.01 & 0.00 \\
\hline 26 & 0.00 & 0.00 & 0.00 & 0.00 & 0.00 & 0.00 & 0.00 & 0.00 & 0.00 & 0.00 & 0.00 & 0.00 \\
\hline 27 & 0.00 & 0.00 & 0.00 & 0.00 & 0.00 & 0.00 & 0.00 & 0.00 & 0.00 & 0.12 & 0.00 & 0.00 \\
\hline 28 & 0.00 & 0.00 & 0.00 & 0.00 & 0.10 & 0.00 & 0.00 & 0.00 & 0.00 & 0.01 & 0.00 & 0.00 \\
\hline 29 & 0.00 & 0.00 & 0.00 & 0.00 & 0.00 & 0.00 & 0.00 & 0.00 & 0.34 & 0.00 & 0.01 & 0.04 \\
\hline 30 & 0.00 & 0.00 & 0.00 & 0.00 & --- & 0.00 & 0.00 & 0.00 & 0.00 & 0.00 & 0.04 & 0.01 \\
\hline 31 & 0.00 & --- & 0.00 & 0.00 & --- & 0.00 & --- & 0.00 & --- & 0.00 & 0.00 & --- \\
\hline TOTAL & 1.55 & 0.76 & 0.15 & 0.19 & 1.02 & 0.99 & 3.05 & 0.00 & 0.37 & 1.63 & 0.37 & 1.15 \\
\hline MAX & 0.74 & 0.51 & 0.13 & 0.07 & 0.59 & 0.65 & 1.42 & 0.00 & 0.34 & 0.42 & 0.10 & 0.82 \\
\hline MIN & 0.00 & 0.00 & 0.00 & 0.00 & 0.00 & 0.00 & 0.00 & 0.00 & 0.00 & 0.00 & 0.00 & 0.00 \\
\hline
\end{tabular}

CAL YR 2003 TOTAL 6.71 MAX 0.74 MIN 0.00

WTR YR 2004 TOTAL 11.23 MAX 1.42 MIN 0.00 